UNIVERSIDADE DE SÃO PAULO

INSTITUTO DE GEOCIÊNCIAS

\title{
A FLORESTA DE ARAUCÁRIA EM MONTE VERDE (MG): HISTÓRIA SEDIMENTOLOGICA, PALINOLÓGICA E ISOTÓPICA DESDE O ÚLTIMO MÁXIMO GLACIAL
}

Eliane de Siqueira

Orientador: Prof. Dr. Paulo César Fonseca Giannini

TESE DE DOUTORAMENTO

Programa de Pós-Graduação em Geoquímica e Geotectônica

SÃO PAULO

2012 


\section{UNIVERSIDADE DE SÃO PAULO \\ INSTITUT,O DE GEOCIÊNCIAS}

\section{"A FLORESTA DE ARAUCÁRIA EM MONTE VERDE (MG): HISTÓRIA SEDIMENTOLOGGICA, PALINOLÓGICA E ISOTÓPICA DESDE O ÚLTIMO MÁXIMO GLACIAL"}

\section{ELIANE DE SIQUEIRA}

Orientador: Prof. Dr. Paulo Cesar Fonseca Giannini

TESE DE DOUTORAMENTO

COMISSÃO JULGADORA

Nome

Presidente: Dr. Paulo César Fonseca Giannini (Orientador)

Titulares: Dra. Paula Garcia Carvalho do Amaral (IO/USP)

Dra. Maira Barberi

(PUC/GO)

Dr. Luiz Carlos Ruiz Pessenda (CENA)

Dra. Ana Maria Góes (GSA/IGc/USP)

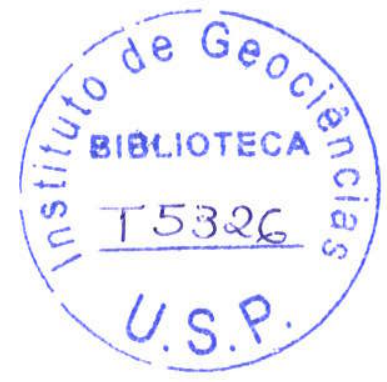

Assinatura
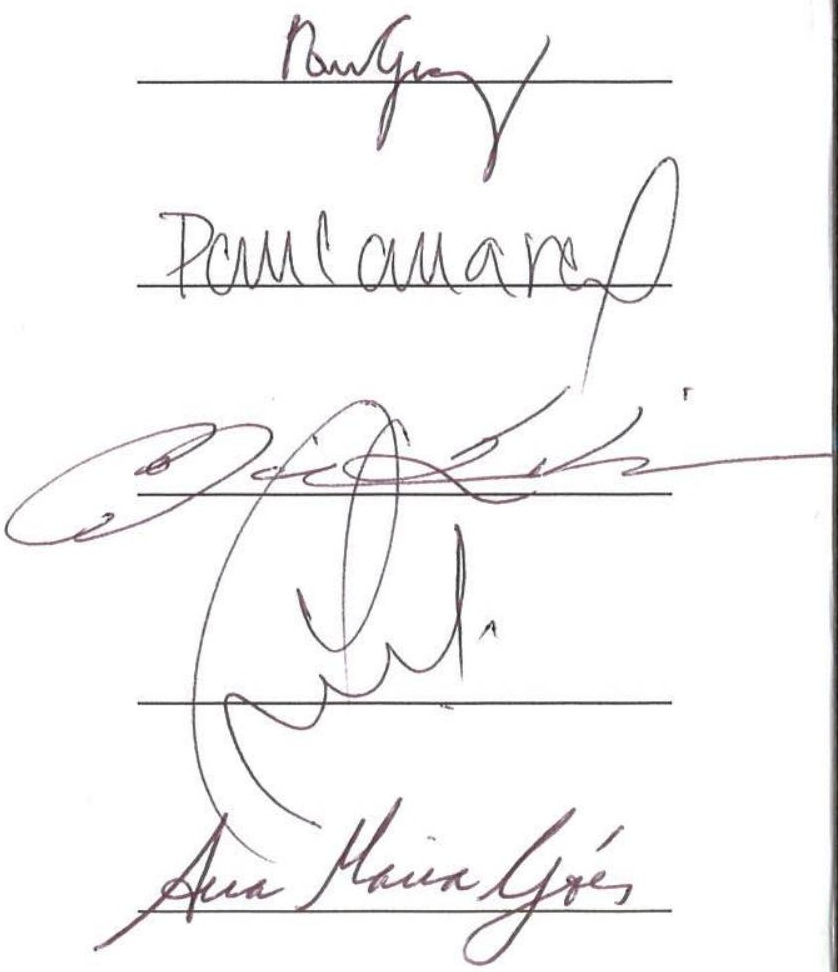


\section{UNIVERSIDADE DE SÃO PAULO INSTITUTOO DE GEOCIÊNCIAS}

\section{A FLORESTA DE ARAUCÁRIA EM MONTE VERDE (MG): HISTÓRIA SEDIMENTOLÓGICA, PALINOLÓGICA E ISOTÓPICA DESDE O ÚLTIMO MÁXIMO GLACIAL}

Eliane de Siqueira

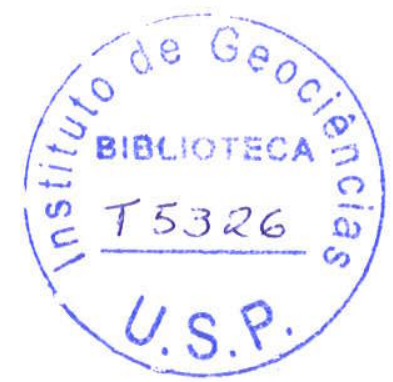

Orientador: Prof. Dr. Paulo César Fonseca Giannini

TESE DE DOUTORAMENTO

Programa de Pós-Graduação em Geoquímica e Geotectônica 
À minha família: meu pai Derval, mãe Eda e irmã Ari... Meu alicerce... Minha vida...

Minha inspiração.

Ao meu esposo Julio Cesar, companheiro, amigo e grande incentivador, real significado do amor incondicional.

Em especial, ao meu príncipe Leonardo, presente de Deus em minha vida, motivo de toda luta...tudo que faço é e sempre será por você filho. 


\section{AGRADECIMENTOS}

Não fazemos nada nesta vida sozinhos e gostaria de manifestar meus sinceros agradecimentos a estas pessoas sem as quais não seria possível concluir esta etapa.

Ao meu orientador Prof ${ }^{\circ}$ Dr. Paulo Cesar Fonseca Giannini, pela extrema competência e paciência nesta orientação. Pela pessoa maravilhosa e pelo profissionalismo admirável, você representou muito mais que um orientador em minha jornada acadêmica. Sempre será um grande exemplo a ser seguido, um grande amigo. Dizer obrigado é muito pouco.

Ao meu co-orientador Profo Dr. Paulo Eduardo de Oliveira, pelas discussões enriquecedoras, apoio palinológico indispensável e incentivo em todos os momentos. Obrigada por sua valiosa amizade.

À minha família, meus amados pais e irmã, a quem devo tudo que sou e alcancei até hoje.

Ao meu amado esposo Julio Cesar, por sua amizade e amor incondicional. Seu incentivo foi à força que precisei e busquei em vários momentos e você sempre esteve lá, parceria para toda vida.

Ao meu amado filho Leonardo, recém chegado neste mundo louco. Em sua inocência, soube sorrir nos momentos em que precisei de força para seguir caminho. Seu olhar foi sempre a inspiração e a luz de todos os meus dias. Como não me canso de dizer: "Filho, você é muito mais do que um dia sonhava ter em minha vida".

A FAPESP, pelo apoio financeiro concedido através do Projeto $n^{\circ}$ 05/51034-6, coordenado pelo Prof ${ }^{\circ}$ Dr. Paulo Cesar Fonseca Giannini. 
A todos os amigos do Laboratório de Geociências da Universidade Guarulhos Dani, Carla, Araci, e a todos os professores pelo apoio direto ou indireto. Em especial, a Andreia Barbieri Resende, pelos processamentos sedimentológicos e por me socorrer em vários momentos de idas e vindas à USP, e à técnica Patricia Ferreira Rosa Cardoso, pelo auxílio pleno nas etapas palinológicas e tantos outros auxílios; vocês, mais uma vez, mostraram serem grandes amigas. À técnica Rosana Saraiva Fernandes, pelo auxílio na palinologia; ao técnico Ricardo Seiffer Nunes de Paula, pela disposição em auxiliar durante algumas etapas sedimentológicas, além de tantos outros favores que sempre me faz, e ao técnico Fábio da Costa Casado, por sua prestatividade indispensável em tantos momentos.

Um agradecimento mais que especial à Profa Dra. Maria Judite Garcia, da Universidade Guarulhos, que sempre me incentivou em tudo que busquei e conquistei profissionalmente até hoje, e a quem devo muitas de minhas conquistas.

A toda equipe do Laboratório de Sedimentologia (IGc/GSA/USP), em especial aos bolsistas de treinamento técnico da FAPESP Vitor Angelo Paulino de Aguiar e Rodolfo Marinho, pelo pronto atendimento sempre que precisamos, e à técnica Elaine Aparecida da Silva Sinfrônio, pelo processamento sedimentológico nas etapas iniciais da pesquisa.

A toda equipe do Laboratório de Carbono 14- CENA/USP, em especial a Susy Eli Marques Gouveia e ao estagiário Rodrigo, pela hospitalidade e auxílio prestado durante a preparação do material, e ao Profo Dr. Luiz Carlos Ruiz Pessenda, pela coordenação das análises.

Ao amigo Rudney, pela companhia em Piracicaba durante a preparação do material para análises isotópicas.

À Helton Rogério Menezes, do Depto. de Geografia da Faculdade Estadual de Ciências e Letras de Campo Mourão, Paraná, pela confecção dos mapas. 
Ao aluno Tarcisio George de Oliveira, pelo auxilio na coleta de material, acompanhado não só dos meus orientadores como também do meu pai, meu primo Claudio e meu esposo. Esses homens fizeram toda a diferença.

Aos meus colegas de trabalho e equipe gestora das escolas pelas quais passei em especial a todos da EE Juvenal Ramos Barbosa e EPG Celso Furtado, pela compreensão, incentivo e valorização de todo trabalho desenvolvido em prol da educação.

A todos os meus "amigos", antigos e recém chegados, que souberam não só apoiar, admirar e torcer, como também compreender minha ausência em diversos momentos. Não citarei nomes, pois vocês, "meus grandes e verdadeiros amigos" sabem se reconhecer nestas palavras...

Aos professores da Universidade de São Paulo que contribuíram para minha formação, em particular ao Dr. Francisco da Cruz Junior, pelas discussões e sugestões enriquecedoras. $E$ a todos os funcionários da Pós-Graduação do IGc/USP, em especial Ana Paula Cabanal e Magali Poli Fernandes Rizzo.

A Deus, por me conceder a força e coragem que não me deixaram desistir jamais.

"Obrigado, não só pelo que você fez... mas por fazer-me, de alguma forma, sentir que valia a pena". 
"Pode ser que um dia deixemos de nos falar... Mas, enquanto houver amizade, Faremos as pazes de novo.

Pode ser que um dia o tempo passe... Mas, se a amizade permanecer, Um do outro se há de lembrar.

Pode ser que um dia nos afastemos...

Mas, se formos amigos de verdade, A amizade nos reaproximará.

Pode ser que um dia não mais existamos...

Mas, se ainda sobrar amizade, Nasceremos de novo, um para o outro.

Pode ser que um dia tudo acabe... Mas, com a amizade construiremos tudo novamente,

Cada vez de forma diferente. Sendo único e inesquecivel cada momento Que juntos viveremos e nos lembraremos para sempre.

Há duas formas para viver a sua vida: Uma é acreditar que não existe milagre. A outra é acreditar que todas as coisas são um milagre".

Albert Einstein 


\section{RESUMO}

A região de Monte Verde (Camanducaia, MG) está situada a $1500 \mathrm{~m}$ de altitude, na porção sul da serra da Mantiqueira. Alvéolos do relevo serrano, como o entroncamento dos córregos do Cadete e da Minhoca com o rio Jaguari, junto à sua área urbana, propiciaram o acúmulo de sucessões métricas de sedimentos argilo-arenosos em condições favoráveis à formação de material turfoso e à preservação de palinomorfos. Nesta área, o presente estudo reconstitui, a partir da integração dos registros palinológico, sedimentológico (granulometria e minerais pesados) e geoquímico/isotópico ( $\mathrm{C}$ e N) de três testemunhos rasos (até $230 \mathrm{~cm}$ ), a evolução e os possíveis controles sedimentares e paleoclimáticos do cenário paleoflorístico no Quaternário tardio, com especial atenção para a Floresta de Araucária.

O contexto geral registrado nos testemunhos é de planície de inundação fluvial, com cobertura arbórea próxima, e influência variável de fluxos de encosta. $\mathrm{Na}$ parte montante do vale do Cadete, obtiveram-se idades compreendidas entre 38695 - 40522 anos cal A.P., em $220 \mathrm{~cm}$ de profundidade, e $2060-1880$ anos cal A.P., em $5 \mathrm{~cm}$. Na parte inferior da coluna, até cerca de 16000 anos A.P., há indícios de aumento de distalidade para cima. Entre cerca de 16000 e 3500 anos A.P., evidencia-se redução da influência da matéria orgânica de plantas terrestres, em detrimento de algas, possivelmente em momento de abertura relativa da cobertura florestal. Os últimos 3500 anos seriam de restabelecimento da cobertura florestal, possivelmente já nos moldes da existente hoje, com redução gradual do aporte de areia.

Mais a jusante do mesmo vale, as idades ficaram compreendidas entre 26764-26023 anos cal A.P., em $210 \mathrm{~cm}$ de profundidade, e $2350-2150$ anos cal A.P., em $10 \mathrm{~cm}$. A parte inferior do intervalo, mais antiga que 20830-20370 anos cal A.P., é dominada por influência de áreas fontes locais, graníticas. Em 20000 anos A.P., fontes distais, metamórficas, passam a atuar, com aumento da influência de algas. Nos últimos 5000 a 6000 anos A.P., tem-se o readensamento da Floresta de Araucária, com manutenção de brejos, sob condições climáticas frias e úmidas. Os resultados sugerem que as mudanças climáticas nos últimos 40 mil anos em Monte Verde não foram acentuadas a ponto de exercer grande 
impacto florístico e que houve predomínio de Araucaria e elementos associados a essa floresta durante todo intervalo estudado, sob condições climáticas frias e úmidas.

Palavras Chave: Floresta de Araucária, Sedimentologia, Palinologia, Isótopos, Último Maximo Glacial. 


\begin{abstract}
The Monte Verde region (Camanducaia, MG) is located in the southern portion of the Mantiqueira Range, with $1500 \mathrm{~m}$ of elevation. Relief alveoli, as the junction of Cadete and Minhoca creeks with Jaguari River, sited close to the urban area, propitiated the accumulation of metric sucessions of sandy-mud sediments, under conditions favorable to the formation of peat material and preservation of palynomorphs. In this area, the present study integrates palynological, sedimentological (grain size and heavy minerals) and geochemical/isotopic ( $\mathrm{C}$ and N) records of three shallow cores (up to $230 \mathrm{~cm}$ deep) to reconstruct the evolution and possible sedimentary and paleoclimatic controls of the Late Quaternary paleofloristic scenario, with special emphasis in the Araucaria Forest.

The general sedimentary context recorded in the cores is a river floodplain close to tree cover areas, and with variable influence of slope flows. On the upstream Cadete valley, were obtained ages of 38695-40522 cal years BP, at the deep of $220 \mathrm{~cm}$, and $2060-1880$ cal years BP, at $5 \mathrm{~cm}$. From the bottom of the column until about $16000 \mathrm{BP}$, there is evidence of increased distality upwards. The time interval between about 16000 and $3500 \mathrm{yr}$ BP shows a reduction in the influence of organic matter derived from terrestrial plants, to the detriment of algae, possibly in a moment of relative opening of the forest cover. The last 3500 years would be characterized by the restoration of forest cover, possibly similar to the existing today, with gradual reduction of the sand supply.

In the downstream of the same valley, the ages vary from 26,764 to 26,023 cal years BP, at $210 \mathrm{~cm}$ deep, to 2350 to 2150 cal years $B P$, at $10 \mathrm{~cm}$. The lower part of the sedimentary column, older than 20830-20370 AP, is dominated by the influence of local granitic sources areas. In 20000 years BP, distal metamorphic sources begin to act paralel with a increased influence of algae. Over the last 5000-6000 years, a increase of Araucaria Forest is recorded, with maintenance of wetlands under cold and wet climatic conditions. This results suggest that climate changes during the last $40 \mathrm{k}$ years in Monte Verde region were not sufficient to exert great floristic impact. Araucaria and associated forest elements predominated during the whole studied interval, under cold and wet weather conditions.
\end{abstract}

Keywords: Araucaria Forest, Sedimentology, Palynology, Isotopes, Last Glacial Maximum. 


\section{SUMÁRIO}

Resumo -

Abstract - -

Sumário -

1. Introdução-

1.1. Dinâmica climática do Sudeste do Brasil -.._ 3

1.2. Descrição da área de estudo --a-n 5

2. Metas e objetivos - - 9

3. Métodos usuais de inferência paleoclimática-_ 10

3.1. Sintese dos consensos e controvérsias -

3.2. Estudos palinológicos - - 14

3.3. Geoquímica de isótopos da MOS - - 15

3.4. Isótopos de espeleotemas-- 18

3.5. Sedimentologia e sua integração com indicadores bióticos e 20 isotópicos

4. Materiais e Métodos -

4.1. Coleta de Sedimentos- 23

4.2. Métodos de Laboratório -- 27

4.2.1. Descrição do testemunho---_- 27

4.2.2. Amostragem de aliquotas--

4.2.3. Método palinológico - 29

4.2.4. Métodos sedimentológicos - 30

4.2.5. Métodos geoquímicos e isotópicos -.. 32

4.2.6. Datações-- 33

4.2.7. Cálculo de taxas de sedimentação-- 34

4.3. Tratamento dos resultados-a- 34

4.4. Interpretação dos resultados integrados -... 39

5. Resultados -- 40

5.1. Análises de fácies-_- 40

5.2. Datação ---

5.3. Taxas de sedimentação-_- 46

5.4.Palinologia-- 49

5.4.1. Análise quantitativa de palinomorfos - 56

5.5. Granulometria e mineralogia-=-

5.5.1.Testemunho MV1 


\section{INTRODUÇÃO}

O presente estudo tem como proposta reconstituir a história ambiental da Floresta de Araucária, na região de Monte Verde (Camanducaia, MG), através de análises palinológica, sedimentológica e de isótopos estáveis da matéria orgânica sedimentar. A utilização destes diferentes tipos de indicadores constitui oportunidade para entender as possíveis correspondências entre eles, seus mecanismos controladores em comum, e portanto, para calibrar o seu significado, em relação a outros tipos de indicadores paleoclimáticos, como, por exemplo, isótopos estáveis e relação $\mathrm{Ca} / \mathrm{Mg}$ em espeleotemas, aplicados em áreas de contexto climático provavelmente similar. Permite, ao mesmo tempo, obter bases para a revisão crítica e o aprimoramento de modelos climáticos prévios envolvendo o Último Máximo Glacial (UMG) e o Holoceno no Sudeste do Brasil e contribuir para a compreensão da dinâmica das mudanças ambientais em domínios de floresta de altitude, como o da área de estudo.

A presença de vegetação indicativa de condições climáticas pretéritas diferentes das atuais, a qual abrange elementos antárticos, andinos e australianos, ao lado de uma flora campestre com estreitas relações com elementos xerófilos do Brasil Central (Brade, 1956), coloca a região da serra da Mantiqueira em posiçăo de destaque no quadro fitogeográfico do Brasil Sudeste (Modenesi \& Melhem, 1992).

A região de Monte Verde, situada na porção sul desta serra (Figura 2), abriga importantes tipos de vegetação (Floresta de Araucária; Floresta Atlântica Montana, Sub-Montana e Semi-Decídua; Campos de Altitude), cuja distribuição possui forte controle por fatores climáticos (Garcia, 1994). Este fato torna esta região especialmente propícia para a identificação de mudanças de cobertura vegetal ligadas a oscilações paleoclimáticas do Quaternário Tardio.

Encontra-se aí um dos grandes remanescentes da Floresta de Araucária da serra da Mantiqueira. A origem e a evolução desta floresta na área, embora ainda desconhecidas, certamente relacionam-se com grandes mudanças ambientais ligadas a variáveis climáticas, o que justifica a realização de um estudo integrado sedimentológico - micropaleontológico - isotópico para sua interpretação. 
A julgar pela correlação entre registros palinológicos de diferentes regiões, os tipos de vegetação do Brasil tiveram suas áreas de ocorrência alteradas, em resposta às variações climáticas identificadas no Quaternário Tardio (De Oliveira, 1992; Ledru, 1993; Behling, 1996, 1997a, Colinvaux et al. 1996 e De Oliveira et al. $1999 \mathrm{a} / \mathrm{b})$. Associadas às alterações de conteúdo palinológico do registro sedimentar, encontram-se mudanças nos atributos sedimentológicos, como granulometria, teor de matéria orgânica e composição mineralógica, e na taxa de deposição. Estas mudanças sedimentológicas, por sua vez, relacionam-se a alterações de processos deposicionais, em parte possivelmente controladas por transformações no tipo de cobertura vegetal e, por extensão, por oscilações climáticas. Desse modo, tanto a palinologia como a sedimentologia refletem em certo grau o contexto climático, e sua análise integrada permite um panorama interpretativo mais amplo e fundamentado deste contexto.

Deve-se considerar que não somente o clima e a cobertura vegetal controlam os processos deposicionais, mas também a própria dinâmica sedimentar característica do contexto geomorfológico da área. A região de Monte Verde, em vista de sua localização em zona serrana moldada pela neotectônica cenozoica, apresenta influência de fatores morfodinâmicos herdados ou ativos como denudações, recuos de escarpas, encaixes de drenagem e desenvolvimento de pequenos leques aluviais ou cones coluviais, com respectivos rios tronco. A análise deste contexto morfodinâmico, porém, faz por realçar a influência indireta do clima. Em áreas com estas características de relevo acidentado, fluxos de massa podem ser tão importantes quanto fluxos trativos e de material em suspensão, podendo a predominância de um tipo de processo sobre outro, em escala de tempo milenar, depender fortemente da saturação aquosa do solo, do regime de chuvas e da densidade de cobertura vegetal, fatores estes relacionados pelo menos em parte ao clima. Há que se considerar também, porém, as mudanças autogênicas dos sistemas deposicionais envolvidos, por exemplo meandramentos de canais. 


\subsection{Dinâmica climática do Sudeste do Brasil}

A Região Sul-Sudeste é influenciada climaticamente por duas massas de ar principais vindas do Oceano Atlântico, a massa de ar Tropical Atlântica (mTa) e a massa de ar Polar (mPa), bem como pelo Sistema de Monções da América do Sul. A massa Tropical Atlântica forma-se nas áreas marítimas aquecidas do Atlântico Sul, de onde atinge a região litorânea do leste-nordeste do Brasil, sobretudo no primeiro semestre do ano, produzindo instabilidades e ação de alísios de leste (Giannini et al., 2005). A Massa Polar consiste em ar frio procedente do Anticiclone Polar, o qual se desloca para norte com trajetória predominantemente marítima no verão e continental no inverno (Orselli, 1986; Martin et al., 1988, 1997). O Sistema de Monções da América do Sul (SMAS) é responsável pelo transporte, para sul, de umidade oriunda da bacia amazônica (Zhou e Lau, 1998; Gan et al., 2004), esta por sua vez relacionada à Zona de Convergência Intertropical (ZCIT). A extensão do SMAS rumo à costa sudeste do país determina a Zona de Convergência do Atlântico Sul (ZCAS), faixa de nebulosidade e umidade capaz de bloquear a migração de frentes frias, pelo menos em certas épocas do ano (Figura 1).
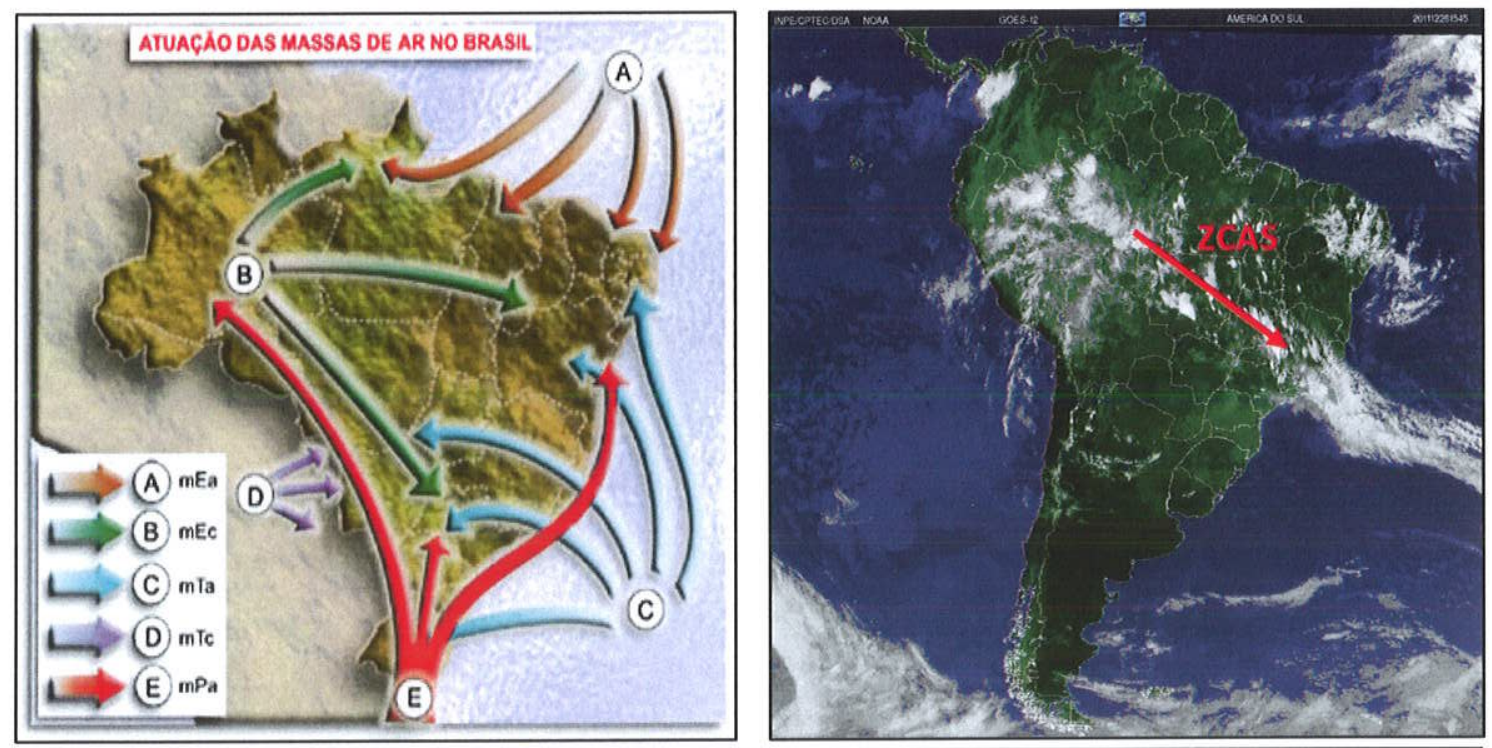

mEa- Massa Equatorial Atlântica; mEc-Massa Equatorial Continental; mTa- Massa Tropical Atlântica; mTc- Massa Tropical Continental; mPa- Massa Polar Atlântica

Figura 1- Principais massas de ar atuantes na América do Sul e a Zona de Convergência do Atlântico Sul (ZCAS).

Fonte: INPE, 2012. 
Segundo Cruz et al. (2007), mais do que aproximadamente $60 \%$ da precipitação média anual da Região Sul-Sudeste entre os estados de Santa Catarina e São Paulo ocorre durante o final da primavera e o verão (outubromarço), ligada ao transporte para sul de umidade pelo SMAS. O restante da precipitação ocorre do final do outono ao início da primavera (abril-setembro) e é geralmente associado com a passagem dos ciclones extratropicais ao longo da costa do Atlântico subtropical (Vera et al., 2002 apud Cruz et al. 2007)

O modelo clássico para a possivel compartimentação ou assimetria climática no território brasileiro é o da sazonalidade climática atual, em que a distribuição de umidade é determinada pelas posições da $\mathrm{ZCl}$ (Zona de Convergência Intertropical), principalmente na Região Norte-Nordeste, e da ZCAS (Zona de Convergência do Atlântico Sul), no Sul-Sudeste. Devido à influência sazonal das monções, de NW, e à trajetória mais oceânica da massa polar, a ZCAS é mais atuante no verão, quando passa a separar duas zonas de pluviosidades contrastadas: chuvosa a sul e seca a norte (Nogués-Paegle \& Mo 2000). A distribuição de chuvas ao longo do ano também é afetada pela posição desta faixa de nebulosidade, resultando mais uniforme (menos sazonal) a sul que a norte (Nimer, 1989).

A posição média da ZCAS exerce influência sobre o fracionamento isotópico do oxigênio na água de chuva, questão fundamental para estudos de paleoclima baseados em espeleotemas (Cruz, 2003, Cruz et al. 2005a, 2007). Assim, a correlação negativa entre quantidade de chuva e $\delta^{18} \mathrm{O}$, observada claramente do Rio de Janeiro para norte, perde intensidade rumo sul, e chega a inverter-se no Rio Grande do Sul. Uma interpretação é que o enriquecimento médio das águas de chuva em $\delta^{18} \mathrm{O}$ a sul do Rio de Janeiro esteja ligado ao aumento da influência de massas de ar úmido polares, carregadas neste isótopo pesado, atuantes especialmente no inverno, em detrimento das monções de verão, enriquecidas no isótopo leve. Desse modo, a variação de $\delta^{18} \mathrm{O}$ ao longo do tempo, num mesmo espeleotema, seria função da proporção entre umidade polar de inverno ( $\delta^{18} \mathrm{O}$ mais positivo) e umidade de monções de verão $\left(\delta^{18} \mathrm{O}\right.$ mais negativo). Visto que, em grande parte do território brasileiro, a precipitação total é controlada pelas freqüencias e intensidade das monções, $0 \quad \delta^{18} \mathrm{O}$ torna-se também, indiretamente, possivel indicador inverso de pluviosidade. Razões $\mathrm{Sr} / \mathrm{Ca}$ 
e $\mathrm{Mg} / \mathrm{Ca}$ constituem porém indicadores mais seguros da precipitação total em espeleotemas, numa relação de proporcionalidade inversa (Cruz et al. 2005a, 2007). Assim, menores valores de índices $\mathrm{Sr} / \mathrm{Ca}$ e $\mathrm{Mg} / \mathrm{Ca}$ no carbonato correspondem a condições mais úmidas.

De acordo com Cruz et al. (2006), o clima subtropical da América do Sul, a leste de Cordilheira dos Andes, é fortemente influenciado pelas interações entre a circulação tropical e a extratropical e está relacionado ao transporte de calor meridional. A variabilidade da temperatura regional está ligada à intensidade e freqüência das frentes frias extratropicais, associadas a incursões transitórias de ar frio e seco de latitudes médias em regiões subtropicais e tropicais da América do Sul, como documentado por Garreaud $(1999,2000)$, Seluchi e Marengo (2000), Vera e Vigliarolo (2000), Vera et al. (2002) e Marengo et al. (2002) apud Cruz et al. (2006).

\subsection{Descrição da área de estudo}

A região de Monte Verde $\left(22^{\circ} 55^{\prime} \mathrm{S}, 46^{\circ} 02^{\prime} \mathrm{W}\right.$ : Figura 2) pertence ao município de Camanducaia, MG, e possui cerca de 1560 m de elevação.

\section{a) Vegetação}

A região de Monte Verde é hoje naturalmente coberta por Floresta de Araucária, onde os dois elementos arbóreos principais são Araucaria angustifolia e Podocarpus lambertii. Segundo De Oliveira (1992), a distribuição da Floresta de Araucária no Sudeste brasileiro foi negativamente impactada pelo aumento gradual de temperatura durante os últimos $10 \mathrm{mil}$ anos. Para esse autor, a distribuição atual disjunta entre o grande domínio dos pinheirais do Sul do Brasil e as "ilhas" naturais de Araucaria angustifolia nas zonas mais elevadas da serra da Mantiqueira são evidências de uma maior área de ocorrência desse tipo de vegetação durante as épocas glaciais.

Uma das características importantes da Floresta de Araucária da região de Monte Verde é a presença de vários tipos de bambu associados ao substrato arbóreo, como Bambusa sp, e no substrato subarbóreo, onde se encontram espécimes dos gêneros Chusquea e Merostachys. Também é notável a presença 
de representantes arbóreos de Vernonia, diferentemente de outros ecossistemas brasileiros onde esse gênero tem exclusivamente hábito herbáceo.

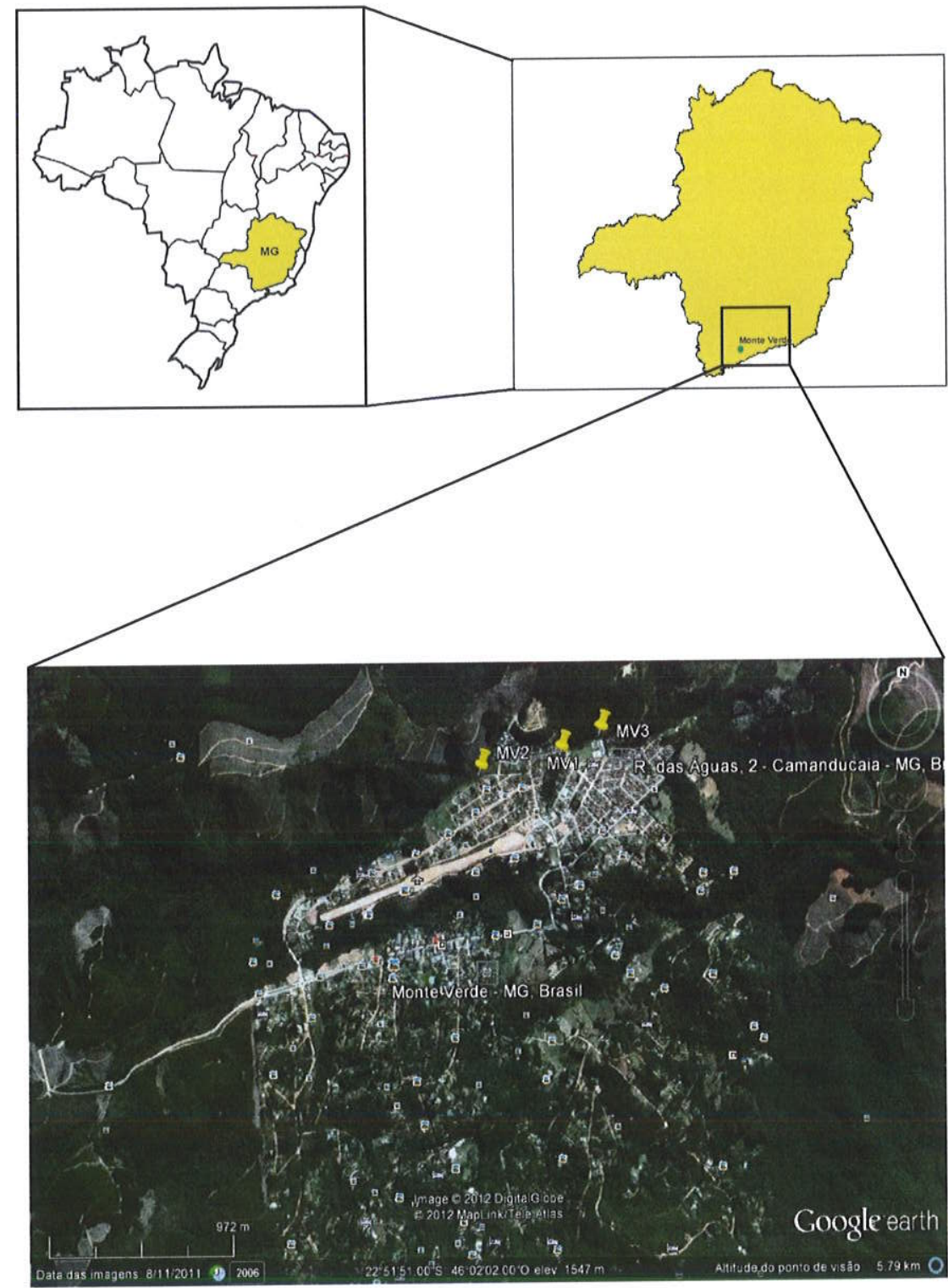

Figura 2- Localização da região de Monte Verde (MG)

Fonte: Google Earth, 2012

\section{b) Geologia}

Geologicamente, a região de Monte Verde é dominada por afloramentos de granitos e granodioritos da Fácies Cantareira e gnaisses e migmatitos do Complexo Paraíba do Sul ou Piracaia (Bistrichi, 2001), todos de idade proterozóica (Figura 3). Do ponto de vista tectono-estrutural, ela encontra-se dentro do bloco delimitado pelas falhas de Camanducaia, a norte, e São Bento, a sul, de orientação geral NE. Estas falhas, pertencentes à Zona de Cisalhamento 
de Jundiuvira, formaram-se no Proterozóico superior, com provável reativação na época (Cretáceo-Paleógeno) de separação dos continentes sul-americano e africano (IPT, 1981). A compartimentação interna do bloco segundo as direções NE e NNE favorece a formação de vales fluviais suspensos encaixados (Saadi, 1993), com tributários orientados segundo N-S ou NW. As confluências destes tributários nos vales principais delimitam alvéolos de relevo, onde a planície de inundação fluvial é mais extensa. É este o caso específico da área urbana de Monte Verde, assentada no entroncamento dos córregos do Cadete e da Minhoca com o rio Jaguari. A planície aluvial na confluência destes três rios constitui a área escolhida para a coleta de testemunhos de sondagem rasa no âmbito desta pesquisa.

Depósitos sedimentares quaternários com elevado teor de finos lutáceos (até mais de $80 \%$ ) e matéria orgânica autóctone (10 a 45\%) já haviam sido previamente reconhecidos e estudados no vale do córrego do Cadete (Siqueira et al. 2003; Siqueira, 2006). Datação preliminar em amostra coletada a $1 \mathrm{~m}$ de profundidade indicou idade correlata à época do UMG $\left(20830-20370\right.$ anos ${ }^{14} \mathrm{C}$ cal A.P.). O presente estudo amplia em profundidade, extensão, quantidade de datações e variedade de indicadores ambientais o trabalho realizado por Siqueira (2006).

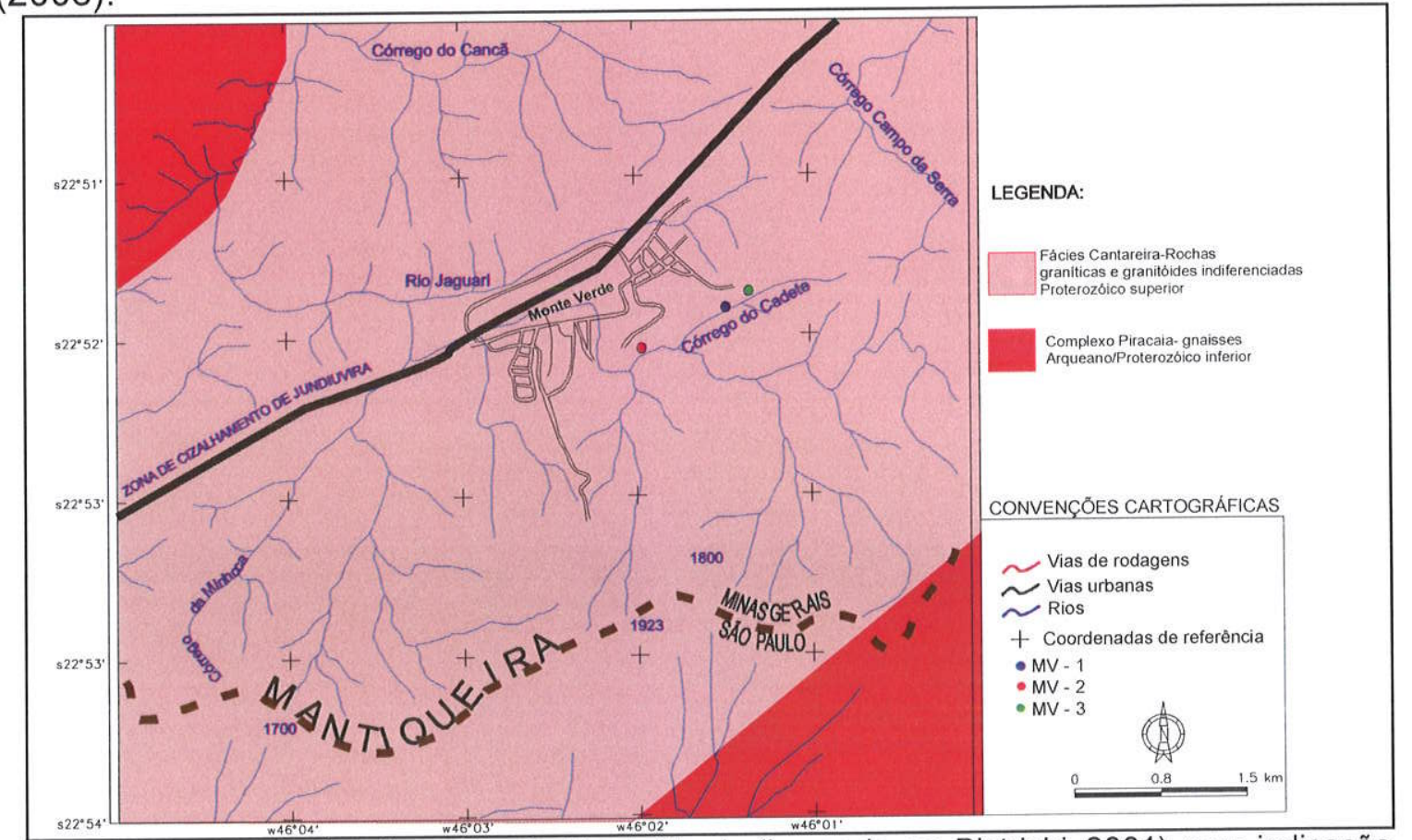

Figura 3- Mapa geológico da região de Monte Verde (baseado em Bistrichi, 2001), com indicação dos pontos de amostragem MV1, MV2 e MV3. 


\section{c) Clima}

Monte Verde possui clima frio afetado diretamente pela altitude, o que permite temperaturas relativamente baixas para sua faixa latitudinal.

Dispõe-se de dados catalogados para a estação Monte Verde, do Instituto Nacional de Meteorologia (Inmet), desde 2004. As temperaturas mínimas registradas no período nessa estação foram de $2^{\circ} \mathrm{C}$, em $20 / 10 / 2010$, e de $0,7^{\circ} \mathrm{C}$, em 15/07/2012 (Figuras 4 e 5).

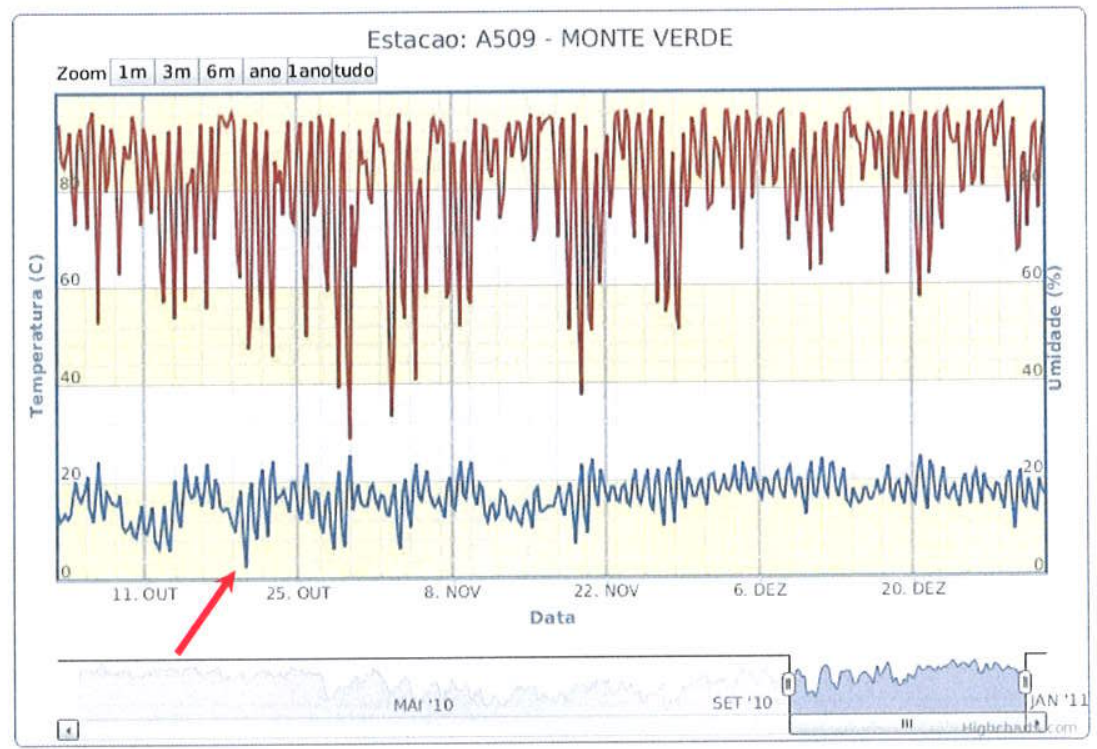

Figura 4- Umidade relativa do ar (curva vermelha) e temperatura (curva azul) registradas na estação meteorológica de Monte Verde, entre outubro e dezembro de 2010, com destaque para a temperatura mínima de $2^{\circ} \mathrm{C}$ em 20/10/2010. Fonte: Inmet, 2012.

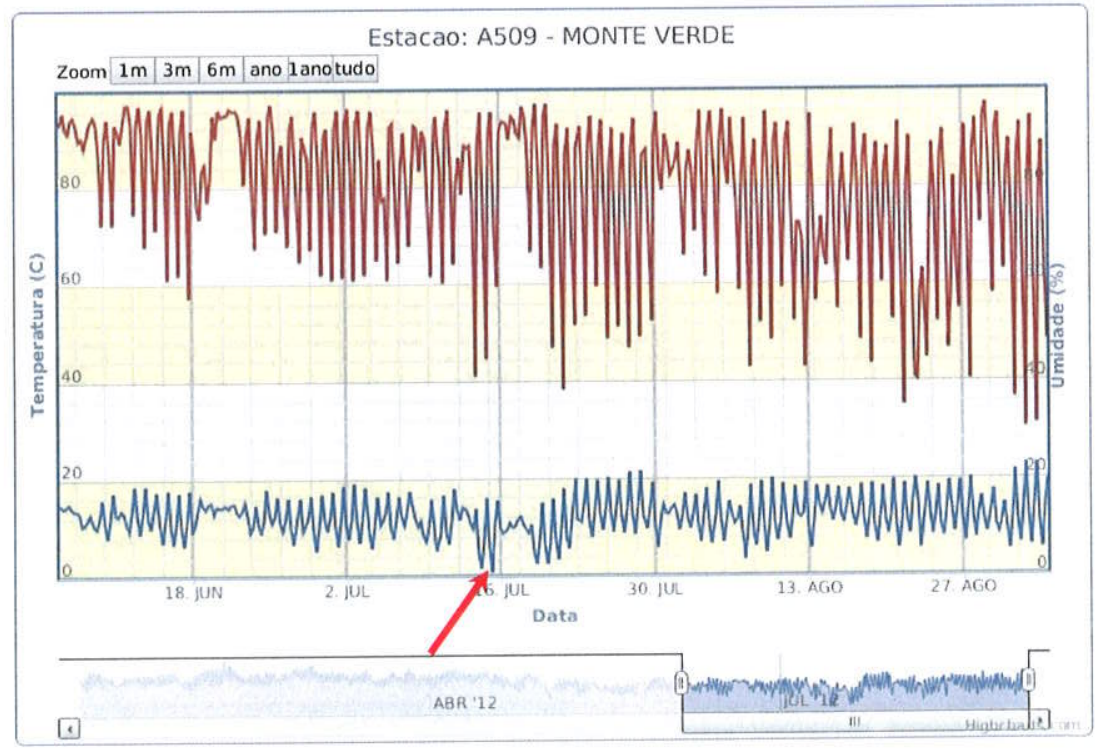

Figura 5- Umidade relativa do ar (curva vermelha) e temperatura (curva azul) registradas na estação meteorológica de Monte Verde, entre junho e setembro de 2012, com destaque para a temperatura mínima de $0,7^{\circ} \mathrm{C}$ em 15/07/2012. Fonte: Inmet, 2012. 


\section{META E OBJETIVOS}

A meta geral desta pesquisa de Doutorado é reconstituir a evolução paleoambiental do Quaternário Tardio na região de Monte Verde (parte sul da serra da Mantiqueira, Minas Gerais), a partir da integração de dados palinológicos, sedimentológicos e de isótopos estáveis da matéria orgânica, e avaliar suas possiveis implicações paleoclimáticas.

Para o alcance desta meta geral, os seguintes objetivos foram estabelecidos:

$\checkmark$ caracterizar a mudança vertical de variáveis sedimentológicas, micropaleontológicas (grãos de pólen e esporos) e geoquímico-isotópicas (relativas a carbono e nitrogênio orgânicos) em testemunhos rasos;

$\checkmark$ realizar a análise integrada das variáveis sedimentológicas, micropaleontológicas e isotópicas estudadas e avaliar quais destas variáveis refletem com mais fidelidade mudanças paleovegetacionais e de dinâmica sedimentar;

$\checkmark$ inferir a evolução do aporte sedimentar terrigeno e orgânico e das condições geoquimicas de sedimentação;

$\checkmark$ inferir a influência da cobertura vegetal na dinâmica sedimentar (especialmente taxa de aporte ou erosão) e, reciprocamente, os efeitos desta dinâmica no estabelecimento da cobertura vegetal;

$\checkmark$ descrever a evolução da sucessão paleoflorística e associá-la a possiveis mudanças climáticas ocorridas no Quaternário Tardio na região;

$\checkmark$ comparar e correlacionar, no contexto das mudanças climáticas, as variações encontradas nos resultados de análises palinológicas, isotópicas e sedimentológicas;

$\checkmark$ comparar os padrões evolutivos da vegetação encontrados em Monte Verde com outros registros do Sudeste e Sul do Brasil e discutir seu possível significado paleoclimático. 


\section{MÉTODOS USUAIS DE INFERÊNCIA PALEOCLIMÁTICA}

De acordo com Giannini (2007), os estudos paleoclimáticos e paleoambientais que envolvem o Quaternário superior no território brasileiro baseiam-se em seis tipos principais de dados: 1. palinologia de sedimentos lacustres e lagunares, incluindo turfeiras (De Oliveira, 1992; Ferraz-Vicentini, 1993; Ledru, 1993; Roth \& Lorscheitter, 1993; Behling, 1995a, 1997a; Lorscheitter \& Mattozo, 1995; Neves \& Lorscheitter, 1995; Colinvaux et al. 1996; Ledru et al. 1996, 1998, 2001; Ferraz-Vicentini \& Salgado-Labouriau, 1996; De Oliveira et al. 1999; Barberi et al. 2000); 2. isótopos de carbono e/ou nitrogênio contidos na matéria orgânica do solo (Desjardins et al. 1996; Pessenda et al. 1996a, 1996b, 1998a, 1998b, 1998c, 2001b; Freitas et al. 2001; Scheel-Ybert et al. 2003; Ybert et al. 2003) ou em fragmentos de carvão (Soubiès, 1979, 1980, Sanford et al. 1985; Desjardins et al. 1996; Pessenda et al. 1996a; Gouveia et al. 1999; Santos et al. 2000); 3. antracologia (Schell-Ybert et al. 2003); 4. registros isotópicos, geoquímicos e de taxa de crescimento em espeleotemas e tufas carbonáticas (Cruz, 2003; Auler et al. 2004; Wang et al. 2004; Cruz et al. 2005 a,b, 2006 a, b, c; Cristalli 2006, Cruz et al. 2007) 5. registros isotópicos em carapaças de organismos marinhos (Arz et al. 1998, 1999; Angulo et al. 1999; Chiessi et al. 2008); e 6. análise química e sedimentológica de testemunhos da plataforma continental (Mahiques et al. 2008). As três primeiras fontes de dados remetem diretamente a tentativas de reconstituição paleoflorística, e as três últimas, a modelos de circulação atmosférica e oceanográfica. Desta forma, pode-se notar que a Floresta Atlântica, principalmente em sua faixa mais oriental, tem sido raramente contemplada nos estudos paleoflorísticos disponíveis na literartura (Neves \& Lorscheitter, 1995; Behling \& Negrelle, 2001; Ledru et al. 2001; Pessenda et al., 2001b; Ybert et al., 2003).

\subsection{Síntese dos consensos e controvérsias}

Da compilação dos dados disponiveis, e baseando-se também em trabalhos de síntese sobre paleovegetação e paleoclima no Quaternário tardio do Brasil, os capítulos mais consensuais sobre a história da vegetação no território 
brasileiro podem ser assim enumerados (Giannini, 2007): 1. predomínio de temperaturas mais baixas que o atual durante o UMG (De Oliveira, 1992, Colinvaux et al. 1996); 2. oscilações abruptas e acentuadas durante o Tardiglacial, aproximadamente entre 17000 e 11000 anos A.P. (Pessenda et al., 2009, Ledru et al. 2002); 3. elevação da pluviosidade efetiva no Holoceno, evidenciada por expansão da floresta (De Oliveira et al. 1999), com suspeitas de episódio menos úmido no meio do período em parte do território brasileiro, incluindo Regiões Sul e Sudeste, principalmente dentro do intervalo entre 8000 e 3000 anos A.P. (Sifeddine et al. 1991; Ledru et al. 1996, 2001; Barreto 1996; Gouveia et al. 1997; Pessenda et al. 1998a, 1998b, 1998c, 2001a,b; De Oliveira et al. 1999; Freitas et al. 2001). No Nordeste do Brasil, o padrão de variação de umidade dentro do Holoceno seria grosso modo inverso ao do Sul-Sudeste (De Oliveira et al. 1999; Cruz et al. 2005, Cruz, 2007, Cruz, 2009) (Tabela 1).

Tabela 1- Principais estudos paleoambientais para o Quaternário tardio brasileiro, baseados em palinologia, isótopos estáveis da matéria orgânica ou isótopos estáveis em espeleotemas

\begin{tabular}{|l|l|l|}
\hline REGIAOO & \multicolumn{1}{|c|}{ AUTORES INDICADOR } \\
\hline & $>$ Absy et al (1991) & \\
& $>$ De Oliveira \& Curtis (2001) & \\
& $>$ De Oliveira (1996) & \\
& $>$ Colinvaux et al. (1996, 1999 e 2000) & \\
& $>$ Bush et al. (2000) & Palinologia \\
AMAZÔNIA & $>$ Colinvaux \& De Oliveira (1999) & \\
& $>$ Behling et al (1996, 2001 e 2002) & \\
& $>$ Behling et al. (2000) & \\
& $>$ Behling \& Negrelle (2001) & \\
& $>$ Ledru et al (2001) & \\
\hline
\end{tabular}




\begin{tabular}{|c|c|c|}
\hline \multirow[t]{2}{*}{ CERRADO } & $\begin{aligned}> & \text { Ledru (2001 e 2002) e Ledru (1993) } \\
> & \text { De Oliveira (1992) } \\
> & \text { Ferraz Vicentini (1993) } \\
> & \text { Ferraz Vicentini \& Salgado Labouriau } \\
& 1996) \\
> & \text { Barberi (1994, 2000 e 2001) } \\
> & \text { Salgado Labouriau \& Ferraz Vicentini } \\
& (1994), \text { Salgado Labouriau et al. } \\
& (1997,1998) \\
> & \text { Behling (2002) } \\
> & \text { Ratter et al. (1996) }\end{aligned}$ & Palinologia \\
\hline & $>$ Parizzi (1993) e Parizzi et al. (1998) & $\begin{array}{c}\text { Palinologia, Geomorfologia e } \\
\text { Geologia }\end{array}$ \\
\hline \multirow[t]{2}{*}{ CAATINGA } & $\begin{array}{l}>\text { De Oliveira et al. (1999) } \\
>\text { Behling et al. }(2000) \\
>\text { Nascimento }(2008)\end{array}$ & Palinologia \\
\hline & $>$ Santos (2007) & $\begin{array}{c}\text { Palinologia, Morfoestrutura, } \\
\text { Sedimentologia e } \\
\text { Geocronologia }\end{array}$ \\
\hline PANTANAL & $\begin{array}{l}>\text { Bezerra (1999) } \\
>\text { De Oliveira et al. (1999b) }\end{array}$ & Palinologia \\
\hline \multirow{5}{*}{ REGIÃO SUL } & $\begin{array}{l}>\text { Behling }(1995,1997,2002 a) \\
>\text { Bauermann }(2003) \\
>\text { Behling \& Negrele }(2001)\end{array}$ & Palinologia \\
\hline & $>$ Cruz et al. $(2005,2007,2009)$ & Isótopos em Espeleotemas \\
\hline & $>$ Amaral (2008) & $\begin{array}{c}\text { Palinologia, Sedimentologia } \\
\text { e Isótopos da MOS }\end{array}$ \\
\hline & $\begin{array}{l}>\text { Garcia (1994) e Garcia et al. (2004) } \\
>\text { Behling (1995 a) } \\
>\text { Chaves (1997) } \\
>\text { Barros et al. (2000) } \\
>\text { Cruz et al. }(2005,2007,2009)\end{array}$ & Palinologia \\
\hline & $\begin{array}{l}>\text { Amaral et al. (2006) } \\
>\text { Siqueira }(2006)\end{array}$ & Palinologia e Sedimentologia \\
\hline
\end{tabular}




\begin{tabular}{|c|l|c|}
\hline \multirow{4}{*}{$\begin{array}{c}\text { REGIÃO } \\
\text { SUDESTE }\end{array}$} & $\begin{array}{c}\text { Palinologia, Sedimentologia e } \\
\text { Isótopos da MOS }\end{array}$ \\
\cline { 2 - 3 } & $>$ Costa (2000) & Palinologia e Análise de Fácies \\
\cline { 2 - 3 } & $>$ Saia (2000) & Palinologia e Isótopos da MOS \\
\cline { 2 - 3 } & $>$ Vidotto (2008) & $\begin{array}{c}\text { Isótopos da MOS } \\
\end{array}$ \\
\cline { 2 - 3 } & $>$ Pessenda et al. (2009) & Palinologia e Diatomáceas \\
\hline
\end{tabular}

Os dados disponiveis na literatura paleoambiental quaternarista do Brasil têm gerado muitas controvérsias, muitas das quais ainda persistem, devido não somente às distintas características geográficas, geológicas e geomorfológicas das regiões estudadas, mas também a divergências de interpretação de mesmos resultados por diferentes autores. Cabe destacar a existência de duas correntes opostas de interpretação para as condições de umidade durante o UMG: mais úmidas, segundo alguns (Colinvaux et al. 1996, 1999; De Oliveira, 1992; Colinvaux, 1993; Haberle, 1997; Barberi, 2001; Bush et al. 2001, Cruz et al., 2007, Pessenda et al. 2009), versus mais secas, segundo outros (Ledru et al. 1998, 2002; Behling, 1998; Behling \& Negrelle 2001). Consequentemente, o tardiglacial, entre cerca de 17000 e 11000 anos AP, seria caracterizado pela diminuição de umidade para o primeiro grupo de autores, ou de aumento progressivo para o segundo grupo.

Com relação à palinologia, existem duas discordâncias relacionadas ao significado de diferentes espectros palinológicos em termos de umidade. A primeira delas diz respeito ao uso de pólen de gramíneas como indicação de clima relativamente seco. Estudos paleoecológicos evidenciam alterações na capa vegetal de gramíneas de áreas tropicais durante o último ciclo glacial, controladas pela concentração de $\mathrm{CO}_{2}$ atmosférico afetada pelo esfriamento glacial, independentes da precipitação (Jolly \& Haxeltine, 1997; Street-Perrot et al. 1997; Marchant et al. 2002; Boom et al. 2002). Assim, interpretações de paleoclima seco baseadas em curvas de concentração e porcentagem de gramíneas devem ser revistas, à luz da comparação com outros tipos de resultados, como sedimentologia, geoquímica de sedimentos e isótopos estáveis da matéria orgânica e do carbonato de espeleotemas. 
A segunda discordância baseia-se no peso interpretativo dado por alguns palinólogos às ervas das famílias Poaceae (Gramineae), Asteraceae (Compositae) e dos gêneros Borreria e Cuphea. De acordo com Colinvaux et al. (1999) e Bush (2002), o uso da abundância de Poaceae nos registros palinológicos, como indicador de (baixa) paleoprecipitação, pode ser tendencioso quando esse táxon ocorre em abundâncias moderadas. Além disso, muitos estágios de sucessões florísticas são caracterizados pela presença, em vegetação florestal, de grande abundância de bambus, pertencentes à família Poaceae, os quais produzem sinal polínico erroneamente classificado como de vegetação de clima mais seco, ou mesmo árido.

Estes dois problemas implicam restrições também aos modelos interpretativos de isótopos de carbono (item 3.3). Nestes modelos, os valores de $\delta^{13} \mathrm{C}$ indicativos de domínio de plantas do tipo $\mathrm{C} 4$, com destaque para as gramíneas, são geralmente tomados como indicadores de vegetação mais aberta e clima mais seco, o que pode, pelas razões expostas, ser questionável em parte dos casos e não constituir, portanto, regra universal.

\subsection{Estudos palinológicos}

Uma das principais ferramentas para a realização de estudos paleoecológicos é a palinologia, que permite, a partir da análise de espectros de palinomorfos preservados em sedimentos, o estudo qualitativo, quantitativo e estatístico das alterações ocorridas nas comunidades vegetais, e sua possivel correlação com modificações climáticas.

Conforme ressaltado por De Oliveira et al. (2005), o desenvolvimento e a aplicação de técnicas palinológicas em vários registros sedimentares do Quaternário brasileiro, especialmente a partir da década de 1970, permitiram uma melhor compreensão de complexo padrão de alterações em diferentes formações vegetais durante o Quaternário tardio, decorrentes tanto de mudanças climáticas globais quanto de efeitos da ação antrópica.

Durante muito tempo, os registros palinológicos com datações ${ }^{14} \mathrm{C}$ utilizados na reconstituição da paleovegetação brasileira restringiram-se aos trabalhos publicados por Absy (1979), referentes a seções curtas de idade 
holocênica na Amazônia. Posteriormente, a mesma autora estendeu esse registro, de modo mais completo, para além do limite Pleistoceno/Holoceno (Absy et al, 1991)

Nos anos seguintes, os estudos paleoambientais e paleoclimáticos foram ampliados para diversas formações vegetais e/ou regiões do Brasil (Tabela 01).

De Oliveira et al. (2005) afirmam que, apesar da falta de dados paleoecológicos detalhados de algumas formações vegetais existentes no território brasileiro, o cenário paleovegetacional fornecido pela análise palinológica tem proporcionado subsídios para a elucidação de problemas biogeográficos $\mathrm{e}$ para o entendimento das flutuações climáticas, especialmente durante o último ciclo glacial (De Oliveira et al., 2005).

A importância assim demonstrada da palinologia justifica a relevância de suas análises. No entanto, a palinologia torna-se tão mais efetiva na interpretação paleoambiental, quanto melhor contextualizada na geomorfologia da região e mais acompanhada de outros tipos de dados. A aplicação de outras ferramentas de interpretação paleoambiental, em apoio à palinologia, tem se tornado cada vez mais comum, como exemplificado nos trabalhos de Bezerra (1999), Barberi (2001) e Rodrigues et al. (2002). Bezerra (1999) apresentou interpretações paleoambientais para dados palinológicos, isotópicos e sedimentológicos referentes aos sedimentos das lagoas Negra e Castelo, na região de Ladário (MS), Pantanal sul matogrossense. Barberi (2001) realizou análises palinológicas e mineralógicas na Lagoa Bonita (DF) e forneceu evidências de trocas vegetacionais e de alterações climáticas. Rodrigues et al. (2002) basearam-se em estudos geoquímicos, mineralógicos, palinológicos e isotópicos em sedimentos do lago Silvana, em Ipatinga (MG), para registrar mudanças na vegetação e assim inferir as condições climáticas locais, durante o Holoceno, daquele setor da Floresta Atlântica.

\subsection{Geoquímica e isótopos da MOS}

Uma das ferramentas eficazes, e cada vez mais usual, para complementar os estudos palinológicos é a análise total e isotópica de elementos químicos ligados à matéria orgânica sedimentar (MOS), como carbono e nitrogênio. 
A razão carbono-nitrogênio ou $\mathrm{C} / \mathrm{N}$ (em seus valores totais, não isotópicos) é uma análise da composição química geralmente aplicada a solos e sedimentos, e que visa obter a origem da matéria orgânica neles dispersa (Bruland et al. 1989).

Nestes estudos, parte-se do princípio de que organismos vegetais pertencentes a meios com condições físico-químicas particulares de salinidade, $\mathrm{pH}$ e saturação líquida, por exemplo, possuem razões $\mathrm{C} / \mathrm{N}$ com ordem de valores também peculiares. De fato, razões entre 5 e 10 são indiscutivelmente ligadas à matéria orgânica de origem algácea, enquanto valores acima de 20 relacionam-se a matéria orgânica de plantas vasculares terrestres (isto é, não aquáticas). Esta diferença é o reflexo de dois fatores: (1) a ausência de celulose nas algas, em contraposição a sua abundância nas plantas vasculares; e (2) a riqueza em proteínas na matéria orgânica de origem algácea (Meyers, 1994; Amaral, 2008).

Entretanto, a diagênese pode modificar a composição elementar da matéria orgânica e, conseqüentemente, os valores de razão $\mathrm{C} / \mathrm{N}$ (Meyers \& Lallier-Vergès, 1999). A degradação parcial da matéria orgânica de origem algácea durante o soterramento pode diminuir seletivamente os componentes protéicos e assim aumentar a razão $\mathrm{C} / \mathrm{N}$. O inverso, diminuições nos valores de $\mathrm{C} / \mathrm{N}$, pôde ser observado em sedimentos oceânicos onde a amônia derivada da decomposição da matéria orgânica é adsorvida em minerais de argila (Müler, 1977 apud Meyers, 1997). Contudo, mesmo considerando-se possiveis mudanças na composição elementar da matéria orgânica sedimentar, estas normalmente não são grandes o suficiente para impedir a diferenciação entre a origem a partir de plantas vasculares e a partir de algas (Meyers \& Lallier-Vergès, 1999; Amaral, 2008).

Complementar a esta análise, o uso das razões isotópicas $\delta^{13} \mathrm{C}$ e $\delta^{15} \mathrm{~N}$ na determinação da fonte da matéria orgânica preservada nos sedimentos baseia-se na diferença entre as assinaturas isotópicas de plantas terrestres (plantas tipo C3, C4), algas e material de origem continental versus marinha (Amaral, 2008; Amaral et al., 2011).

De maneira geral, a composição isotópica do carbono na matéria orgânica vegetal reflete a forma como a planta assimila este elemento químico durante a fotossíntese. Plantas terrestres que utilizam o ciclo fotossintético C3 apresentam valores de $\delta^{13} \mathrm{C}$ de $-20 \%$ a $-35 \%$ com média de $-27 \%$, e as que utilizam o ciclo 
C4, valores de $-9 \%$ a $-16 \%$ com média de $-14 \%$ (Meyers, 1997). O fitoplâncton de água doce, que utiliza $\mathrm{O} \mathrm{CO}_{2}$ dissolvido na água, normalmente em equilibrio isotópico com o $\mathrm{CO}_{2}$ atmosférico, apresenta valores de $\delta^{13} \mathrm{C}$ entre $-25 \%$ e $-30 \%$, assinatura isotópica que não permite sua distinção em relação a plantas terrestres C3. O fitoplâncton marinho, que utiliza como fonte de carbono inorgânico o bicarbonato dissolvido, apresenta valores de $\delta^{13} \mathrm{C}$ entre -19 e $-22 \%$ (Emerson \& Hedges, 1988). Já a utilização do $\delta^{15} \mathrm{~N}$ na identificação da origem da matéria orgânica tem como base a distinção entre a composição isotópica das fontes de nitrogênio inorgânico, diferentes no ambiente aquático e fora dele (Amaral, 2008; Amaral et al., 2011). $O \delta^{15} \mathrm{~N}$ de nitratos dissolvidos na água é entre $7 \%$ e $10 \%$, enquanto $\circ \delta^{15} \mathrm{~N}$ do $\mathrm{N}_{2}$ atmosférico é cerca de $0 \%$. Peterson \& Howarth (1987) demonstraram que esta diferença de valores é preservada no conteúdo isotópico da matéria orgânica produzida pelo plâncton $\left(\delta^{15} \mathrm{~N} \sim 8,6 \%\right.$ ) e por plantas terrestres $\left(\delta^{15} \mathrm{~N} \sim 0,4 \%\right.$ ) , o que torna possivel a distinção entre matéria orgânica derivada de plantas terrestres e de algas.

De acordo com Pessenda et al. (2005), a importância dos estudos geoquímicos e isotópicos de $\mathrm{C}$ e $\mathrm{N}$ está principalmente associada ao fato de que suas técnicas podem ser utilizadas em todas as regiões onde haja vegetação nativa e solos ou sedimentos relativamente espessos, cuja cronologia determinada por ${ }^{14} \mathrm{C}$ represente o período de tempo, dentro do Quaternário, que se quer estudar.

Os isótopos de carbono têm sido aplicados em estudos da dinâmica da MOS, para obter informações sobre as mudanças na vegetação e clima durante o Quaternário tardio (Schwartz et al., 1986; Pessenda et al., 1996a). Essa ferramenta vem sendo usada em diversas áreas do Brasil para documentar mudanças vegetacionais no decorrer do Holoceno (Victoria et al., 1995; Desjardins et al., 1996; Pessenda et al., 1996a, 1996c, 1998b, 1998a, 2001a, 2001b, 2004a, 2004b; Gouveia et al., 1997, 2002), alcançando em alguns casos o Pleistoceno tardio (Freitas et al., 2001; Pessenda et al., 2004a,b; Mofatto, 2005) (Pessenda et al. 2005).

A primeira utilização de isótopos do carbono $\left({ }^{12} \mathrm{C},{ }^{13} \mathrm{C}\right.$ e $\left.{ }^{14} \mathrm{C}\right)$ da MOS em estudos paleoambientais no Brasil foi efetuada nas regiões Sul (Londrina-PR) e Sudeste (Piracicaba-SP) (Pessenda, 1999), onde se encontrou significativa 
influência de plantas $\mathrm{C} 4$ desde o Pleistoceno superior até o Holoceno médio, o que, atribuído a gramíneas, levou à interpretação de clima relativamente seco no período (Pessenda et al., 2005). No Mato Grosso, verificou-se a presença de matéria orgânica antiga, humificada e estável, proveniente de vegetação anterior, parecida com a atualmente presente em campos e cerrados (Lucas et al., 1993 apud Pessenda et al., 2005).

Tentativas de reconstituição paleoclimática utilizando-se de isótopos de carbono nos sedimentos intensificaram-se no Brasil a partir da década de 1990.

Já se dispõe de resultados obtidos em várias regiões do país, que têm sido usados para interpretar trocas de vegetação C3 (florestas) e C4 (vegetação aberta) no passado, até cerca de 50000 anos A.P.. A correlação desses dados permite o estudo e interpretação da dinâmica paleoflorística e climática do Quaternário com alcance regional, desde que apoiada em controle estratigráfico, faciológico e micropaleontológico. Sendo assim, a análise isotópica de C e N torna-se importante técnica complementar à micropaleontologia e à sedimentologia, na reconstrução da vegetação associada às mudanças climáticas do Quaternário (Pessenda et al. 1996b).

\subsection{Isótopos de espeleotemas}

Os espeleotemas são formações sedimentares autóctones, geralmente compostas por aragonita e calcita primárias e/ou por calcita secundária, resultantes da sucessiva dissolução e reprecipitação in situ de carbonato em cavernas. Quando primários e produzidos em equilíbrio com as águas de chuva, são considerados depósitos ideais para o estudo das mudanças paleoclimáticas continentais ao longo de grandes intervalos de tempo (Atkinson et al. 1978; Harmon et al. 1978; Baker et al. 1993 apud Cruz, 2003), já que permitem a obtenção de registros quantitativos químicos e isotópicos contínuos, de alta resolução, para a indicação de mudanças na fonte da umidade e, portanto, na dinâmica climática.

Uma vez demonstrado, através de testes específicos, que a deposição do carbonato ocorreu em equilibrio isotópico com a água de percolação, o espeleotema passa a ser um registro favorável para o estudo paleoclimático, com 
- qual poderão ser obtidas valiosas informações para interpretações paleoambientais, principalmente a partir da geoquímica de isótopos estáveis (Cruz, 2003).

Existe atualmente grande número de trabalhos com registros da variação de $\delta^{18} \mathrm{O}$ e taxas de crescimento em espeleotemas, principalmente em regiões de clima temperado, situadas no hemisfério norte. Alguns destes trabalhos fazem correlações entre dados paleoclimáticos abrangendo áreas geográficas mais amplas (Harmon et al. 1978a; Hennig et al. 1983; Baker et al. 1993). Essas variações ao longo do tempo podem indicar a temperatura ou composição isotópica da precipitação na época de deposição do carbonato. Isso ocorre porque os espeleotemas são depositados de forma lenta e contínua ao longo de todo seu crescimento, o que registra a composição isotópica da água como reflexo de variações climáticas (Thompson et al., 1976; Schwarcz et al., 1976 apud Cruz, 2003).

Por outro lado, a assinatura isotópica de $\delta^{13} \mathrm{C}$ pode ser utilizada como indicador de paleovegetação, pois a água de percolação, ao atravessar o solo, se enriquece em $\mathrm{CO}_{2}$ com características da composição isotópica do carbono da cobertura vegetal e por isso pode refletir a proporção de plantas com metabolismo C3 e C4 (Bar-Matthews \& Ayalon, 1997; Dorale et al., 1998 apud Cruz, 2003).

Os espeleotemas estudados por Cruz et al. (2005) nas cavernas Santana, no Vale do Ribeira, e Botuverá, em Santa Catarina, apresentaram acentuada ciclicidade na variação de $\delta^{18} \mathrm{O}$ no decorrer dos últimos $120 \mathrm{mil}$ anos. Os ciclos encontrados, com duração de aproximadamente 23 mil anos, coincidem com as mudanças orbitais de insolação controladas pela precessão dos equinócios. Valores de $\delta^{18} \mathrm{O}$ mais positivos nos espeleotemas, correlatos a menor precipitação na Região Sul-Sudeste, foram encontrados, por exemplo, cerca de $30 \mathrm{mil}$ anos A.P. e no início do Holoceno, enquanto valores mais negativos, correlatos a maior precipitação na mesma região, registraram-se cerca de 42 mil anos A.P. e na época do UMG. Para os últimos 10000 anos A.P., a tendência encontrada é de valores de $\delta^{18} \mathrm{O}$ cada vez mais negativos, e, portanto, de aumento de umidade. 


\subsection{Sedimentologia e sua integração com indicadores bióticos e isotópicos}

As ferramentas mais tradicionais em inferências paleoclimáticas no Quaternário são a micropaleontologia e os isótopos estáveis da MOS, com especial destaque para a palinologia. A maior parte dos modelos de reconstituição paleoclimática no Brasil baseia-se em interpretação paleoflorísica a partir de dados palinológicos e isotópicos, na maioria das vezes estudados em separado. A correlação do conteúdo micropaleontológico e geoquímico-isotópico com o paleoclima envolve, porém, variáveis ligadas a outras disciplinas, além das estritamente biológicas e climatológicas. Este fato torna conveniente a adoção de enfoques integrados em estudos paleoambientais do Quaternário, com a utilização paralela de outros tipos de indicadores ambientais, entre os quais se destacam aqui os sedimentológicos. Isso porque o tipo de clima controla não somente a distribuição dos organismos, como, ao lado do relevo e da tectônica, o tipo e a intensidade de atuação dos processos intempéricos e erosivos. $E$ estes processos podem ser avaliados através de atributos texturais e mineralógicos dos sedimentos.

A atenção a esses atributos sedimentológicos não é apenas questão de se ter um tipo de indicador paleoambiental a mais, mas também de contemplar fatores controladores do registro que não sejam estrita ou diretamente relacionáveis ao clima. Assim, por exemplo, os fatores regionais que controlam o conteúdo micropaleontológico e geoquímico-isotópico não são apenas paleoclimáticos, mas também relacionados ao nivel relativo do mar e/ou ao nível de base de erosão, dois conceitos que envolvem parâmetros geológicos. Além disso, a interpretação destes controles maiores só pode ser devidamente discutida depois de avaliada a influência de fatores locais sobre a distribuição dos microfósseis e da MOS. E, dentre estes últimos fatores, destacam-se variáveis tipicamente sedimentológicas como origem, volume e constituição do aporte sedimentar e tipos de processos deposicionais (materializados nas fácies), todas com implicações paleogeográficas, paleo-hidrodinâmicas e paleoflorísticas. O tipo de processo deposicional pode, por exemplo, destruir o material polínico, como no caso de intemperismo em condições oxidantes, associadas à precipitação de 
óxidos metálicos, ou da deposição turbulenta em meio a material grosso; ou ajudar na sua preservação, como é o caso de processos deposicionais lentos, com aporte de material fino, em condições redutoras. Por outro lado, o pólen, ao caracterizar a vegetação do local, permite deduzir a presença ou ausência de filtros naturais (florísticos) para o afluxo sedimentar.

Resultados relativos à concentração polínica no sedimento, por exemplo, são fortemente controlados pela taxa de aporte terrígeno. Aumento de aporte terrígeno, favorecido por abertura ou rarefação da cobertura vegetal, pode diluir a concentração polínica. A taxa de aporte terrígeno, por sua vez, depende não só da densidade de cobertura vegetal, mas do comportamento do nível de base e/ou nível do mar, do relevo e da dinâmica erosivo-deposicional. Elevações de nível de base podem provocar afogamentos e inundações em áreas de planície sedimentar, e assim gerar alterações de cobertura floristica confundiveis com as impostas por mudanças de clima (e.g., mais úmido). Alterações autocíclicas de dinâmica sedimentar, em encostas, leques aluviais e planícies fluviais ou costeiras também podem gerar o mesmo tipo de efeito, em escala mais local (Amaral et al., 2006, 2011). Estudos palinológicos-sedimentológicos integrados exigem, portanto, a caracterização do aporte sedimentar, tanto em termos quantitativos como qualitativos.

A caracterização quantitativa do aporte corresponde à determinação da taxa de sedimentação por meio da relação entre idade e espessura de cada intervalo vertical amostrado, o que pressupõe a realização sistemática de datações. A caracterização qualitativa do aporte diz respeito à avaliação da influência terrígena versus biodetrítica, ou mesmo autóctone, via parâmetros geoquímico-isotópicos, como teores de $\mathrm{C}$ e $\mathrm{O}$ orgânicos, e à inferência da dinâmica deposicional, via análise de fácies. As fácies são unidades sedimentares concretas e descritivas, porém desconfinadas estratigraficamente (Walker, 1976; Anderton, 1985), delimitadas com base em mudanças de uma ou mais dentre cinco propriedades macroscópicas: geometria externa, estruturas, paleocorrentes, granulação e fósseis. As associações laterais e sucessões verticais de fácies são imprescindíveis para a compreensão e reconstrução do contexto e da evolução paleogeográfica local. Em estudos palinológicos de depósitos quaternários, é freqüente a base de dados provir de testemunhos em sedimentos argilosos ou 
turfáceos maciços, o que reduz as possibilidades de se trabalhar com estruturas sedimentares. Conseqüentemente, a caracterização dos padrões de variação da distribuição granulométrica e de suas medidas estatísticas (média, desvio padrão, assimetria, curtose), seguida, em caso de detalhamento, pelo exame da variação de composição mineralógica, passa a ter relevância redobrada na distinção de fácies.

A análise de minerais pesados pode ser útil em estudos de reconstituição ambiental no Quaternário. Variações nas assembleias de minerais pesados ao longo do registro sedimentar possuem possível significado quanto a mudanças não só de hidrodinâmica, geralmente ligadas intimamente aos processos e fácies deposicionais, mas também de proveniência e dissolução pós-deposicional. Estes três fatores são capazes de controlar também, direta ou indiretamente, o conteúdo polínico. A adequada avaliação do grau de influência de cada um deles depende de que a quantificação de minerais pesados seja idealmente acompanhada de estudos de índices mineralógicos (e.g. índices de Morton \& Hallsworth (1994, 1999): ver item 4.3) ou, alternativamente, de textura superficial (potenciais indicadores de dissolução e desgaste físico) e grau de arredondamento (índice de grau de retrabalhamento mecânico).

Deve-se considerar ainda que a abundância e distribuição vertical de microfósseis são passiveis de modificações pós-deposicionais geradas por dissolução eodiagenética, incluindo a ligada a pedogênese, identificáveis, por exemplo, pela quantificação e/ou exame de textura superficial de minerais pesados na fração areia. 


\section{MATERIAIS E MÉTODOS}

\subsection{Coleta de sedimentos}

Foram coletadas três colunas sedimentares: MV1 (coordenadas

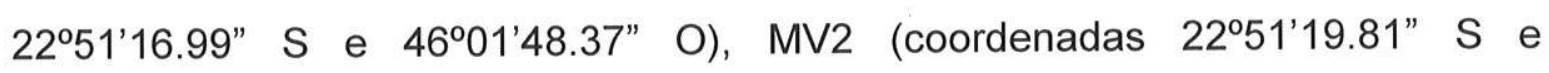

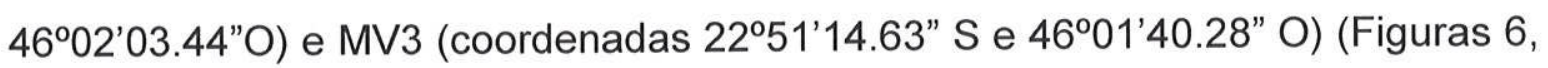
7 e 8). O procedimento de coleta adotado fundamentou-se na utilização do equipamento vibrocorer (vibro-amostrador), que permite a retirada de testemunhos contínuos e sem deformação (Martin et al., 1995).

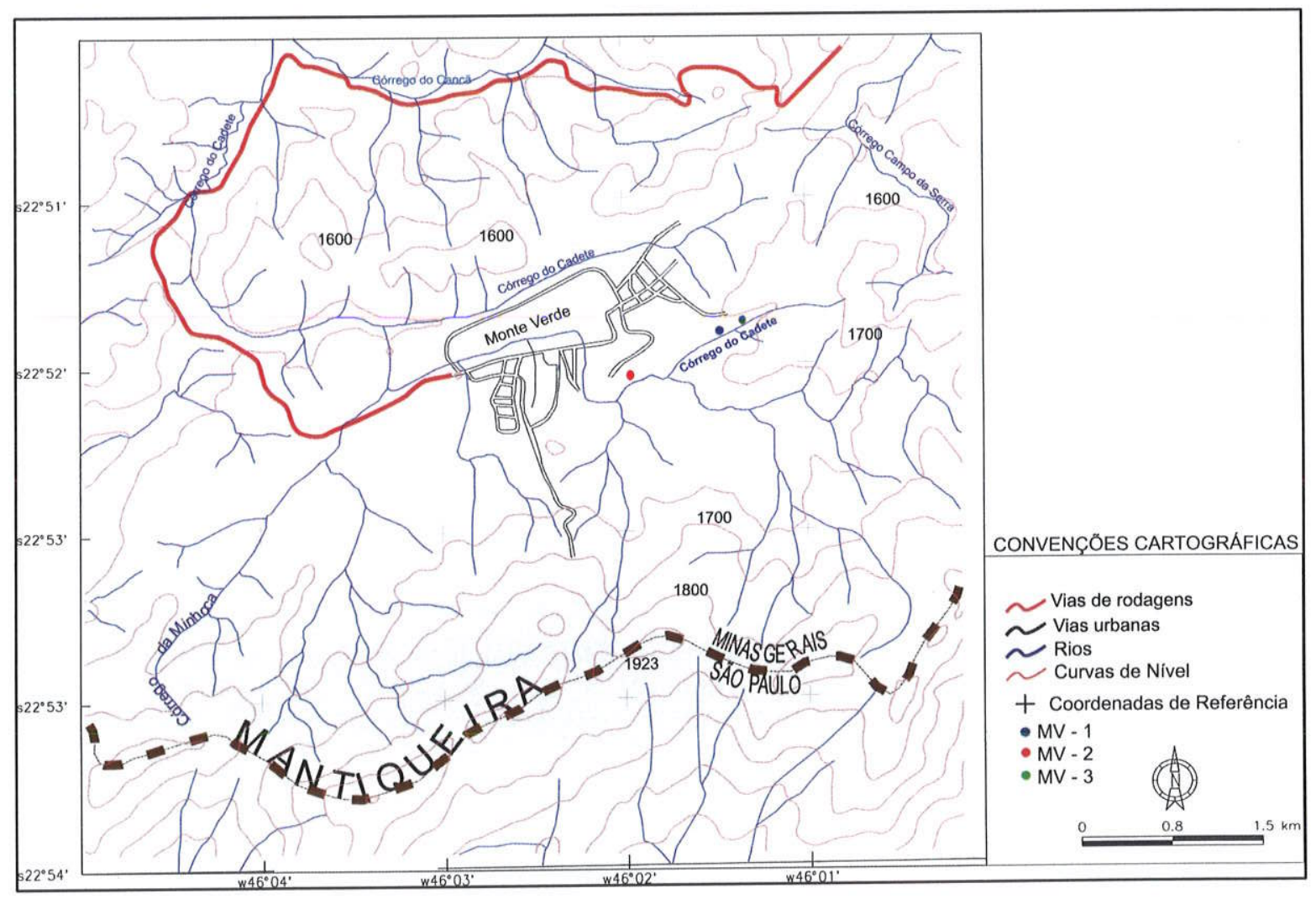

Figura 6- Mapa topográfico da região de Monte Verde (baseado em Bistrichi, 2001) com os pontos de coleta de material sedimentar 


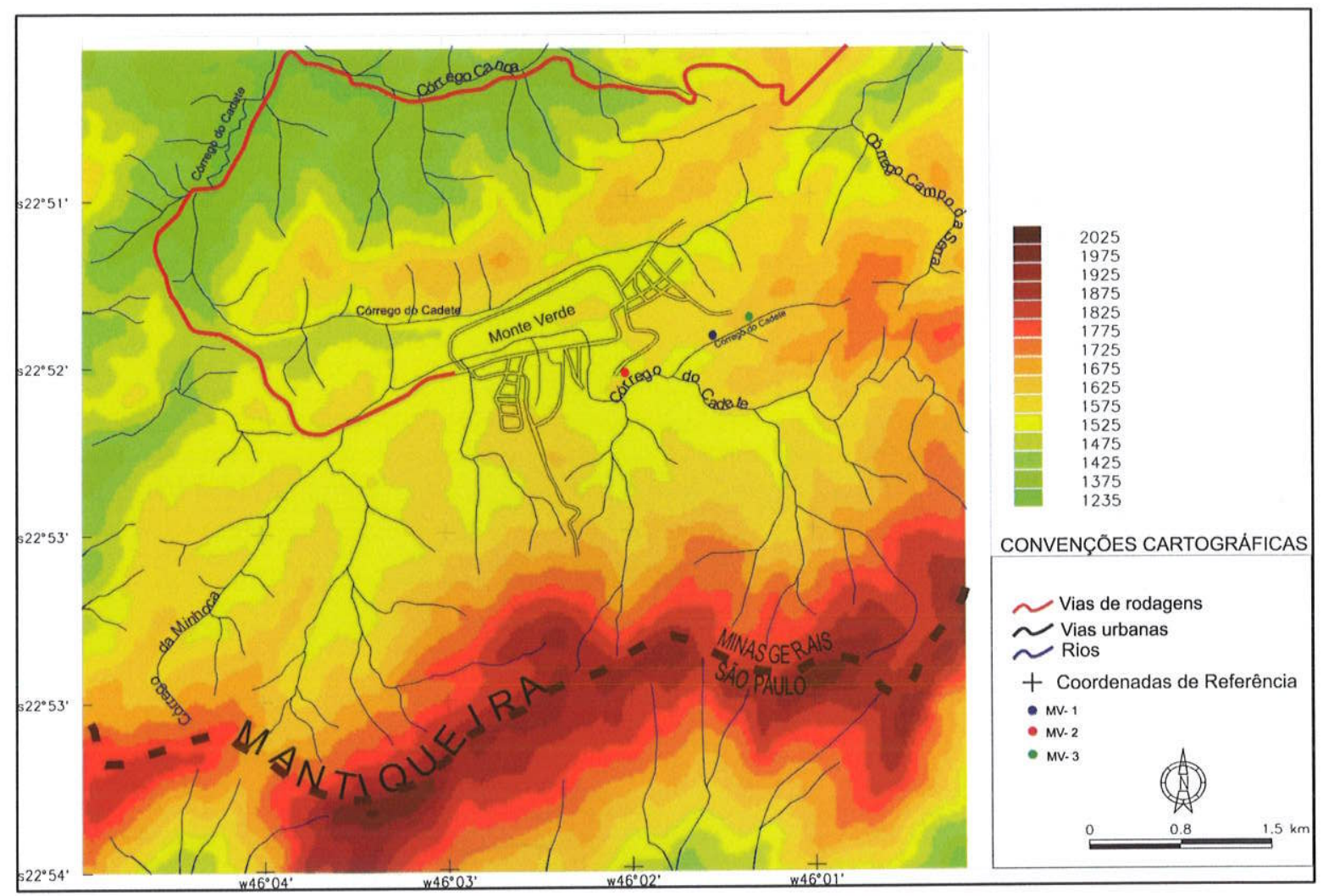

Figura 7- Mapa hipsométrico da região de Monte Verde (baseado em Bistrichi, 2001) com os pontos de coleta de material sedimentar

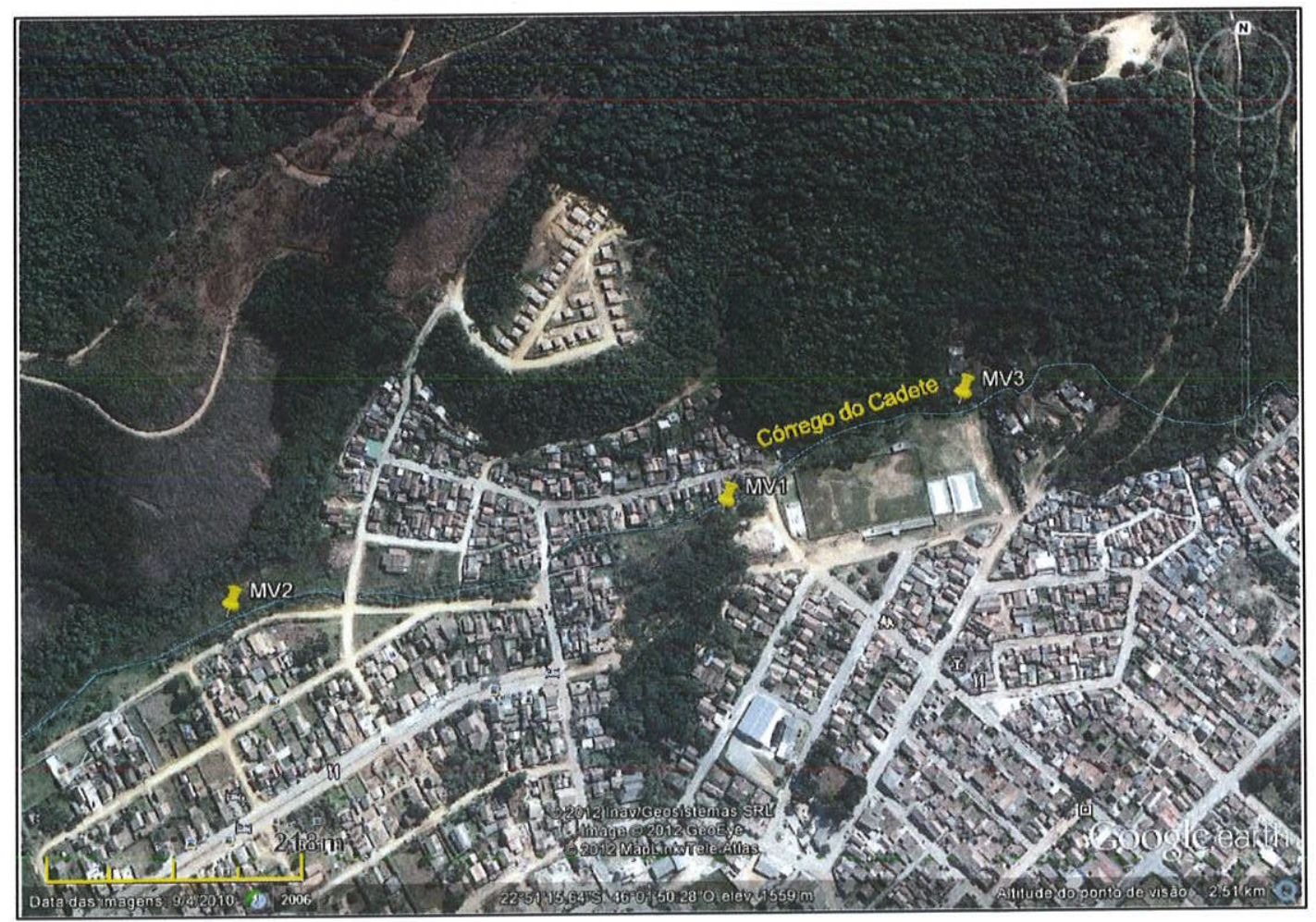

Figura 8- Imagem de satélite da região de Monte Verde com os pontos de coleta de testemunhos, na margem do Córrego do Cadete. Fonte: Google Earth, 2012 
a) Coluna MV1 (profundidade de $232 \mathrm{~cm}$ ): O local amostrado, a aproximadamente $2 \mathrm{~m}$ da margem esquerda do Córrego do Cadete, afluente do rio Jaguari, é urbanizado, com cobertura vegetal escassa, mas com presença de Araucaria, Podocarpus e Sphagnum, entre outros gêneros (Figuras 9 A e B). A coluna amostrada é formada por sedimentos luto-arenáceos, passando da base para o topo de castanho escuro a castanho avermelhado.
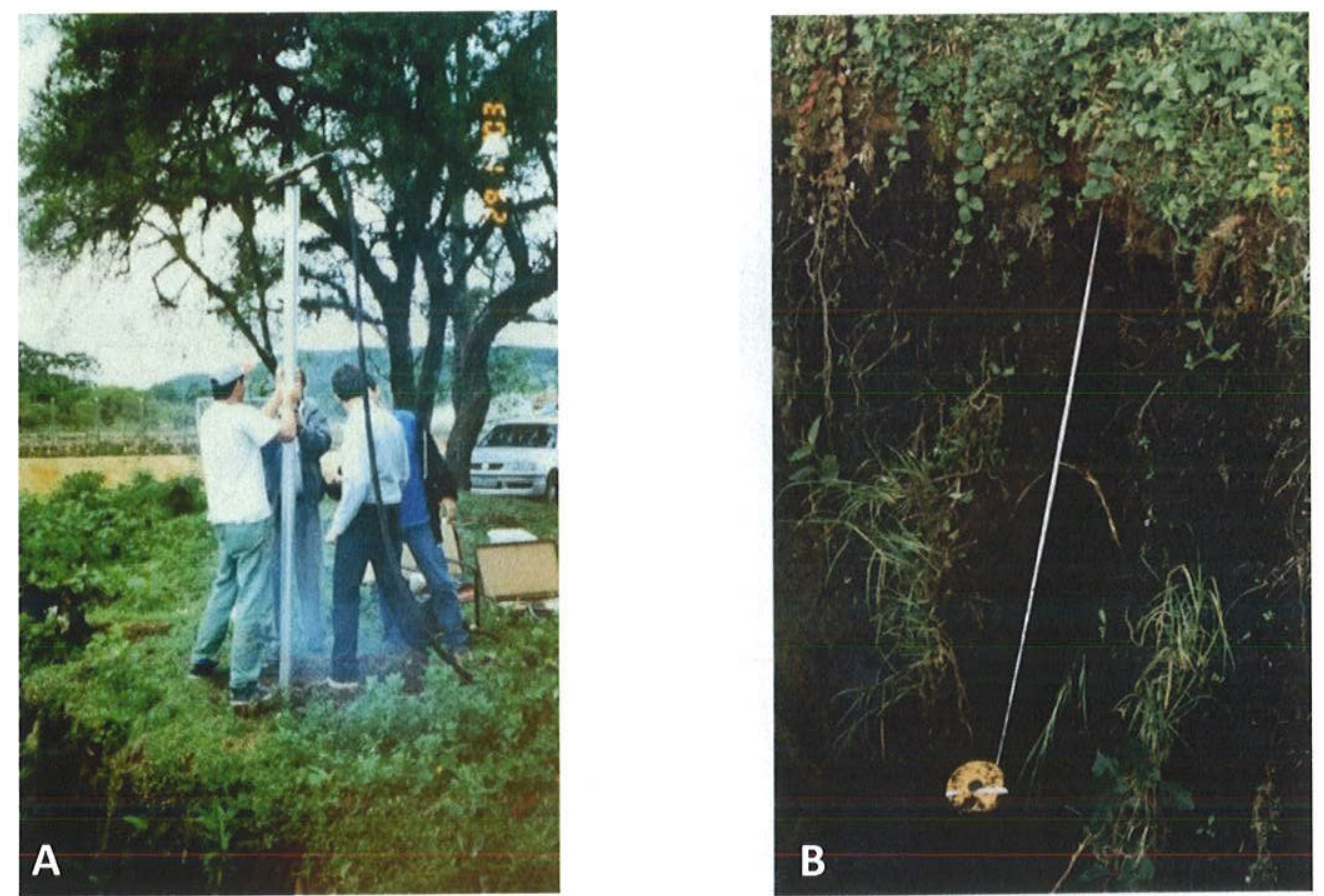

Figuras 9 A e B-Amostragem com vibrocore no ponto MV1 e detalhe do material coletado na margem esquerda do Córrego do Cadete. Esta drenagem corre hoje cerca de $3 \mathrm{~m}$ abaixo do terraço de construção que se vê na foto $9 \mathrm{~A}$.

b) Coluna MV2 (profundidade de $210 \mathrm{~cm}$ ): O primeiro metro superficial desta coluna já foi analisado por Siqueira (2006) (Figuras 9 e 10). O material amostrado nesta coluna, conforme observação em campo, é formado por turfa sáprica (turfa com estruturas vegetais irreconheciveis-Lappalainen, 1979 apud Suguio, 1998), com algumas porções arenosas ao longo da seção. Este ponto de amostragem encontra-se a aproximadamente $900 \mathrm{~m}$ a WSW (jusante) do ponto MV1, em cota topográfica $100 \mathrm{~m}$ inferior, mas com contexto sedimentar análogo, exceto pela presença de uma drenagem contributária vinda de sul, entre os dois pontos (Figuras 6 e 7). O final da penetração, a $210 \mathrm{~cm}$ de profundidade, corresponde à camada de areia grossa, conforme observado pelo exame da base do tubo. 

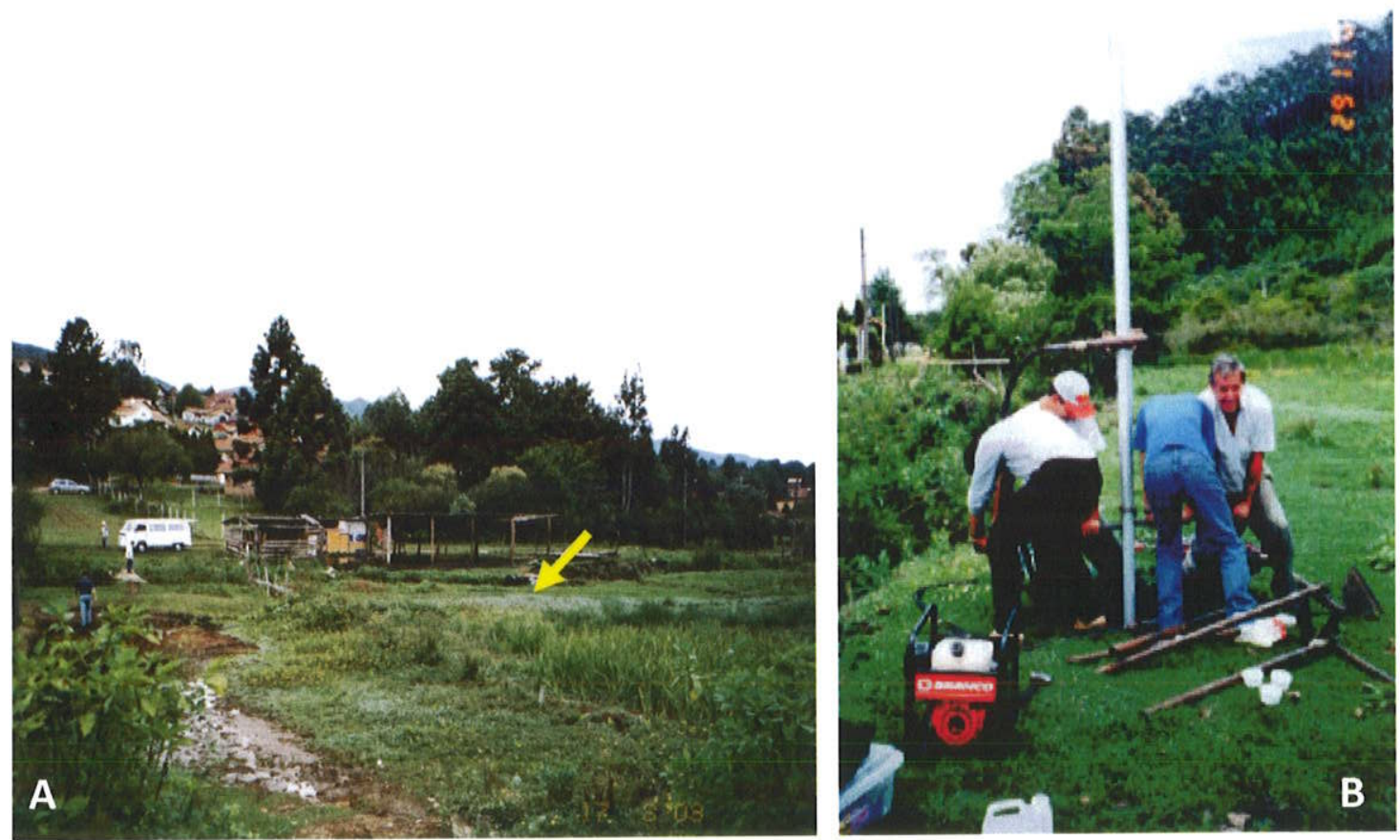

Figura $10 \mathrm{~A}$ e B- Amostragem com vibrocore no ponto MV2, margem esquerda do Córrego do Cadete (indicado pela seta amarela), e contexto de campo do ponto amostrado. Foto 10A obtida de norte para sul

c) Coluna MV3 (profundidade total de $405 \mathrm{~cm}$ ): A amostragem, adjacente a um corte artificial de altura decamétrica, teve a coleta realizada em duas etapas, tendo em vista a construção de seção colunar composta. Na primeira etapa, com a utilização do vibrocore, atingiu-se profundidade de $217 \mathrm{~cm}$ (Figuras 11 A e B). O material atravessado aparentou composição predominantente argilo-turfácea, com presença de lente cascalhosa de espessura decimétrica na base, o que impediu a continuidade da perfuração. Optou-se assim, na segunda etapa, por continuar a amostragem a partir desta lente, através da coleta de amostras pontuais a cada $10 \mathrm{~cm}$, na parede da exposição, o que permitiu chegar até o embasamento granítico alterado, na profundidade de $405 \mathrm{~cm}$. O material coletado nesta amostragem complementar é visualmente composto por argila turfácea com intercalações lenticulares de argila arenosa. 

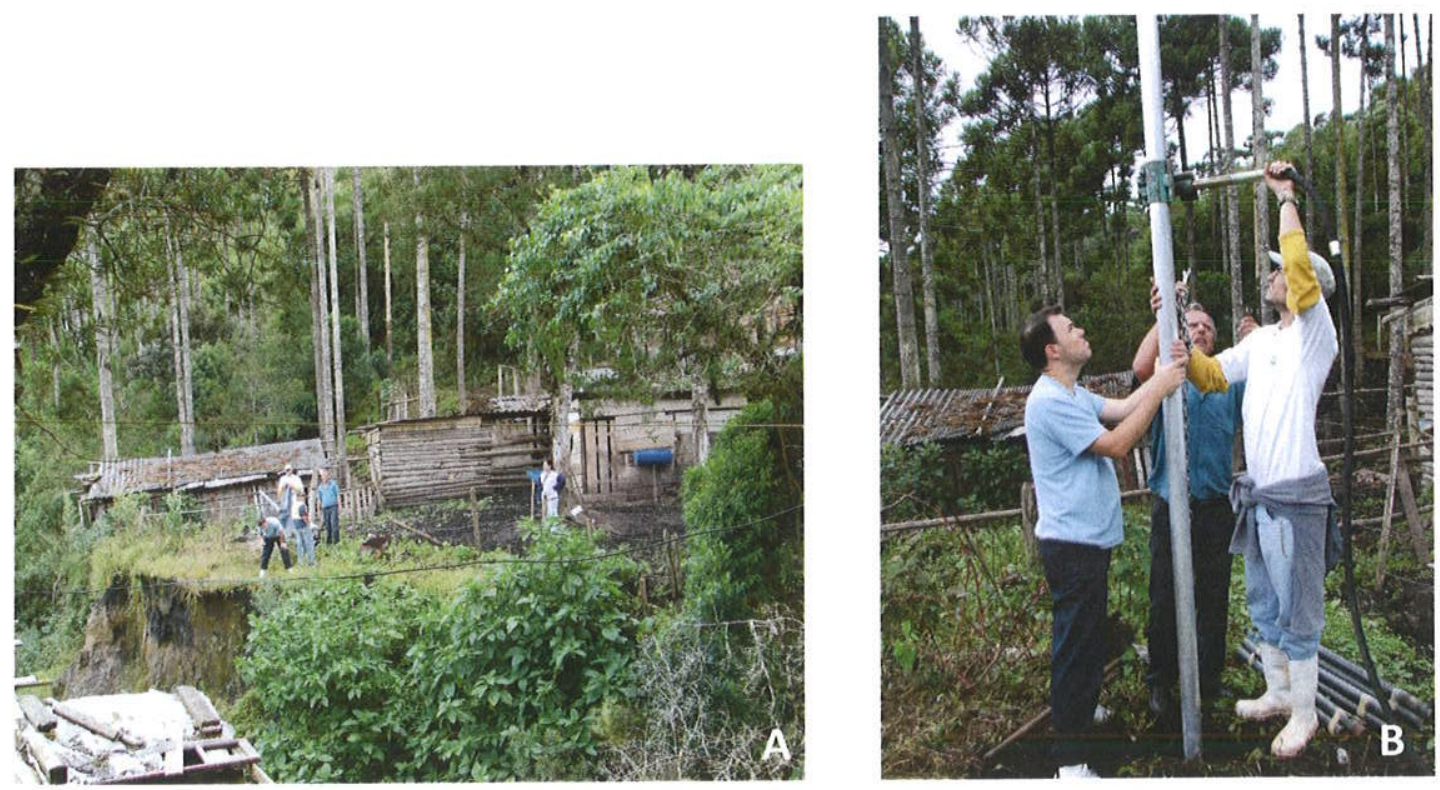

Figuras 11 A e B- Amostragem com vibrocore no ponto MV3, margem esquerda do Córrego do Cadete, e visão geral da área de coleta. O Córrego do Cadete margeia a falésia da imagem 11A, onde é evidente a presença de depósitos cascalhosos, atribuídos a transporte de encosta.

Após a coleta de campo, até o momento da separação de alíquotas para os diferentes tipos de ensaio, as amostras ficaram armazenadas nos respectivos tubos de alumínio, ou sacos plásticos, para evitar contaminação e oxidação do sedimento coletado.

\subsection{Métodos de laboratório}

Os testemunhos foram abertos em laboratório para descrição e separação de alíquotas para ensaios sedimentológicos, químicos, micropaleontológicos e geocronológicos. As principais etapas laboratoriais são descritas a seguir.

\subsubsection{Descrição do testemunho}

Após a abertura dos tubos de alumínio, as colunas de sedimentos obtidas foram medidas com trena, fotografadas e descritas, com ênfase na sucessão estratigráfica baseada em características sedimentológicas visíveis a olho nu, como cor, granulação dominante, estruturas e macrofósseis vegetais. Esta análise teve como finalidade a identificação e caracterização de fácies sedimentares, posteriomente conferida e refinada através dos resultados de ensaios analíticos. 


\subsubsection{Amostragem de alíquotas}

Após a descrição da coluna sedimentar, realizou-se a amostragem das alíquotas para análise palinológica. A cada intervalo de $5 \mathrm{~cm}$, retiraram-se duas alíquotas de $1 \mathrm{~cm}^{3}$, uma para processamento palinológico e outra para datação ${ }^{14} \mathrm{C}$ ou arquivo (Figuras $12 \mathrm{~A}$ e B). As alíquotas foram colocadas em frascos de vidro de igual capacidade volumétrica, lacrados e etiquetados (Figura 13). O restante do material existente no intervalo vertical de $5 \mathrm{~cm}$ foi direcionado para as análises sedimentológicas, cujo objetivo foi investigar possíveis mudanças químicas (teor de matéria orgânica total), granulométricas (teores de areias e finos lutáceos) ou mineralógicas como teor em massa e quantificação de tipos de minerais pesados na fração areia (Figura 13B).
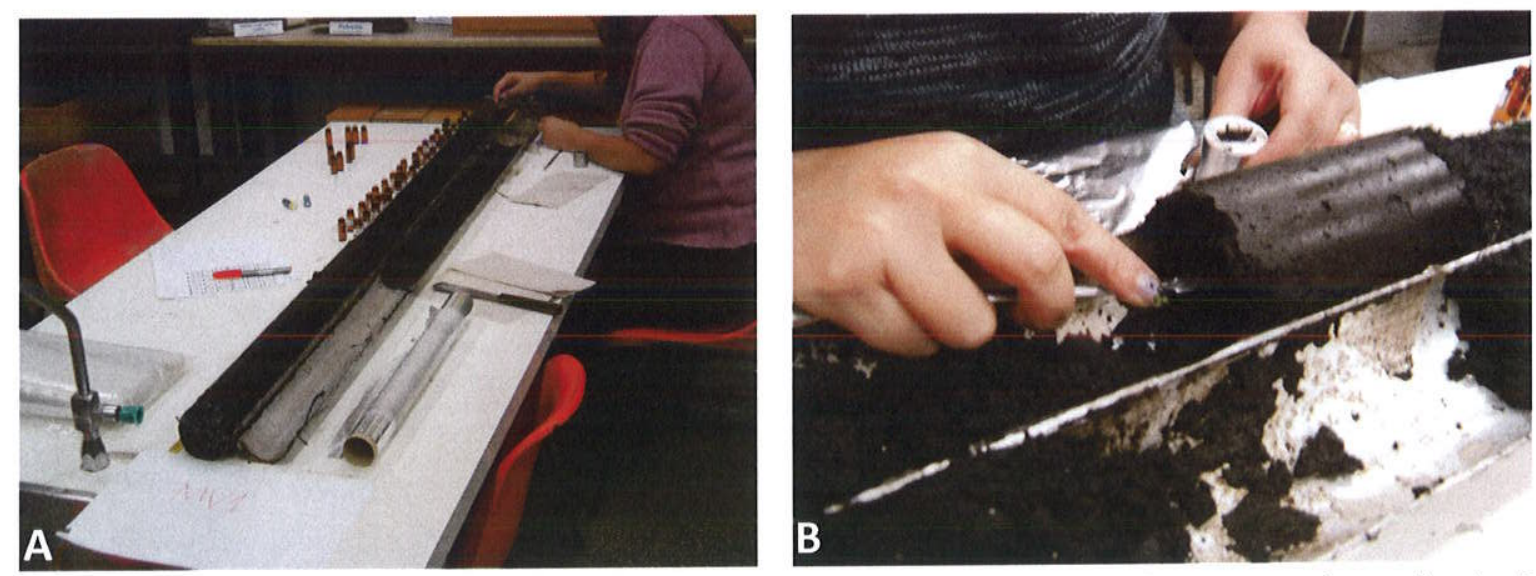

Figuras 12 A e B- Subamostragem de material para palinologia, a partir de testemunho: retirada de duas alíquotas de $1 \mathrm{~cm}^{3}$ a cada $5 \mathrm{~cm}$ de coluna vertical.
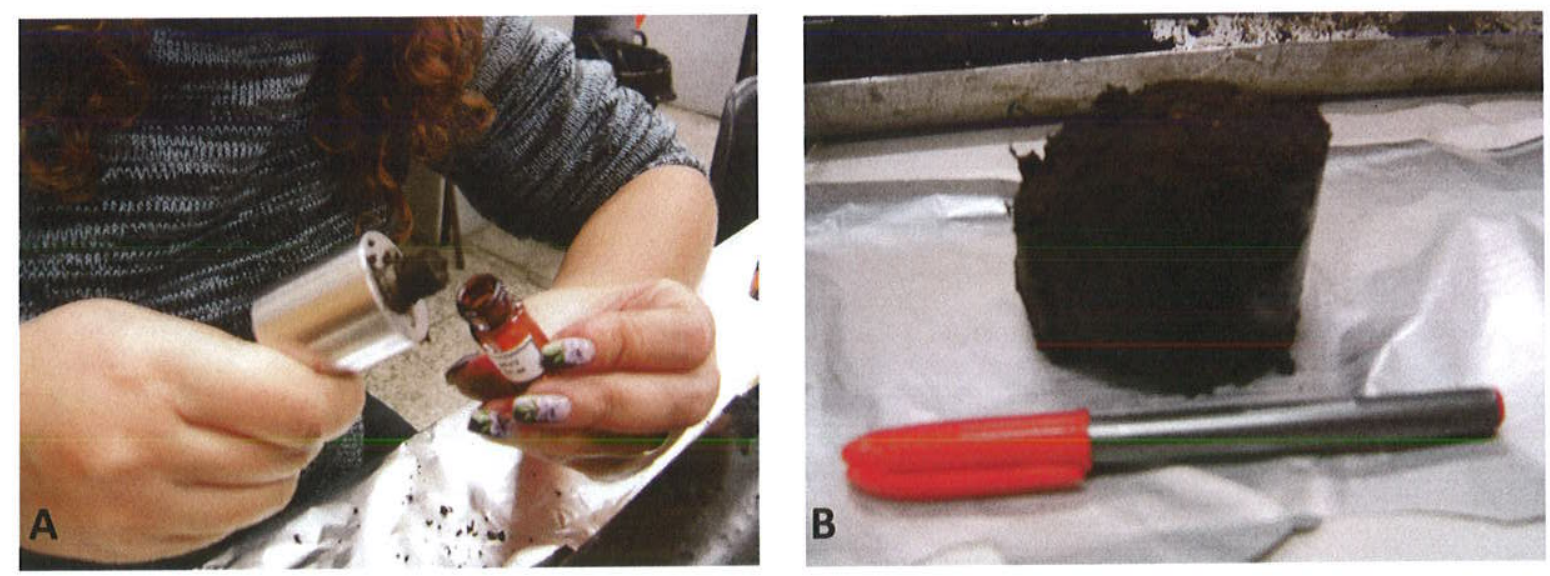

Figuras 13 A e B- Detalhe da subamostragem e do armazenamento das alíquotas para palinologia e datação em frascos de vidro com respectivas identificações. 


\subsubsection{Método palinológico}

As técnicas palinológicas em uso nesta pesquisa encontram-se descritas em detalhes por Colinvaux et al. (1999) e Faegri \& Iversen (1989). Para a remoção de silicatos, o pré-tratamento químico consistiu de banho em HF (ácido fluorídrico) concentrado, por 48 horas, à temperatura ambiente. Ácidos húmicos foram removidos por uma solução $\mathrm{KOH} 10 \%$, seguida de reação de acetólise (cinco partes de anidrido acético para uma parte de ácido sulfúrico). Para a montagem de lâminas permanentes, aos resíduos finais adicionou-se glicerina, sendo as lamínulas vedadas com parafina.

Para a análise quantitativa dos palinomorfos, utilizou-se a técnica da introdução de componente exótico (esporos de Lycopodium clavatum), como em Stockmarr (1971). Esta técnica permite a determinação da concentração absoluta dos palinomorfos, independentemente dos seus valores percentuais na amostra.

Foram contados, fotografados e identificados no mínimo 300 grãos de pólen a cada $10 \mathrm{~cm}$ de intervalo vertical. Após essa etapa, os dados foram refinados a cada $5 \mathrm{~cm}$, para reconstrução mais detalhada da história paleovegetacional e climática da região

Os táxons botânicos encontrados foram identificados e fotomicrografados ao microscópio óptico em aumentos de até 1000x. Em caso de superrepresentação de um ou mais tipos morfológicos, adotou-se utilizar a curva de saturação proposta por Salgado-Labouriau (1973) apud Barberi (1994). Caso contrário, o procedimento adotado consistiu na contagem de no mínimo 300 grãos de pólen arbóreo em cada amostra. A identificação e descrição dos palinomorfos fez-se com uso da palinoteca de referência do professor Paulo Eduardo de Oliveira, da Universidade São Francisco (USF), que contém cerca de 4000 espécies botânicas de diferentes ecossistemas brasileiros, e de bibliografia específica e descritiva, incluindo autores como Erdtman (1969), SalgadoLabouriau (1973), Kuhry (1977), Markgraf (1978), Murillo \& Bless (1978), Tryon \& Tryon (1982), Hammer (1984), Barroso et al. (1991a,b), Roubik \& Moreno (1991), De Oliveira (1992), Garcia (1994), Lorscheitter et al. (1998, 1999, 2000, 2001), Colinvaux et al. (1999), Barroso et al. (2002) e Melhem et al. (2003), entre outros. 


\subsubsection{Método sedimentológico}

O processamento sedimentológico acompanhou o mesmo espaçamento vertical da palinologia, ou seja, por alíquotas a cada $5 \mathrm{~cm}$ de espessura da coluna, de acordo com as etapas descritas a seguir.

\section{Ensaios granulométricos}

As técnicas de análise granulométrica adotadas foram as mecânicas convencionais: pipetagem, elutriação e peneiramento. A realização destes ensaios enquadrou-se no objetivo de caracterizar sedimentologicamente fácies e horizontes estratigráficos. Constituiu também etapa preliminar necessária a análise de minerais leves e pesados. As amostras sedimentológicas foram dispersas mecânica e quimicamente, com adição de pirofosfato de sódio, em provetas de $2000 \mathrm{ml}$, onde se realizou a pipetagem para quantificação dos cinco intervalos de $1 \varnothing$ (escala phi de Krumbein, 1938) entre silte grosso e argila. O material contido na proveta foi, em seguida, submetido a lavagem por elutriação, para eliminação do material lutáceo. Realizou-se a elutriação por fluxo de água ascendente em funil conectado a torneira, conforme procedimentos descritos por Yamamoto (2000) e Melo et al. (2004). Submeteu-se o resíduo arenoso da elutriação a peneiramento ao vibrador mecânico em intervalos de $0,5 \varnothing$, seguindo a escala de Wentworth-Krumbein. Os produtos de peneiramento foram então pesados em balança analítica e embalados para arquivo ou ensaio subseqüente (Figuras $14 \mathrm{~A}$ e B, $15 \mathrm{~A}$ e B).
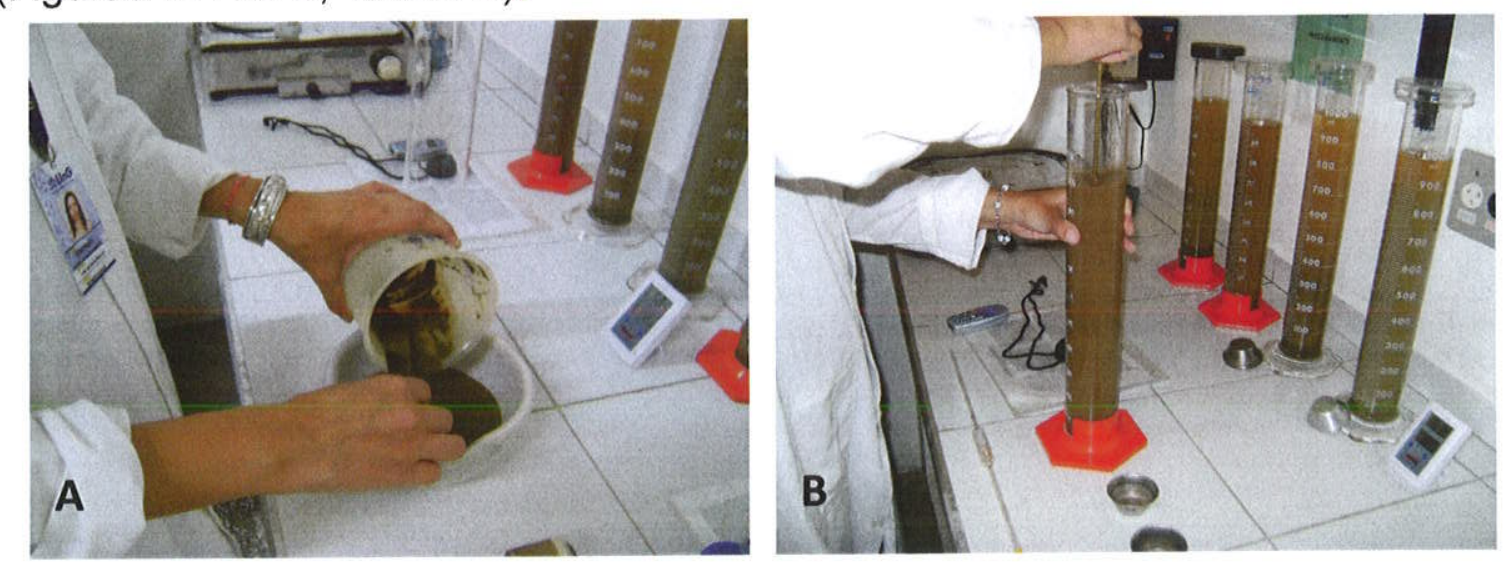

Figura 14 A e B- Ensaios granulométricos: destorroamento do material (A) e preparação da dispersão (com menos de $5 \%$ de sólidos síltico-argilosos) em coluna de pipeta. 

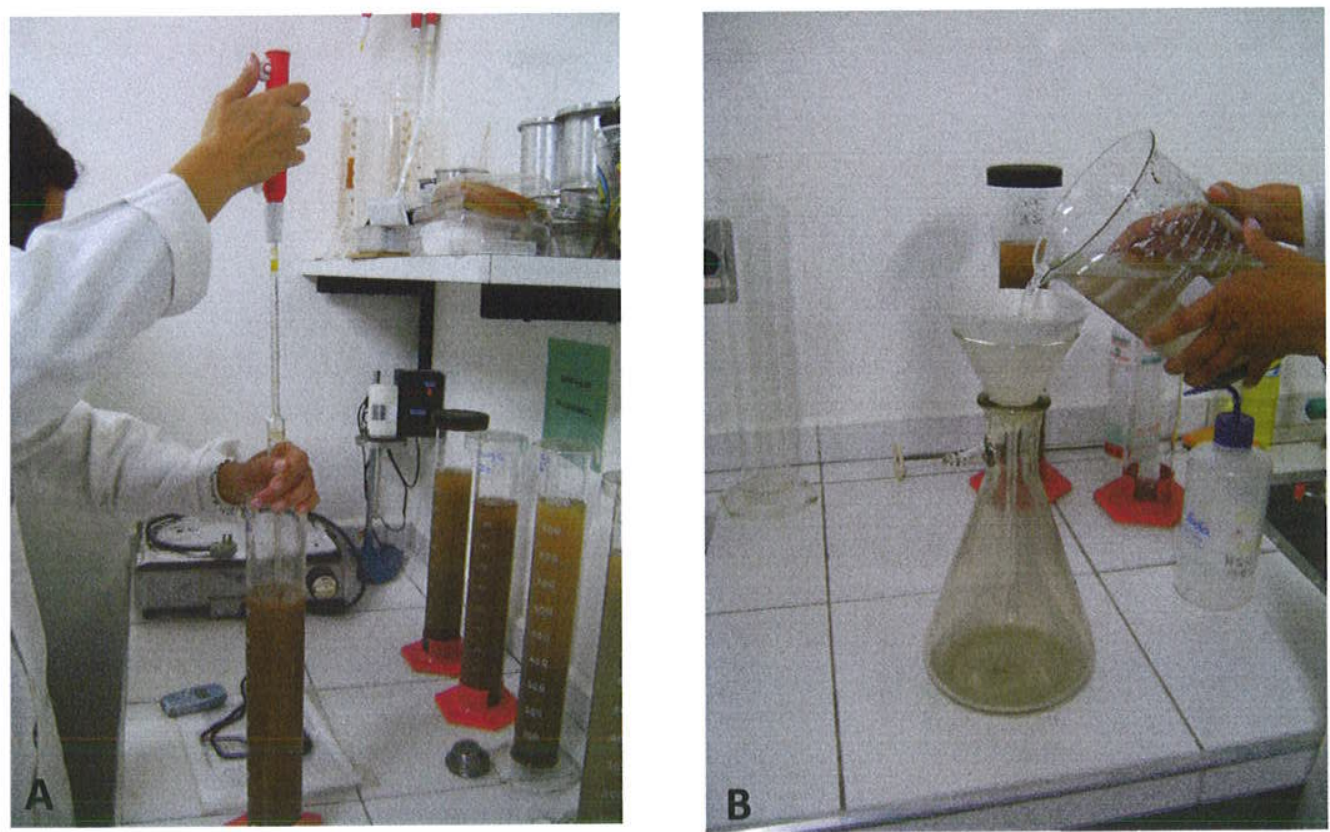

Figuras 15 A e B- Ensaios granulométricos: pipetagem (A) e filtragem da areia após processo de elutriação (B).

\section{Separação de minerais leves e pesados}

Todas as amostras processadas no ensaio de granulometria foram submetidas à análise densimétrica por flutuação-afundamento em líquido denso (bromofórmio $\mathrm{CHBr}_{3}, \mathrm{~d} \sim 2,83$ ), seguindo em linhas gerais procedimentos descritos por Parfenoff et al. (1970), Carver (1971) e Melo et al. (2004). Dos produtos de peneiramento correspondentes aos intervalos entre 2 e $4 \varnothing$, escolheu-se o intervalo de $1 \varnothing$ imediatamente acima (mais fino) da classe modal (Giannini 1993), no caso correspondente a classe areia muito fina (3 a 4 Ø). As frações de minerais leves e pesados assim obtidas foram pesadas em balança analítica de precisão $\left(10^{-4} \mathrm{~g}\right)$.

\section{Separação ao imã manual}

As frações de minerais pesados concentradas ao bromofórmio submeteram-se a separação magnética. Este ensaio consistiu em atritar de maneira suave um imã, devidamente envolvido em saco plástico ou de papel, com espessura maior que $0,5 \mathrm{~mm}$, sobre a fração de grãos pesados previamente espalhada em superfície lisa. 


\section{Confecção de lâminas de grãos pesados}

A confecção de lâminas de grãos de minerais pesados foi realizada em chapa aquecedora a aproximadamente $100^{\circ} \mathrm{C}$, usando-se com Bálsamo do Canadá natural como meio de imersão.

\section{Análises mineralógicas}

As lâminas de grãos de minerais pesados foram examinadas ao microscópio óptico de luz polarizada (petrográfico), para reconhecimento da assembleia mineralógica, quantificada em seguida, dentro de um total de pelo menos 100 grãos (200, onde possível), através da contagem ao longo de uma linha reta (ribbon method de Galehouse, 1971). A contagem foi feita em duas fases. Na primeira, incluíram-se grãos transparentes, opacos e semi-opacos, estes últimos distintos entre agregados argilo-limoníticos e agregados leucoxênicos. Após a totalização de 100 grãos, seguiu-se, na segunda fase de contagem, com a identificação dedicada somente a transparentes, de novo até totalizar pelo menos 100 grãos. Na quantificação de minerais transparentes realizada, considerou-se a presença de alterita, no sentido proposto por Van Andel (1958), isto é, todo mineral com distinção petrográfica segura impossibilitada em vista da perda parcial ou total de propriedades ópticas por efeito de alteração química.

\subsubsection{Métodos geoquímicos e ísotópicos}

As análises geoquímicas e isotópicas de carbono e nitrogênio foram realizadas no Laboratório de Isótopos Estáveis do Centro de Energia Nuclear na Agricultura (CENA), da Universidade de São Paulo (USP), campus Piracicaba. As amostras foram preparadas (Figura $16 \mathrm{~A}$ e $\mathrm{B}$ e Figura $17 \mathrm{~A}$ e B) para determinação do carbono orgânico total $\left(C_{\text {org }}\right)$, nitrogênio total $\left(N_{\text {total }}\right)$ e isótopos estáveis do carbono $\left(\delta^{13} \mathrm{C}\right)$ e nitrogênio $\left(\delta^{15} \mathrm{~N}\right)$ em analisador elementar acoplado a um espectrômetro de massa ANCA SL 2020 da Europa Scientific. Os resultados de $\mathrm{C}$ e $\mathrm{N}$ são apresentados em porcentagem de peso seco, e os de razão 
isotópica em relação ao padrão internacional PDB (Pee Dee Formation Belemnites), para ${ }^{13} \mathrm{C}$, e em relação ao ar, para ${ }^{15} \mathrm{~N}$, em ambos os casos com precisão analítica de $+/-0,2 \%$.

O material foi analisado até a profundidade de $160 \mathrm{~cm}$ e organizados em tabelas por profundidade. Abaixo de $160 \mathrm{~cm}$, as massas não foram suficientes para a realização dos ensaios em função deste intervalo ser mais rico em areia e/ou mais pobre em matéria orgânica coloidal, presente em quantidade insuficiente para as análises.
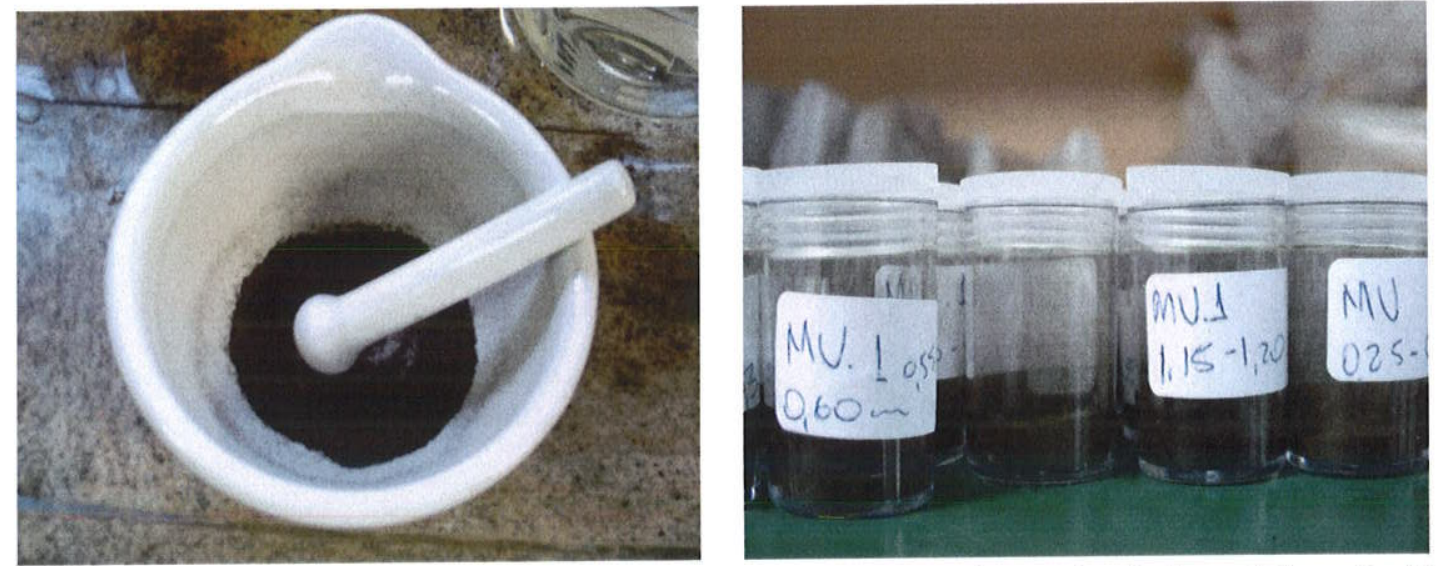

Figuras 16 A e B- Preparação do material para análises geoquímicas e isotópicas: trituração $(A)$ e acondicionamento das amostras (B).
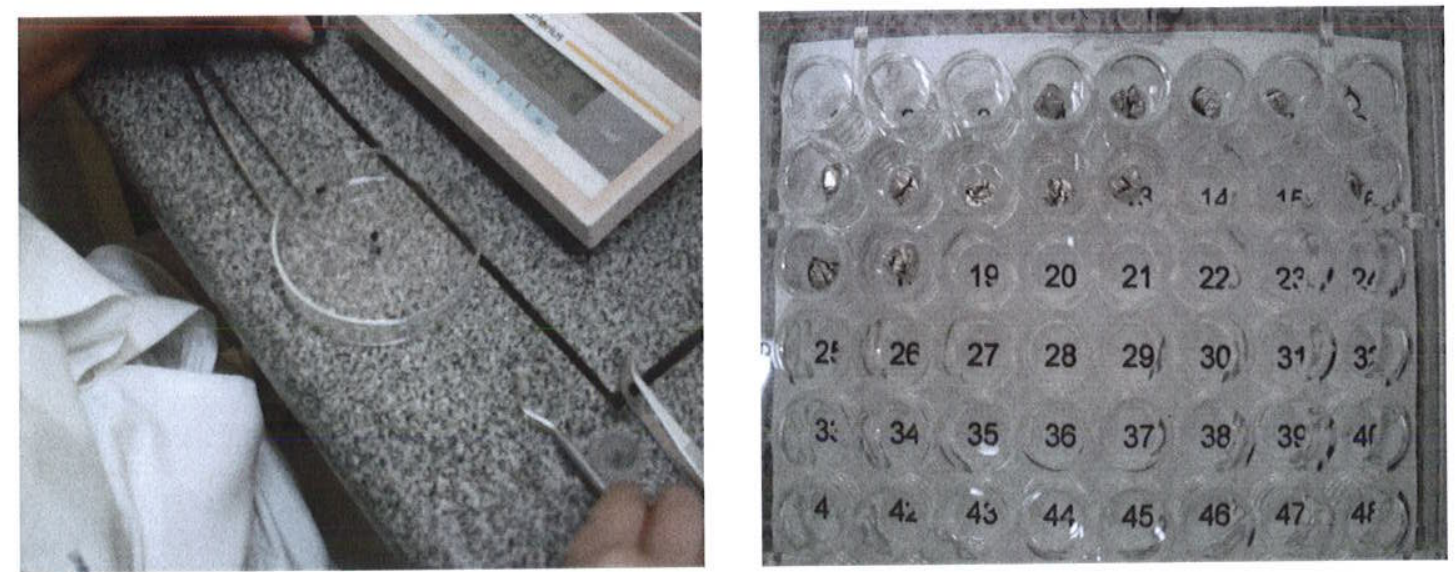

Figura 17 A e B- Preparação para leitura no espectrômetro de massa: pesagem das amostras (A), embaladas em seguida em papel alumínio e acondicionadas em placa numerada (B).

\subsubsection{Datações}

Foram realizadas 16 datações pelo método do ${ }^{14} \mathrm{C}$ AMS (acellerator mass spectrometer), em alíquotas iniciais de $1 \mathrm{~cm}^{3}$ de sedimento orgânico enviadas ao 
laboratório Beta Analytic Inc. (Miami, EUA). Datações apresentadas pelo laboratório sem calibração foram posteriormente calibradas no programa Cal Pal.

\subsubsection{Cálculo de taxas de sedimentação}

De posse de todos os resultados de datação, calcularam-se as taxas de sedimentação média de cada trecho do testemunho compreendido entre dois sucessivos horizontes datados, através dos quocientes entre a espessura de cada trecho e a sua duração máxima e mínima. Estas taxas permitiram inferir, por extrapolação, a idade das profundidades limítrofes de intervalos verticais distintos por critérios palinológicos (biozonas) elou sedimentológicos, e, por extensão, estimar as taxas de sedimentação média também destes intervalos.

\subsection{Tratamento dos resultados}

\section{a) Construção das seções colunares}

A divisão do testemunho em fácies foi representada graficamente por meio de seções colunares. Em vista das características específicas dos sedimentos estudados, como o teor constantemente elevado de silte mais argila (sempre maior que $40 \%$ ), a escala do eixo horizontal das seções colunares, relativa à granulação, teve adaptações em relação à forma de representação mais usual em estratigrafia. Esse eixo foi dividido em lama arenosa muito fina (LAMF), lama arenosa fina (LAF), lama arenosa média (LAM), lama arenosa grossa (LAG) e areia lamosa $(\mathrm{AL})$. A classificação preliminar visual e tátll foi conferida com os resultados de análise granulométrica. Usou-se o termo principal lama, para os depósitos com mais de $50 \%$ de silte mais argila, e areia, para os depósitos com menos. O segundo termo, adjetivo (desde arenosa grossa até lamosa), foi usado sempre que a classe ou fração em questão ultrapassasse $5 \%$ em massa. Assim, por exemplo, a fácies lama arenosa média a muito fina corresponde a depósito com mais de $50 \%$ de silte mais argila, no qual o teor de cada uma das classes areia média, areia fina e areia muito fina atinge concentração igual ou superior a $5 \%$. 


\section{b) Palinologia}

Com os resultados de contagem polínica, confeccionaram-se diagramas de porcentagem e concentração, através dos programas Tilia / Tilia Graph (Grimm, 1987), que permitem a avaliação gráfica das alterações vegetacionais ao longo das seções colunares, para finalidades de interpretação paleoambiental.

A utilização do programa Tilia torna possível gerar valores de porcentagem e concentração (grãos por $\mathrm{cm}^{3}$ ) obtidos para cada táxon, somados de modo a perfazer totais parciais de pólen arbóreo, arbustivo e herbáceo. Para o cálculo de concentração de palinomorfos, utilizaram-se variáveis referentes à concentração do esporo exótico por pílula e a quantidade desses esporos na contagem polínica (Stockmarr, 1971).

A técnica de adição de esporo exótico tem a vantagem de eliminar possiveis distorções na interpretação dos dados polínicos causados pela análise percentual, ou seja, dados percentuais podem levar a uma supervalorização de táxons que são prolíficos produtores de pólen, como as ervas com polinização anemófila e outros táxons invasores, ao contrário de táxons de vegetação clímax cuja produção polínica não é tão volumosa. Com a técnica do Lycopodium exótico, os valores de concentração de cada táxon são independentes entre si, ao contrário dos cálculos percentuais, e permitem uma melhor estimativa da abundância dos táxons na paisagem (Salgado-Labouriau, 2007)

\section{c) Sedimentologia}

A partir dos resultados brutos de distribuição granulométrica obtidos através das técnicas de pipetagem e peneiramento, foram calculados os valores das estatísticas de tendência central (diâmetro médio, desvio padrão) e caudal (assimetria e curtose), pelo método analítico dos momentos de Pearson, através do programa Momento 4.xls, de Giannini \& Nascimento (2005), versão plus (elaborada por Vitor Paulino de Aguiar e Rodolfo Marinho, do Laboratório de Sedimentologia do Instituto de Geociências da USP).

$\mathrm{Na}$ análise da variação vertical das medidas estatísticas da distribuição granulométrica, ao longo das seções colunares, procurou-se aplicar os princípios 
da chamada "regra de McLaren". De acordo com esse autor (McLaren, 1981), o tamanho do grão (diâmetro médio), a seleção (desvio padrão) e a assimetria de um depósito sedimentar são controlados por características da área fonte e pelos processos de erosão e seleção durante o transporte. Desse modo, existiriam padrões de variação da distribuição granulométrica entre a fonte e o sítio deposicional. Dentro deste princípio, McLaren \& Bowles (1985) admitem a existência de dois padrões de variação combinada de estatísticas descritivas da distribuição granulométrica que indicariam inequivocamente o rumo de transporte ou de retrabalhamento sedimentar: "mais fino, mais selecionado, mais negativo" e "mais grosso, mais selecionado, mais positivo". Assim, a verificação de um destes dois tipos de variação em dado rumo espacial seria indicativa de transporte sedimentar nesse rumo.

O uso do método de McLaren \& Bowles (1985) combinado com a análise de variação espacial de minerais pesados de diferentes estabilidades e equivalentes hidráulicos têm possibilitado a inferência do rumo de transporte predominante e de crescimento progradacional para areias quaternárias (Giannini et al. 2003, 2004, Tanaka 2007, Tanaka et al. 2008, 2009a, 2009b, Guedes 2009). O método tem sido usado também, de modo adaptado, para inferir retrabalhamento sucessivo em sucessões de depósitos cada vez mais novos (Tanaka et al. 2008, 2009a, 2009b). É neste segundo modo que o método de McLaren foi aplicado nesta Tese.

Calculou-se o índice ZTR, somatório de minerais ultraestáveis (zircão, turmalina e rutilo) dentre grãos pesados transparentes não micáceos, de acordo com a definição original de Hubert (1962). De modo análogo, foram calculados índices somatórios de minerais metaestáveis (estaurolita, apatita, epídoto, cianita, sillimanita, granada) e instáveis (piroxênios, anfibólios e andaluzita), adotando-se a classificação de estabilidade de minerais pesados de Pettijohn (1957).

Os fatores geológicos que controlam a assembleia de minerais pesados e que podem, portanto, a partir dela, serem interpretados, resumem-se em passivos, referentes ao fornecimento da matéria-prima sedimentar pelas áreas fontes, e capazes de determinar a disponibilidade e tamanho inicial dos minerais, e ativos, relativos a quatro tipos principais de processos atuantes sobre esta 
matéria-prima: intemperismo, abrasão mecânica, seleção hidráulica e dissolução pós-deposicional (Morton \& Hallsworth, 1994; Guedes et al., 2009).

As assembleias de minerais pesados possuem portanto origem complexa, multi-controlada, mas os vários fatores controladores podem ser agrupados em tês principais: área ou rocha fonte, seleção durante o transporte ("hidráulica") e dissolução pós-deposicional. Como forma de melhor avaliar a influência de cada um destes três fatores controladores maiores, utilizou-se o método dos índices $\mathrm{ABi}$, inspirado na proposta de Morton \& Hallsworth (1994), e que consiste em comparar entre si pares de minerais ( $A$ e $B$ ) cujas propriedades físico-químicas tornem-nos similares em dois dos fatores controladores, mas contrastantes em relação ao terceiro. Os índices foram calculados pela equação 1, proposta por aqueles autores.

$$
A B i=100 \times(A /(A+B)) \quad \text { (Equação 1) }
$$

A ideia do estudo de índices $\mathrm{ABi}$ é fazer com que apenas um fator controle, em tese, a variação de cada par de minerais escolhido para avaliação. Com isso, torna-se possivel inferir a efetividade de cada fator, no estudo de caso, com base na variação espacial dos pares mineralógicos no respectivo registro sedimentar, seja em mapa seja em sucessão vertical.

$\mathrm{Na}$ escolha dos pares de minerais para cálculo dos índices $\mathrm{ABi}$, deve-se dar preferência, por razões de representatividade estatística, a componentes com alta freqüência e abundância nas amostras estudadas. No entanto, o uso dos índices $\mathrm{ABi}$ foi dificultado pelo fato de a assembleia de minerais pesados transparentes ser francamente dominada por dois componentes, zircão e epídoto. Por exemplo, para determinação de variação de áreas fontes, planejou-se de início utilizar, o par rutilo-zircão, ambos com comportamento físico e químico análogos, porém o rutilo demonstrou ocorrência errática nas amostras estudadas. Como pares de minerais com propriedades físicas (densidade e hábito) parecidas, mas com estabilidade química contrastante, indicados para se analisar a maturidade química e idade relativa do sedimento, utilizaram-se turmalinahornblenda $(\mathrm{TH})$ e sillimanita-hornblenda $(\mathrm{SH})$. Já para o estudo de transporte sedimentar, adotou-se o par turmalina-zircão (TZ), minerais semelhantes do ponto 
de vista da estabilidade química, mas com hábito, densidade e equivalente hidráulico distintos. Adicionalmente, testou-se o uso do índice composto pelos dois minerais mais abundantes na assembleia: zircão/epídoto (ZE). Este índice está potencialmente também relacionado ao controle hidráulico, haja vista o contraste de densidade entre os dois minerais (4,4 versus 3,5 , respectivamente). Não se descarta, porém, a influência de outros fatores sobre o índice ZE, como área fonte e dissolução (epídoto mais sensível que zircão).

As assembleias de minerais pesados e os índices de maturidade mineralógica e ABi calcularam-se através do programa Pondcont 2000.123, de Giannini (1999).

Os resultados granulométricos e mineralógicos obtidos foram lançados em gráficos de barras em função da profundidade do furo, utilizados para a verificação do comportamento dos atributos sedimentológicos ao longo do testemunho e sua comparação com os gráficos palinológicos do programa Tilia Graph, construídos de modo similar. Para efeito de análise e discussão de resultados, os atributos sedimentológicos são abordados nesta Tese na seguinte ordem: proporções de distribuição granulométrica; parâmetros estatísticos de distribuição granulométrica e quantificação de minerais pesados.

\section{d) Geoquímica e isotópos}

Os resultados geoquímicos $e$ isotópicos foram lançados em gráficos de barras para verificação do seu comportamento em relação à profundidade do testemunho e respectiva idade. Essas variações foram comparadas com os espectros polínicos para reconstrução da paleovegetação na área de estudo. Para testar a hipótese de que o $\mathrm{C}$ e $\circ \mathrm{N}$ estão de fato ambos relacionados à matéria orgânica sedimentar e que podem portanto terem seus isótopos interpretados em termos de fonte desta matéria orgânica, os teores totais destes elementos foram lançados em gráficos de dispersão binária, por testemunho, com cálculo do coeficiente de correlação linear e do intervalo de confiança (alfa ou erro I) da correlação, isto é, da probabilidade de aceitar-se correlação inexistente. Normalmente, exigem-se neste teste valores de erro I iguais ou inferiores a 0,1. 


\subsection{Interpretação dos resultados integrados}

Para a interpretação final dos dados integrados, estabeleceram-se os seguintes passos: 1 . determinar as características sedimentológicas, palinológicas e isotópicas que melhor se correlacionam entre si e com a idade deposicional; 2. inferir o modo pelo qual estas caracteristicas podem ser respostas a mudanças em variáveis imediatas como de paleovegetação e dinâmica sedimentar; 3 . inferir as formas de mútua interação entre estas variáveis imediatas; 4 . inferir os mecanismos pelos quais estas mesmas variáveis respondem a fatores mediatos, com destaque para clima; 5 . esboçar os mecanismos gerais de controle exercido pelas fatores mediatos sobre o conteúdo micropaleontológico e sedimentológico dos depósitos nos diferentes testemunhos. 


\section{RESULTADOS}

\subsection{Análise de fácies}

Na seção colunar MV1, com profundidade total de $232 \mathrm{~cm}$, a fácies basal é lamosa, castanho escura, com areia muito fina a média e presença de raízes in situ. Na profundidade de $110 \mathrm{~cm}$, ocorre a transição para fácies de lama com areia muito fina até grossa, cor castanho avermelhado, em que aumentam gradualmente para cima a proporção e a granulação da areia (Figura 18). Esta sucessão pode ser preliminarmente interpretada como resultante da passagem de fácies de planície de inundação fluvial brejosa, distal, para fácies de planície cada vez mais proximal ao canal fluvial. Como a sucessão foi encontrada em terraço de construção, escavado pelo curso atual do córrego do Cadete, pode-se supor também que, desde a idade deposicional do topo do terraço (2060 - 1880 anos cal AP), houve abaixamento do nivel de base de erosão local.

A sucessão sedimentar de $230 \mathrm{~cm}$ encontrada no testemunho MV2 apresentou pouca variação de cor, predominando o preto e o preto acastanhado. Contrastes de granulação e na presença de raízes e restos vegetais permitiram reconhecer seis fácies deposicionais (Figura 19), em seguida numeradas de baixo para cima. A fácies 1 , abaixo de $160 \mathrm{~cm}$ de profundidade, caracteriza-se por lama arenosa média a muito fina, com elevada concentração (maior que $50 \%$ em volume) de raizes in situ. Apresenta evidente granodecrescência ascendente, através da qual passa em contato transicional, na profundidade aproximada de $160 \mathrm{~cm}$, para a fácies 2 , lama arenosa fina a muito fina rica em matéria orgânica coloidal. O contato da fácies 3 sobre a fácies 2, na profundidade $125 \mathrm{~cm}$, é marcado por engrossamento acentuado de granulação, que passa a areia fina a muito fina lamosa, também rica em matéria orgânica coloidal. A fácies 3 é delgada, com espessura centimétrica, e passa em granodecrescência ascendente, na profundidade $120 \mathrm{~cm}$, para a 4, lama arenosa fina a muito fina. A fácies 5 , entre 110 e $45 \mathrm{~cm}$ de profundidade, também corresponde a lama arenosa fina a muito fina, porém agora rica em matéria orgânica tanto coloidal quanto particulada (turfa sáprica). A fácies 6 , nos $45 \mathrm{~cm}$ superiores da coluna, é semelhante à anterior, dela diferindo basicamente pela menor presença de areia e 
detritos vegetais e pela cor ligeiramente mais clara, preto acastanhado. A sucessão sedimentar encontrada em MV2, se interpretada nos mesmos moldes que a de MV1, indicaria associação de fácies de planície de inundação, só que agora com redução da influência sedimentar do canal fluvial ao longo do tempo, até chegar-se, no topo, a um contexto deposicional similar ao atual, que é o de planicie de inundação com aporte eventual de sedimentos de encosta. De modo similar a MV1, a idade do topo da sequência aponta para predomínio de erosão nos últimos 2000 anos A.P.

$\mathrm{Na}$ coluna MV3, cinco fácies foram reconhecidas, sendo uma dominantemente arenosa e quatro argilosas (Figura 20). A sucessão de fácies encontrada, de $405 \mathrm{~m}$ de espessura, repousa diretamente sobre a rocha granitóide alterada. Inicia-se por argila preta rica em fragmentos vegetais (turfácea), fácies que recorre no topo da sucessão. As outras fácies, na ordem de aparição da base para o topo são: argila preta siltosa maciça, em padrão granodecrescente; areia cinza muito fina maciça, com geometria lenticular; argila preta turfácea maciça, com grânulos dispersos; e argila preta maciça compacta, com grânulos e presença de raízes crescente para o topo. A sucessão reflete a intercalação de processos de três tipos principais, todos típicos de encosta: fluxos de massa coesivos (mud flows), materializados nas fácies com grânulos; enxurradas em lençol, representadas pelas lentes de areia; e deposição de finos por suspensão e solifluxão lenta (creeping), correspondente às fácies argilosas maciças. Os fluxos de massa representariam a fácies mais proximal e as enxurradas, a mais distal, relacionadas a episódios de instabilização de encosta. Períodos de estabilização de encosta e redução da taxa de deposição clástica seriam marcados pelos niveis turfáceos e com desenvolvimento de raízes.

A coluna MV3 não foi analisada sob o ponto de vista paleoambiental por apresentar baixa concentração de palinomorfos e inversão de idade na profundidade de $120 \mathrm{~cm}$, além de má qualidade de preservação do escasso material polínico existente. Essas características comprometem a análise integrada de variáveis a que este trabalho se propôs. 


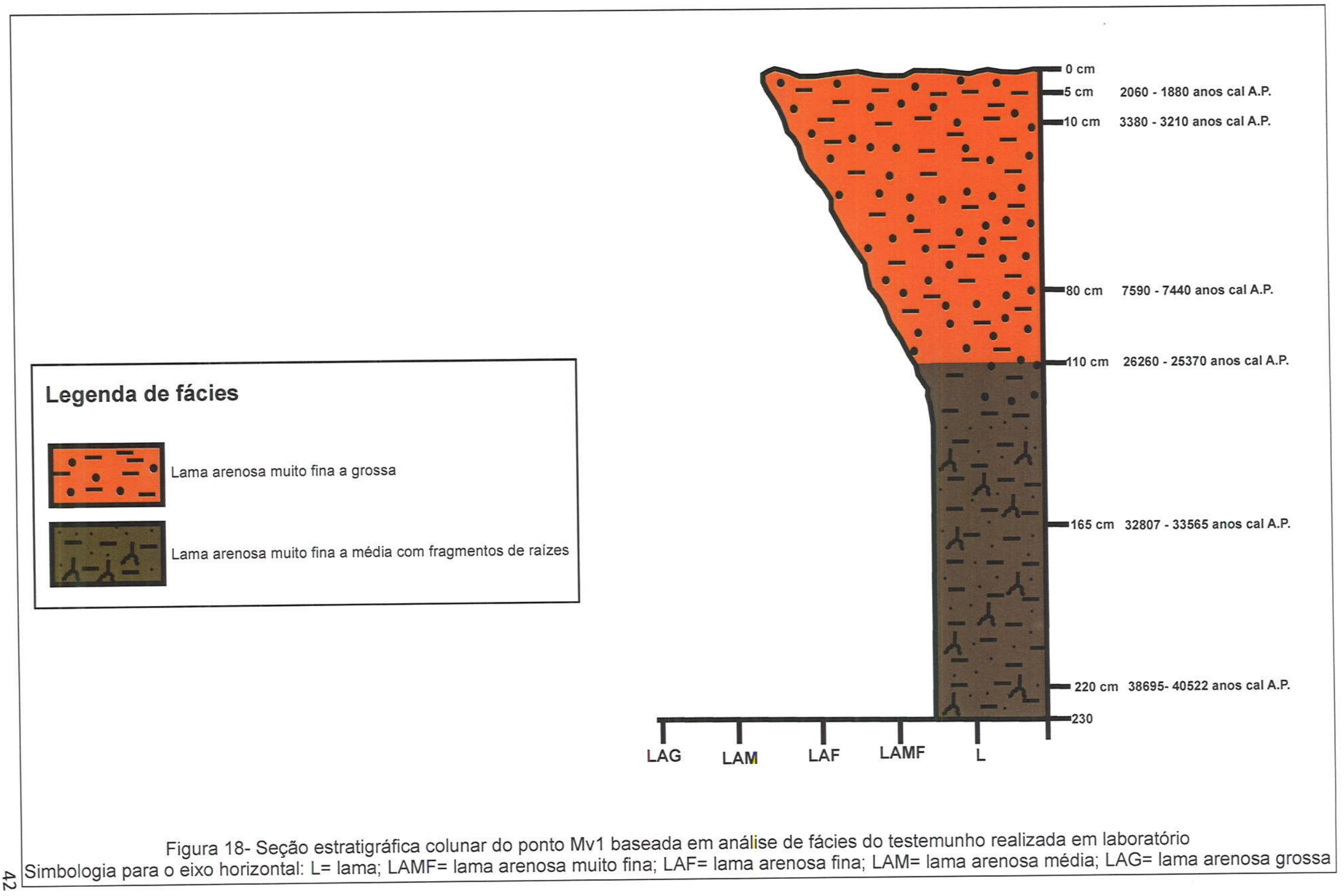




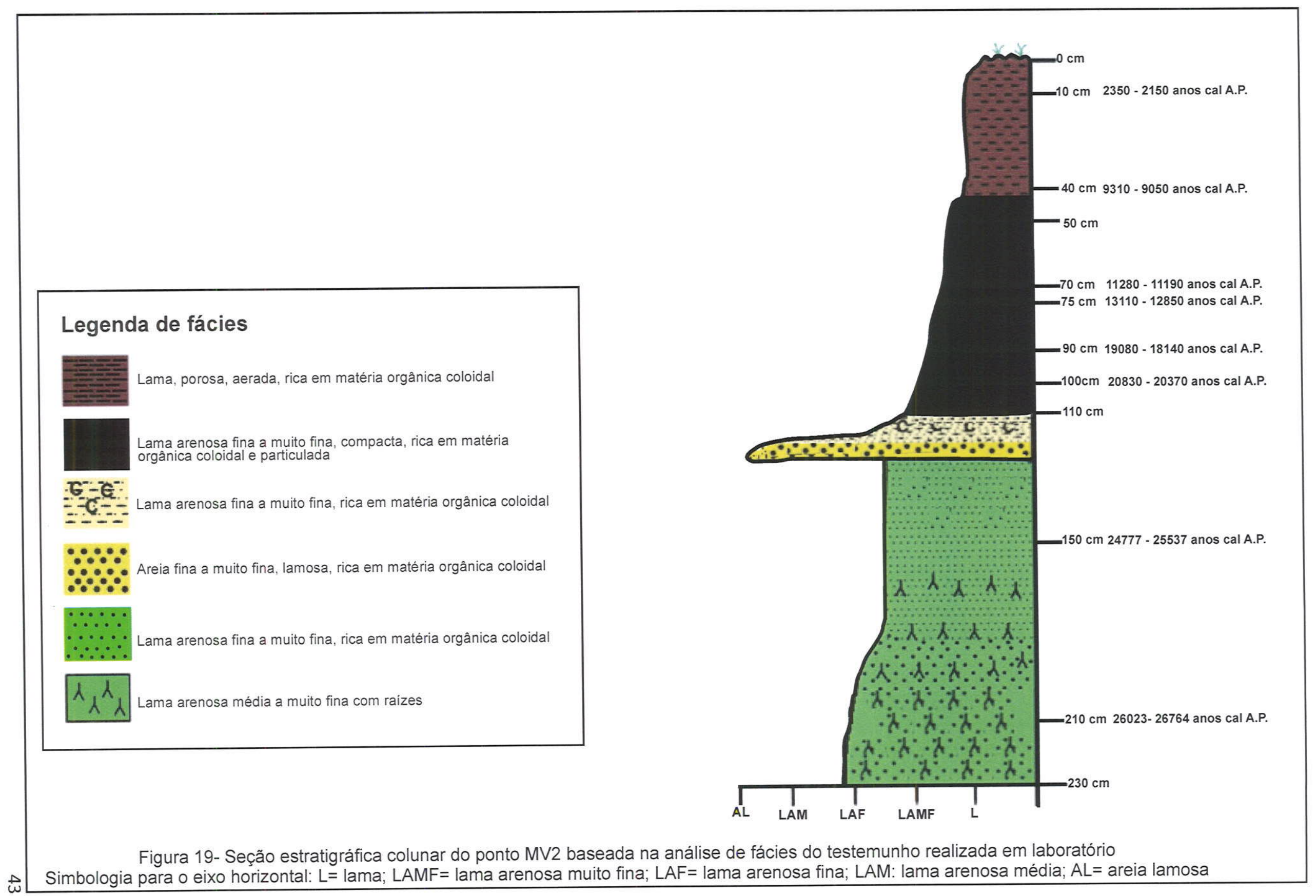




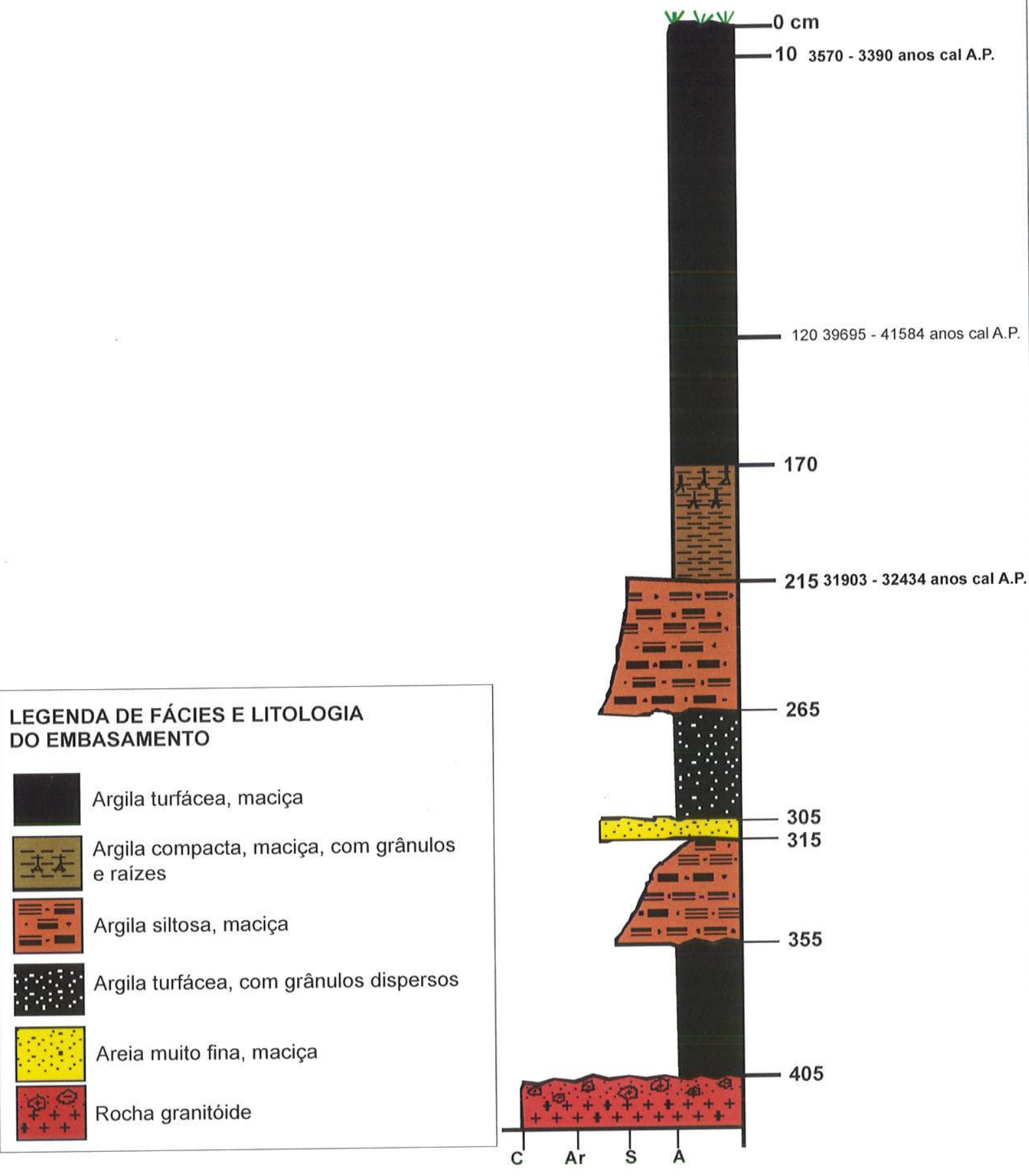

Figura 20- Seção estratigráfica colunar composta do ponto MV3 baseada em análise de fácies do testemunho realizada em laboratório 


\subsection{Datações}

Os resultados da datação ${ }^{14} \mathrm{C}$ AMS obtidos encontram-se listados na Tabela 2. No testemunho MV1, realizaram-se seis datações, com idade mínima de 2060-1880 anos cal A.P., a $5 \mathrm{~cm}$ de profundidade, e máxima de 38695-40522 anos cal A.P., a $220 \mathrm{~cm}$ de profundidade. No testemunho MV2, dispõe-se de oito datações, com idade mínima de 2350-2150 anos cal A.P., a $10 \mathrm{~cm}$ de profundidade, e máxima de 26023-26764 anos cal A.P., a $210 \mathrm{~cm}$ de profundidade. O testemunho MV3, com três datações, possui idade compreendida entre 3570 - 3390 anos cal A.P., à profundidade de $10 \mathrm{~cm}$, e $31903-32434$ anos cal A.P., à profundidade de $215 \mathrm{~cm}$.

O padrão de variação de idade máxima logicamente esperado, de montante para jusante ao longo da planície do córrego do Cadete (de MV3 para MV1 e deste para MV2), seria de decréscimo gradual. Quanto mais a jusante se encontra a planície fluvial, maiores tendem a ser em tese a relação deposição/erosão e a taxa de sedimentação média e, portanto, mais nova a idade da coluna sedimentar de dada espessura (a qual é similar nos três testemunhos estudados). Este padrão foi de fato observado na relação entre MV2 e MV1, o primeiro mais a jusante e mais novo que o segundo. Já MV3, apesar de mais a montante, resultou mais novo que MV1 (descartada a idade em $120 \mathrm{~cm}$, considerada de material retrabalhado). Este resultado aparentemente anômalo explica-se pela marcante diferença de fácies entre as colunas sedimentares MV3 e MV1, isto é, o forte registro em MV3 de processos de fluxos de massa de encosta, para os quais se espera efeito de elevação da taxa de sedimentação. Não se deve descartar a possibilidade de a idade da base de MV3 ser ainda mais nova que a indicada, dada a chance de retrabalhamento de material orgânico preexistente por efeito de fluxos gravitacionais. 
Tabela 2- Resultados calibrados de datação ${ }^{14} \mathrm{C}$ AMS.

\begin{tabular}{|c|c|c|}
\hline $\begin{array}{l}\text { PROFUNDIDADE } \\
(\mathrm{cm})\end{array}$ & $\begin{array}{c}\text { DATAÇÃO } \\
\text { (anos cal A.P.) }\end{array}$ & $\begin{array}{l}\text { MATERIAL } \\
\text { DATADO }\end{array}$ \\
\hline \multicolumn{3}{|c|}{ MV1 } \\
\hline 5 & $2060-1880$ & \multirow{6}{*}{$\begin{array}{l}\text { Sedimento } \\
\text { orgânico }\end{array}$} \\
\hline 10 & $3380-3210$ & \\
\hline 80 & $7590-7440$ & \\
\hline 110 & $26260-25370$ & \\
\hline 165 & $32807-33565$ & \\
\hline 220 & $38695-40522$ & \\
\hline \multicolumn{3}{|c|}{ MV2 } \\
\hline 10 & $2350-2150$ & \multirow{8}{*}{$\begin{array}{l}\text { Sedimento } \\
\text { orgânico }\end{array}$} \\
\hline 40 & $9310-9050$ & \\
\hline 70 & $11280-11190$ & \\
\hline 75 & $13110-12850$ & \\
\hline 90 & $19080-18140$ & \\
\hline 100 & $20830-20370$ & \\
\hline 150 & $24777-25537$ & \\
\hline 210 & $26023-26764$ & \\
\hline \multicolumn{3}{|c|}{ MV3 } \\
\hline 10 & $3570-3390$ & \multirow{3}{*}{$\begin{array}{l}\text { Sedimento } \\
\text { orgânico }\end{array}$} \\
\hline 120 & $39695-41584$ & \\
\hline 215 & $31903-32434$ & \\
\hline
\end{tabular}

\subsection{Taxas de sedimentação}

As taxas de sedimentação dos intervalos datados dos testemunhos MV1 e MV2 encontram-se listadas na Tabela 3. Elas variam de 0,0016 a 0,0165 $\mathrm{cm} / \mathrm{ano}$, com média de 0,0059 cm/ano, em MV1, e de 0,0024 a 0,0481 cm/ano, com média de $0,0087 \mathrm{~cm} / a n o$, em MV2.

Em ambos os testemunhos, a ordem de grandeza de taxa de sedimentação dominante, por intervalo, é a de $10^{-3} \mathrm{~cm} / a n$. Magnitudes maiores, de $10^{-2} \mathrm{~cm} /$ ano, ocorrem na metade inferior (100 a $210 \mathrm{~cm}$ ) de MV2 e no meio da metade superior de ambas as colunas (intervalo de profundidade de 10 a $80 \mathrm{~cm}$, em MV1, e de 40 a $70 \mathrm{~cm}$, em MV2). O aumento relativo da taxa de sedimentação 
na metade inferior da coluna sedimentar evidente em MV2 observa-se também, ainda que em valores bem menores, em MV1.

A ordem de grandeza dos intervalos de tempo comparados na Tabela 3 é sempre de milhares de anos, exceto no trecho entre 80 e $110 \mathrm{~cm}$ de MV1, onde se têm intervalos de tempo uma magnitude acima (mais de uma dezena de milhares de anos). Em vista disso, as diferenças encontradas entre os intervalos quanto a taxa deposicional não devem se relacionar com o efeito chamado por Korvin (1992) de "paradoxo da taxa de sedimentação", segundo o qual, quanto menor a espessura e o intervalo de tempo envolvidos, menor a probabilidade de hiatos deposicionais e, portanto, maior a taxa de sedimentação registrada (Sadler, 1981; Korvin, 1992; Ager, 1993). A única exceção são as taxas muito baixas encontradas no trecho de 80 a $110 \mathrm{~cm}$ em MV1, cujo intervalo de tempo é muito mais longo que os demais (quase 20 mil anos). Isto significa que as taxas comparativamente elevadas mencionadas no parágrafo anterior possuem, muito provavelmente, significado em termos de aumento no volume do suprimento sedimentar, e podem ser assim interpretadas.

As taxas de sedimentação mais elevadas em MV2 de que em MV1 são compatíveis com sua posição mais distal (a jusante), no sistema de drenagem envolvido. A taxa de sedimentação mais elevada de MV1 ocorre no meio da metade superior da coluna sedimentar (base da fácies mais grossa), enquanto em MV2 ela se encontra nos $60 \mathrm{~cm}$ inferiores, correlatos a fácies 1 (lama arenosa média a muito fina, também a mais grossa da coluna). Esta diferença na posição estratigráfica relativa dos maiores valores de taxa de sedimentação, por coluna, deve-se ao contraste de sucessão faciológica entre elas. Em ambas as colunas, porém, a maior taxa incide em fácies mais arenosa e à qual se atribui maior influência de aporte de canal fluvial, ou seja, caráter mais proximal em relação a este canal (de acordo com a interpretação de fácies preliminar apresentada no item 5.1).

Um ponto em comum em relação à variação das taxas de sedimentação em MV1 e MV2 é a existência de dois ciclos superpostos de decréscimo destas taxas para cima. Estes ciclos não possuem idades iguais nas duas colunas e, desse modo, não devem possuir controle por mudanças regionais de ordem tectônica ou climática. A hipótese mais provável, portanto, é que eles reflitam 
controle faciológico local, como reativação da influência do canal ou do aporte sedimentar a partir de encostas, seja esse controle autogênico (meandramentos, atalhos, avulsões) seja induzido por aumento episódico de precipitação (fluxos de massa).

Tabela 3- Taxas de sedimentação máximas e minimas, por intervalo, calculadas com base nas idades calibradas dos testemunhos MV1, MV2 e MV3

\begin{tabular}{|c|c|c|c|c|}
\hline \multicolumn{5}{|c|}{ MV1 } \\
\hline \multirow[t]{2}{*}{$\begin{array}{c}\text { Intervalo } \\
\text { vertical }(\mathbf{c m})\end{array}$} & \multirow[t]{2}{*}{$\begin{array}{c}\text { Duração } \\
\text { mínima (anos) }\end{array}$} & \multirow[t]{2}{*}{$\begin{array}{c}\text { Duração } \\
\text { máxima (anos) }\end{array}$} & \multicolumn{2}{|c|}{$\begin{array}{c}\text { Taxa de sedimentação } \\
\text { (cm/ano) }\end{array}$} \\
\hline & & & Máxima & Mínima \\
\hline $0-5$ & 1880 & 2060 & 0,0027 & 0,0024 \\
\hline $5-10$ & 1330 & 1500 & 0,0038 & 0,0033 \\
\hline $10-80$ & 4230 & 4380 & 0,0165 & 0,0160 \\
\hline $80-110$ & 17930 & 18820 & 0,0017 & 0,0016 \\
\hline $110-165$ & 7437 & 8195 & 0,0074 & 0,0067 \\
\hline $165-220$ & 5888 & 7715 & 0,0093 & 0,0071 \\
\hline $\begin{array}{l}\text { Sedimentação } \\
\text { média }\end{array}$ & 36815 & 38462 & 0,0059 & 0,0057 \\
\hline
\end{tabular}

\begin{tabular}{|c|c|c|c|c|}
\hline & \multicolumn{3}{|c|}{ MV2 } \\
\hline $\begin{array}{c}\text { Intervalo } \\
\text { vertical (cm) }\end{array}$ & $\begin{array}{c}\text { Duração } \\
\text { mínima (anos) }\end{array}$ & $\begin{array}{c}\text { Duração } \\
\text { máxima (anos) }\end{array}$ & \multicolumn{2}{|c|}{$\begin{array}{c}\text { Taxa de sedimentação } \\
\text { (cm/ano) }\end{array}$} \\
\cline { 4 - 5 } & & 2350 & 0,0046 & 0,0042 \\
\hline $0-10$ & 2150 & 7160 & 0,0044 & 0,0042 \\
\hline $10-40$ & 6900 & 2230 & 0,0140 & 0,0134 \\
\hline $40-70$ & 2140 & 1920 & 0,0030 & 0,0026 \\
\hline $70-75$ & 1660 & 6230 & 0,0028 & 0,0024 \\
\hline $75-90$ & 5290 & 2690 & 0,0045 & 0,0037 \\
\hline $90-100$ & 2230 & 5167 & 0,0113 & 0,0097 \\
\hline $100-150$ & 4407 & 1987 & 0,0481 & 0,0302 \\
\hline $150-210$ & 1246 & 24414 & 0,0087 & 0,0086 \\
\hline $\begin{array}{c}\text { Sedimentação } \\
\text { média }\end{array}$ & 23873 & & & \\
\hline
\end{tabular}

\begin{tabular}{|c|c|c|c|c|}
\hline \multicolumn{5}{|c|}{ MV3 } \\
\hline $\begin{array}{c}\text { Intervalo } \\
\text { vertical (cm) }\end{array}$ & $\begin{array}{c}\text { Duração } \\
\text { minima (anos) }\end{array}$ & $\begin{array}{c}\text { Duração } \\
\text { máxima (anos) }\end{array}$ & \multicolumn{2}{c|}{$\begin{array}{c}\text { Taxa de sedimentação } \\
\text { (cm/ano) }\end{array}$} \\
\cline { 3 - 5 } & Máxima & Mínima \\
\hline $0-10$ & 3390 & 3570 & 0,0029 & 0,0028 \\
\hline $10-120$ & 36305 & 38014 & 0,0030 & 0,0028 \\
\hline $120-215$ & 7261 & 9150 & 0,0130 & 0,0103 \\
\hline $\begin{array}{c}\text { Sedimentação } \\
\text { média }\end{array}$ & 28333 & 28864 & 0,0007 & 0,0007 \\
\hline
\end{tabular}




\subsection{Palinologia}

Os principais táxons identificados em Monte Verde encontram-se ilustrados nas estampas (I à XVII) anexo (I à VII) e listados, com suas respectivas ecologias, no Quadro 1.

Entre as árvores, os elementos associados à Floresta de Araucária são os mais representativos, com destaque para Drymis, Ilex e Podocarpus, gêneros que, em várias regiões, são encontrados em altitudes acima de 1500 $\mathrm{m}$ em florestas montanas. Os arbustos encontrados em Monte Verde também possuem distribuição preferencial em climas frios, enquanto as ervas das famílias Caryophylaceae e Valeriana ocorrem, igualmente, em regiões frias e de elevada altitude. As briófitas e pteridófitas que representam o registro vegetacional de Monte Verde ocupam preferencialmente áreas úmidas, nas margens de córregos. Entre as briófitas, o gênero mais bem representado na vegetação de Monte Verde é Anthoceros, também típico de faixas climáticas frias, onde ocorre preferencialmente na forma de pequenos tufos. Entre as pteridófitas, os esporos encontrados em maior concentração na região estudada são os pertencentes ao gênero arborescente Cyathea, que em diferentes áreas ocupa preferencialmente regiões altas, e Dicksonia, que ocorre ao longo de terrenos úmidos. As algas são representadas por Debarya e Zygnema, ambas indicativas de solos úmidos de regiões tropical, temperada ou fria.

Quadro 1- Principais táxons registrados nos testemunhos e respectivos habitats/ecologias, de acordo com Joly (1998) e Lorenzi (1992).

\begin{tabular}{|l|l|}
\hline \multicolumn{1}{|c|}{ Táxons } & \multicolumn{1}{c|}{ Habitat/Ecologia } \\
\hline ÁRVORES & $\begin{array}{l}\text { Árvores de pequeno porte encontradas em várzeas, com solo } \\
\text { fértil sempre úmido. }\end{array}$ \\
\hline Acrocomia & $\begin{array}{l}\text { Palmeiras que ocupam a margem de pântanos, ambientes } \\
\text { lacustres e terrenos brejosos de regiões tropicais e } \\
\text { subtropicais. }\end{array}$ \\
\hline Alchornea & $\begin{array}{l}\text { Árvores e ervas de vasta dispersão em áreas de altitudes } \\
\text { médias até altas. Habitam florestas pluviais atlânticas, } \\
\text { várzeas, margem de rios, solos úmidos, cerrados e florestas- } \\
\text { galeria. Desenvolvem-se em clima tropical e subtropical. }\end{array}$ \\
\hline
\end{tabular}




\begin{tabular}{|c|c|}
\hline Allagoptera & $\begin{array}{l}\text { Arvores, arbustos e trepadeiras que ocupam a margem de } \\
\text { pântanos, ambientes lacustres e terrenos brejosos de regióes } \\
\text { tropicais e subtropicais. }\end{array}$ \\
\hline Anacardium & $\begin{array}{l}\text { Árvores e subarbustos em formações florestais e campestres, } \\
\text { beira de rios, borda de mata, solos úmidos e campos. }\end{array}$ \\
\hline Araucaria & $\begin{array}{l}\text { Pinheiros isolados ou agrupados em capões de variadas } \\
\text { dimensões, presentes em florestas-galeria sob climas } \\
\text { tropicais de altitude, temperados e frios. }\end{array}$ \\
\hline Aspidosperma & $\begin{array}{l}\text { Plantas com hábito arbóreo e arbustivo, presentes em } \\
\text { florestas tropicais e temperadas. }\end{array}$ \\
\hline Caryocar & $\begin{array}{l}\text { Árvores com distribuição em zonas tropicais com campos e } \\
\text { florestas. }\end{array}$ \\
\hline Celastracea & $\begin{array}{l}\text { Árvores que ocupam várzeas aluviais e beira de córregos em } \\
\text { solos argilosos profundos de drenagem lenta, sub-bosques } \\
\text { das florestas de Araucaria nas margens de rios. }\end{array}$ \\
\hline Connarus & $\begin{array}{l}\text { Árvores pequenas, arbustos, trepadeiras ou lianas (cipós) de } \\
\text { grande porte. Gênero pantropical com } 8 \text { a } 100 \text { espécies sendo } \\
30 \text { de ocorrência no Brasil. }\end{array}$ \\
\hline Cordia & $\begin{array}{l}\text { Arvoretas, árvores altas e trepadeiras que ocupam a região de } \\
\text { cerrados e florestas, distribuindo-se numa faixa climática que } \\
\text { varia desde regiôes tropicais até áreas temperadas e frias. }\end{array}$ \\
\hline Croton & $\begin{array}{l}\text { Árvores e também algumas ervas de regiões de cerrados e } \\
\text { florestas serranas. Distribuem-se em regióes tropicais e } \\
\text { subtropicais. }\end{array}$ \\
\hline Drymis & $\begin{array}{l}\text { Arvores e arbustos das sub-copas de florestas temperadas. } \\
\text { Habitam ainda florestas serranas, onde a temperatura é mais } \\
\text { baixa, e florestas temperadas. }\end{array}$ \\
\hline Elizabetha & $\begin{array}{l}\text { Plantas lenhosas arbóreas e arbustivas com distribuição em } \\
\text { zonas tropicais com campos e florestas. }\end{array}$ \\
\hline Eugenia & $\begin{array}{l}\text { Árvores que ocupam florestas, matas abertas, florestas- } \\
\text { galeria e cerrados, com hábito arbustivo lenhoso ou de } \\
\text { arvoretas e árvores de grande porte. }\end{array}$ \\
\hline Euterpe & $\begin{array}{l}\text { Palmeira que ocupa a margem de pântanos, ambientes } \\
\text { lacustres e terrenos brejosos de regiões tropicais e } \\
\text { subtropicais. }\end{array}$ \\
\hline Lauraceae & $\begin{array}{l}\text { Arvoretas presentes em regiões de cerrados e florestas } \\
\text { distribuidas em zonas tropicais e subtropicais. }\end{array}$ \\
\hline Fragaria & $\begin{array}{l}\text { Árvores presentes em pântanos, brejos e terraços planos e } \\
\text { abertos, próximos a rios, em regióes temperadas. }\end{array}$ \\
\hline
\end{tabular}




\begin{tabular}{|c|c|}
\hline Gouania & $\begin{array}{l}\text { Plantas arbóreas de distribuição marcada em regiões } \\
\text { temperadas, incluindo matas mais abertas situadas sobre } \\
\text { solos úmidos. }\end{array}$ \\
\hline Hedyosmum & $\begin{array}{l}\text { Arvoretas e arbustos de florestas tropicais, pluviais e matas } \\
\text { de galeria. }\end{array}$ \\
\hline Ilex & $\begin{array}{l}\text { Árvores de matas abertas, florestas fechadas (sempre } \\
\text { verdes), florestas serranas e cerrados, adaptadas a climas } \\
\text { tropical, subtropical e temperado; encontram-se também } \\
\text { como arvoretas. }\end{array}$ \\
\hline Jacaranda & $\begin{array}{l}\text { Arvores e arbustos que se distribuem nas regióes tropicais, } \\
\text { ocupando campos e matas. }\end{array}$ \\
\hline Maprounea & $\begin{array}{l}\text { Arvoretas e/ou arbustos característicos de diversas } \\
\text { formações vegetais com maior freqüência na mata pluvial } \\
\text { perenifólia e na floresta semidescidual. Ocorrem } \\
\text { preferencialmente em formações secundárias e primárias de } \\
\text { terrenos argilosos bem drenados, de aclives suaves e de boa } \\
\text { fertilidade. }\end{array}$ \\
\hline Matayba & $\begin{array}{l}\text { Arvoretas e arbustos lenhosos de regióes tropicais e } \\
\text { subtropicais. Habitam solos úmidos das planícies aluviais e } \\
\text { florestas. }\end{array}$ \\
\hline Maytenus & $\begin{array}{l}\text { Arvores de habitat secundário, ocupando várzeas aluviais e } \\
\text { beira de córregos em solos argilosos profundos de drenagem } \\
\text { lenta, sub-bosques das florestas de Araucaria nas margens } \\
\text { de rios. }\end{array}$ \\
\hline Melastomataceae & $\begin{array}{l}\text { Árvores e arbustos que ocupam matas, campos, brejos, } \\
\text { bordas de matas, serras e cerrados. Incluem plantas de } \\
\text { hábito arbustivo e herbáceo, trepadeiras, arvoretas e epifitas } \\
\text { de zonas tropicais e subtropicais. }\end{array}$ \\
\hline Miconia & $\begin{array}{l}\text { Plantas de hábito arbustivo, herbáceo, trepadeiras, arvoretas } \\
\text { e epifitas de zonas tropicais e subtropicais. Ocupam campos, } \\
\text { brejos, bordas de matas, serras e cerrados. }\end{array}$ \\
\hline Myriocarpus & Arvoretas que ocupam florestas tropicais. \\
\hline Myristicaceae & $\begin{array}{l}\text { Árvores ou arbustos de florestas pluviais tropicais e } \\
\text { subtropicais, geralmente abaixo de } 1000 \mathrm{~m} \text { ou ultrapassando } \\
2000 \mathrm{~m} \text { de altitude. }\end{array}$ \\
\hline Myricia & $\begin{array}{l}\text { Plantas de hábito arbustivo lenhoso, arvoretas ou árvores de } \\
\text { grande porte, em florestas, matas abertas, florestas galeria e } \\
\text { cerrado. }\end{array}$ \\
\hline
\end{tabular}




\begin{tabular}{|c|c|}
\hline Myrsine & $\begin{array}{l}\text { Arvoretas e arbustos lenhosos que ocupam cerrados e } \\
\text { florestas tropicais pluviais em climas tropicais e subtropicais. }\end{array}$ \\
\hline Myrtaceae & $\begin{array}{l}\text { Plantas de hábito arbustivo lenhoso ou arvoretas e árvores de } \\
\text { grande porte, em florestas, matas abertas, florestas galeria e } \\
\text { cerrados. }\end{array}$ \\
\hline Pouteria & $\begin{array}{l}\text { Com hábito arbóreo, ocupam florestas pluviais atlânticas, ao } \\
\text { longo de rios, encostas e cerrados de regiões tropicais }\end{array}$ \\
\hline Peltophorum & $\begin{array}{l}\text { Gênero de árvores da floresta Ombrófila Densa e da Floresta } \\
\text { Estacional Semi-decidual }\end{array}$ \\
\hline Podocarpus & $\begin{array}{l}\text { Árvores presentes em florestas pluviais, tropicais e florestas } \\
\text { serranas, sob clima tropical e temperado. }\end{array}$ \\
\hline Prunus & $\begin{array}{l}\text { Árvores presentes em pântanos, brejos e terraços planos e } \\
\text { abertos próximos a rios, em regiões temperadas. }\end{array}$ \\
\hline Psidium & $\begin{array}{l}\text { Plantas de hábito arbustivo lenhoso ou de arvoretas e árvores } \\
\text { de grande porte, em florestas, matas abertas, florestas galeria } \\
\text { e cerrados. }\end{array}$ \\
\hline Rubiaceae & $\begin{array}{l}\text { Arvores, arbustos e ervas ocupantes de florestas, campos e } \\
\text { cerrados em faixa climática tropical e temperada. }\end{array}$ \\
\hline Rutaceae & $\begin{array}{l}\text { Plantas subarbustivas ou arbóreas de matas, florestas } \\
\text { deciduas, florestas de altitude, lugares úmidos e bordas de } \\
\text { mata, em regiões tropicais e subtropicais. }\end{array}$ \\
\hline Scutia & $\begin{array}{l}\text { Arbustos ou árvores com copa esférica e densa, presentes } \\
\text { em clima temperado, associados a solos úmidos de regiões } \\
\text { serranas. }\end{array}$ \\
\hline Symplocos & $\begin{array}{l}\text { Plantas de hábito arbóreo, ocorrem em terras altas, matas } \\
\text { ciliares, florestas de altitude, cerrados e florestas serranas, } \\
\text { com distribuição climática tropical e subtropical. }\end{array}$ \\
\hline Tabebuia & $\begin{array}{l}\text { Plantas lenhosas, arbustivas ou arbóreas e trepadeiras, } \\
\text { ocupando campos e matas, em regióes tropicais. }\end{array}$ \\
\hline Vernonia & $\begin{array}{l}\text { Ervas, arbustos baixos ou lenhosos, arvoretas e árvores, (este } \\
\text { último hábito, corrente na Floresta de Araucária de Monte } \\
\text { Verde). Caracterizam cerrados e florestas atlânticas com } \\
\text { climas tropical, subtropical e temperado. }\end{array}$ \\
\hline \multicolumn{2}{|l|}{ ARBUSTOS } \\
\hline Agarista & $\begin{array}{l}\text { Arbustos lenhosos de clima tropical, temperado e frio. } \\
\text { Ocupam brejos e terrenos alagadiços em áreas com solos } \\
\text { ácidos de regiões montanhosas. Podem ocupar margens de } \\
\text { pântanos e turfeiras. }\end{array}$ \\
\hline
\end{tabular}




\begin{tabular}{|c|c|}
\hline Chamaesyce & $\begin{array}{l}\text { Arbustos e ervas cosmopolitas, habitantes de regiões de } \\
\text { campos. }\end{array}$ \\
\hline Fabaceae & $\begin{array}{l}\text { Hábito herbáceo, arbustivo e arbóreo; ocupam diferentes } \\
\text { formações vegetais. }\end{array}$ \\
\hline Heteropteris & $\begin{array}{l}\text { Ervas e trepadeiras presentes em cerrados e florestas } \\
\text { tropicais. Distribuem-se em faixa climática tropical a } \\
\text { subtropical. }\end{array}$ \\
\hline Menispermaceae & $\begin{array}{l}\text { Trepadeiras ou subarbustos, principalmente, ocupando zonas } \\
\text { temperadas. }\end{array}$ \\
\hline Piperaceae & $\begin{array}{l}\text { Plantas com hábito herbáceo, trepadeiras, raramente árvores } \\
\text { e, em especial, arbustos. }\end{array}$ \\
\hline Sapindaceae & $\begin{array}{l}\text { Arvoretas e arbustos lenhosos de regiões tropicais e } \\
\text { subtropicais, onde habitam solos úmidos das planícies aluviais } \\
\text { e florestas. }\end{array}$ \\
\hline \multicolumn{2}{|l|}{ ERVAS } \\
\hline \multicolumn{2}{|l|}{ Terrestres } \\
\hline Alternanthera & $\begin{array}{l}\text { Ervas que ocupam faixa climática de tropical a subtropical, e } \\
\text { habitam ambientes secos, aquáticos e até cerrados. }\end{array}$ \\
\hline Amaryllidaceae & Ervas de regiões tropicais e subtropicais. \\
\hline Apiaceae & Ervas de regiões subtropicais \\
\hline Asteraceae & $\begin{array}{l}\text { Ervas, arbustos baixos ou lenhosos, arvoretas e árvores; } \\
\text { caracterizam cerrados e florestas atlânticas com climas } \\
\text { tropical, subtropical e temperado. }\end{array}$ \\
\hline Begonia & $\begin{array}{l}\text { De hábito herbáceo, às vezes arbustivo, e está presente em } \\
\text { matas úmidas, em regiões tropicais e subtropicais. }\end{array}$ \\
\hline Borreria & $\begin{array}{l}\text { Ervas ocupantes de campos e cerrados em faixa climática } \\
\text { tropical e temperada. Podem ainda aparecer como arbustos } \\
\text { ou subarbustos. }\end{array}$ \\
\hline Bromeliaceae & $\begin{array}{l}\text { Herbáceas, epífitas e terrestres, ocorrendo em zonas } \\
\text { tropicais. }\end{array}$ \\
\hline Caryophylaceae & $\begin{array}{l}\text { Plantas herbáceas presente em regiões de clima frio e altas } \\
\text { altitudes. }\end{array}$ \\
\hline Chenopodium & $\begin{array}{l}\text { Ervas, arbustos, árvores e trepadeiras de campos, que se } \\
\text { distribuem em regiões tropicais, temperadas e frias. }\end{array}$ \\
\hline Convolvulaceae & $\begin{array}{l}\text { Ervas, arbustos, arvoretas e, em alguns casos, trepadeiras, } \\
\text { habitando cerrados e matas, em regiões tropicais, } \\
\text { subtropicais e temperadas. }\end{array}$ \\
\hline Cuphea & Plantas de hábito variado, desde ervas e arbustos até \\
\hline
\end{tabular}




\begin{tabular}{|c|c|}
\hline & $\begin{array}{l}\text { árvores, com ampla distribuição nos trópicos e subtrópicos, } \\
\text { sendo comuns nos campos e matas. }\end{array}$ \\
\hline Cyperus & $\begin{array}{l}\text { De hábito raramente arbustivo, e comumente herbáceo, } \\
\text { ocorrem em ambientes úmidos como brejos e áreas } \\
\text { alagadiças, pântanos e turfeiras de zonas tropicais, } \\
\text { temperadas e frias. }\end{array}$ \\
\hline Eryngium & $\begin{array}{l}\text { Gênero disperso nas regiões temperadas, seus } \\
\text { representantes são arbóreos, ocupantes de campos, brejos, } \\
\text { ambientes lacustres e pântanos. }\end{array}$ \\
\hline Pfaffia & $\begin{array}{l}\text { Ervas e trepadeiras, com distribuição cosmopolita, } \\
\text { adaptando-se ao clima tropical, subtropical e temperado. }\end{array}$ \\
\hline Poaceae & $\begin{array}{l}\text { Ervas cosmopolitas em regiões de florestas. Ocupam locais } \\
\text { úmidos como pântanos e turfeiras. São abundantes em quase } \\
\text { todos os ecossistemas. Dentre elas, incluem-se bambus que } \\
\text { podem ocorrer dentro de florestas úmidas. }\end{array}$ \\
\hline Tournefortia & Ervas rudeirais de hábito pioneiro. \\
\hline Valeriana & $\begin{array}{l}\text { São plantas herbáceas, trepadeiras distribuídas em regiões } \\
\text { montanhosas, bosques e regiões úmidas, desde os níveis } \\
\text { mais baixos até } 2000 \mathrm{~m} \text { de altitude. }\end{array}$ \\
\hline \multicolumn{2}{|l|}{ Aquáticas } \\
\hline Hydrocotyle & $\begin{array}{l}\text { Gênero disperso nas regiões temperadas, seus } \\
\text { representantes são arbóreos, ocupantes de campos, brejos, } \\
\text { lagos e pântanos. }\end{array}$ \\
\hline Polygala & Ervas aquáticas com ampla distribuição geográfica. \\
\hline Utricularia & $\begin{array}{l}\text { Plantas herbáceas, aquáticas, presentes em terrenos úmidos } \\
\text { e brejos distribuídos no mundo todo. }\end{array}$ \\
\hline \multicolumn{2}{|l|}{ ESPOROS } \\
\hline \multicolumn{2}{|l|}{ Bryophyta } \\
\hline Anthoceros & $\begin{array}{l}\text { Habitam margens de córregos, campos úmidos e interior de } \\
\text { florestas. Formam pequenos tufos distribuídos em faixas } \\
\text { climáticas frias. }\end{array}$ \\
\hline Phaeoceros & $\begin{array}{l}\text { Habitam margem de córregos, campos úmidos onde exista } \\
\text { cobertura vegetal desenvolvida para proteção, solos } \\
\text { orgânicos encharcados, bordas de pântanos e turfeiras. } \\
\text { Formam pequenos tufos. São higrófitas, terrícolas e } \\
\text { acidófilas, de zonas tropicais, temperadas e frias. }\end{array}$ \\
\hline \multicolumn{2}{|l|}{ Pteridophytas } \\
\hline Anemia & Ocupam ambientes abertos e bem drenados, florestas \\
\hline
\end{tabular}




\begin{tabular}{|c|c|}
\hline & $\begin{array}{l}\text { abertas e tropicais, margens de córegos e encostas. } \\
\text { Possuem hábito terrestre distribuindonse em zonas tropicais e } \\
\text { temperadas. }\end{array}$ \\
\hline Blechnum & $\begin{array}{l}\text { Plantas epífitas, ocupando forestas ao longo de rios, } \\
\text { pântanos e sedimentos fluviais, durante o Quaternário, em } \\
\text { ambientes tropicais e subtropicais; abundantes em zonas de } \\
\text { mata. }\end{array}$ \\
\hline Cyathea & $\begin{array}{l}\text { De hábitos arborescentes, ocupam o interior de matas, } \\
\text { preferencialmente em alto de encostas e topo de elevações. }\end{array}$ \\
\hline Dicksonia & $\begin{array}{l}\text { Ervas arborescentes geralmente associadas à floresta de } \\
\text { Araucaria. Podem ocorrer ao longo de córregos e terrenos } \\
\text { úmidos. }\end{array}$ \\
\hline Isoëtes & $\begin{array}{l}\text { Planta herbácea de locais brejosos ou riachos, podendo viver } \\
\text { submersas. }\end{array}$ \\
\hline Lycopodium & $\begin{array}{l}\text { Possuem hábito epifita, terrestre e rupestre em florestas } \\
\text { úmidas e montanhas tropicais. Podem ocupar, ainda, chão de } \\
\text { florestas e aparecerem por entre a vegetaçäo arbustiva e na } \\
\text { margem de pântanos }\end{array}$ \\
\hline Lygodium & $\begin{array}{l}\text { De hábito terrestre, distribuem-se em zonas tropicais e } \\
\text { temperadas, onde ocupam ambientes abertos e bem } \\
\text { drenados, florestas abertas, margens de córregos e encostas. }\end{array}$ \\
\hline Polypodiaceae & $\begin{array}{l}\text { Plantas epifitas, saprófitas, terrestres e rupestres que ocupam } \\
\text { florestas tropicais de terras baixas, florestas de montanhas, } \\
\text { matas, solos orgånicos e regiões arbustivas; adaptadas a } \\
\text { faixas climáticas tropicais a subtropicais. }\end{array}$ \\
\hline Polypodium & $\begin{array}{l}\text { Plantas epifitas, saprófitas, terrestres e rupestres que ocupam } \\
\text { florestas tropicais de terras baixas, florestas de montanhas, } \\
\text { matas, solos orgânicos e regiôes arbustivas. Adaptadas a } \\
\text { faixas climáticas tropicais a subtropicais. }\end{array}$ \\
\hline Pteris & $\begin{array}{l}\text { Plantas epifitas, terrestres e rupestres, habitam florestas } \\
\text { úmidas ao longo de córregos, florestas-galeria e locais } \\
\text { abertos e arbustivos. }\end{array}$ \\
\hline \multicolumn{2}{|l|}{ Algas } \\
\hline Debarya & $\begin{array}{l}\text { Algas filamentosas de água doce, rasa e sobre silicíferos; } \\
\text { habitam pântanos rasos, solos encharcados e úmidos, em } \\
\text { faixa climática tropical, temperada e fria. }\end{array}$ \\
\hline Zgnema & $\begin{array}{l}\text { Algas filamentosas de água doce, salobra e solos úmidos, } \\
\text { habitantes de pântanos rasos, solos encharcados e úmidos } \\
\text { em faixas climáticas tropical, temperada e fria. }\end{array}$ \\
\hline
\end{tabular}




\subsubsection{Análise quantitativa de palinomorfos}

Os palinodiagramas de concentração referentes aos testemunhos MV1 e MV2 (Figuras 21 a 28) foram agrupados em: árvores; arbustos e ervas (aquáticas e terrestres); esporos e algas; e soma total dos táxons.

As análises interpretativas basearam-se nos gráficos de concentração, por serem estes os de maior representatividade sob o ponto de vista estatístico.

\section{a) Testemunho MV1}

Dois intervalos principais foram reconhecidos no testemunho MV1, com base nos resultados de palinologia. O primeiro intervalo compreende as profundidades de 230 a $110 \mathrm{~cm}$, com datações de 38695 - 40522 anos cal A.P., em $220 \mathrm{~cm}$, e $26260-25370$ anos cal A.P., em $110 \mathrm{~cm}$. Este limite superior do intervalo coincide com a mudança de fácies observada no testemunho, de lama com areia fina a média, abaixo, para lama com areia fina a grossa, acima. Os elementos arbóreos encontram-se bem representados no intervalo por Araucaria, llex, Jacaranda, Melastomataceae, Myrtaceae, Podocarpus, Rubiaceae, Symplocos, Tabebuia e Vernonia. A concentração máxima de árvores atinge 7000 grãos por $\mathrm{cm}^{3}$ na profundidade de $225-215 \mathrm{~cm}$, onde estão bem representadas pelos gêneros Maytenus e Myrcia.

Os arbustos apresentam concentração mínima de 250 grãos por $\mathrm{cm}^{3}$, na profundidade de $145 \mathrm{~cm}$, e máxima de cerca de 9000 grãos por $\mathrm{cm}^{3}$, na profundidade de $160 \mathrm{~cm}$ (com idade obtida de 32807 - 33565 anos cal A.P. em $165 \mathrm{~cm})$. Os elementos mais bem representados são os das famílias Convolvulaceae e Piperaceae. Entre as ervas, destacam-se, pela maior concentração, Borreria, com 1700 grãos por $\mathrm{cm}^{3}$, e Utricularia, com cerca de 900 grãos por $\mathrm{cm}^{3}$, ambas na profundidade de $160 \mathrm{~cm}$.

Ainda no intervalo de $230 \mathrm{~cm}$ a $110 \mathrm{~cm}$ de profundidade, a concentração minima de esporos e algas é de $75 \mathrm{grãos} / \mathrm{cm}^{3}$ na profundidade de $210 \mathrm{~cm}$ e a máxima, de 1600 grãos $/ \mathrm{cm}^{3}$, com o gênero Zygnema, na profundidade de $165 \mathrm{~cm}$. Eles são bem representados ainda pelas Briófitas dos gêneros Anthoceros e 
Phaeoceros, e, em menor quantidade, pelas Pteridófitas Isoëtes e Selaginella. $\mathrm{Na}$ profundidade de $180 \mathrm{~cm}$, aparecem Polypodiaceae e Polypodium.

O segundo intervalo corresponde aos últimos $110 \mathrm{~cm}$, que em termos de idade estendem-se de 26260 - 25370 anos cal A.P. a menos de 2060 - 1880 anos cal A.P. (resultado de datação na profundidade de $5 \mathrm{~cm}$ ). Caracteriza-se pelo aumento, em relação ao intervalo anterior, na concentração dos elementos arbóreos, com destaque para Allagoptera, Araucaria, Drymis, llex. Myrtaceae, Podocarpus, Symplocos, Tabebuia e Vernonia, todos sempre presentes ao longo do intervalo. Os gêneros Aspidosperma, Jacaranda e Weimannia desaparecem nos últimos $80 \mathrm{~cm}$ de profundidade (idade de 7590 - 7440 anos cal A.P.), enquanto Cordia e Connarus aparecem nos últimos $60 \mathrm{~cm}$. O gênero Elizabetha apresenta concentração máxima de 1250 grãos por $\mathrm{cm}^{3}$ no intervalo entre 105-75 $\mathrm{cm}$ de profundidade, sendo o único registro deste gênero presente no testemunho. A família Bignoniaceae, que havia desaparecido no intervalo anterior, reaparece em $35 \mathrm{~cm}$ com concentração máxima de 1000 grãos por $\mathrm{cm}^{3}$.

Os arbustos atingem concentração máxima de 9000 grãos por $\mathrm{cm}^{3}$ com o gênero Hypolepis na profundidade de $20 \mathrm{~cm}$ e mínima de 50 grãos por $\mathrm{cm}^{3} \mathrm{em} 30$ $\mathrm{cm}$. O gênero Chamaesyce atinge 6000 grãos por $\mathrm{cm}^{3} \mathrm{em} 35 \mathrm{~cm}$ e Agarista 7000 grãos por $\mathrm{cm}^{3}$ em $45 \mathrm{~cm}$ de profundidade. Neste intervalo, o gênero Heteropteris e a família Sapindaceae possuem sua primeira ocorrência registrada, com 2500 e 3000 grãos por $\mathrm{cm}^{3}$, respectivamente. Nas profundidades de $85 \mathrm{~cm}$ e $30 \mathrm{~cm}$, as familias Fabaceae e Convolvulaceae desaparecem.

No que se refere às ervas, Asteraceae, Alternanthera, Borreria, Bromeliaceae e Eryngium estão bem representadas dentre as terrestres, com concentração mínima de cerca de 40 grãos por $\mathrm{cm}^{3}$ na profundidade de $110 \mathrm{~cm}$ e de 7000 grãos por $\mathrm{cm}^{3}$ acima de $90 \mathrm{~cm}$. As ervas aquáticas são representadas pelos gêneros Hydrocotyle e Polygala, o qual possui concentração máxima de 7000 grãos por $\mathrm{cm}^{3}$ na profundidade de $10 \mathrm{~cm}$, com idade de $3380-3210$ anos cal A.P.Os esporos de Cyathea, Diksonia, Phaeoceros, Polypodiaceae, Polypodium e Selaginella são os de maior concentração. A concentração máxima registrada foi Selaginella na profundidade de $15 \mathrm{~cm}$, com cerca de 400 grãos por $\mathrm{cm}^{3}$, e a mínima foi de Cyathea, na profundidade de $110 \mathrm{~cm}$, com cerca de 200 grãos por $\mathrm{cm}^{3}$. Na profundidade de $70 \mathrm{~cm}$, o gênero Pteris possui sua primeira 
ocorrência registrada no testemunho, alcançando concentração máxima de 4200 grãos por $\mathrm{cm}^{3}$ na profundidade de $35 \mathrm{~cm}$. Em $60 \mathrm{~cm}$, o gênero Anthoceros desaparece.

As algas Debarya e Zygnema estão bem representadas. Zygnema apresenta maior concentração, atingindo cerca de 1750 grãos por $\mathrm{cm}^{3}$ na profundidade de $95 \mathrm{~cm}$. Nos últimos 3500 anos cal A.P. (idade extrapolada a partir de datação calibrada), a concentração de ambas não ultrapassa 600 grãos por $\mathrm{cm}^{3}$. 


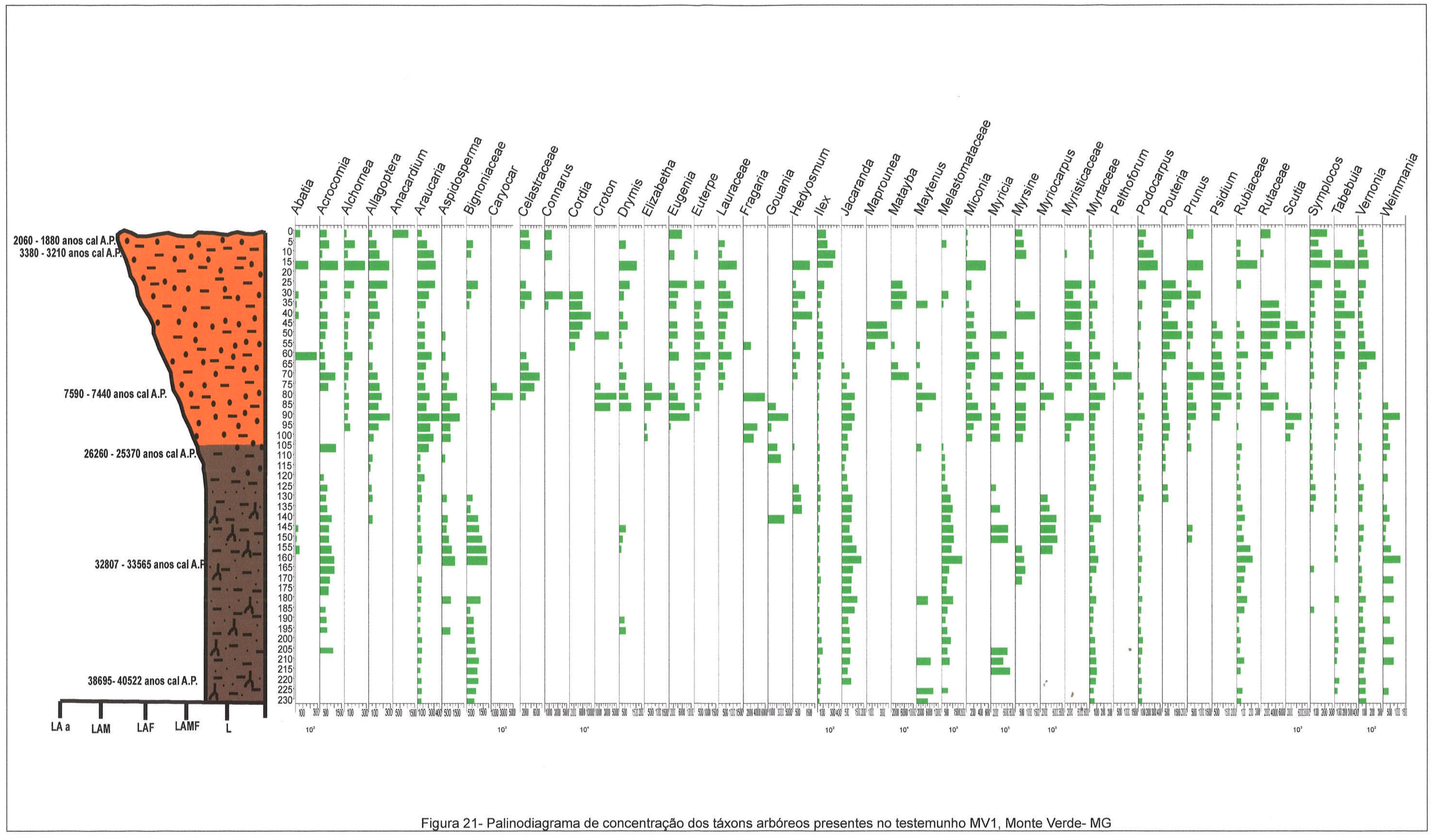




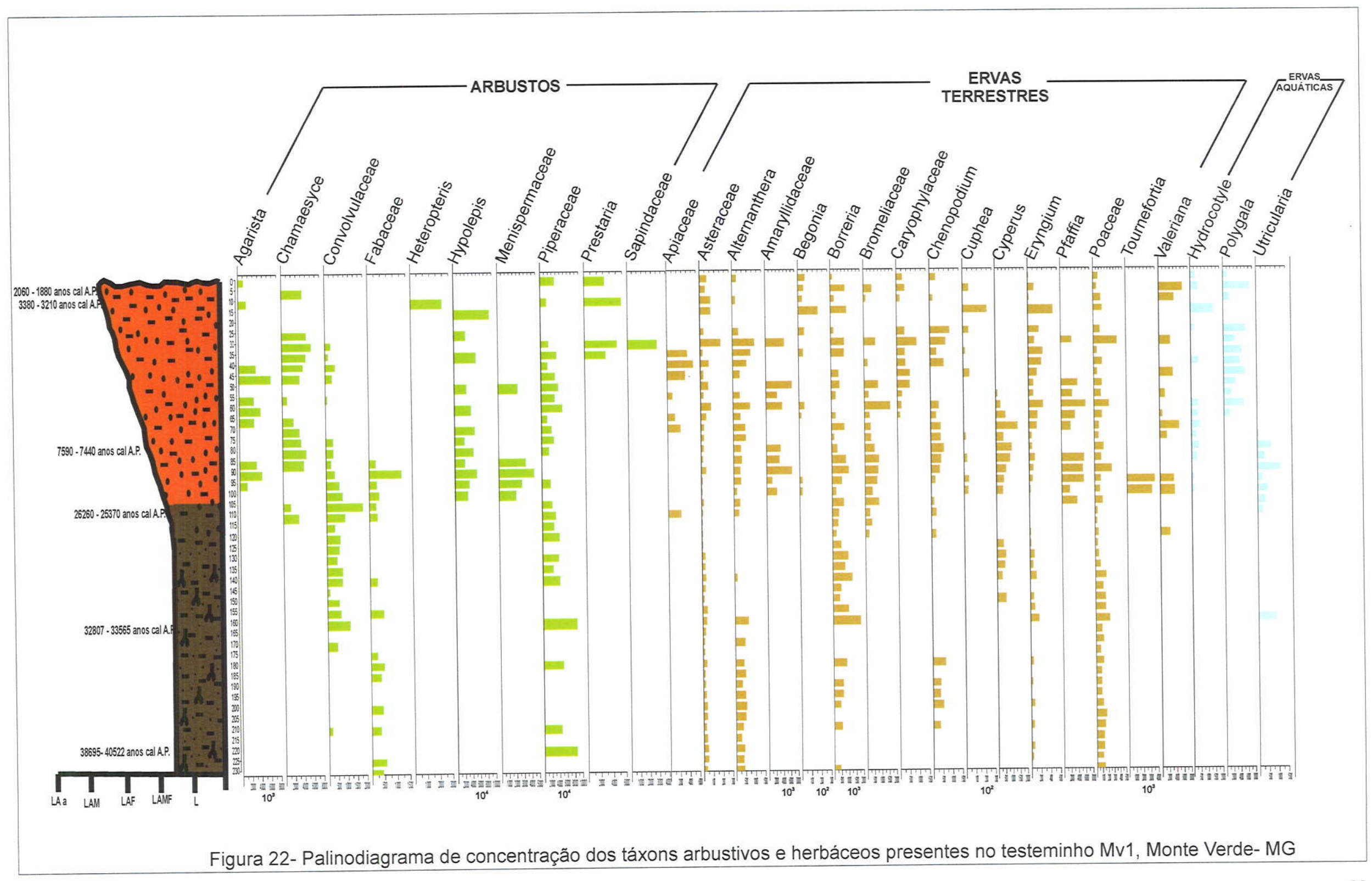




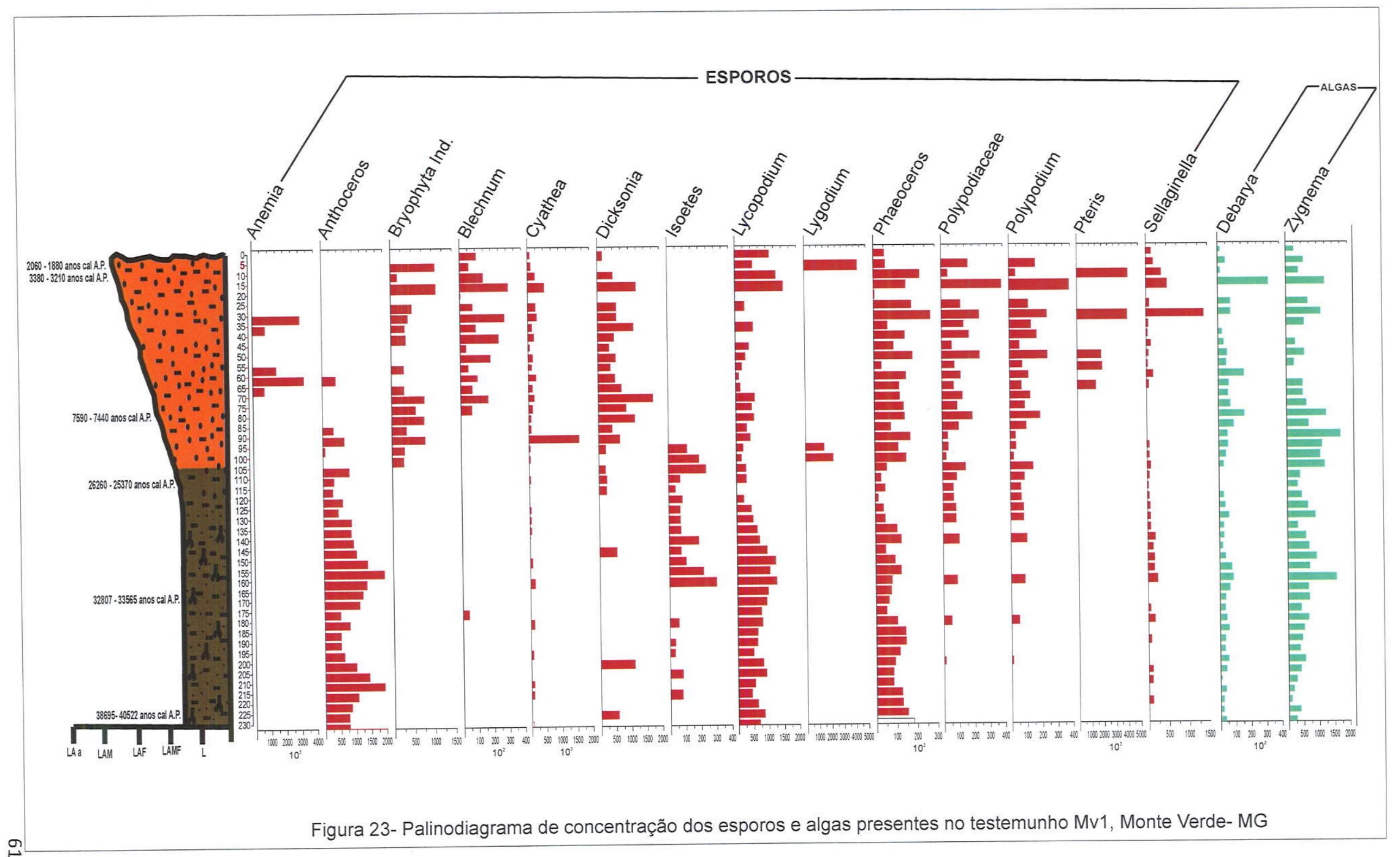




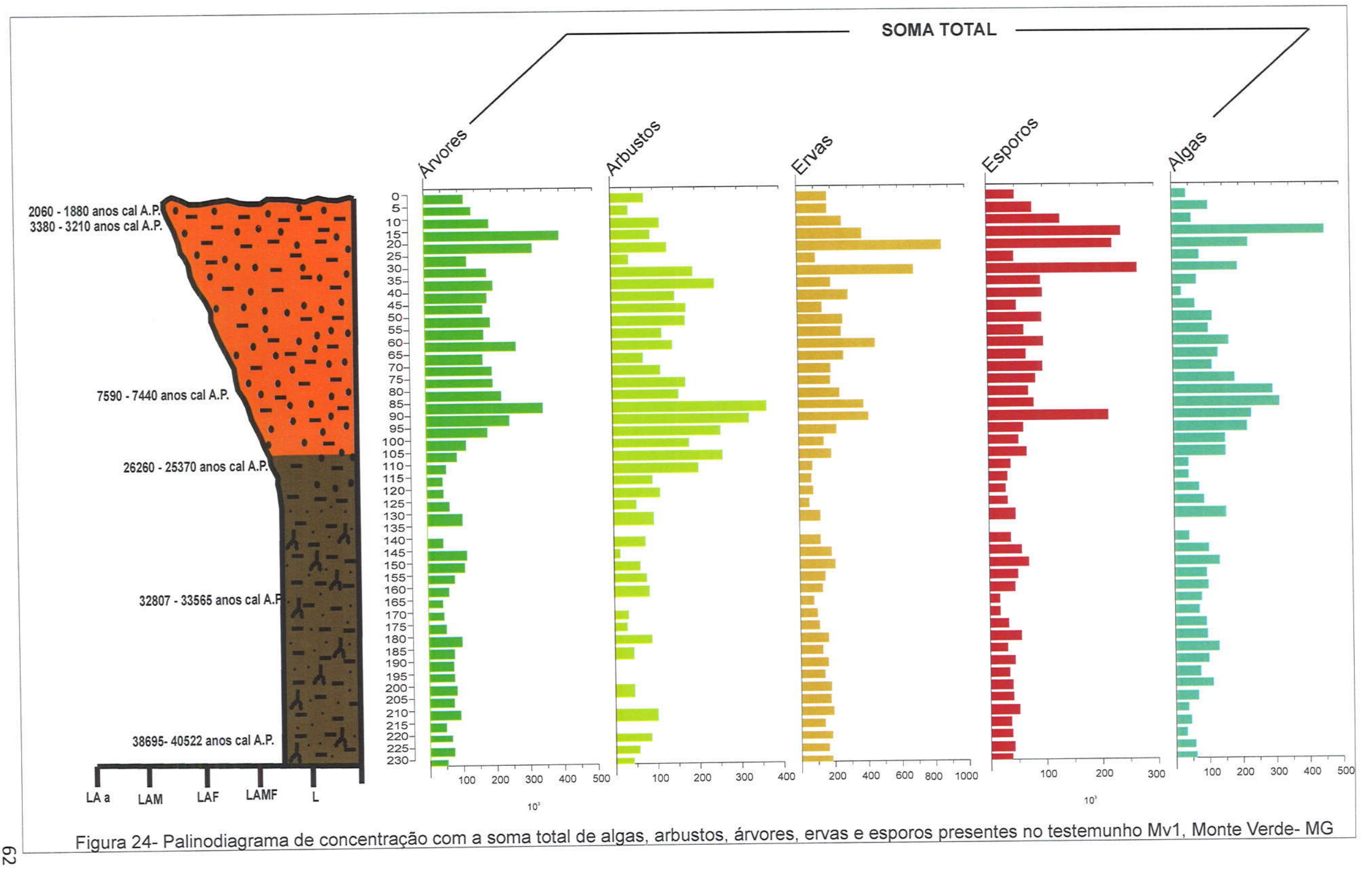




\section{b) Testemunho MV2}

Com base nos resultados de palinologia, o testemunho MV2 pode ser dividido em três intervalos principais. O primeiro destes intervalos compreende as profundidades de 210 a $110 \mathrm{~cm}$, correspondente ao periodo de tempo de 26764 26023 anos cal A.P. a mais de 20830 - 20370 anos cal A.P. (esta idade, obtida na profundidade de $100 \mathrm{~cm}$ ).

Seu topo coincide com a mudança de fácies mais evidente no testemunho (Figura 19), de areia fina a muito fina lamosa para lama arenosa. Este intervalo caracteriza-se pela diversidade de táxons representativos dos elementos arbóreos, com concentração máxima de 9000 grãos por $\mathrm{cm}^{3}$, nas profundidades de 225 e $210 \mathrm{~cm}$, e mínima de 50 grãos por $\mathrm{cm}^{3}$, em $150 \mathrm{~cm}$. Entre os táxons arbóreos, Araucaria, Ilex, Melastomataceae, Myrsine, Myrtaceae, Tabebuia e Weinmania estão representados em todo intervalo. As maiores concentrações são dos gêneros Fragaria e Eugenia, com 5000 grãos por $\mathrm{cm}^{3}$, nas profundidades de $225 \mathrm{~cm}$ e $145 \mathrm{~cm}$, respectivamente, e Cordia, com 9000 grãos por $\mathrm{cm}^{3}$, na profundidade $140 \mathrm{~cm}$.

Dentre os arbustos, Piperaceae atinge 9000 grãos por $\mathrm{cm}^{3}$ em $150 \mathrm{~cm}$ e Prestaria possui a mesma concentração em $160 \mathrm{~cm}$ de profundidade $(10 \mathrm{~cm}$ abaixo do intervalo datado em $24777-25537$ anos cal A.P.).

As ervas terrestres Chenopodium, Pfaffia e Valeriana são abundantes em todo intervalo, com concentração máxima de cerca de 8000 grãos por $\mathrm{cm}^{3}$ nas profundidades $160 \mathrm{~cm}, 180 \mathrm{~cm}$ e $220 \mathrm{~cm}$. Entre as aquáticas, a concentração mínima foi do gênero Hydrocotyle com 400 grãos por $\mathrm{cm}^{3}$ na profundidade de 230 $\mathrm{cm}$ e a máxima foi do gênero Polygala, com 9500 grãos por $\mathrm{cm}^{3}$ na profundidade de 220 com (idade anterior a 26023 - 26764 anos cal A.P., obtida na profundidade de $210 \mathrm{~cm}$ ). O gênero Utricularia, neste intervalo, só está representado na profundidade de $160 \mathrm{~cm}$, com concentração de 1000 grãos por $\mathrm{cm}^{3}$.

Os esporos são bem representados por Anthoceros, Cyathea, Dicksonia, Lycopodium, Polypodiaceae e Selaginella, e as algas por Debarya e Zygnema. Debarya mostra decréscimo na profundidade de $180 \mathrm{~cm}$, onde sua concentração não ultrapassa 50 grãos por $\mathrm{cm}^{3}$. Zygnema, com padrão de variação de 
concentração inverso ao de Debarya, atinge nesta profundidade cerca de 750 grãos por $\mathrm{cm}^{3}$.

O segundo intervalo compreende as profundidades de 110 a $25 \mathrm{~cm}$, com idades de 20830 - 20370 anos cal A.P. obtida em $100 \mathrm{~cm}$ e 5977 - 5779 anos A.P., no topo, esta última idade extrapolada a partir das datações calibradas obtidas em 40 e $10 \mathrm{~cm}$. Dentre os elementos arbóreos, destacam-se Allagoptera, Araucaria, Celastraceae, Connarus, Eugenia, Ilex, Matayba, Myriocarpus, Podocarpus e Rutaceae. A concentração média dos táxons varia de 6000 a 8000 grãos por $\mathrm{cm}^{3}$. A maior concentração está representada pelo gênero Cordia, que havia desaparecido no intervalo anterior. Ele reaparece na profundidade de $55 \mathrm{~cm}$ com cerca de 4000 grãos por $\mathrm{cm}^{3}$ e atinge 10000 grãos por $\mathrm{cm}^{3} \mathrm{em} 40 \mathrm{~cm}$, em sedimentos cuja idade é de 9310 - 9050 anos cal A.P. O gênero Caryocar só possui registro neste intervalo, entre 85 e $75 \mathrm{~cm}$, com concentração máxima de 5000 grãos por $\mathrm{cm}^{3} \mathrm{em} 80 \mathrm{~cm}$.

Os arbustos estão representados principalmente por Agarista, Chamaesyce e Convolvulaceae. O gênero Hypolepis possui concentração máxima de 7000 grãos por $\mathrm{cm}^{3}$ na profundidade de $35 \mathrm{~cm}$, cuja idade é mais nova que $9310-$ 9050 anos cal A.P., e, logo em seguida, em $25 \mathrm{~cm}$, sofre decréscimo para 2000 grãos por $\mathrm{cm}^{3}$. No final do intervalo, a $30 \mathrm{~cm}$, Sapindaceae aparece pela primeira vez no registro, com cerca de 3500 grãos por $\mathrm{cm}^{3}$. A familia Piperaceae está bem representada em todo o intervalo, com concentrações que variam de 1700 grãos por $\mathrm{cm}^{3}$, em $65 \mathrm{~cm}$, a 9500 grãos por $\mathrm{cm}^{3}$, em $15 \mathrm{~cm}$ (idade anterior a $2350-2150$ anos cal A.P., obtida em $10 \mathrm{~cm}$ ).

As ervas terrestres são bem representadas pelos gêneros Alternanthera, Borreria, Chenopodium, Eryngium e Valeriana. Apiaceae e Cuphea aparecem pela primeira vez no registro, nas profundidades de $110 \mathrm{~cm}$ e $100 \mathrm{~cm}$, respectivamente. Entre as ervas aquáticas, destaca-se Polygala, que reaparece a $65 \mathrm{~cm}$ de profundidade com concentração de 1500 grãos por $\mathrm{cm}^{3}$ enquanto Utricularia desaparece em $110 \mathrm{~cm}$ de profundidade.

A mesma representatividade observada no intervalo anterior pelos esporos é mantida aqui, com a presença, em grande concentração, de Blechnum, Bryophytas, Cyathea, Dicksonia. Lycopodium e Polypodiaceae. Na profundidade de $95 \mathrm{~cm}$, Isoetes desaparece, e, em $65 \mathrm{~cm}$, os gêneros Anemia e Pteris 
aparecem pela primeira vez no registro, com concentração de 3500 e 1500 grãos por $\mathrm{cm}^{3}$, respectivamente. As algas Debarya e Zgnema continuam bem representadas em todo intervalo, com concentração máxima de 1500 grãos por $\mathrm{cm}^{3}$.

O terceiro intervalo é o dos últimos $25 \mathrm{~cm}$, correspondentes a idades mais novas que 5977 - 5779 anos A.P. (data extrapolada). Neste intervalo, os elementos arbóreos continuam bem representados pelos táxons Araucaria, Ilex, Symplocos, Podocarpus e Vernonia. A Araucaria atinge o máximo de sua concentração, cerca de 500 grãos por $\mathrm{cm}^{3}$, na profundidade de $20 \mathrm{~cm}$.

Prestaria e Piperaceae são arbustos que mantêm sua concentração neste intervalo. O gênero Heteropteris tem sua primeira ocorrência registrada, com cerca de 3000 grãos por $\mathrm{cm}^{3}$. Entre as ervas terrestres, Asteraceae, Begonia e Borreria são os representantes com maior concentração. Hydrocotyle e Polygala continuam presentes, com pico nos últimos $5 \mathrm{~cm}$, onde Polygala atinge 8000 grãos por $\mathrm{cm}^{3}$.

Os esporos possuem grande oscilação em todo intervalo. Cyathea diminui gradativamente sua concentração em direção à superfície. Essa diminuição é acompanhada por Dicksonia, que desaparece em $5 \mathrm{~cm}$. Os esporos de Blechnum, Phaeoceros, Polypodiaceae e Polypodium mantêm sua concentração ao longo do intervalo.

Debarya e Zgnema também mantêm sua concentração, com pico a $15 \mathrm{~cm}$ de profundidade. 


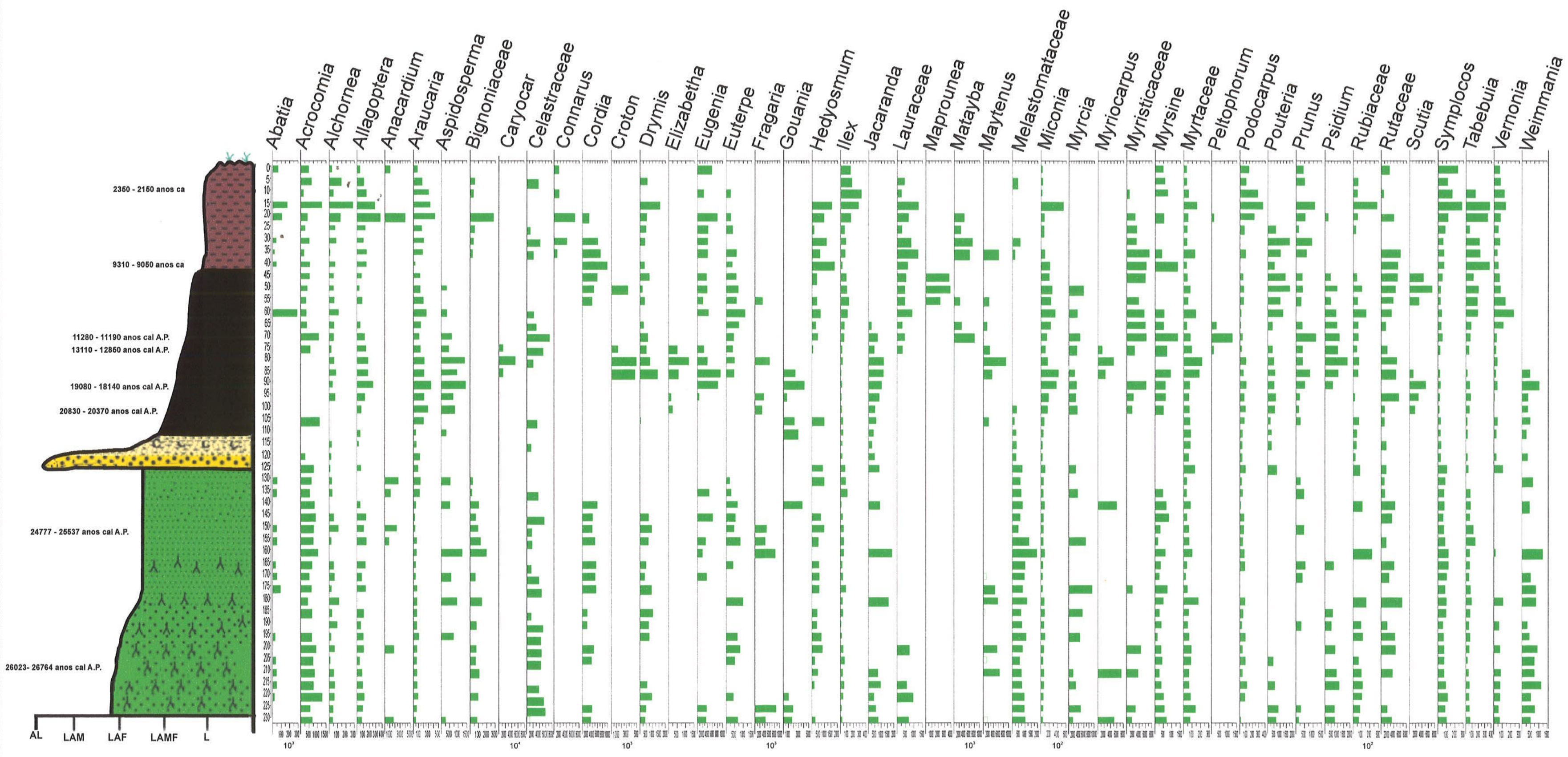

Figura 25- Palinodiagrama de concentração dos táxons arbóreos presentes no testemunho Mv2, Monte Verde- MG 


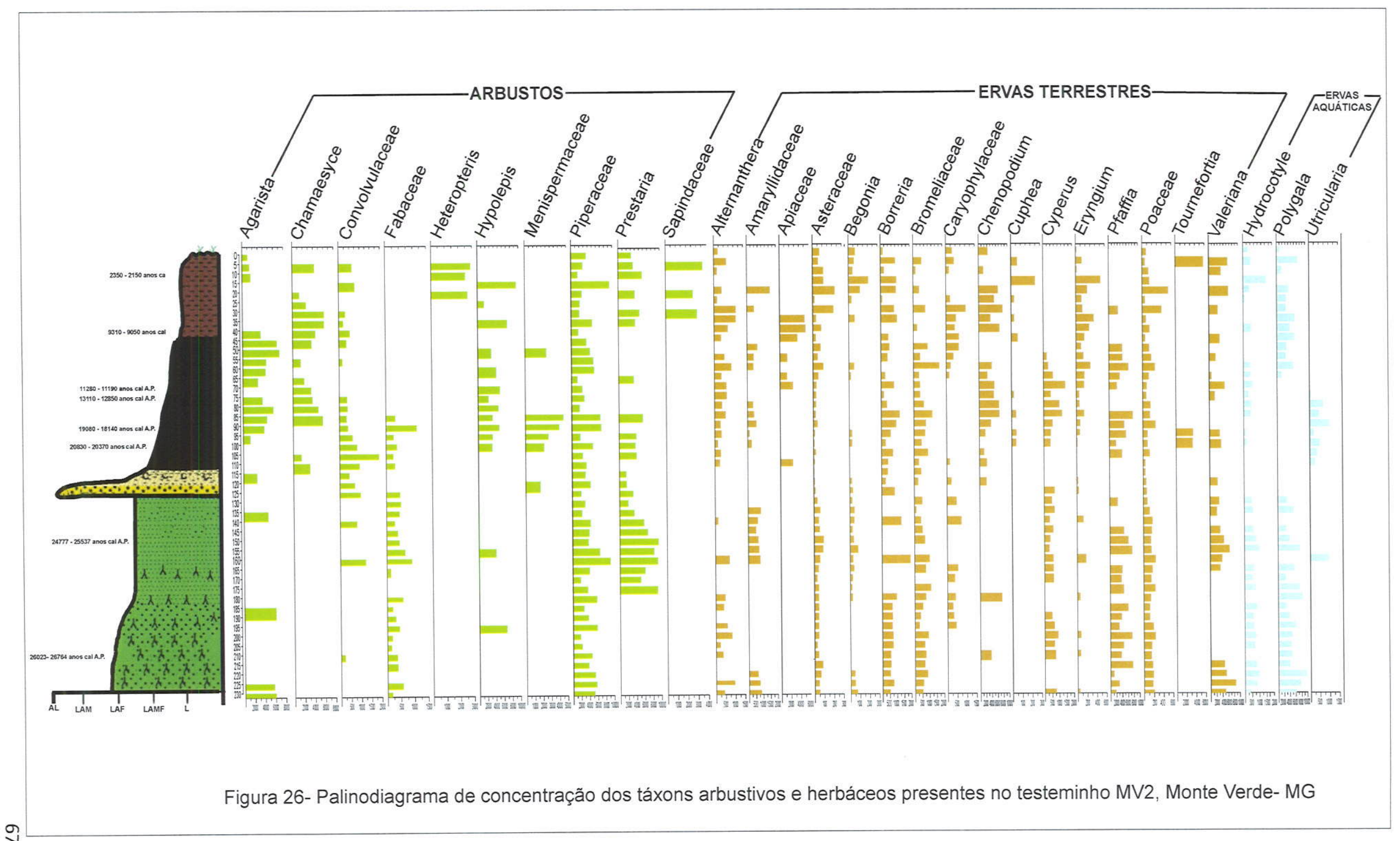




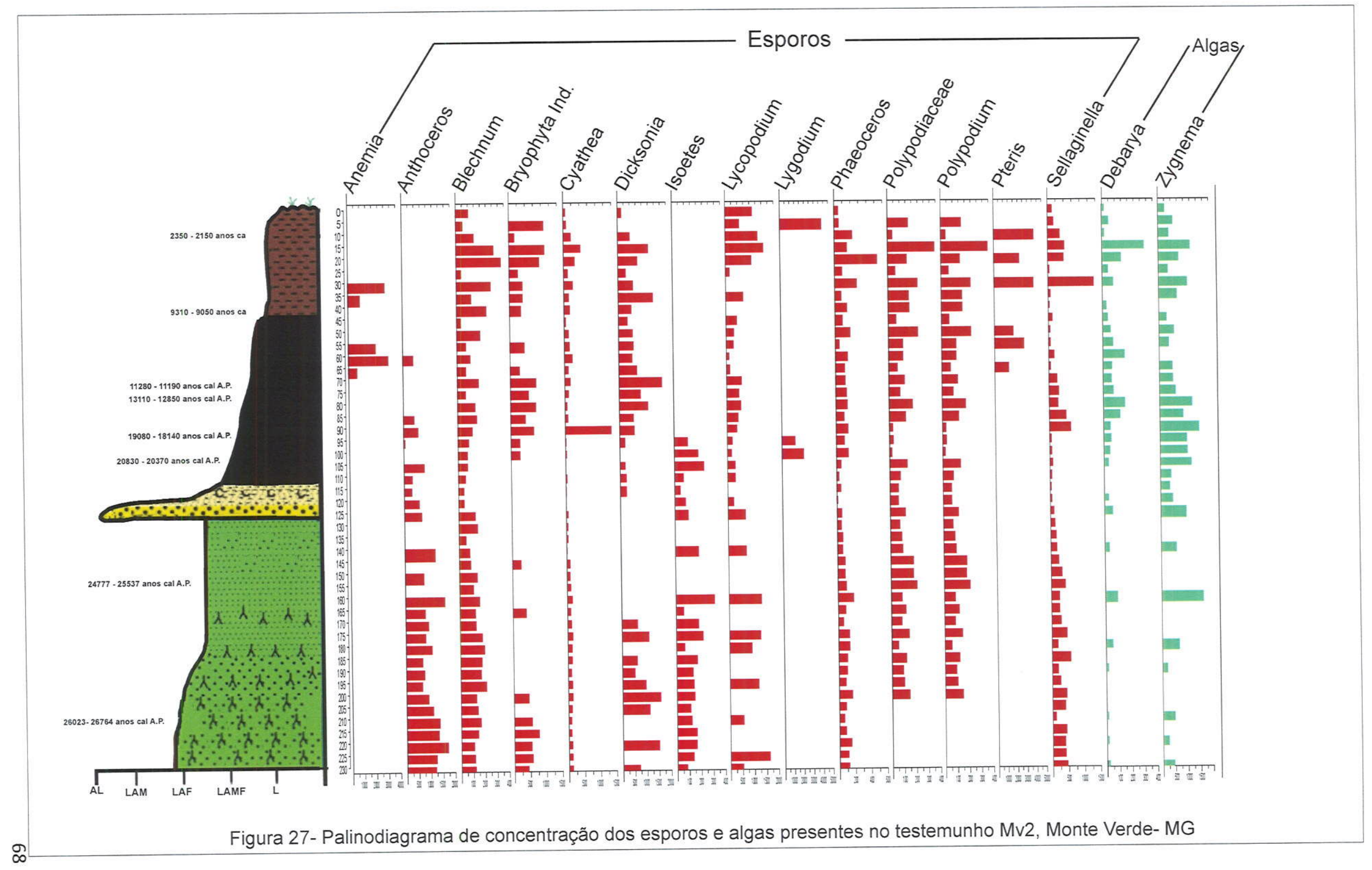




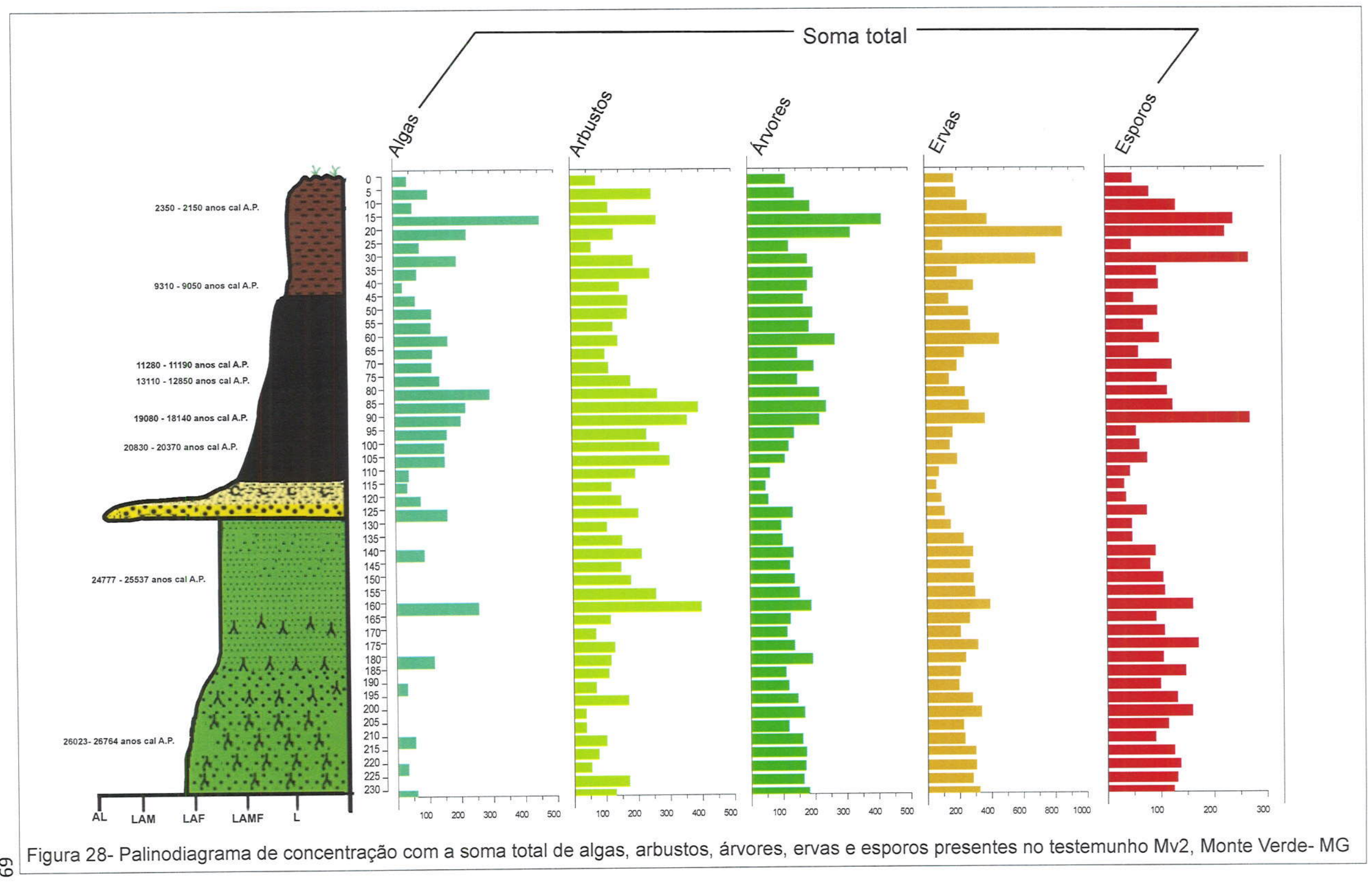




\subsection{Granulometria e mineralogia}

Os resultados de análise granulométrica dos testemunhos MV1 e MV2, incluindo distribuição em classes de 1 phi e estatísticas descritivas, encontram-se listados nas Tabelas 4 a 7 (Anexos VIII, IX, X e XI), respectivamente. Proporções em massa por classe e medidas estatísticas da distribuição foram lançados em gráficos de barras, em função da profundidade, para evidenciamento e interpretação das variações verticais. Resultados da análise quantitativa de minerais pesados na classe areia muito fina ( 3 a 4 phi) foram tabelados (Tabelas 8 e 9 - Anexos XII e XIII) e representados graficamente de maneira similar, de modo a permitir a interpretação integrada dos resultados de textura e mineralogia (Figuras 29 a 82 ).

\subsubsection{Testemunho MV1}

\section{a) Exame geral}

Os resultados granulométricos relativos ao testemunho MV1 indicam teores de pelíticos sempre superiores a $60 \%$ (Figura 29), com argila variável entre 24 e $52 \%$ (Figura 30). Maiores proporções das classes arenosas mais grossas (areia muito grossa, Figura 31; areia grossa, Figura 32; e areia média, Figura 33) são encontrados nos $40 \mathrm{~cm}$ superiores da coluna sedimentar, bem como nos intervalos de 90 a $95 \mathrm{~cm}, 120$ a $130 \mathrm{~cm}$ e 160 a $170 \mathrm{~cm}$. A classe areia média apresenta concentração relativamente elevada também no intervalo entre $190 \mathrm{e}$ $205 \mathrm{~cm}$. O teor de argila é menor nesses intervalos. Quando analisadas as medidas estatísticas de distribuição de freqüências da fração areia, os mesmos quatro intervalos caracterizam-se por valores de diâmetro médio ligeiramente mais grosso (Figura 36), desvio padrão mais elevado (Figura 37), assimetria menos negativa (Figura 38) e curtose mais baixa (Figura 39), o que indica perda de seleção dentro da fração (aumento na variabilidade de tamanho de grãos de areia), com deslocamento da moda para o lado dos grossos. Nota-se ainda tendência de aumento para cima na concentração das frações arenosas ao longo dos $85 \mathrm{~cm}$ superiores do testemunho, com queda no teor de argila, engrossamento do diâmetro médio, piora da seleção, aumento da assimetria e 
diminuição da curtose da fração areia. As frações areia fina e areia muito fina possuem a mesma tendência de variação (Figura 34 e 35).
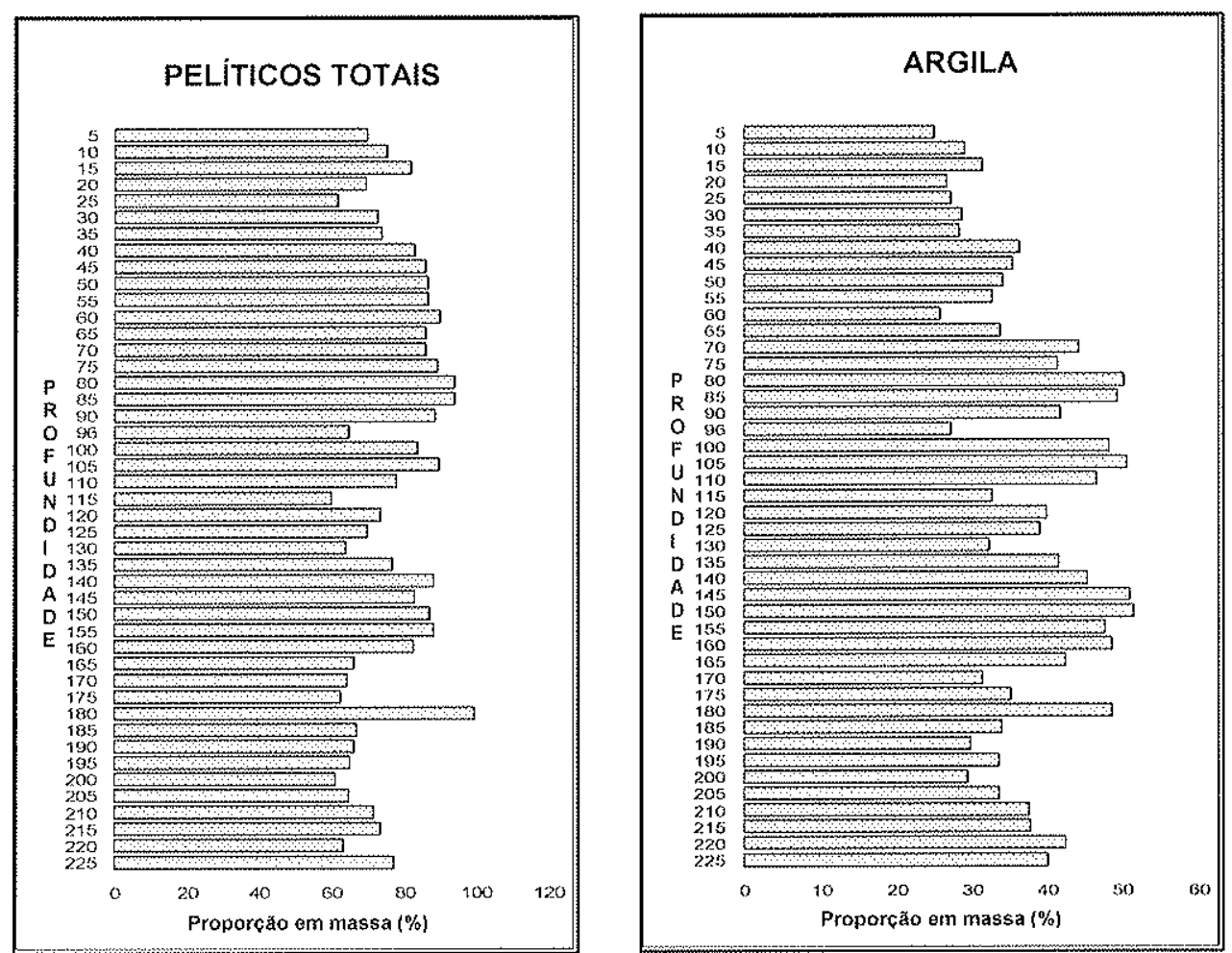

Figura 29- Variação de peliticos totais, ao longo do testemunho MV1.

Figura 30- Variação da fração argila, ao longo do testemunho MV1.
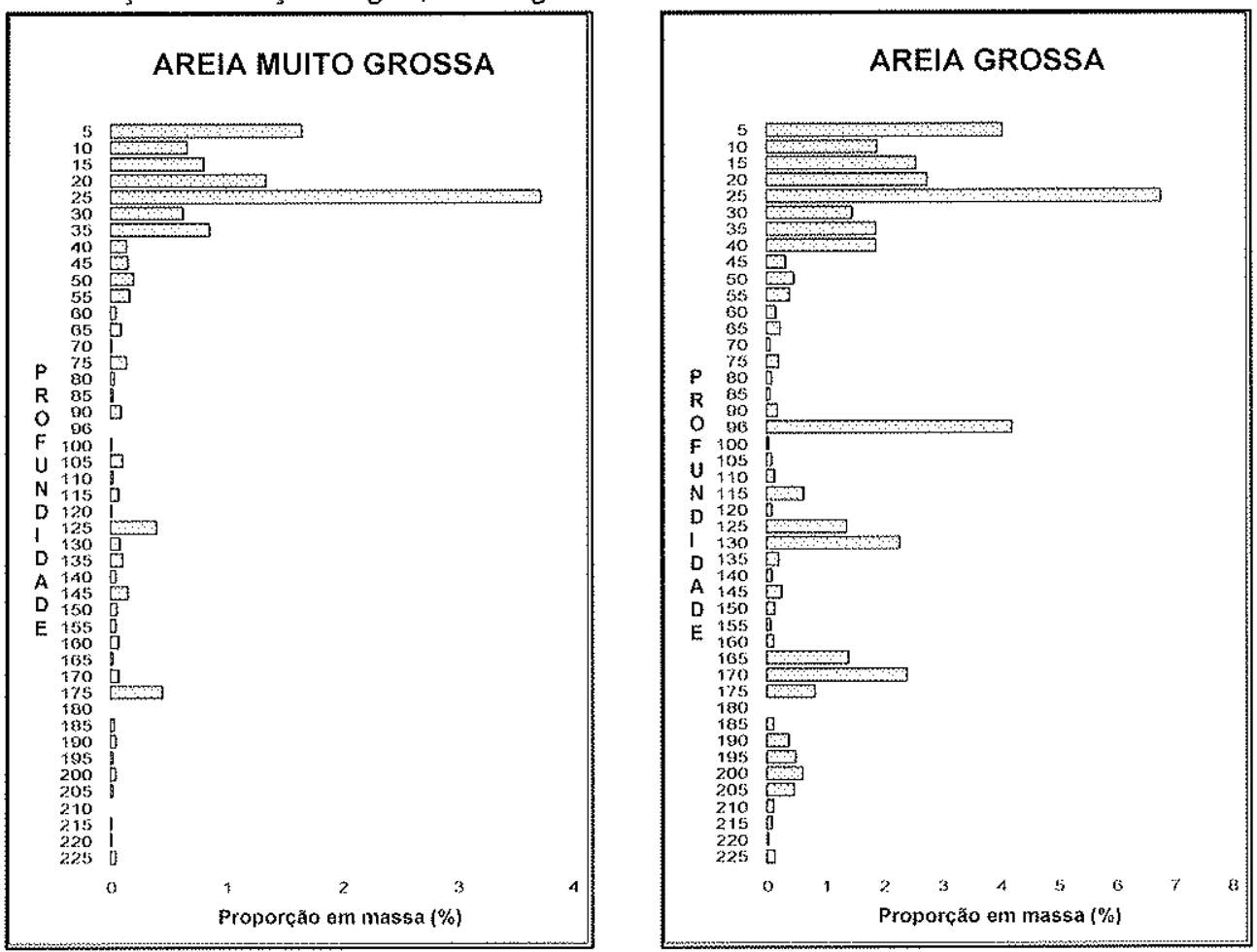

Figura 31- Variação da classe areia muito grossa, ao longo do testemunho MV1.

Figura 32- Variação da classe areia grossa, ao longo do testemunho MV1. 


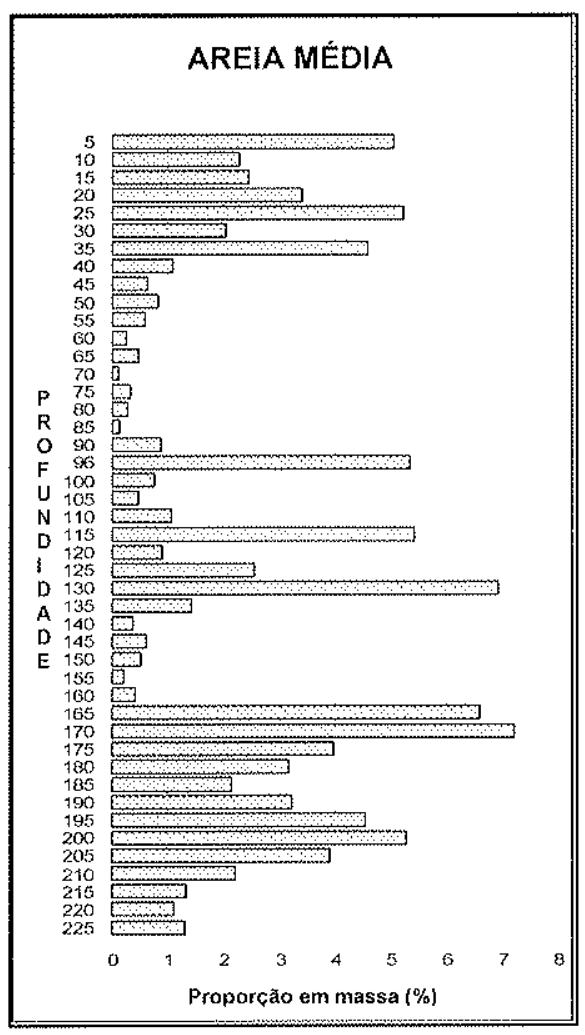

Figura 33- Variação da classe areia média, ao longo do testemunho MV1.
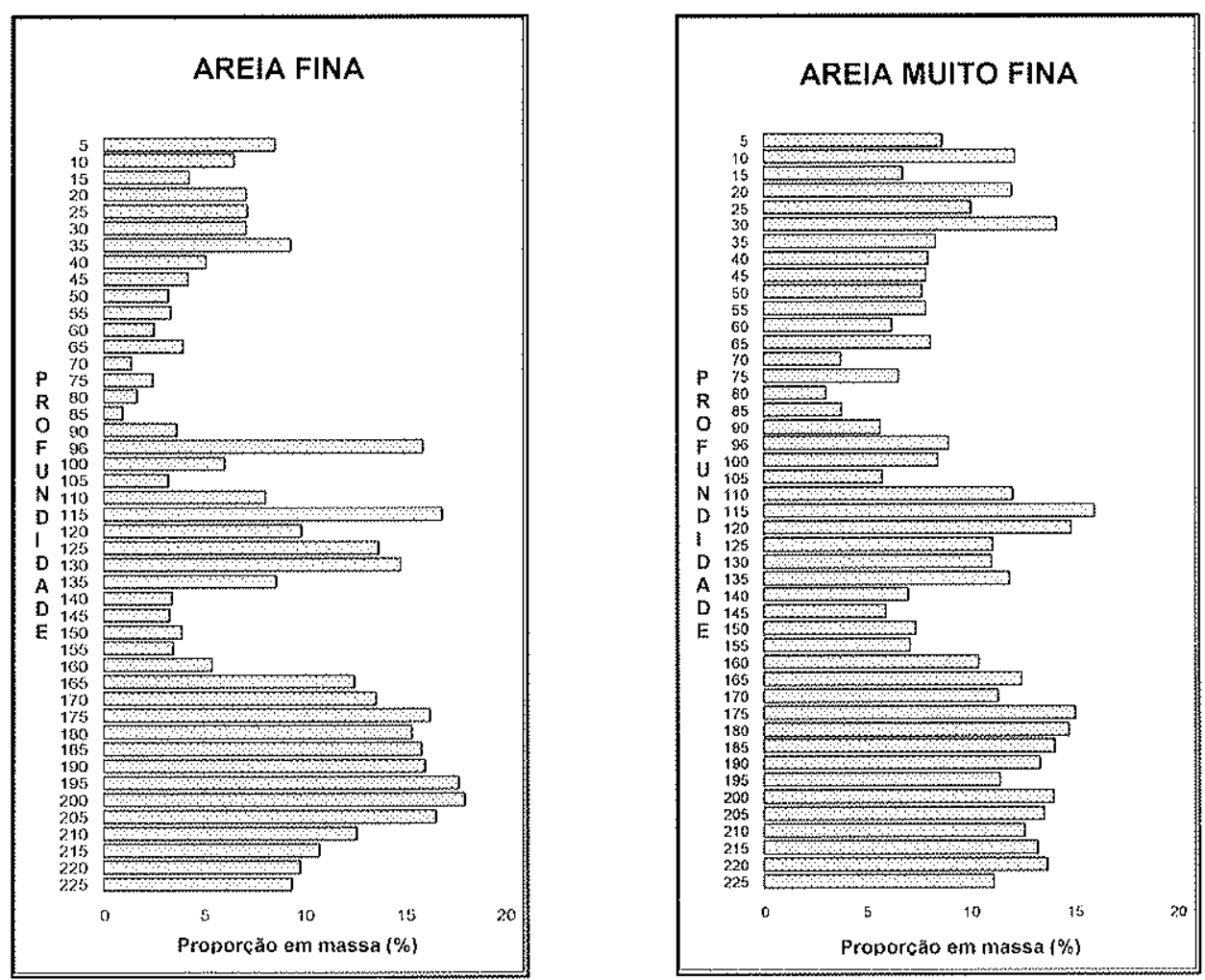

Figura 34- Variação da classe areia fina, ao longo do testemunho MV1.

Figura 35- Variação da classe areia muito fina, ao longo do testemunho MV1. 


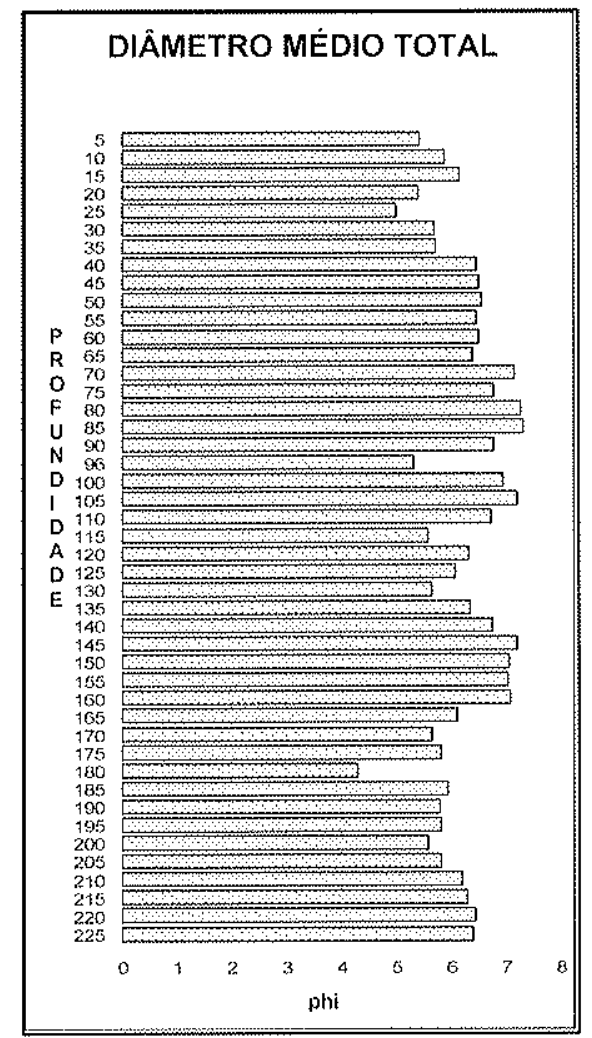

Figura 36. Variação do diâmetro médio da distribuição granulométrica total, ao longo do testemunho MV1.
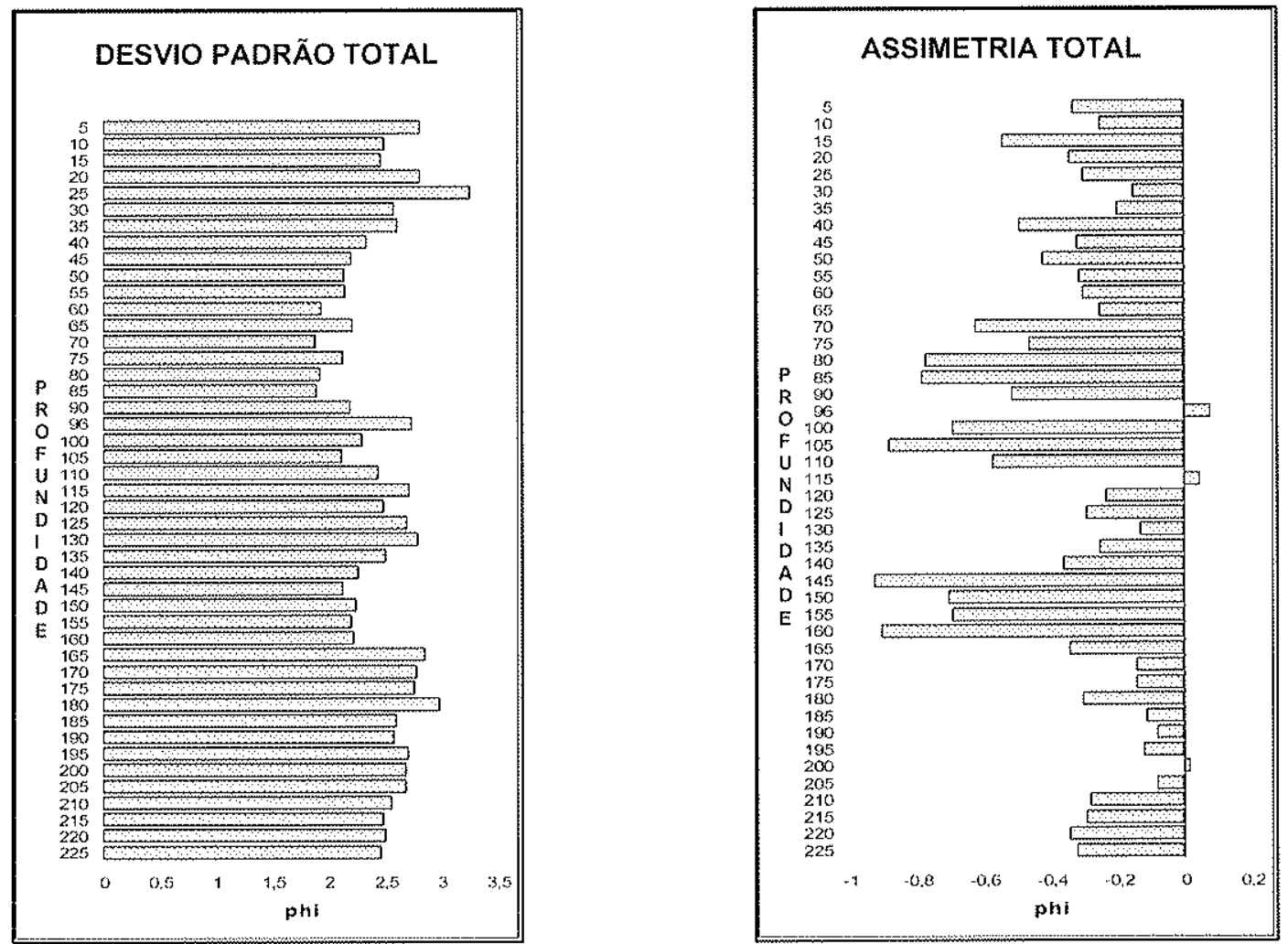

Figura 37- Variação do desvio padrão da distribuição granulométrica total, ao longo do testemunho MV1.

Figura 38- Variação da assimetria da distribuição granulométrica total, ao longo do testemunho MV1. 


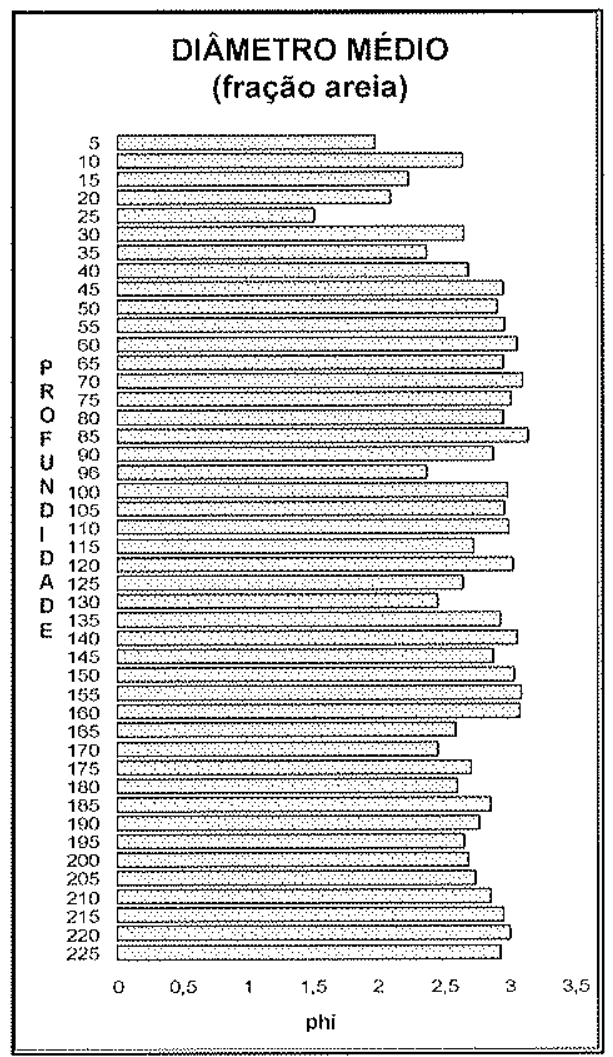

Figura 39- Variação do diâmetro médio da distribuição granulométrica na fração areia, ao longo do testemunho MV1.
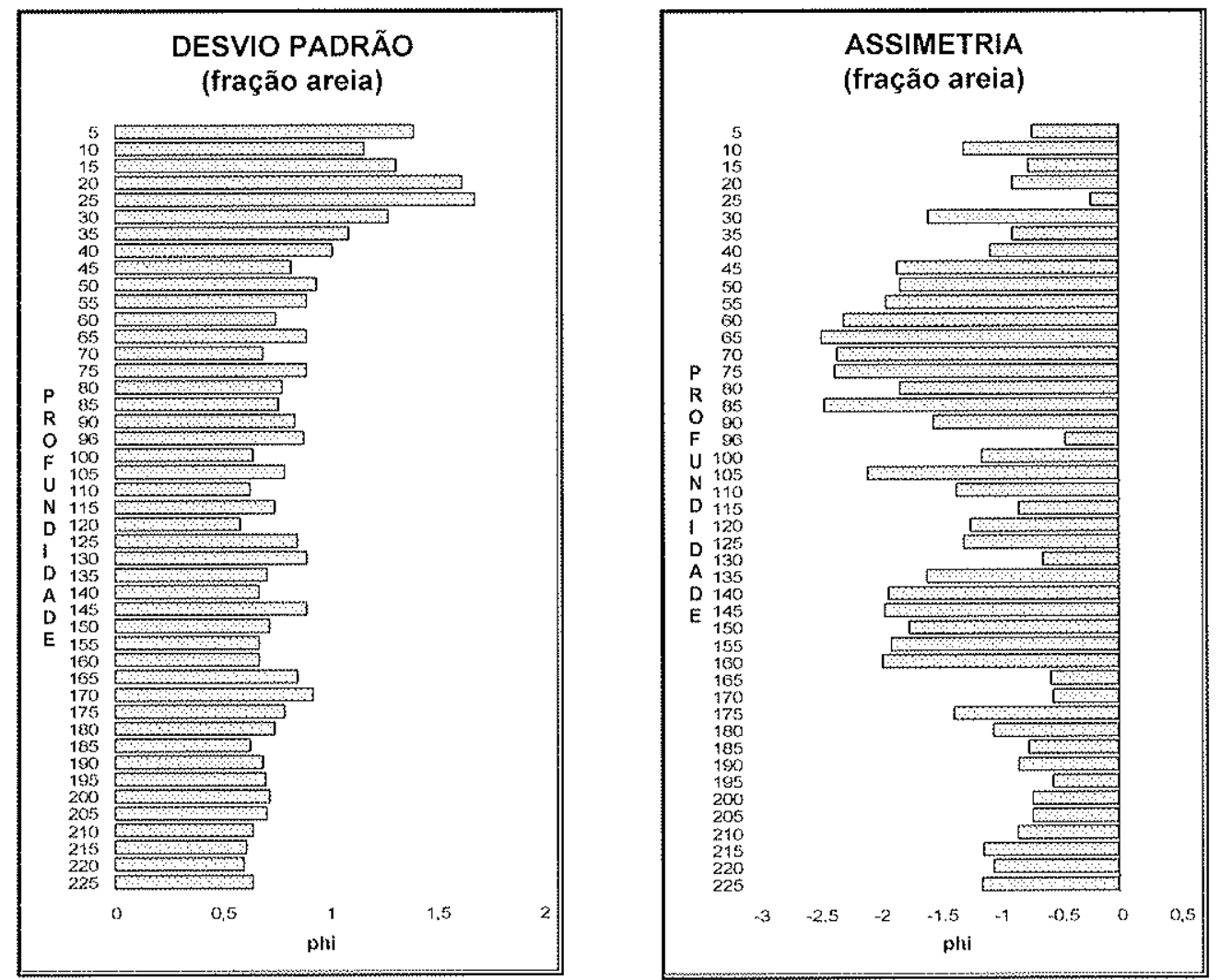

Figura 40- Variação do desvio padrão da distribuição granulométrica na fração areia, ao longo do testemunho MV1.

Figura 41- Variação da assimetria da distribuição granulométrica na fração areia, ao longo do testemunho MV1. 
Os minerais transparentes não micáceos perfazem entre 30 e $98 \%$ da fração pesada não magnética da classe areia muito fina, em valores de contagem. Dentre eles, apenas três foram encontrados em todas as amostras. Na ordem de abundância média decrescente, são eles: epídoto (54\%), zircão $(23 \%)$ e hornblenda $(11 \%)$. Alteritas $(6 \%)$ também estão sempre presentes. Outros minerais comuns, com ocorrência na maioria das amostras, e listados na ordem decrescente de concentração média, são: sillimanita $(1,4 \%)$, turmalina $(1,3 \%)$, titanita $(0,9 \%)$, rutilo $(0,6 \%)$ e anatásio $(<0,05 \%)$. Mais raramente, e sempre em concentração inferior a $4 \%$ dentre os componentes transparentes não micáceos, encontram-se granada, ferrossilita ("hiperstênio"), cianita, zoisita, apatita, perowskita, estaurolita, tremolita, diopsídio e augita. A presença da associação mineralógica sillimanita, cianita, estaurolita, típica de rocha metamórfica, permite sugerir que, apesar de localizada em meio a rochas granitoides da Fácies Cantareira (Figura 3), a área sedimentar quaternária estudada recebe influência, ainda que remota, dos gnaisses do Complexo Piracaia, atravessados pela porção superior da bacia de drenagem do Jaguari (Figura 3 ).

Minerais opacos ocorrem em todas as amostras, com concentração variável entre 1 e 67\% (Figura 42). Dentre os semi-opacos, agregados criptocristalinos de leucoxênio e material argilo-limonítico encontram-se na grande maioria das amostras, com concentrações de contagem de até 18 e 53\% da fração pesada não magnética, respectivamente (Figuras 43). Os agregados argilo-limoníticos claramente aumentam sua concentração nos $35 \mathrm{~cm}$ superiores da coluna (Figura 43), indício de que se formam por oxidação de minerais com ferro no topo do perfil pedogênico.

Os intervalos da coluna sedimentar assinalados como de aumento relativo na concentração de classes granulométricas mais grossas apresentam aumento também na proporção de opacos (Figura 42), de zircão (Figura 44) e dos índices mineralógicos relacionados com este último mineral (ZTR e ZE: Figuras 52 e 53), exceto no intervalo de profundidade de 120 a $130 \mathrm{~cm}$. Esta correlação direta de opacos, zircão e seus índices relacionados com as frações mais grossas sugere que estas variáveis mineralógicas possam ter significado hidráulico, isto é, em termos de competência do transporte sedimentar. 


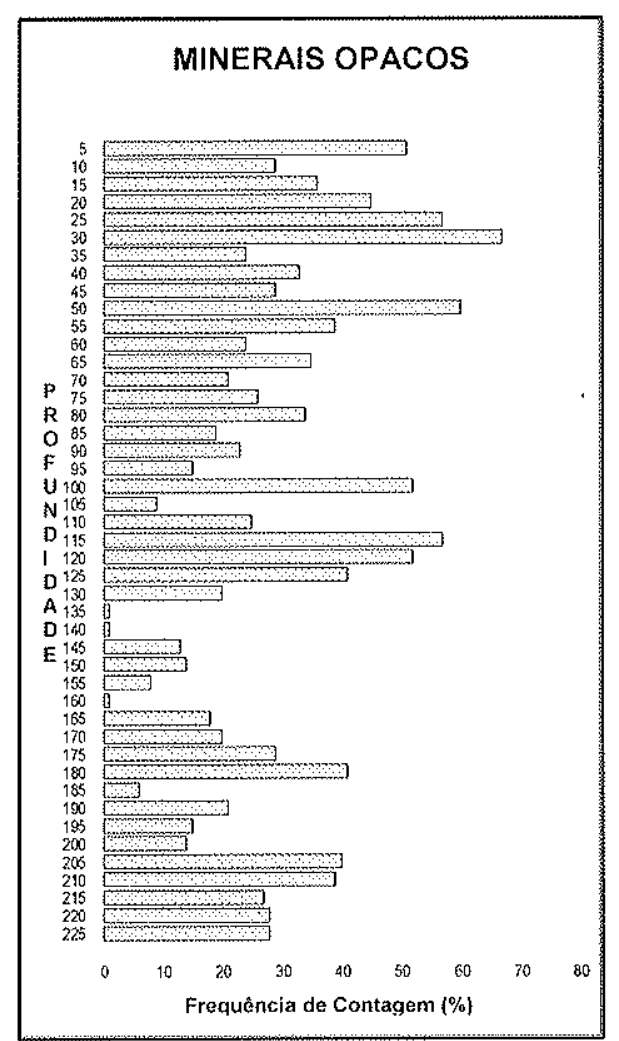

Figura 42. Variação da frequência de contagem de minerais opacos dentre pesados transparentes não micáceos da classe areia muito fina, ao longo do testemunho MV1.

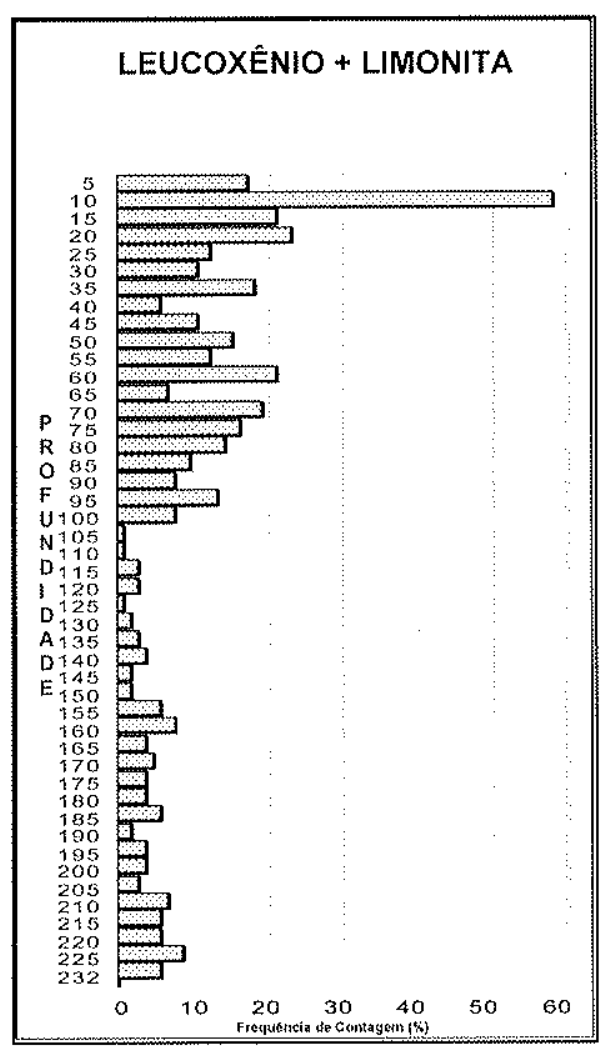

Figura 43 Variação da frequência de contagem de leucoxênio e limonita dentre pesados transparentes não micáceos da classe areia muito fina do testemunho MV1. 


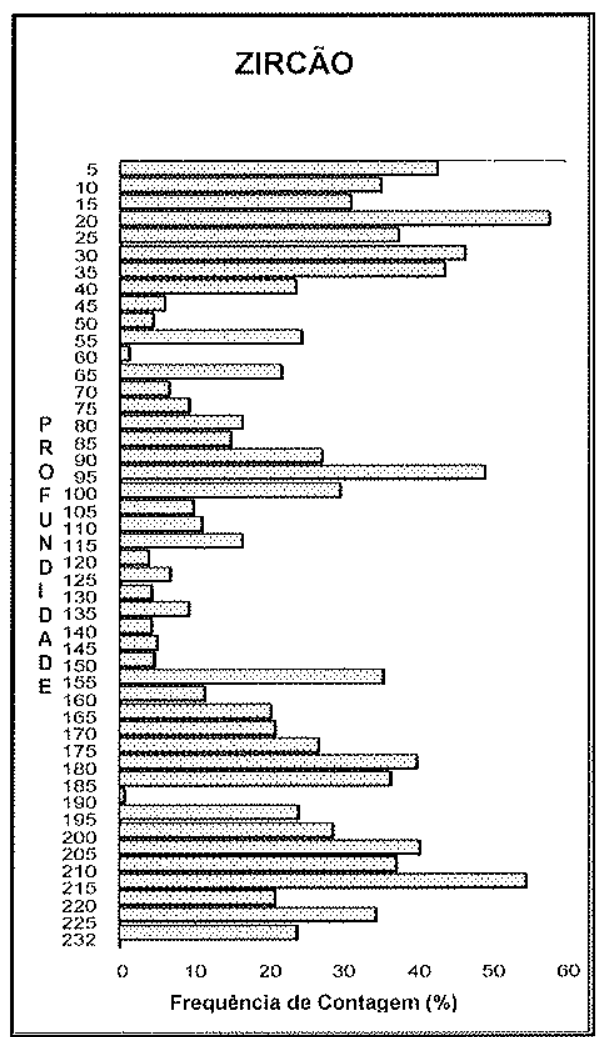

Figura 44- Variação da frequência de contagem de zircão dentre pesados transparentes não micáceos da classe areia muito fina, ao longo do testemunho MV1.
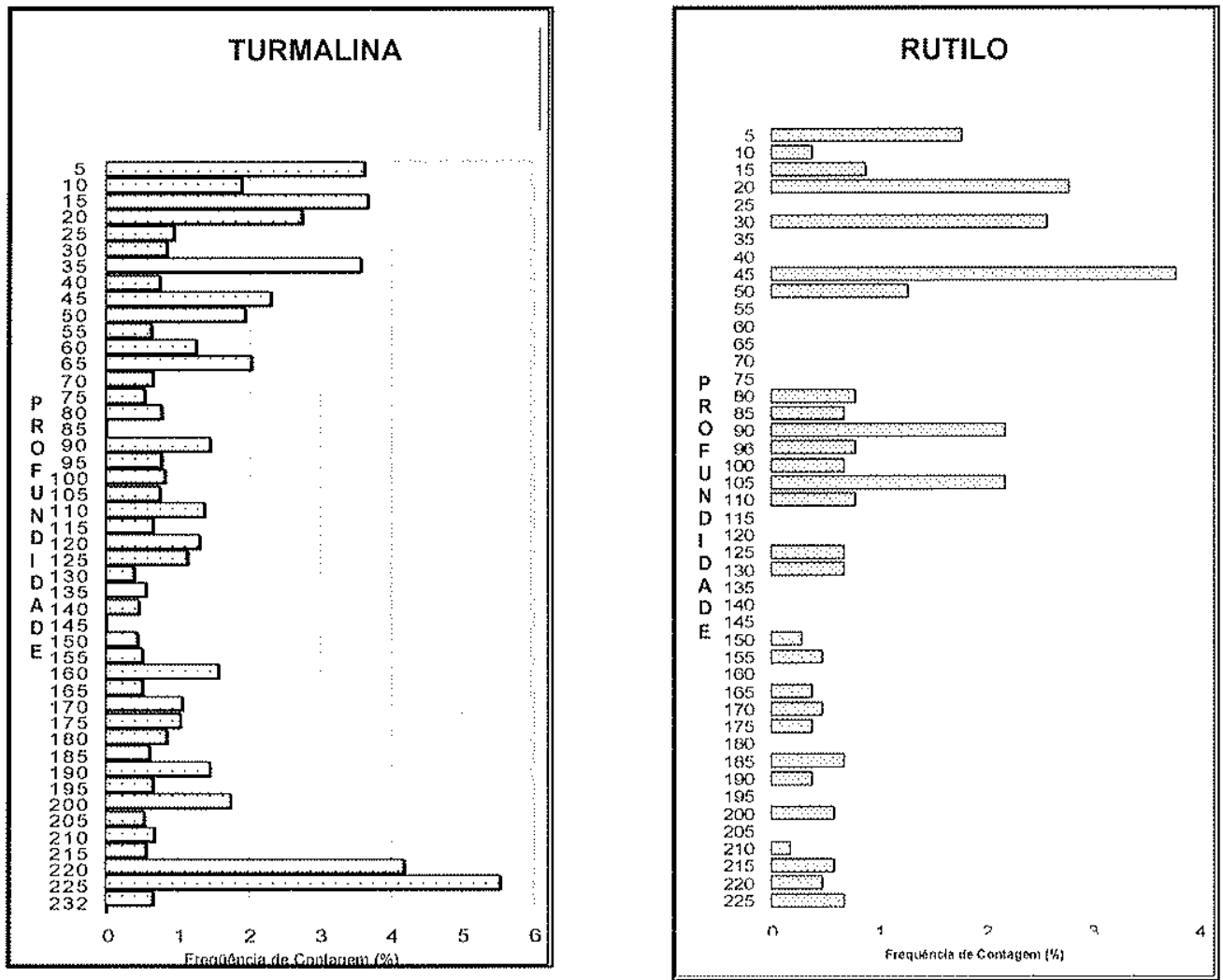

Figura 45- Variação da frequência de contagem de turmalina dentre pesados transparentes não micáceos da classe areia muito fina, ao longo do testemunho MV1.

Figura 46- Variação da frequência de contagem de rutilo dentre pesados transparentes não micáceos da classe areia muito fina, ao longo do testemunho MV1. 

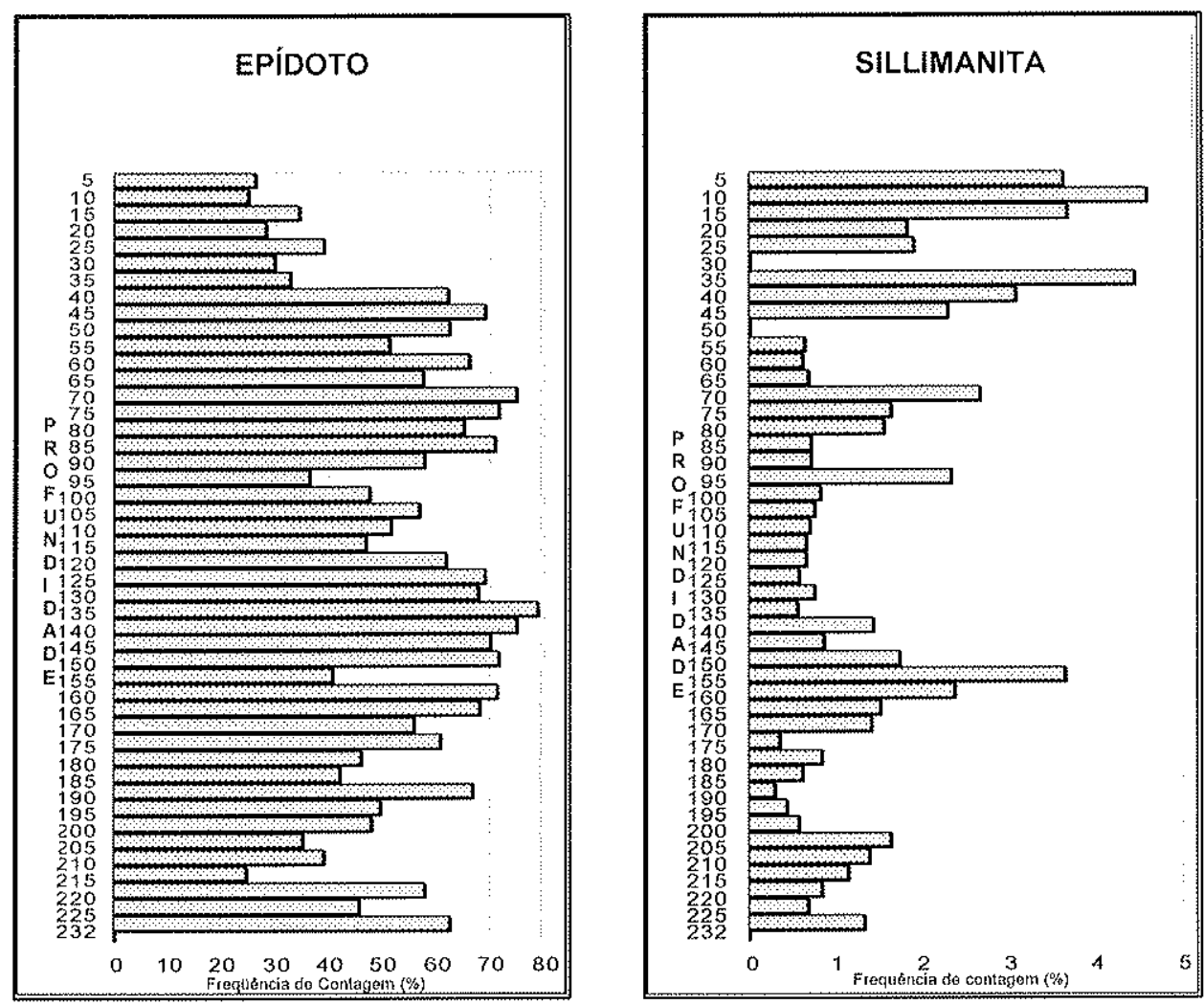

Figura 47- Variação da frequência de contagem de epidoto dentre pesados transparentes não micáceos da classe areia muito fina, ao longo do testemunho MV1.

Figura 48- Variação da frequência de contagem de sillimanita dentre pesados transparentes não micáceos da classe areia muito fina, ao longo do testemunho MV1.

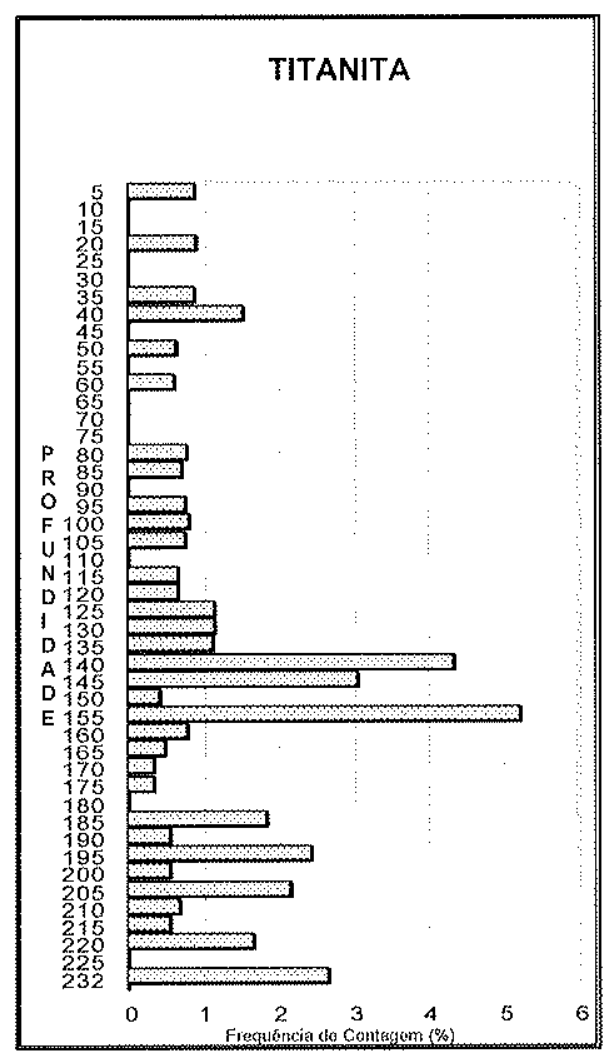

Figura 49- Variação da frequência de contagem de titanita dentre pesados transparentes não micáceos da classe areia muito fina, ao longo do testemunho MV1. 

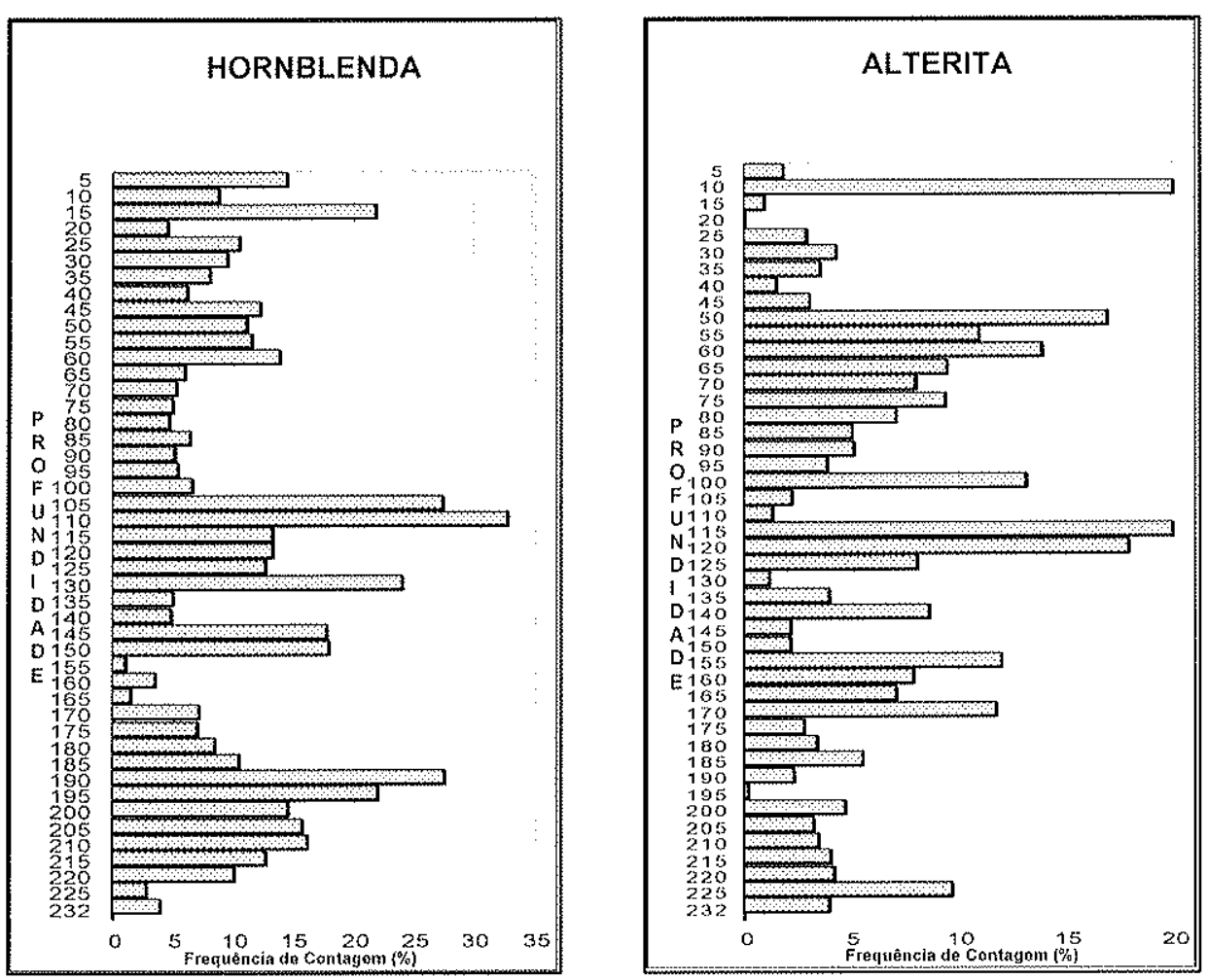

Figura 50. Variação da frequência de contagem de hornblenda dentre pesados transparentes não micáceos da classe areia muito fina do testemunho MV1.

Figura 51- Variação da frequência de contagem de alterita dentre pesados transparentes não micáceos da classe areia muito fina do testemunho MV1.
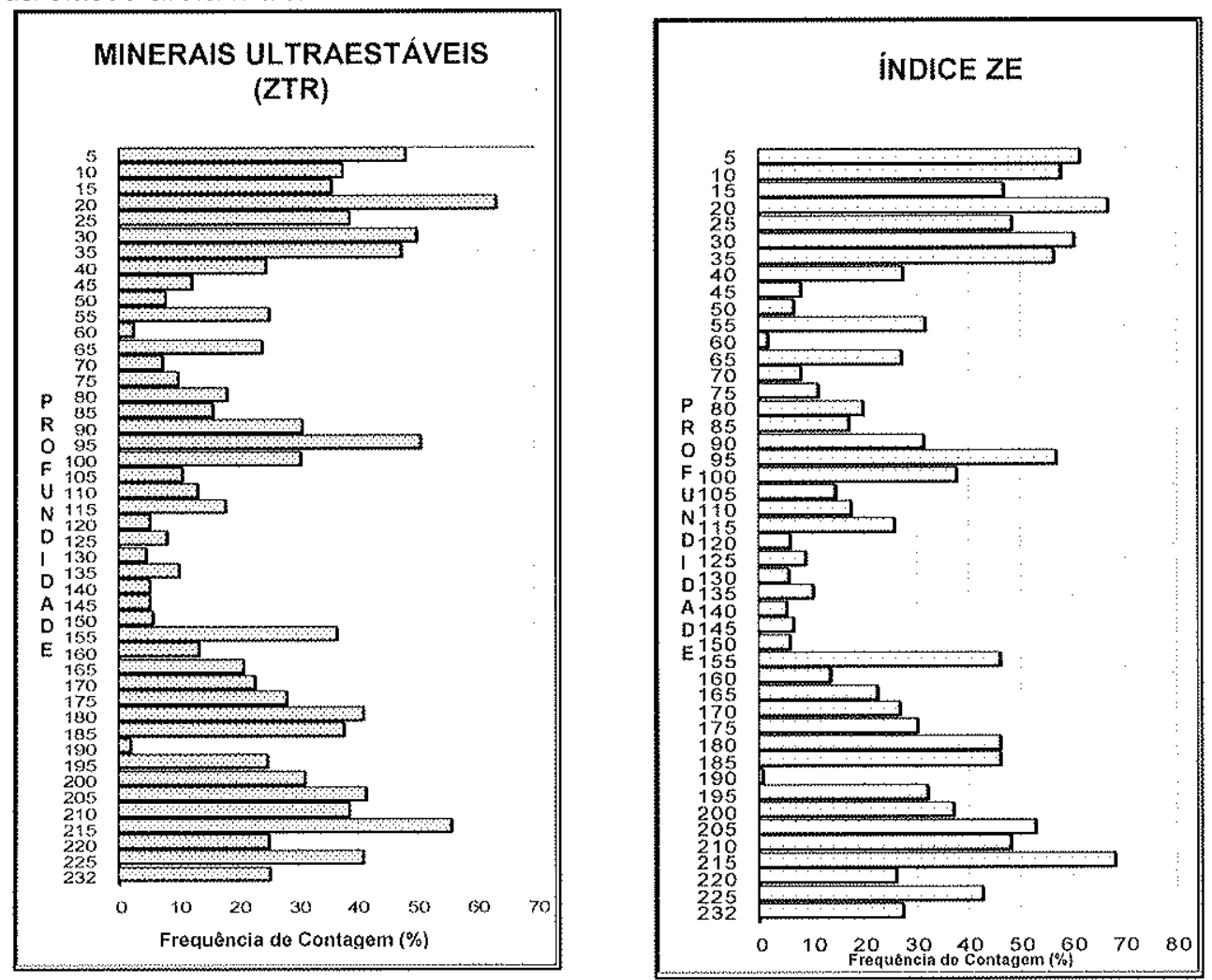

Figura 52-Variação da frequência de contagem de minerais ultraestáveis dentre pesados transparentes não micáceos (indice ZTR) da classe areia muito fina, ao longo do testemunho MV1. Figura 53- Variação do indice $Z E$, baseado nas frequências de contagem de zircão e epidoto na classe areia muito fina, ao longo do testemunho MV1. 
Nesses mesmos intervalos, nota-se também aumento do índice $\mathrm{SH}$, sillimanita/hornblenda (Figura 54), e, no intervalo de 160 a $170 \mathrm{~cm}$, do indice TH, turmalina/hornblenda (Figura 55). Sendo a hornblenda de densidade e hábito similar, porém de estabilidade química menor que as de sillimanita e turmalina, torna-se possível interpretar também um aumento de maturidade mineralógica do aporte sedimentar nestes intervalos.
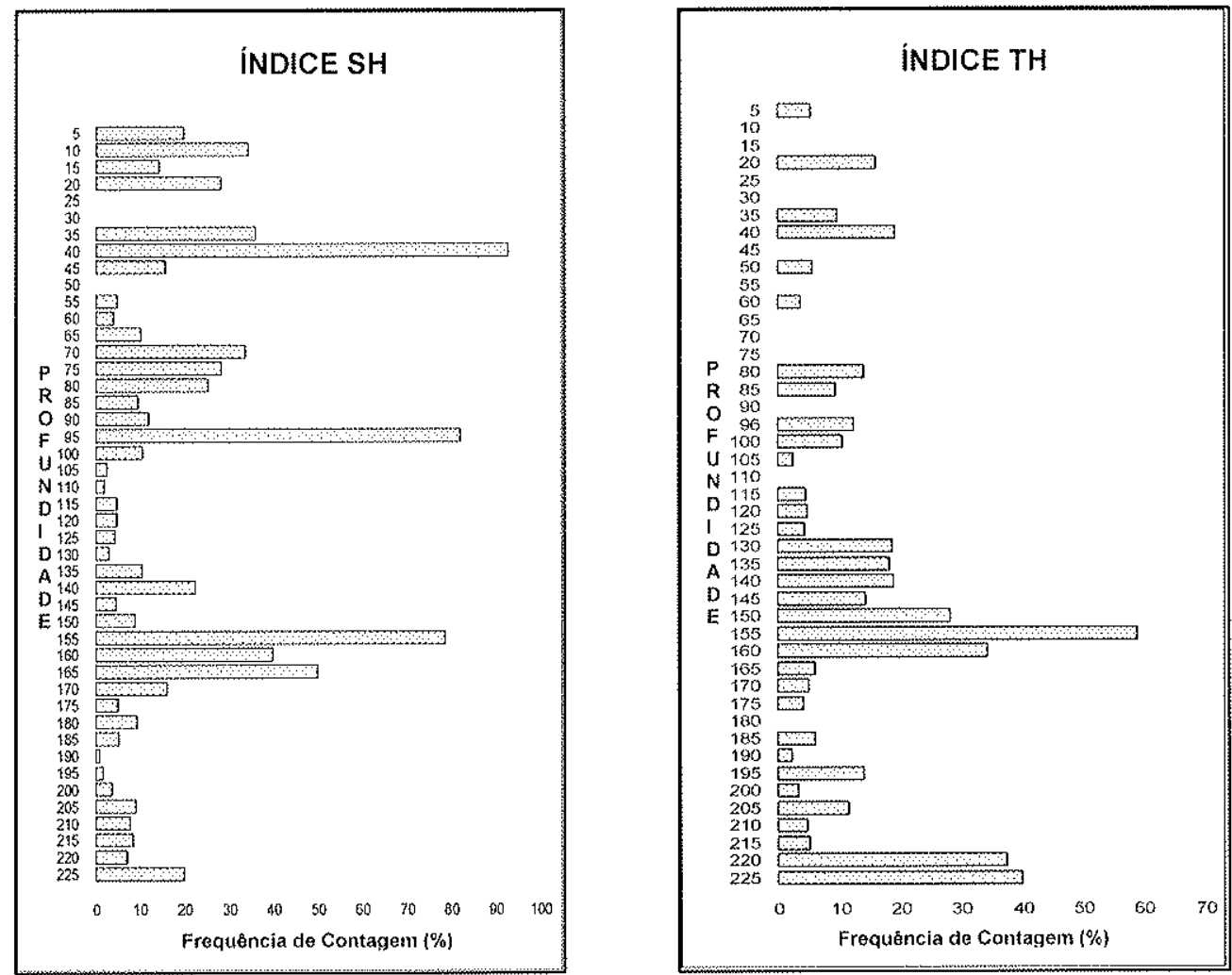

Figura 54- Variação do indice $\mathrm{SH}$, baseado nas frequências de contagem de sillimanita e hornblenda, na classe areia muito fina, ao longo do testemunho MV1.

Figura 55- Variação do indice $\mathrm{TH}$, baseado nas frequências de contagem de sillimanita e hornblenda, na classe areia muito fina, ao longo do testemunho MV1.

\section{b) Padrões de variação vertical}

A coluna sedimentar de MV1 pode ser dividida em dois trechos maiores quanto à variação vertical das medidas granulométricas da fração areia: de 232 a $110 \mathrm{~cm}$ e acima de $110 \mathrm{~cm}$. O trecho inferior não apresenta tendência geral clara e contínua na variação nas estatísticas, mas dentro dele podem ser reconhecidos dois sub-trechos com tendências melhor definidas: de 232 a $200 \mathrm{~cm}$ e de 200 a $175 \mathrm{~cm}$. O trecho superior apresenta tendência geral de variação, ainda que dentro dele também possam ser reconhecidos três sub-trechos com padrões de variação definidos: de 100 a $65 \mathrm{~cm}$, de 65 a $35 \mathrm{~cm}$, e de 35 a $5 \mathrm{~cm}$. Os trechos e 
sub-trechos com variação vertical regular subdividem-se em dois tipos de comportamento, de baixo para cima: o comportamento I, encontrado nos subtrechos de 200 a $175 \mathrm{~cm}$, de 100 a $65 \mathrm{~cm}$ e de 35 a $5 \mathrm{~cm}$, corresponde a um dos dois padrões de variação de McLaren (conforme item 4.3): melhora de grau de seleção, acompanhada de afinamento do diâmetro médio, com assimetria cada vez mais negativa. Mesmo padrão é observado, de maneira menos nítida, no intervalo de 175 a $100 \mathrm{~cm}$. O padrão de variação II, encontrado de baixo para cima na metade superior da coluna sedimentar e nos outros dois sub-trechos, 0 basal e o de 65 a $35 \mathrm{~cm}$, é exatamente oposto ao primeiro: piora de seleção, com engrossamento do tamanho médio e assimetria menos negativa.

Os padrões de McLaren, aplicados numa mesma paleogeografia, indicam seleção progressiva por transporte sedimentar (com afinamento ou com engrossamento), à medida que se afasta da área fonte. Desse modo, podem ser entendidos como indices de distalidade do sítio deposicional em relação a sua fonte sedimentar. Adaptado para a variação no registro vertical, ele sugere seleção mecânica (aerodinâmica ou hidráulica) crescente no tempo, seja por retrabalhamento sedimentar sucessivo, seja por redução gradual da influência da área fonte. No contexto sedimentar de MV1, que é o planície de inundação de rio de pequeno porte (canal com poucos metros de largura e menos de $1 \mathrm{~m}$ de lâmina de água em média), encaixado em alveólo de relevo serrano, o registro do padrão de McLaren em certos trechos da sucessão vertical permite diferentes interpretações de variações ao longo do tempo, tais como: adensamento ou fechamento da cobertura florestal na área de captação da drenagem, com intensificação da filtragem de sedimentos; redução da energia da drenagem, devido a diminuição da precipitação; migração do canal fluvial, afastando-se do ponto estudado e/ou passando a retrabalhar os sedimentos de sua própria planície de inundação. Estas seriam hipóteses aplicáveis ao padrão I encontrado em MV1. O padrão II, por ser inverso, daria indicações opostas a estas.

Um bom modo de testar se os dois padrões de variação encontrados estão de fato relacionados a controle hidráulico, como inicialmente admitido, é comparar o comportamento, ao longo da coluna, de minerais mais densos versus minerais menos densos. Se de fato este controle hidráulico existir, espera-se aumento ascendente de minerais menos densos, em detrimento dos mais densos, no caso 
I (padrão de McLaren), e o inverso, no caso II (McLaren invertido). As principais tendências regulares de variação de baixo para cima observadas dentre os minerais pesados nos trechos com padrão I, e que tiveram comportamento oposto em trechos com padrão II, são: redução nas concentrações de zircão e índices ZTR e ZE, e aumento de epídoto e indice TZ. Ressalte-se ainda que na metade superior do testemunho MV1, trecho com padrão II, existe tendência para cima de aumento do opacos. Considerando que zircão e opacos são justamente os componentes abundantes de maior densidade na assembleia mineralógica de pesados e que TZ é índice de seleção hidráulica, torna-se fortalecida a ideia de um provável controle hidrodinâmico a determinar a variação sedimentológica ao longo de MV1.

Em um dos sub-trechos com o comportamento I (100 a $65 \mathrm{~cm})$, nota-se também aumento para cima dos índices $\mathrm{SH}$ e $\mathrm{TH}$, o que permite interpretar que, neste intervalo, a suposta seleção hidráulica teria sido acompanhada de elevação da maturidade química, provavelmente por eliminação do componente mineralógico mais instável (hornblenda) durante o sucessivo retrabalhamento, que nesse caso teria presumivelmente incluído exposição aos agentes intempéricos. Analogamente, no intervalo basal (232 a $200 \mathrm{~cm})$, o comportamento II é acompanhado de redução dos índices $\mathrm{SH}$ e $\mathrm{TH}$, ou seja, de decréscimo de maturidade química.

Em suma, a variação sedimentológica vertical nos sub-trechos de 200 a $175 \mathrm{~cm}$, de 110 a $65 \mathrm{~cm}$ e de 35 a $5 \mathrm{~cm}$ aponta para aumento no tempo de distalidade, com redução da influência da fonte, enquanto a variação observada ao longo da metade superior como todo e nos sub-trechos de 232 a $200 \mathrm{~cm}$ e de 65 a $35 \mathrm{~cm}$ permite interpretar proximalidade crescente, isto é, aumento da influência da fonte. O sub-trecho de 175 a $115 \mathrm{~cm}$ resulta aparentemente de condições sedimentares mais homogêneas ao longo do tempo. 


\subsubsection{Testemunho MV2}

\section{a) Exame geral}

Os resultados granulométricos relativos ao testemunho MV2 indicam teores de pelíticos superiores a $54 \%$, alcançando até $94 \%$ (Figura 56), com argila variável entre 13 e $54 \%$ (Figura 57 ).

A coluna sedimentar apresenta clara compartimentação em duas metades, no que se refere tanto à relação areia/argila como à mineralogia. Essa divisão já fora notada, com base na granulação, durante a descrição preliminar de fácies, logo após a abertura do testemunho (contraste entre as fácies 1 a 4 e as fácies 5 e 6).
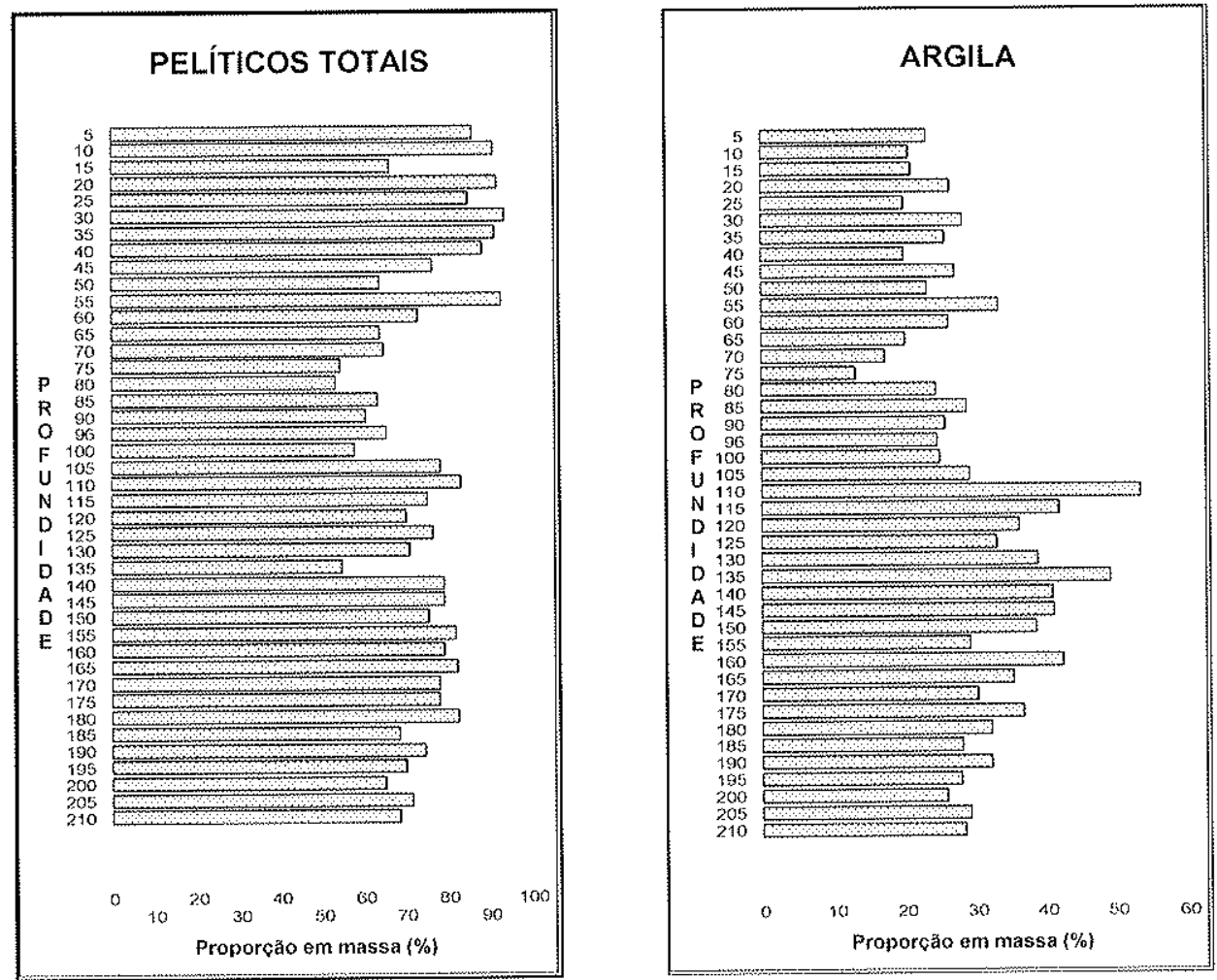

Figura 56- Variação de pelíticos totais, ao longo do testemunho MV2.

Figura 57- Variação da fração argila, ao longo do testemunho MV2.

Os principais trechos da coluna sedimentar com maior concentração das classes areia muito grossa (Figura 58), areia grossa (Figura 59) e areia média (Figura 60) ocorrem nos intervalos de profundidade de 10 a $15 \mathrm{~cm}$ e de 170 a 210 $\mathrm{cm}$. Aumento subordinado destas frações, principalmente areia média, encontrase ainda entre 40 e $105 \mathrm{~cm}$. A concentração destas classes é em média maior na metade inferior do testemunho, ao longo da qual apresenta tendência geral para 
decréscimo de baixo para cima. A fração argila, inversamente, aumenta de concentração para cima, ao longo da metade inferior, com pico máximo em 110 $\mathrm{cm}$.
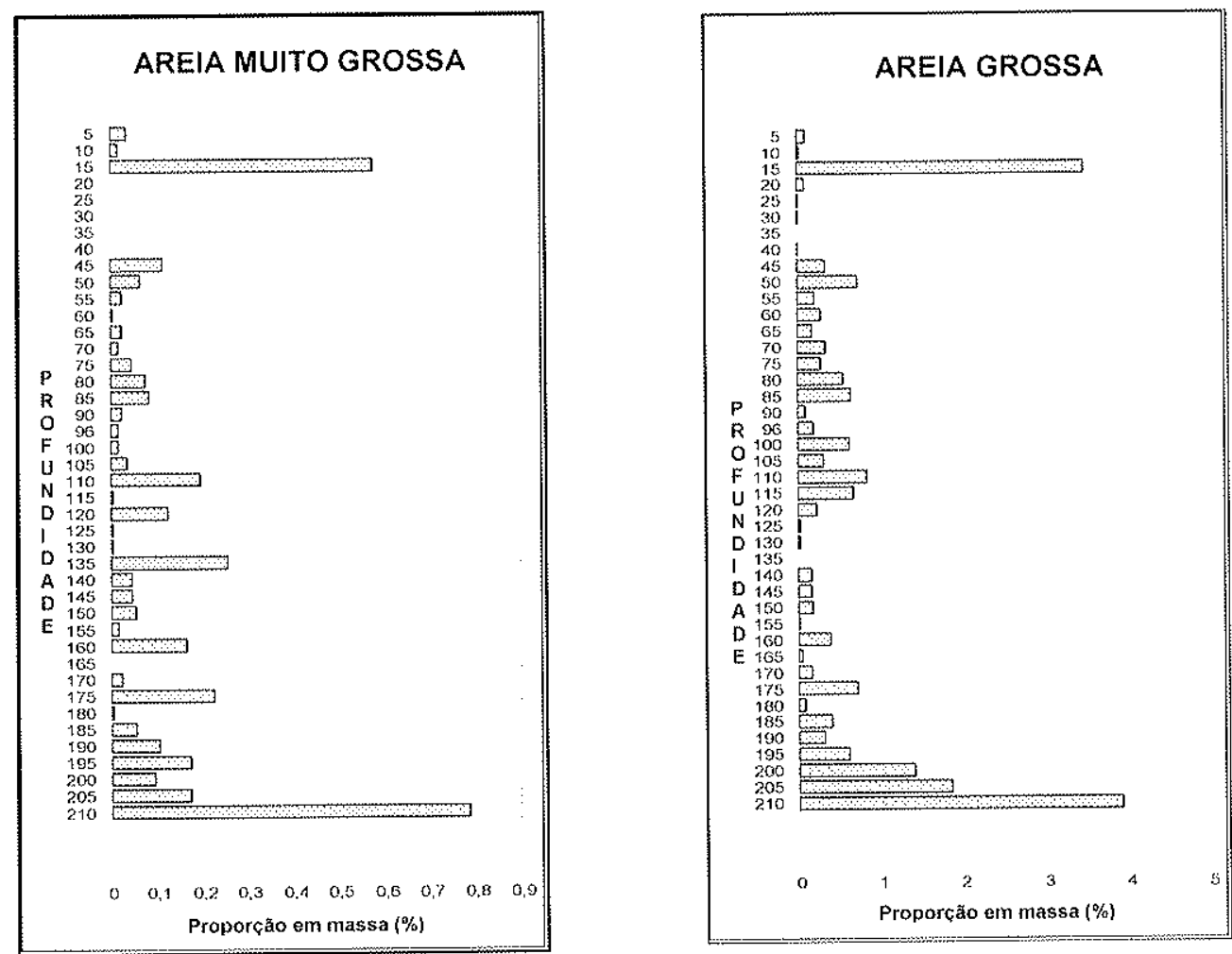

Figura 58- Variação da classe areia muito grossa, ao longo do testemunho MV2.

Figura 59- Variação da classe areia grossa, ao longo do testemunho MV2.

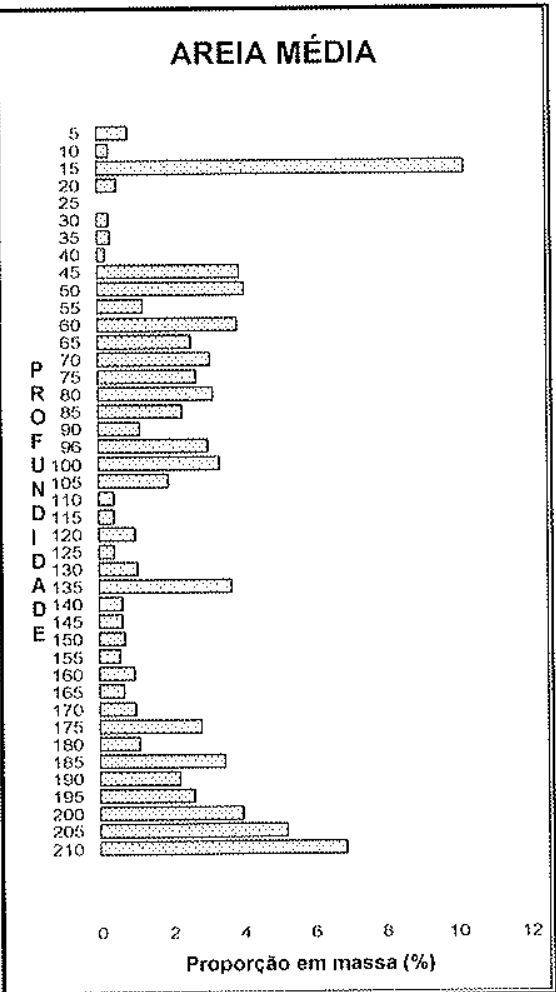

Figura 60- Variação da classe areia média, ao longo do testemunho MV2. 

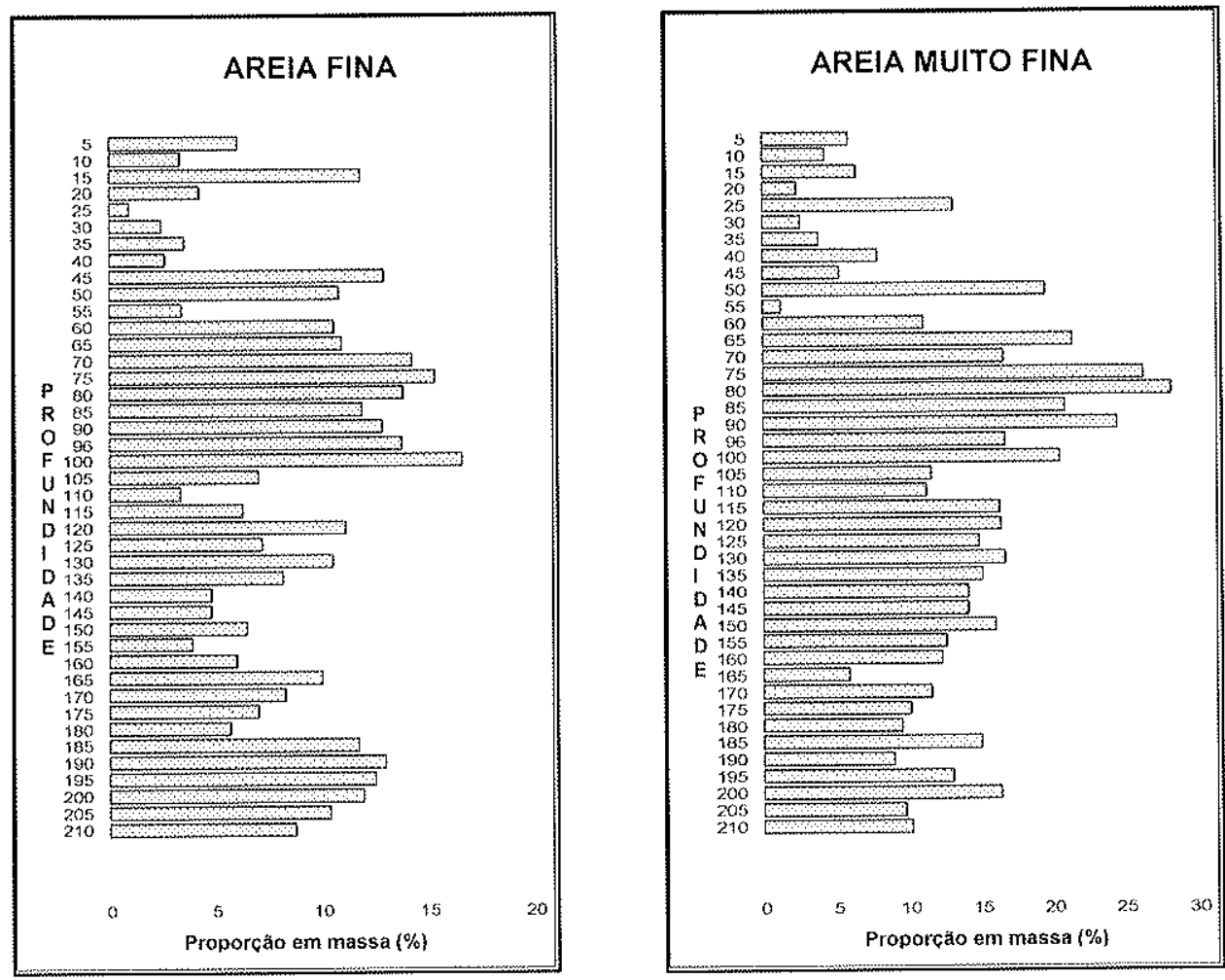

Figura 61- Variação da classe areia fina, ao longo do testemunho MV2.

Figura 62- Variação da classe areia muito fina, ao longo do testemunho MV2.

A exemplo do observado em MV1, as estatísticas de distribuição de freqüências da fração areia, nos intervalos com maiores concentrações das frações arenosas mais grossas, caracterizam-se por valores de diâmetro médio (Figura 63) ligeiramente mais grosso, desvio padrão mais elevado (Figura 64) assimetria menos negativa (Figura 65) e curtose mais baixa, o que indica perda de seleção dentro da fração com deslocamento da moda para o lado dos grossos. Assim, a metade inferior da coluna sedimentar, em que existe diminuição destas fraçöes mais grossas de baixo para cima, apresenta tendência ascendente para afinamento do diâmetro médio, melhora do grau de seleção e assimetria mais negativa (padrão de McLaren). 


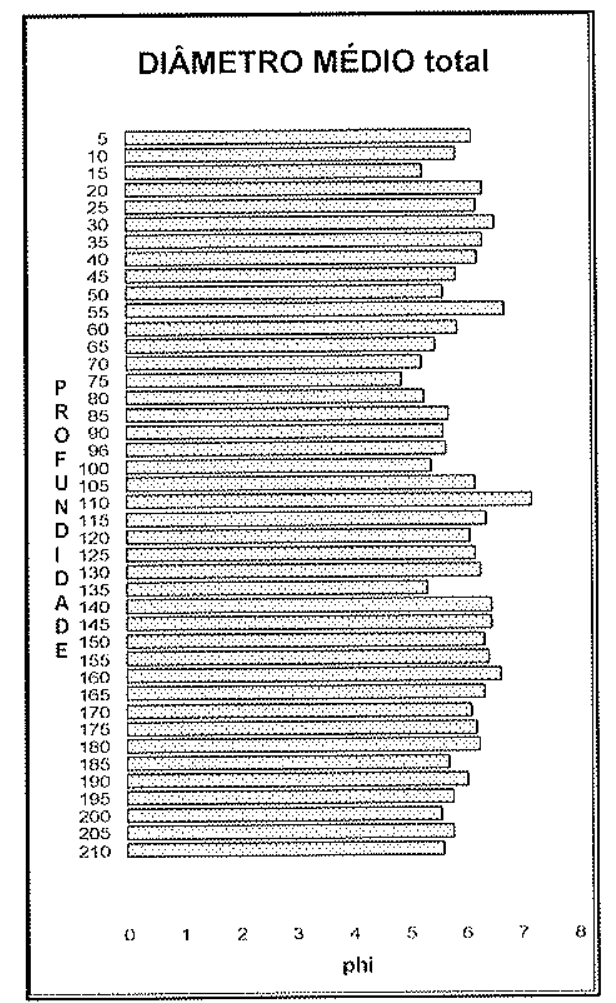

Figura 63- Variação do diâmetro médio da distribuição granulométrica total, ao longo do testemunho MV2.
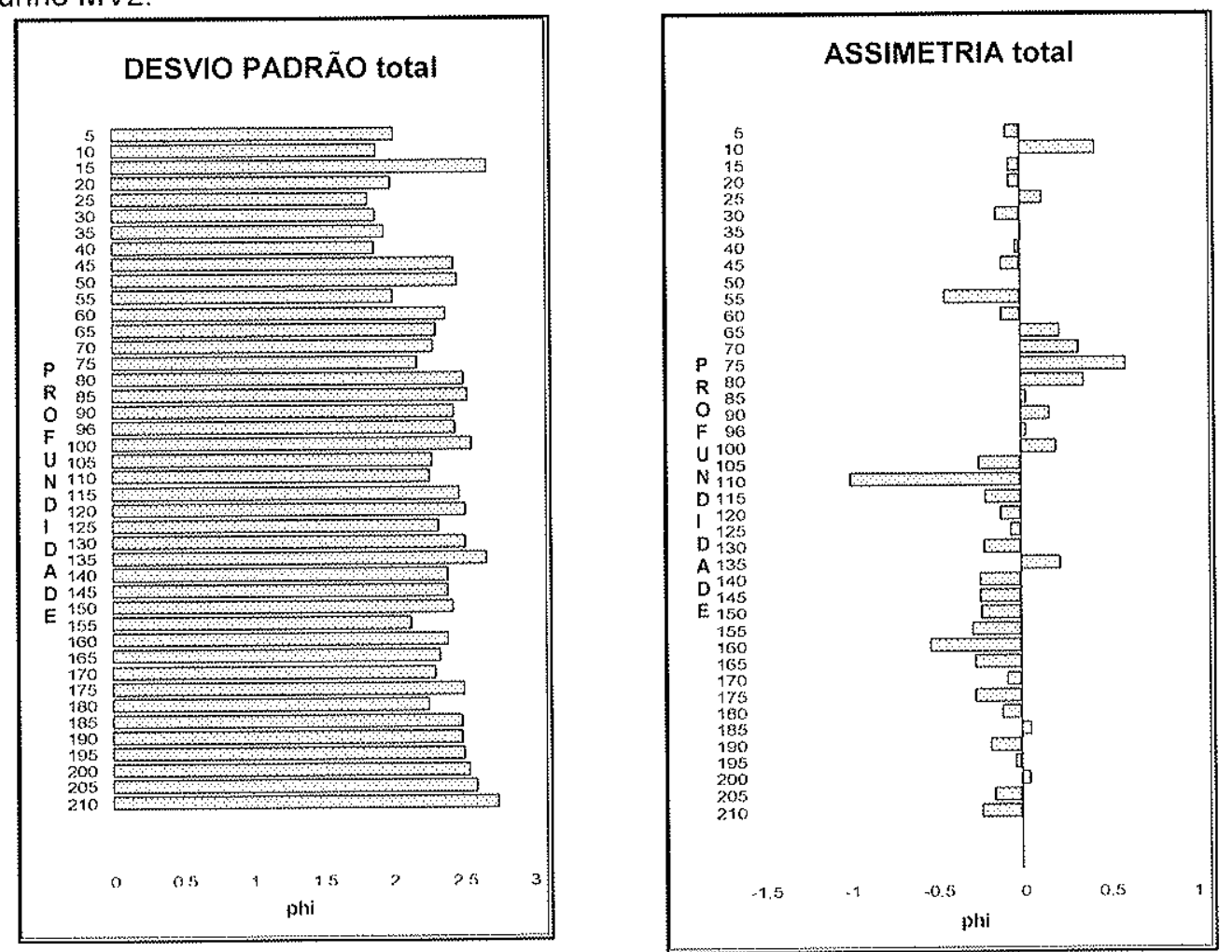

Figura 64- Variação do desvio padrão da distribuição granulométrica total, ao longo do testemunho MV2.

Figura 65- Variação da assimetria da distribuição granulométrica total, ao longo do testemunho MV2. 


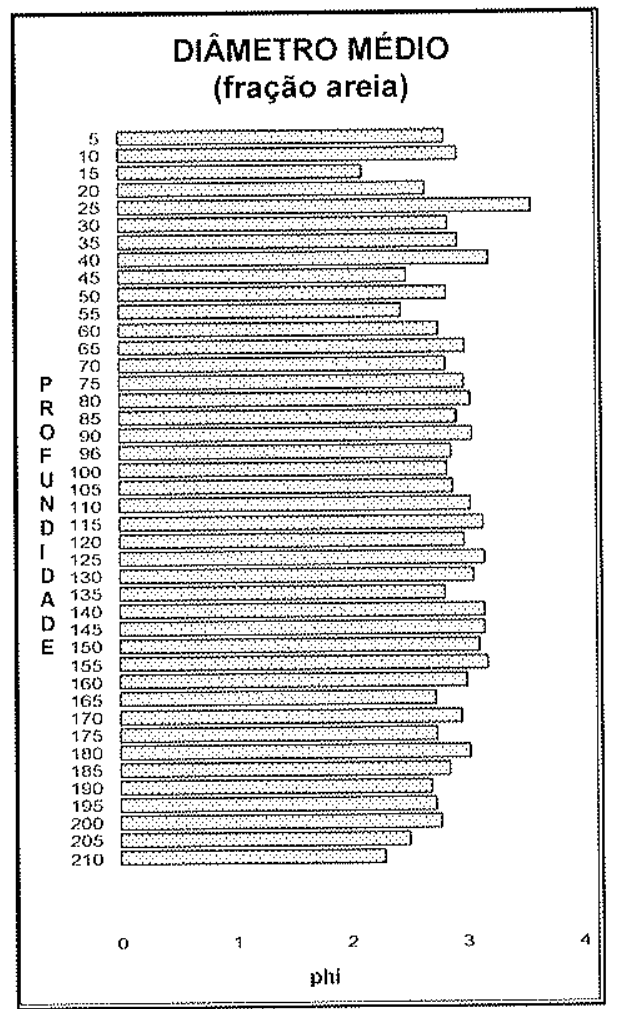

Figura 66- Variação do diâmetro médio da distribuição granulométrica na fração areia, ao longo do testemunho MV2.
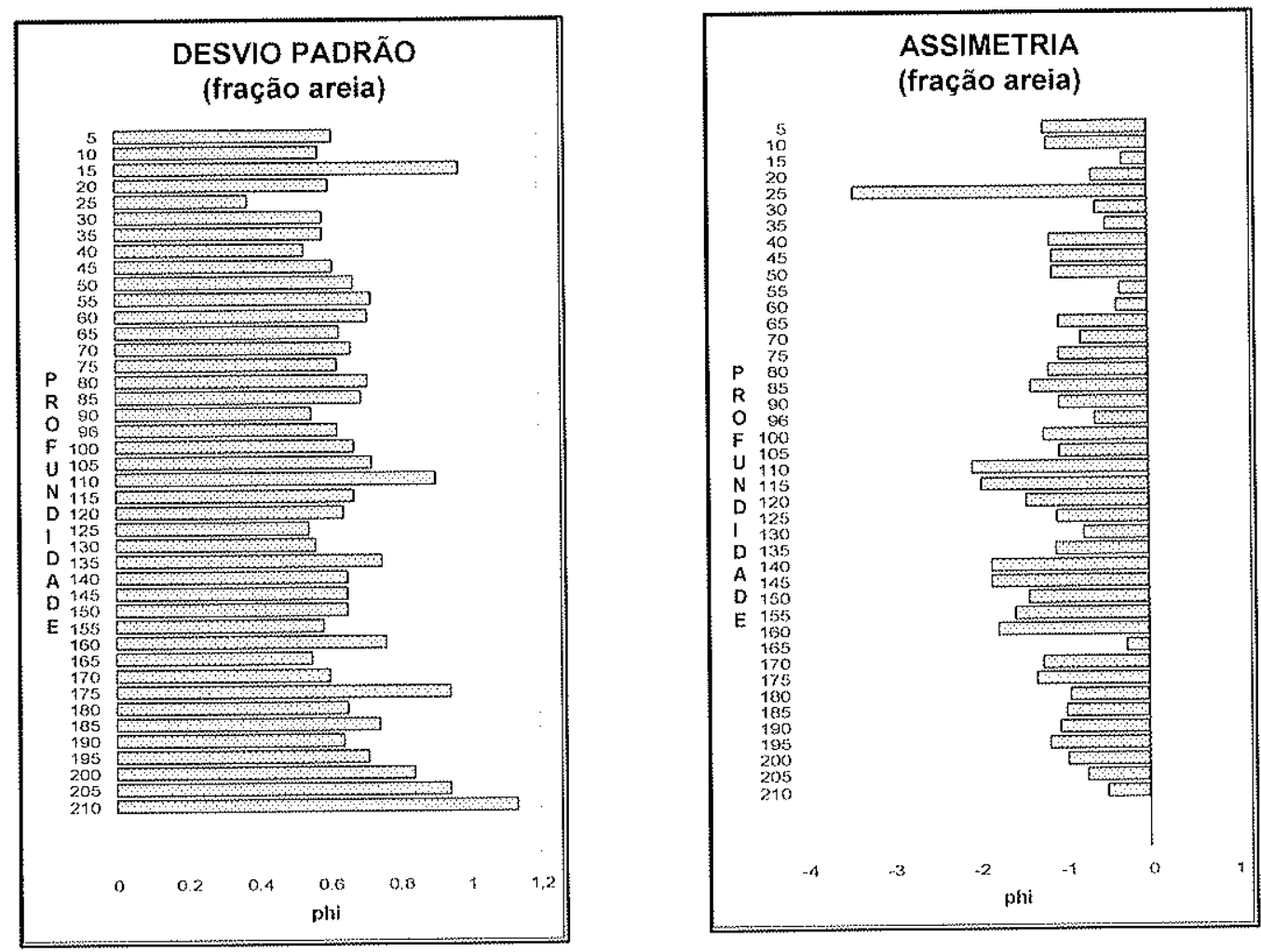

Figura 67- Variação do desvio padrão da distribuição granulométrica na fração areia, ao longo do testemunho MV2.

Figura 68- Variação da assimetria da distribuição granulométrica na fração areia, ao longo do testemunho MV2. 
Os minerais transparentes não micáceos perfazem entre 20 e $98 \%$ da fração pesada não magnética da classe areia muito fina (Figura 62). Dentre eles, apenas zircão e epídoto (Figuras 70 e 71) foram encontrados em todas as amostras, o primeiro com abundância média (77\%) muito maior de que o segundo $(12 \%)$.

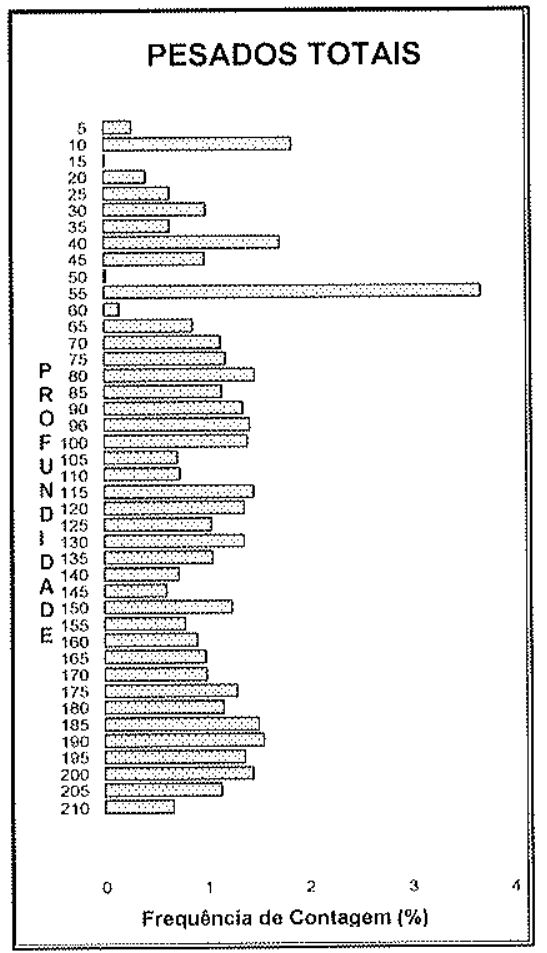

Figura 69- Variação do teor em massa de pesados totais na classe areia muito fina, ao longo do testemunho MV2.
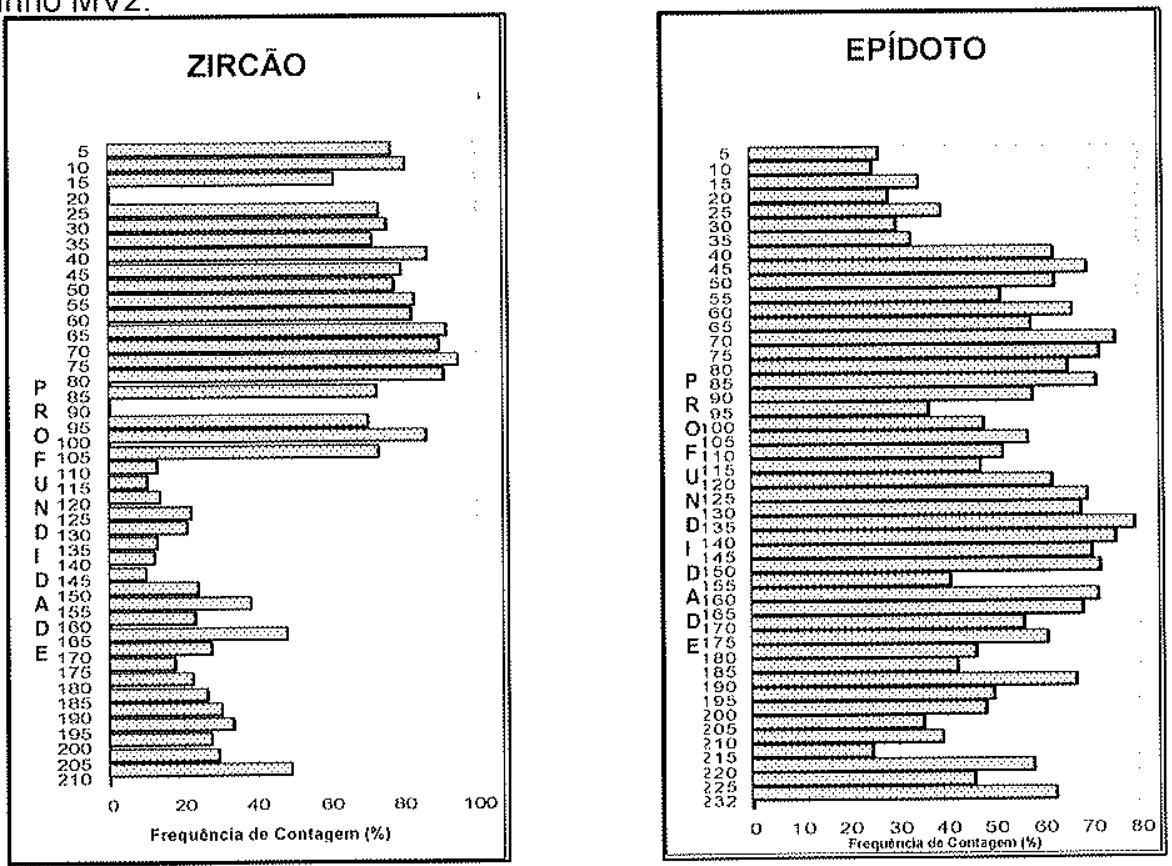

Figura 70-Variaçăo da frequência de contagem de zircão dentre os pesados transparentes não micáceos da classe areia muito fina, ao longo do testemunho MV2.

Figura 71- Variação da frequência de contagem de epídoto dentre os pesados transparentes não micáceos da classe areia muito fina, ao longo do testemunho MV2. 
Outros componentes mineralógicos comuns, com ocorrência na maioria das amostras, e listados na ordem decrescente de concentração média, são: sillimanita (5\%) (Figura 72), alteritas (2\%) (Figura 73), titanita (2\%) (Figura 74), hornblenda (1\%) (Figura 75$)$ e turmalina $(0,2 \%)$ (Figura 76). Mais raramente, e sempre em concentração inferior a $5 \%$ dentre os componentes transparentes não micáceos, encontram-se rutilo, anatásio, granada, scheelita, cianita, zoisita, apatita, estaurolita e tremolita. A maior presença de sillimanita nesta coluna, em comparação com MV1, pode ser atribuída à influência da drenagem contributária existente entre os dois pontos de amostragem. Esta drenagem vem de sul, onde, no cume da serra da Mantiqueira, corta rochas metamórficas pertencentes ao Complexo Piracaia (Figura 3), as quais devem ser a fonte primária de sillimanita.
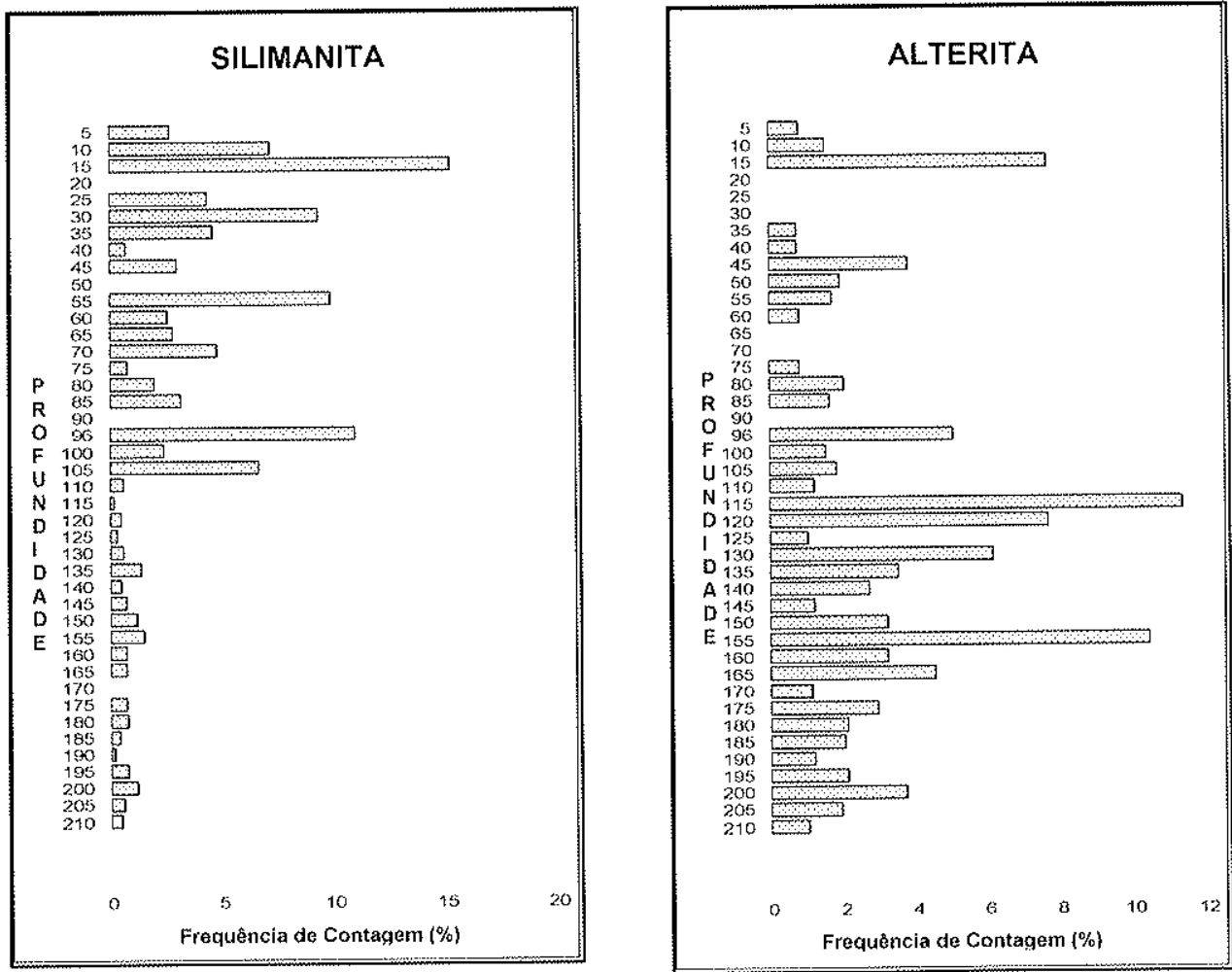

Figura 72- Variação da frequência de contagem de silimanita dentre os pesados transparentes não micáceos da classe areia muito fina, ao longo do testemunho MV2.

Figura 73- Variação vertical da frequência de contagem de alterita dentre os pesados transparentes não micáceos da classe areia muito fina, ao longo do testemunho MV2. 


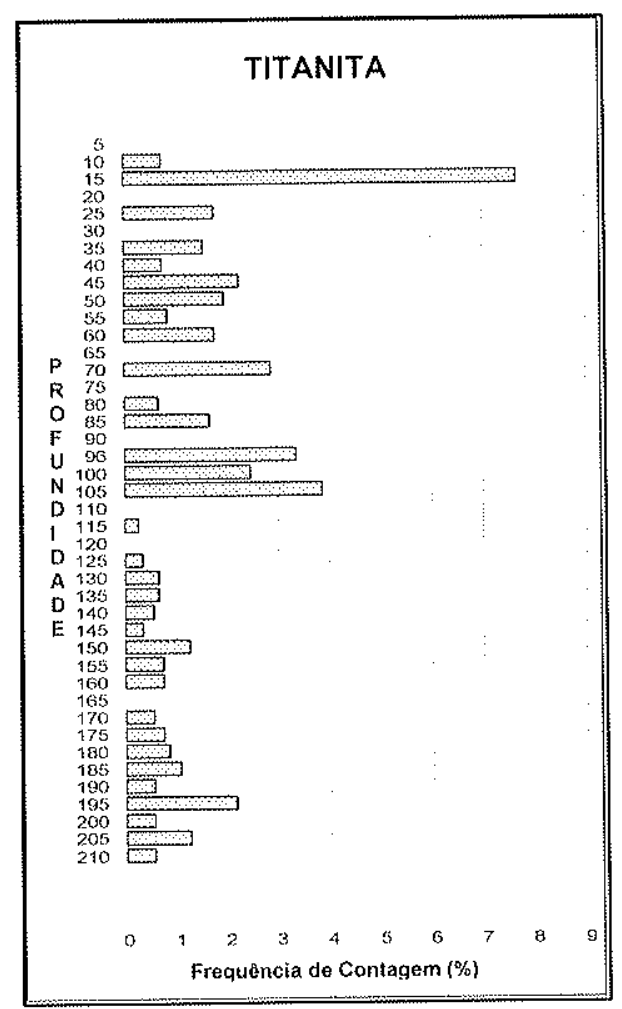

Figura 74- Variação da frequência de contagem de titanita dentre os pesados transparentes não micáceos da classe areia muito fina, ao longo do testemunho MV2.
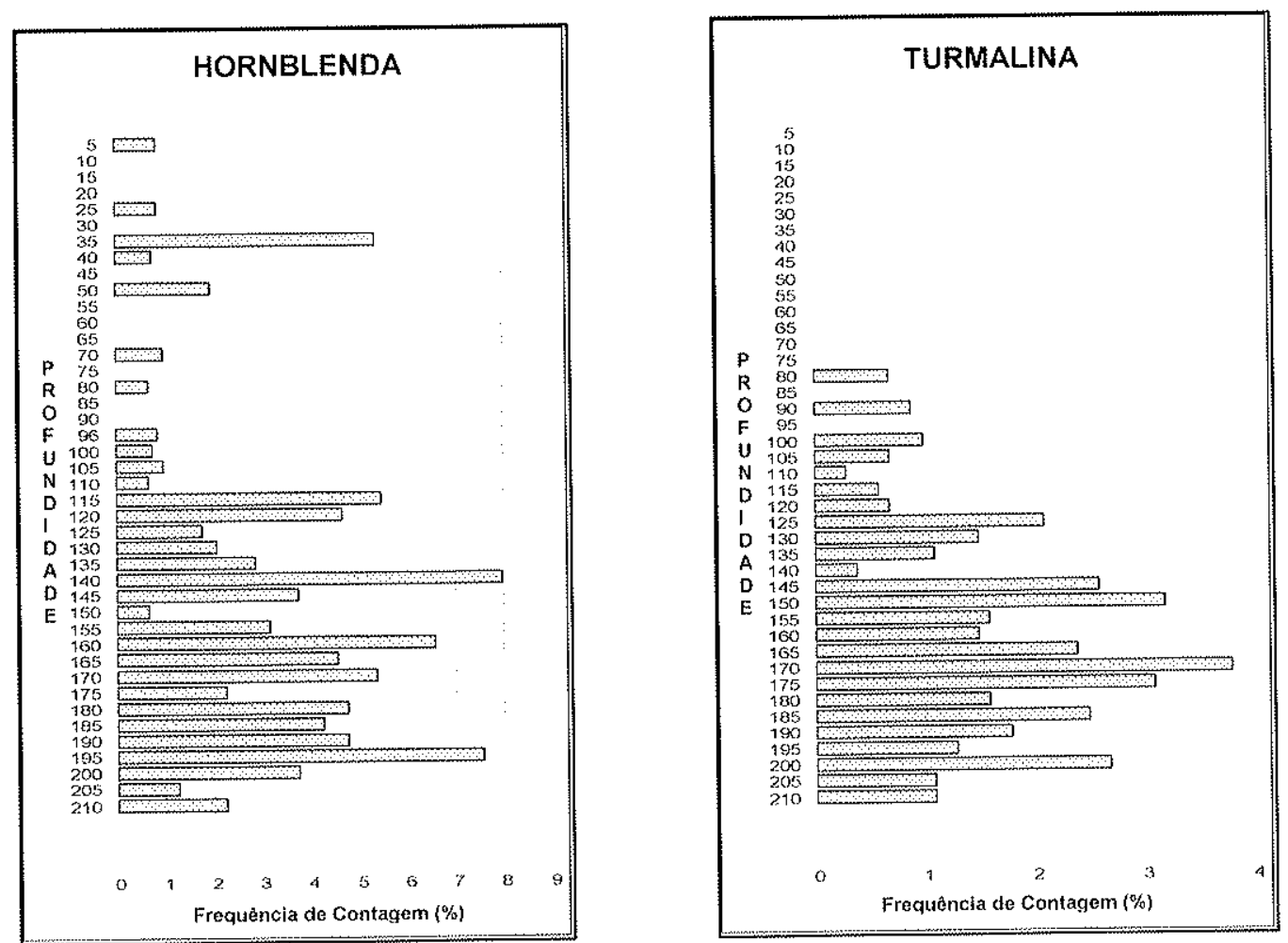

Figura75- Variação da frequência de contagem de hornblenda dentre os pesados transparentes não micáceos da classe areia muito fina, ao longo do testemunho MV2.

Figura 76-Variação da frequência de contagem de turmalina dentre os pesados transparentes não micáceos da classe areia muito fina, ao longo do testemunho MV2. 
Outros minerais que aumentam sua concentração nesta coluna são zircão e titanita, os quais compõem, portanto, juntamente com sillimanita, a assembleia indicadora da influência de rochas metamórficas. Isto é confirmado pela sintonia de variação na concentração destes três minerais, todos enriquecidos na parte superior do testemunho MV2 (acima de $110 \mathrm{~cm}$ ). Em contraposição, os minerais relativamente enriquecidos na parte inferior da coluna sedimentar MV2 são os mesmos que dominam ou ocorrem em maiores concentrações na assembleia de MV1, onde a drenagem corta essencialmente granitos. Esta assembleia é formada por epidoto, hornblenda e turmalina.

Minerais opacos (Figura 77) ocorrem em todas as amostras, com concentração variável entre 1 e $70 \%$ (média de 12\%) em valores de contagem. Dentre os semi-opacos, agregados de leucoxênio e material argilo-limonítico (Figura 78) encontram-se na grande maioria das amostras, com concentrações de até $20 \%$ e $3 \%$ da fração pesada não magnética, respectivamente. Diferentemente do visto em MV1, as maiores concentrações de limonita (Figura 79) estão na base da coluna e não no topo. Isto poderia indicar que em MV2, a pedogênese atual possa se dar em condições pouco oxidantes, provavelmente pela saturação do terreno em água, mas que essa condição já foi diferente, quando da sedimentação do intervalo inferior, mais arenoso. Deve-se frisar, porém, que o enriquecimento em limonita e leucoxênio na parte inferior da coluna acompanha a assembleia indicadora de rocha fonte granítica, o que permite interpretar que a presença destes componentes semi-opacos possa ser controlada antes por uma questão de fonte sedimentar que de alteração no sítio deposicional. Assim, é possível que o fornecimento a partir de rocha granítica seja relativamente enriquecido nestes componentes. Neste caso, é possivel interpretar que este fornecimento seja diretamente (com pouco retrabalhamento posterior) a partir do manto de intemperismo dos granitos, onde a presença de leucoxênio e limonita é esperada. 


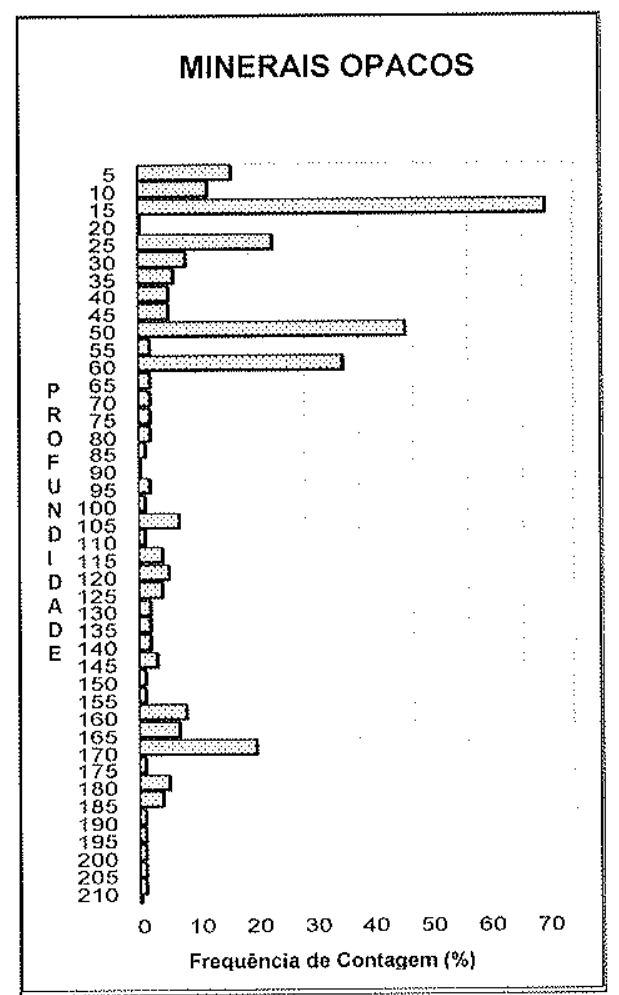

Figura 77- Variação da frequência de contagem de minerais opacos na fração pesada não magnética da classe areia muito fina, ao longo do testemunho MV2.
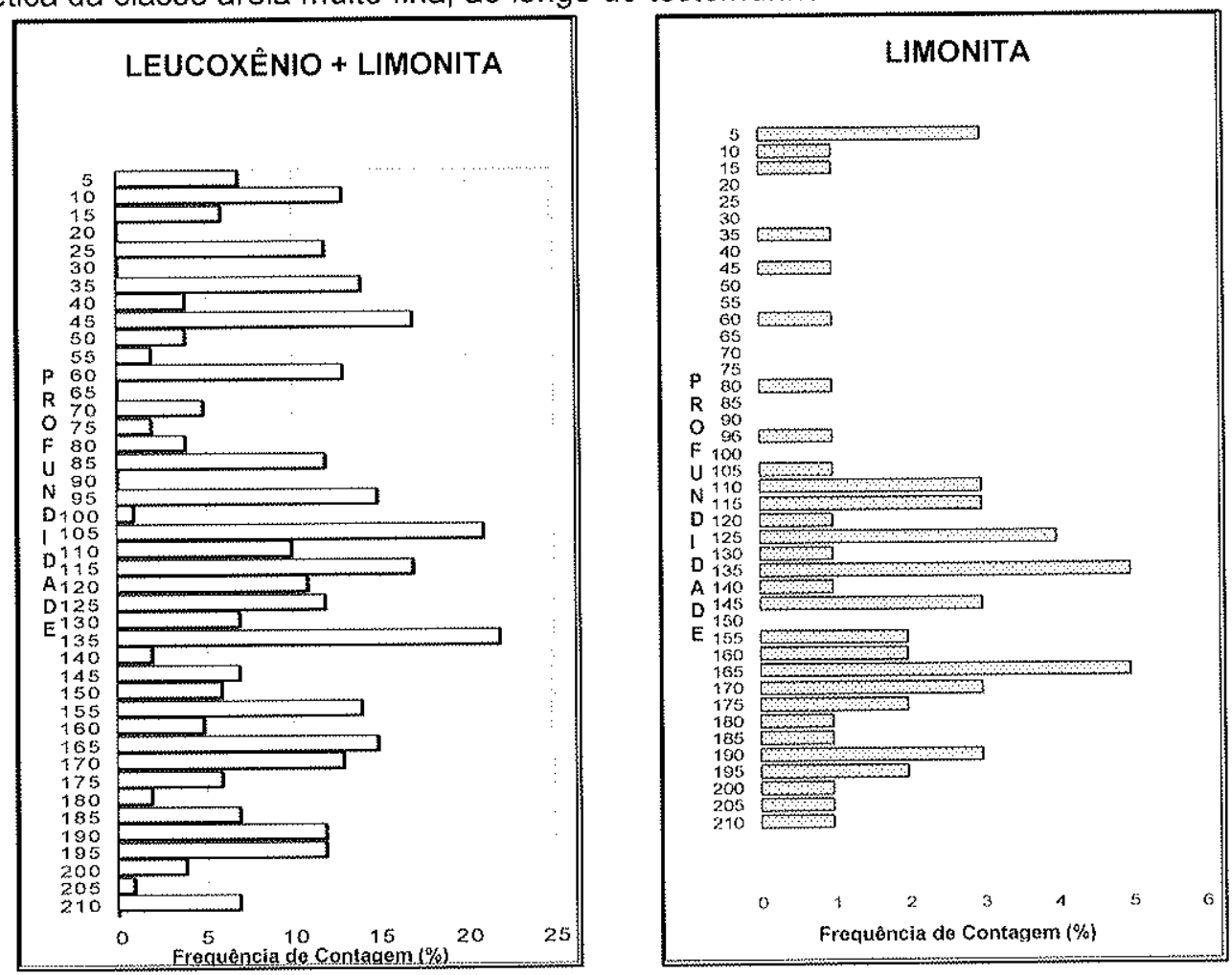

Figura 78- Variação da frequência de contagem de agregados de leucoxênio mais limonita na fração pesada não magnética da classe areia muito fina, ao longo do testemunho MV2.

Figura 79. Variação da frequência de contagem de agregados de limonita na fração pesada não magnética da classe areia muito fina, ao longo do testemunho MV2. 
Os intervalos da coluna sedimentar assinalados como de aumento relativo na concentração de classes granulométricas mais grossas (10 a $15 \mathrm{~cm}$ e 170 a $210 \mathrm{~cm}$ ) apresentam apenas ligeiro aumento também no teor de pesados, na proporção de opacos e, ainda menos acentuadamente, na concentração de zircão e nos índices ZE (Figura 80) e ZTR (Figura 81). Não fica bem evidenciada, portanto, a possivel correlação dos pulsos de competência do transporte de grãos mais grossos com a concentração de componentes mineralógicos mais densos, como sugerido nos resultados de MV1. Os mesmos intervalos apresentam porém aumento na concentração de limonita, leucoxênio e opacos, o que permite apontar para aumento da influência da fonte granítica.
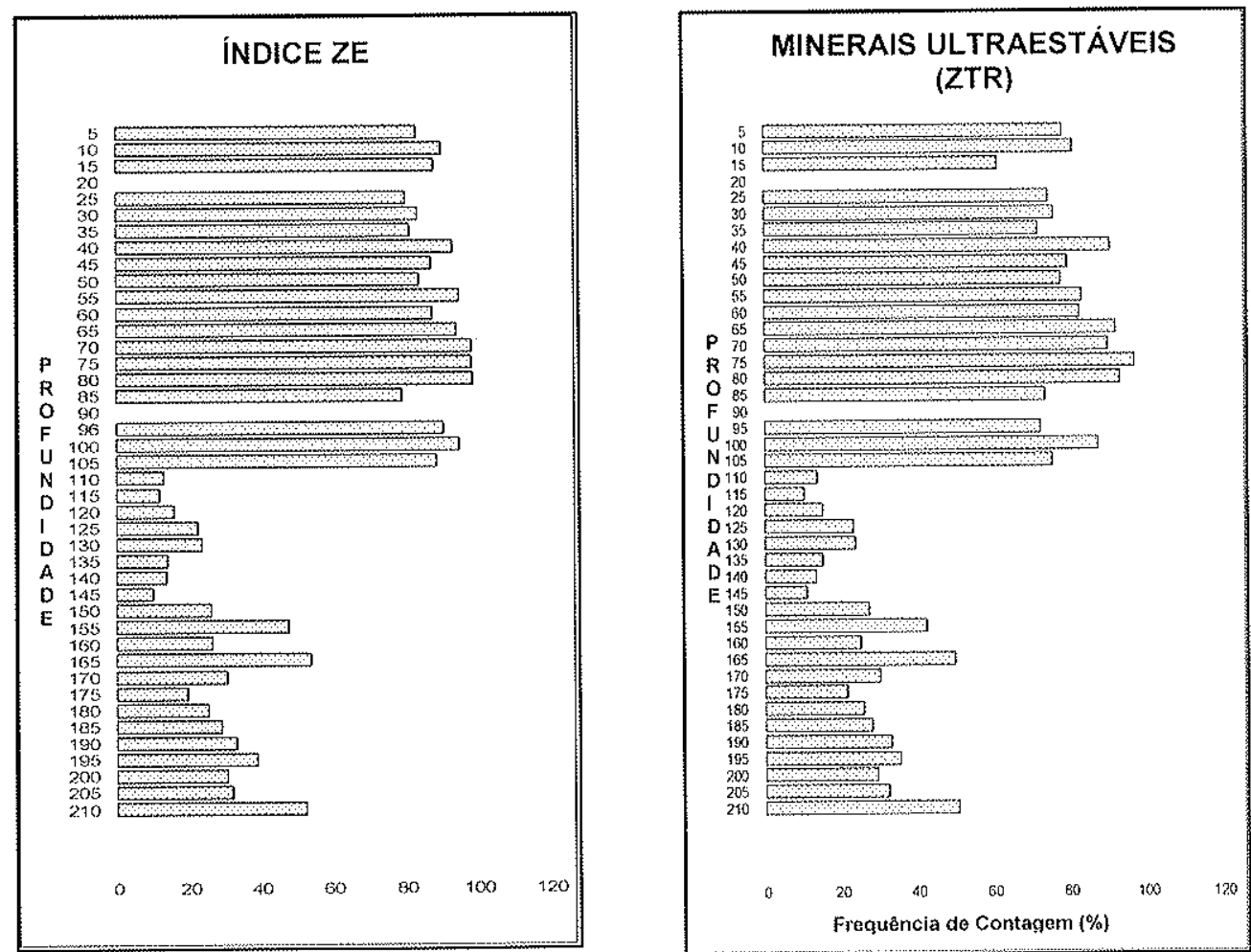

Figura 80-Variação do índice ZE, baseado nas frequências de contagem de zircão e epidoto, na classe areia muito fina, ao longo do testemunho MV2.

Figura 81- Variação da frequência de contagem de minerais ultraestáveis dentre pesados transparentes não micáceos (índice ZTR) da classe areia muito fina, ao longo do testemunho MV2.

Os resultados de distribuição de minerais pesados mostram compartimentação muito clara da coluna sedimentar de MV2 na profundidade de $105 \mathrm{~cm}$, o que coincide de modo aproximado com o limite de fácies entre areia lamosa, abaixo, e lama arenosa, acima, observado na descrição do testemunho, bem como com o horizonte com o máximo teor de argila quantificado em 
laboratório. A parte inferior da coluna sedimentar, com maior relação areia/argila, distingue-se claramente da superior pelas maiores proporções de componentes tipicamente menos densos como hornblenda, epídoto, turmalina, alterita e índice TZ (Figura 82), além dos já mencionados agregados argilo-limoníticos, e pelo relativo empobrecimento em componentes mais densos: zircão, titanita, pesados magnéticos, opacos e índice ZE.

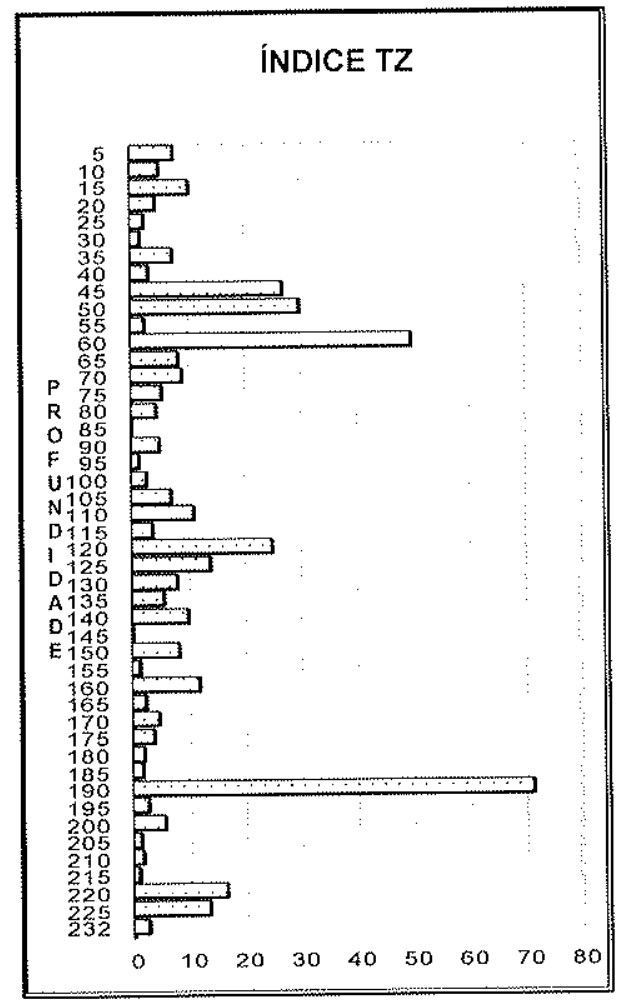

Figura 82- Variação do indice TZ, baseado nas frequências de contagem de turmalina e zircão, na classe areia muito fina, ao longo do testemunho MV2.

Não existe portanto correlação positiva entre a razão areia/argila e a concentração de componentes mineralógicos de elevada densidade, pelo menos não nesta escala de comparação (entre a metade inferior e a superior do testemunho). Isto permite interpretar que as discrepâncias entre estas duas porções da coluna resulte não somente de uma questão de fácies e dinâmica sedimentar, mas também de area fonte imediata, hipótese reforçada pelo evidente contraste nas respectivas assembleias de pesados. Por exemplo, a porção inferior da coluna, onde dominam os minerais índices de fonte próxima, e com composição granítica, poderia corresponder a uma sedimentação mais influenciada por processos locais, como fluxos de encosta e/ou dinâmica fluvial 
associada a drenagem mais próxima, vinda de leste. Enquanto isso, a porção superior da coluna seria influenciada por dinâmica fluvial mais regional $e$, portanto, por áreas fontes (inclusive com rochas metamórficas) mais distantes. A favor desta hipótese, deve-se notar que a porção da coluna MV2 mais parecida mineralogicamente com a MV1, coletada ao lado do canal fluvial a leste, é justamente a inferior.

\section{b) Padrões de variação vertical}

A coluna sedimentar de MV2 divide-se em quatro trechos quanto à tendência de variação vertical das medidas granulométricas da fração areia: de 210 a $180 \mathrm{~cm}$, de 180 a $135 \mathrm{~cm}$, de 135 a $110 \mathrm{~cm}$, e de $110 \mathrm{~cm}$ ao topo. Estes quatro trechos apresentam correlação grosseira com parte das fácies identificadas (Figura 19). Subdividem-se em três tipos de comportamento da granulometria de baixo para cima na coluna sedimentar. O comportamento I, encontrado nos intervalos de 210 a $180 \mathrm{~cm}$ e de 180 a $135 \mathrm{~cm}$, corresponde ao padrão de variação de McLaren da fração areia também já detectado em MV1: melhora de grau de seleção, acompanhada de afinamento do diâmetro médio, com assimetria cada vez mais negativa. O padrão de variação $I I$, encontrado de baixo para cima de 135 a $110 \mathrm{~cm}$, é de piora de seleção, com engrossamento do tamanho médio e assimetria mais negativa. O padrão III, com granulometria cada vez mais selecionada, mais grossa e de distribuição assimétrica mais positiva, equivale ao segundo padrão de McLaren indicador de transporte ou retrabalhamento, e ocorre de $110 \mathrm{~cm}$ ao topo.

Os padrões de variação I e III, coincidentes com os dois padrões de McLaren, são indicadores de aumento no tempo de distalidade ou de redução da influência da fonte. No entanto, | associa-se a retenção seletiva de grossos na fonte, portanto com perda gradual da competência de transporte, enquanto III pressupõe transporte preferencial de grossos, e elevação no tempo dessa competência. Existe portanto entre eles uma diferença de tipo de processo deposicional, e que, neste caso, sabe-se estar relacionada a mudança de área fonte, inicialmente exclusivamente próxima, granítica, e, num segundo momento, também distante, metamórfica. Assim, o padrão I deve estar mais provavelmente ligado a transporte e deposição por tração e decantação, via dinâmica fluvial local, 
e III mais controlado pela dinâmica fluvial regional. O comportamento II, por não corresponder nem a padrão de McLaren, nem a seu inverso, é de difícil interpretação em termos hidrodinâmicos. Pode todavia corresponder ao registro de fluxo de massa de encosta. Esta hipótese é reforçada pelo fato de o trecho com comportamento II abranger a fácies de areia lamosa com gradação inversanormal (Figura 19), trama típica de fluxos de detritos coesivos.

O primeiro trecho com padrão de variação I apresenta algumas tendências bem definidas de variação mineralógica de baixo para cima, tais como aumento de turmalina, epídoto, hornblenda, opacos e dos índices MET, INS e TZ e redução de zircão, titanita, pesados magnéticos e dos índices ZTR e ZE. Com exceção dos opacos, este padrão de variação caracteriza aumento para cima de minerais relativamente menos densos e, portanto, é compatível com a hipótese de elevação da distalidade ao longo do tempo. O segundo trecho com padrão de variação I caracteriza-se por aumento de turmalina e dos índices MET e INS e por queda de pesados não magnéticos, teor de pesados, opacos e dos índices ZTR e $Z E$. A exemplo do trecho basal, é sugestivo de elevação de distalidade no tempo.

$\mathrm{Em}$ termos de variação vertical da mineralogia, o comportamento II associa-se a aumento de teor de pesados, pesados não magnéticos, zircão, epídoto, hornblenda, leucoxênio, MET, INS e queda de turmalina, titanita, ZTR, ZE e TZ. Uma vez que minerais de densidades discrepantes apresentam o mesmo tipo de comportamento, o controle da mineralogia aqui parece ser antes por mudança de área fonte e/ou por alteração diferencial de que por seleção hidráulica. Esta interpretação é reforçada pelo fato de que o intervalo com padrão II, entre 135 e $110 \mathrm{~cm}$, concentra alguns dos maiores valores de alterita, limonita e leucoxênio, todos minerais típicos de alteração, sobretudo em condições oxidantes. A presença destes minerais permitiria em tese cogitar a hipótese de que este intervalo representasse um paleossolo, ou um momento com redução na taxa de sedimentação, no final da fase de sedimentação mais arenosa. No entanto, esta redução na taxa de sedimentação não se confirma nos resultados das Tabelas 4 à 7 (Anexos VIII à XI). Além disso, a presença de paleossolo favoreceria aumento nos índices $A B i$ de maturidade mineralógica ( $\mathrm{SH}$ e $\mathrm{TH}$ ), 0 que também não se observa. Assim, é mais provável que o aumento de produtos de alteração (leucoxênio, limonita, alterita), deva-se simplesmente ao aporte 
direto, com pouco retrabalhamento, a partir do manto de intemperismo de rocha granítica, o que reforça a hipótese de deposição por fluxo de detritos coesivo.

O padrão III, da porção superior do testemunho, é acompanhado pelas seguintes tendências de variação vertical da mineralogia, de baixo para cima: aumento de opacos, epídoto, MET e INS e redução de teor em massa de pesados e das frequências de contagem de pesados magnéticos, zircão, titanita, ZTR e ZE. A exemplo do intervalo basal com padrão I, esta variação, exceto pelos opacos, caracteriza aumento para cima de minerais relativamente menos densos, o que é difícil de compatibilizar com a tendência de engrossamento ascendente. O mais provável, portanto, é que se trate aqui, antes de controle por mudança de fonte, com influência cada vez menor da fonte metamórfica distal, que de uma questão meramente de seleção hidráulica por densidade.

\subsection{Análise geoquímica e isotópica}

Os resultados de análise geoquímica e isotópica, obtidos para todas as amostras dos testemunhos MV1 e MV2 acima de $160 \mathrm{~cm}$, encontram-se organizados por profundidade, nas tabelas 10 e 11.

A partir destes dados, foram confeccionados gráficos de variação vertical (Figuras 83 a 94), nos moldes do já apresentado para os resultados de granulometria, minerais pesados e palinologia.

Tabela 10-Resultados geoquímicos e isotópicos obtidos no testemunho MV1.

\begin{tabular}{|c|c|c|c|c|}
\hline Profundidades $(\mathrm{cm})$ & $C_{\text {total }}(\%)$ & $\delta^{13} \mathrm{C}(\%)$ & $N_{\text {total }}(\%)$ & $\delta^{15} \mathrm{~N}(\%)$ \\
\hline $0-5$ & 6,92 & $-23,82$ & 0,42 & 5,98 \\
\hline $5-10$ & 5,82 & $-23,21$ & 0,27 & 5,89 \\
\hline $10-15$ & 7,58 & $-23,84$ & 0,46 & 5,78 \\
\hline $15-20$ & 9,18 & $-23,95$ & 0,56 & 5,58 \\
\hline $20-25$ & 13,57 & $-24,16$ & 0,8 & 5,54 \\
\hline $25-30$ & 11,95 & $-24,18$ & 0,69 & 6,38 \\
\hline $30-35$ & 9,75 & $-23,98$ & 0,56 & 6,14 \\
\hline $35-40$ & 8,89 & $-23,69$ & 0,46 & 6,59 \\
\hline $40-45$ & 12,86 & $-18,53$ & 0,48 & 6,81 \\
\hline $45-50$ & 13,10 & $-19,13$ & 0,53 & 6,39 \\
\hline $50-55$ & 13,20 & $-19,11$ & 0,52 & 6,38 \\
\hline $55-60$ & 10,57 & $-23,13$ & 0,39 & 5,64 \\
\hline $60-65$ & 9,62 & $-23,14$ & 0,33 & 5,57 \\
\hline $65-70$ & 10,03 & $-22,40$ & 0,32 & 4,82 \\
\hline $70-75$ & 33,76 & $-19,94$ & 0,15 & 5,34 \\
\hline
\end{tabular}




\begin{tabular}{|c|c|c|c|c|}
\hline $75-80$ & 14,39 & $-21,07$ & 0,51 & 5,06 \\
\hline $80-85$ & 6,53 & $-20,54$ & $0,2\}$ & 4,71 \\
\hline $85-90$ & 6,56 & $-21,89$ & 0,27 & 4,95 \\
\hline $90-95$ & 7,26 & $-23,70$ & 0,24 & 5,57 \\
\hline $95-100$ & 5,91 & $-26,09$ & 0,17 & 2,98 \\
\hline $100-105$ & 7,61 & $-26,34$ & 0,21 & 3,33 \\
\hline $105-110$ & 15,58 & $-26,78$ & 0,35 & 3,27 \\
\hline $110-115$ & 12,37 & $-26,34$ & 0,33 & 3,97 \\
\hline $115-120$ & 11,80 & $-26,23$ & 0,32 & 3,58 \\
\hline $120-125$ & 12,84 & $-26,15$ & 0,41 & 3,61 \\
\hline $125-130$ & 12,87 & $-26,15$ & 0,41 & 3,34 \\
\hline $130-135$ & 14,71 & $-26,33$ & 0,47 & 3,97 \\
\hline $135-140$ & 13,41 & $-26,40$ & 0,38 & 3,46 \\
\hline $140-145$ & 14,62 & $-26,57$ & 0,45 & 2,63 \\
\hline $145-150$ & 11,10 & $-26,36$ & 0,38 & 2,84 \\
\hline $150-155$ & 19,53 & $-26,41$ & 0,58 & 2,75 \\
\hline $155-160$ & 8,47 & $-26,54$ & 0,23 & 3,26 \\
\hline
\end{tabular}

O coeficiente de determinação $\left(R^{2}\right)$ da correlação linear entre $C_{\text {org }}$ e $N_{\text {total }}$ no testemunho MV1 é de 0,315 (Figura 83), com nível de confiança de 0,005 (0,5\% de probabilidade de a correlação ser inexistente). Isso demonstra que os dois elementos analisados, e seus isótopos, possuem origem de fato orgânica, o que de acordo com Hedges et al. (1986), permite sua utilização nas interpretações sobre a fonte da matéria orgânica presente nos sedimentos.

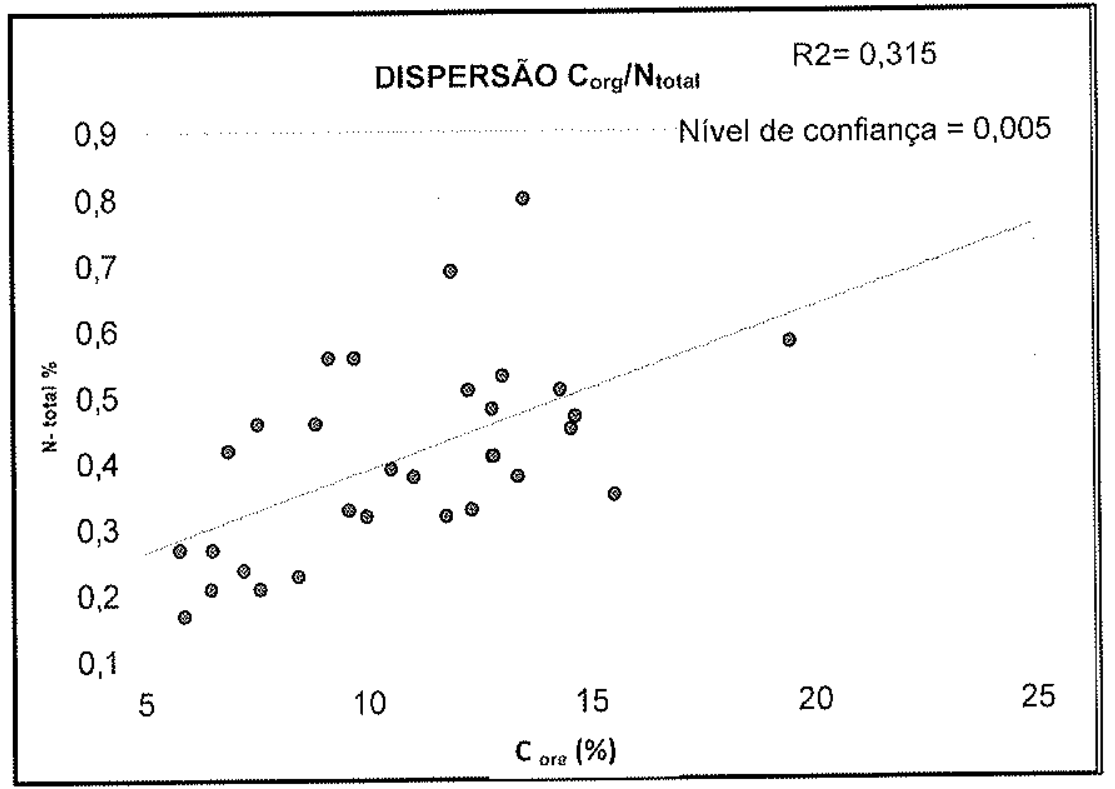

Figura 83- Dispersão $C_{\text {org }} / N_{\text {total }}$ no testemunho MV1 


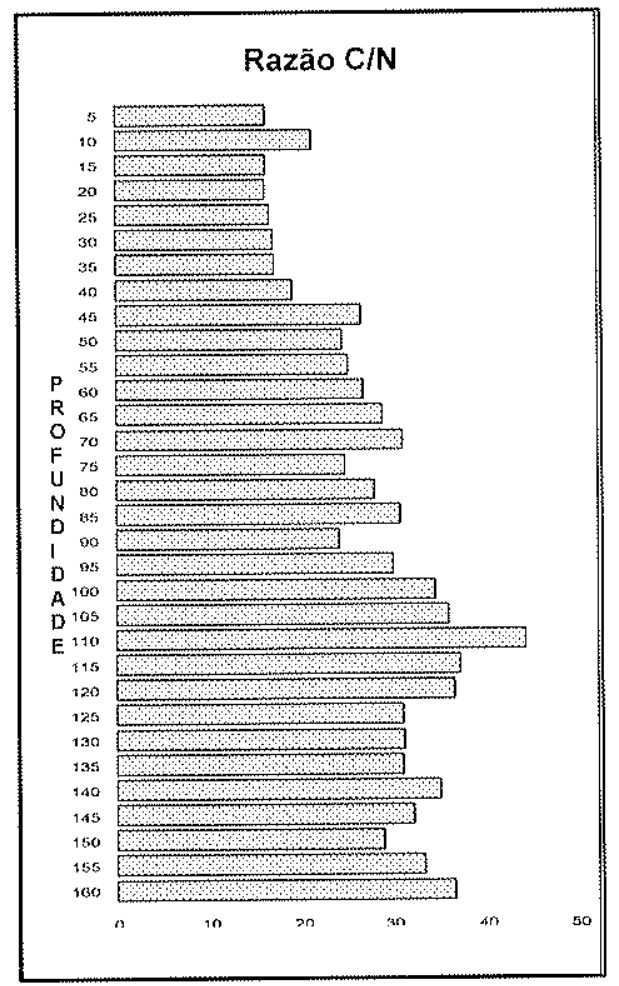

Figura 84- Razão C/N ao longo do testemunho MV1.

Tabela 11- Resultados geoquimicos e isotópicos obtidos no testemunho MV2.

\begin{tabular}{|c|c|c|c|c|}
\hline Profundidades $(\mathrm{cm})$ & $\mathrm{C}_{\text {total }}(\%)$ & $\delta^{13} \mathrm{C}(\% 0)$ & $\mathrm{N}_{\text {total }}(\%)$ & $\delta^{15} \mathrm{~N}(\% 0)$ \\
\hline $0-5$ & 8,56 & $-23,80$ & 0,49 & 7,78 \\
\hline $5 \cdot 10$ & 12,07 & $-23,73$ & 0,67 & 6.97 \\
\hline $10-15$ & 11,78 & $-22,92$ & 0,60 & 7,08 \\
\hline $15-20$ & 11,93 & $-21,05$ & 0,52 & 7,49 \\
\hline $20-25$ & 8,78 & $-19,84$ & 0,35 & 7,03 \\
\hline $25 \cdot 30$ & 12,78 & $-20,70$ & 0,51 & 6,61 \\
\hline $30-35$ & 13,40 & $-21,10$ & 0,51 & 6,56 \\
\hline $35-40$ & 12,98 & $-21,05$ & 0,47 & 6,50 \\
\hline $40-45$ & 11,19 & $-20,46$ & 0,40 & 6,32 \\
\hline $45-50$ & 9,46 & -20.61 & 0,32 & 6,25 \\
\hline $50-55$ & 6,61 & $-21,47$ & 0,22 & 6,13 \\
\hline $55-60$ & 10,49 & $-20,53$ & 0,35 & 5,86 \\
\hline $60-65$ & 9,30 & $-22,25$ & 0,32 & 5,72 \\
\hline $65 \cdot 70$ & 7,83 & $-20,39$ & 0,27 & 5,94 \\
\hline $70 \cdot 75$ & 10,61 & $-21,66$ & 0,37 & 5,39 \\
\hline $75-80$ & 9,25 & $-19,05$ & 0,37 & 6,13 \\
\hline $80-85$ & 10,86 & $-18,64$ & 0,35 & 5,51 \\
\hline $85-90$ & 6,44 & $-25,31$ & 0,22 & 4,03 \\
\hline 90.95 & 9,96 & $-26,95$ & 0,34 & 2,85 \\
\hline $95-100$ & 9,04 & $-26,75$ & 0,28 & 3,19 \\
\hline
\end{tabular}




\begin{tabular}{|c|c|c|c|c|}
\hline $100-105$ & 7,69 & $-26,52$ & 0,26 & 3,27 \\
\hline $105-110$ & 7,17 & $-26,85$ & 0,24 & 3,12 \\
\hline $110-115$ & 5,67 & $-26,80$ & 0,19 & 2,81 \\
\hline $115-120$ & 7,69 & $-24,31$ & 0,24 & 3,54 \\
\hline $120-125$ & 6,14 & $-26,56$ & 0,22 & 3,79 \\
\hline $125-130$ & 6,56 & $-26,63$ & 0,21 & 3,74 \\
\hline $130-135$ & 5,66 & $-26,70$ & 0,16 & 3,54 \\
\hline $135-140$ & 5,59 & $-26,37$ & 0,20 & 3,50 \\
\hline $140-145$ & 5,64 & $-26,19$ & 0,20 & 3,57 \\
\hline $145-150$ & 4,43 & $-26,14$ & 0,17 & 3,95 \\
\hline $150-155$ & 2,78 & $-25,55$ & 0,10 & 4,17 \\
\hline $155-160$ & 3,70 & $-26,05$ & 0,12 & 2,64 \\
\hline $160-165$ & 4,29 & $-25,97$ & 0,14 & 3,28 \\
\hline $165-170$ & 4,27 & $-25,95$ & 0,13 & 3,26 \\
\hline $170-175$ & 2,94 & $-25,71$ & 0,09 & 3,03 \\
\hline $175-180$ & 2,95 & $-25,82$ & 0,08 & 2,07 \\
\hline
\end{tabular}

No testemunho $M V 2$, o coeficiente de determinação $\left(R^{2}\right)$ da correlação linear entre $\mathrm{C}_{\text {org }}$ e $\mathrm{N}_{\text {total }}$ é de 0,847, com nível de confiança de 0,005 (Figura 85), o que também permite admitir a origem essencialmente orgânica dos dois elementos químicos analisados.

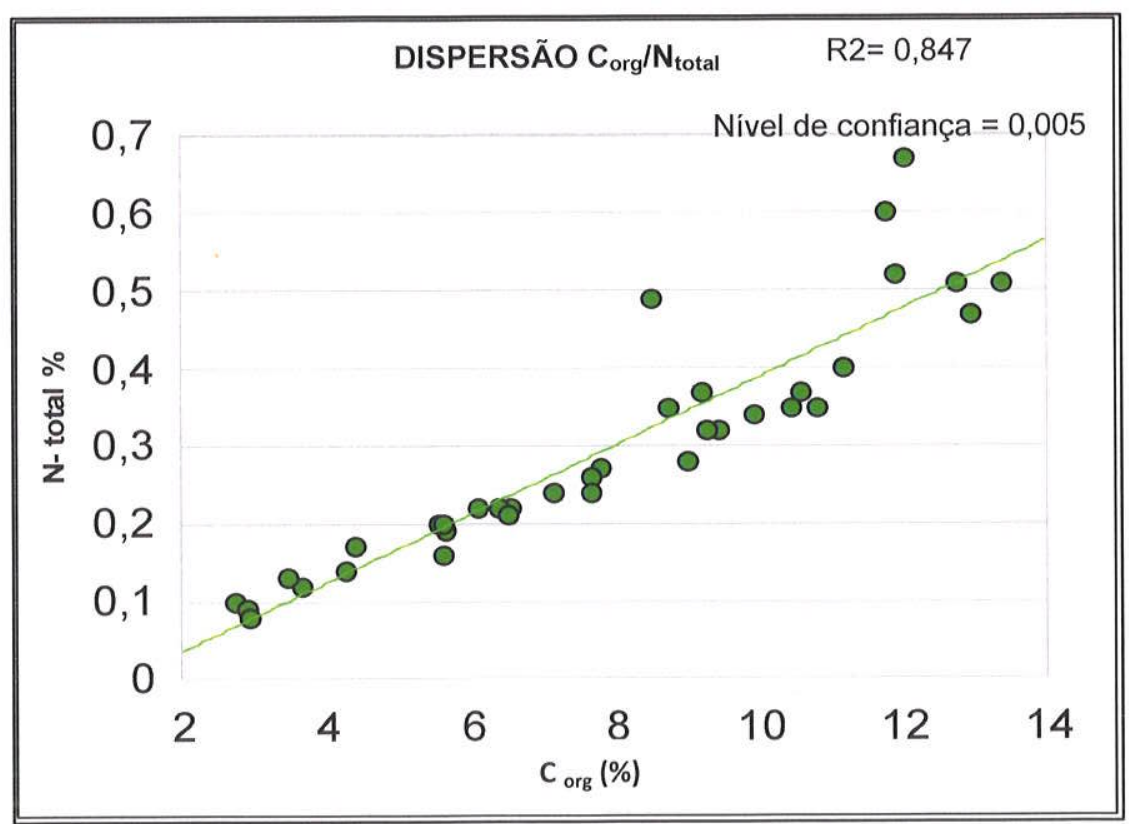

Figura 85- Dispersão de $\mathrm{N}$ total por $\mathrm{C}$ total no testemunho MV2. 


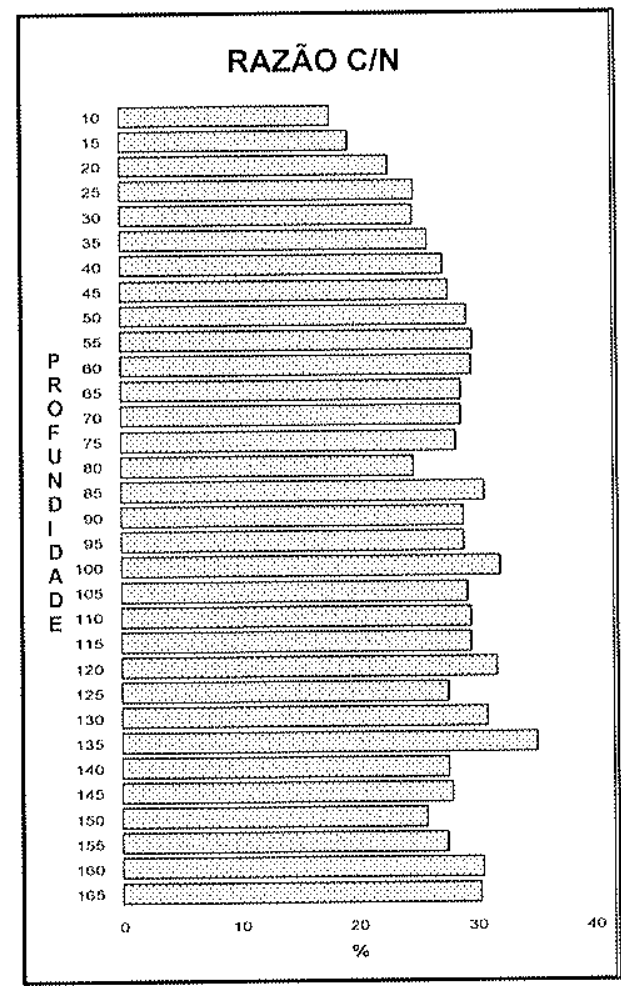

Figura 86- Teores da razão $\mathrm{C} / \mathrm{N}$ ao longo do testemunho MV2.

Os teores de $C_{\text {total }}$ para o testemunho MV1 (Figura 87) apresentam oscilação ao longo de todo perfil, com máxima concentração entre 70 e $75 \mathrm{~cm}$ $(33,76 \%)$ e minima entre 5 e $10 \mathrm{~cm}(5,82 \%)$. A tendência geral é de redução suave da concentração de $\mathrm{C}_{\text {total }}$ para cima, mas com dois intervalos de baixos valores (menores que $8 \%$ ), um entre 105 e $85 \mathrm{~cm}$ e outro nos $20 \mathrm{~cm}$ superiores. Já no testemunho MV2 (Figura 88), existe tendência, mais acentuada, de aumento ascendente no teor de $\mathrm{C}_{\text {total }}$. 

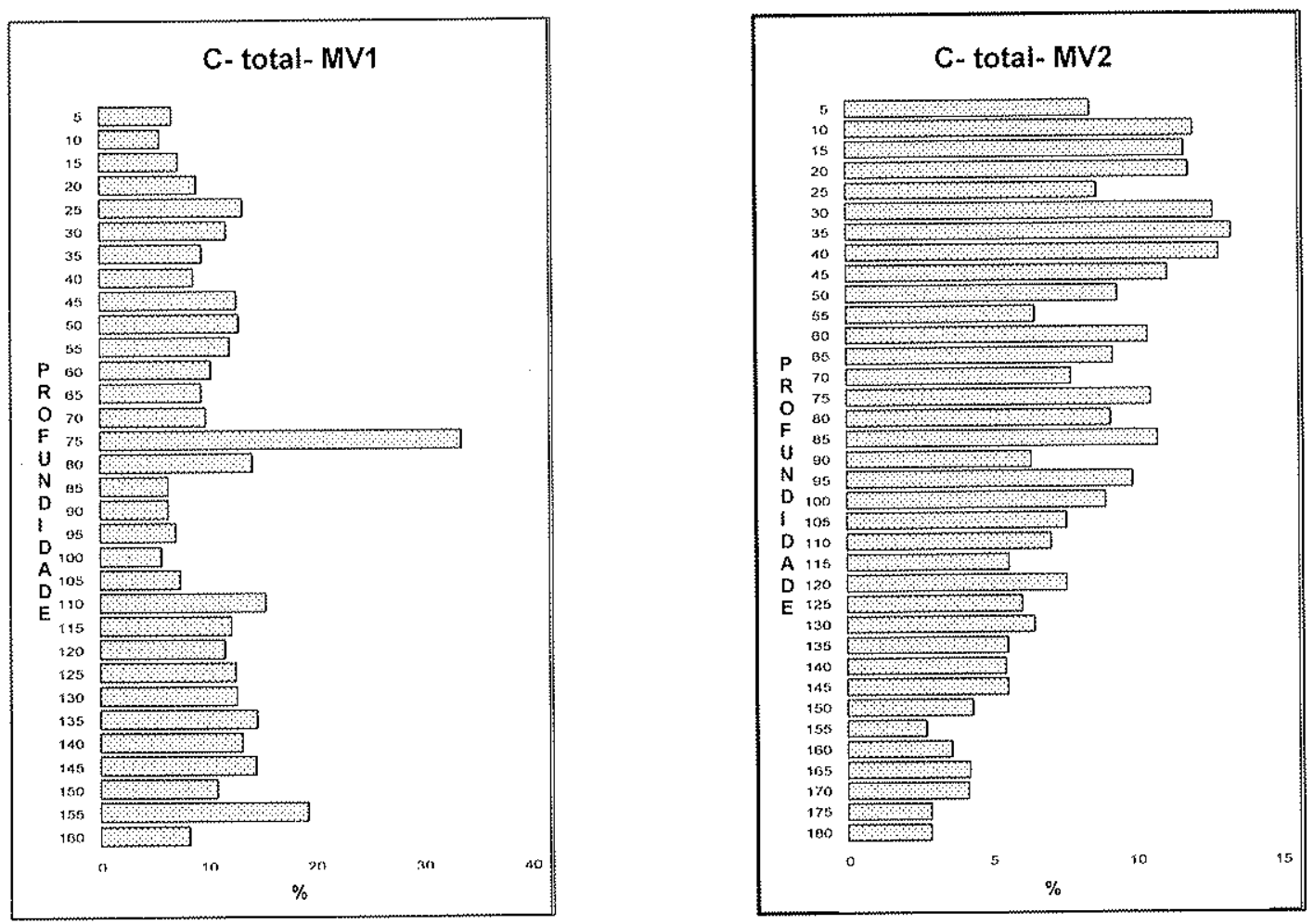

Figura 87- Teores de $\mathrm{C}_{\text {total }}$ ao longo do testemunho MV1.

Figura 88-Teores de $\mathrm{C}_{\text {total }}$ ao longo do testemunho MV2.

Com relação à razão isotópica $\delta^{13} \mathrm{C}$, observaram-se, nas duas colunas, valores da mesma ordem de grandeza, com variação entre -27 e $-18 \%$ (Figuras 89 e 90). A parte mais profunda dos dois perfis (abaixo de 95 a $100 \mathrm{~cm}$ ) apresenta valores de $\delta^{13} \mathrm{C}$ nitidamente mais negativos (menores que $-24 \%$ ) que a porção acima. Em MV1, por exemplo, o $\delta^{13} \mathrm{C}$ nesta parte inferior da coluna varia de $26,54 \%$ (em $160 \mathrm{~cm}$ ) a $-26,09 \%$ (em $95 \mathrm{~cm}$ ). Estes dados são sugestivos de que o período compreendido entre aproximadamente 30000 anos A.P. e 17000 anos A.P. foi dominado por vegetação florestal (predominio de plantas C3). Essa vegetação florestal pode, porém, ter-se tornado mais aberta a partir de então, especialmente nos periodos correspondentes aos intervalos verticais de 95 a 45 cm (cerca de 17000 a 3500 anos A.P.), em MV1, e de 85 a $20 \mathrm{~cm}$ (aproximadamente 16000 a 5000 anos A.P.) em MV2, ambos caracterizados por $\delta^{13} \mathrm{C}$ mais alto. 

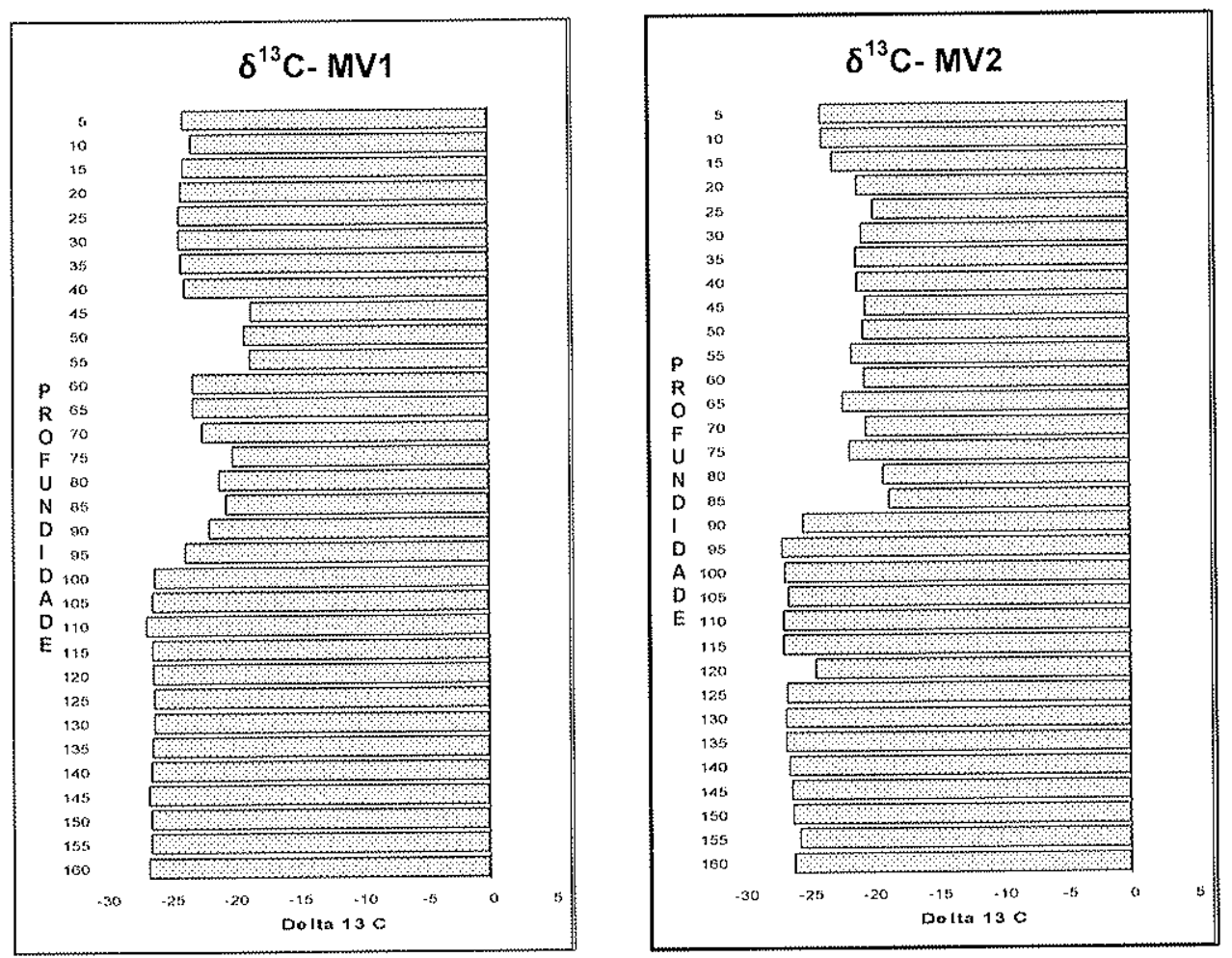

Figura 89- Teores de $\delta{ }^{13} \mathrm{C}$ ao longo do testemunho MV1

Figura 90 - Teores de $\delta{ }^{13} \mathrm{C}$ ao longo do testemunho MV2

Em MV1, o padrão de variação de $N_{\text {total }}$ é de diminuição para cima até a profundidade $95 \mathrm{~cm}$, intervalo datado de cerca de 30000 anos A.P. a 17000 anos A.P., seguida de aumento a partir daí (Figuras 91). Já em MV2 (Figura 92), a tendência geral é de aumento do $\mathrm{N}_{\text {total }}$ com a redução de profundidade, portanto desde 26000 anos A.P.. 

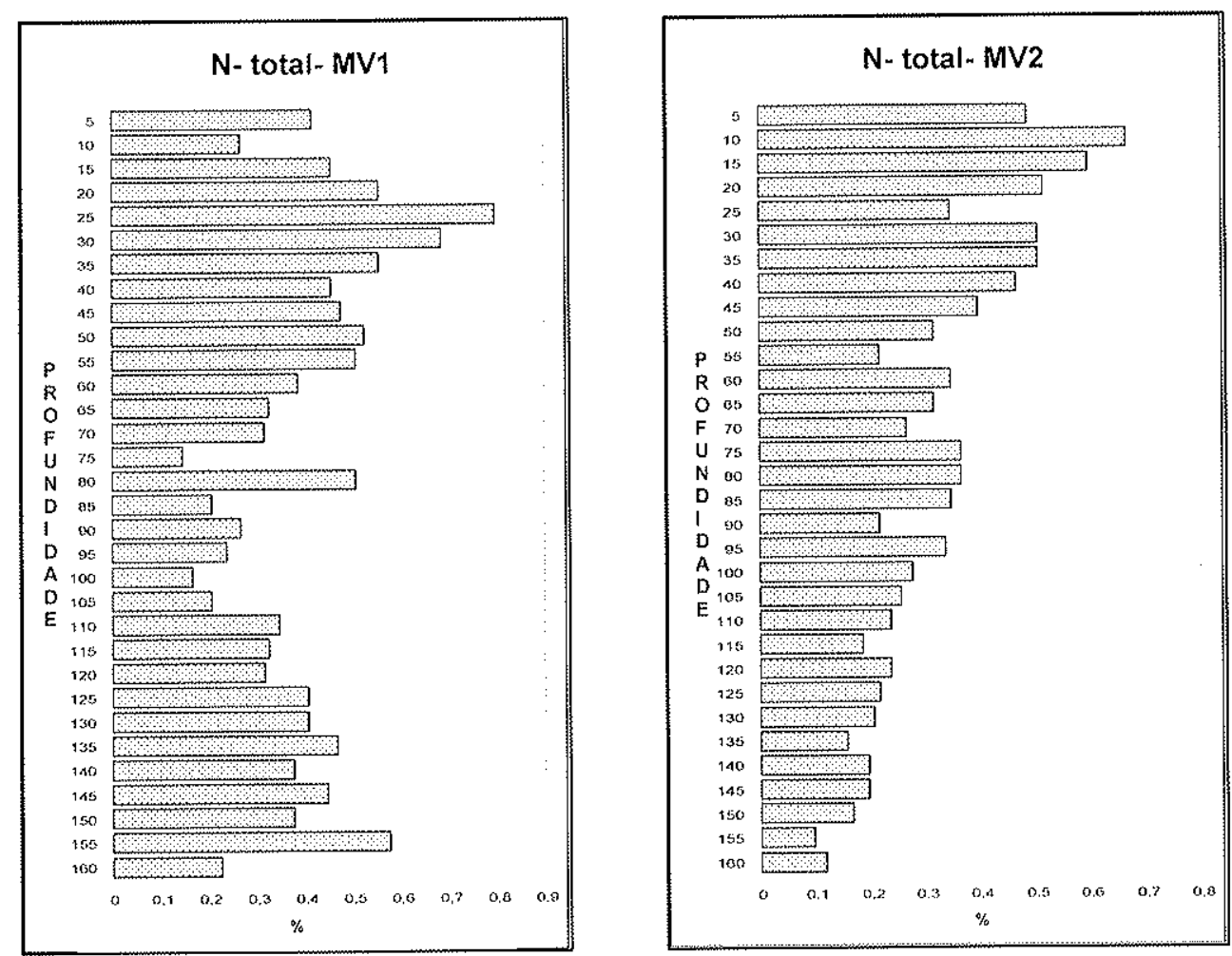

Figura 91- Teores de $\mathrm{N}_{\text {total }}$ ao longo do testemunho MV1.

Figura 92- Teores de $\mathrm{N}_{\text {total }}$ ao longo do testemunho MV2.

O $\delta^{15} \mathrm{~N}$ acompanha esta última tendência apenas na parte superior dos dois testemunhos (Figuras 93 e 94), o que corresponde, em ambos os casos, aos últimos 20000 anos. Os resultados de $\delta^{15} \mathrm{~N}$ encontrados variam entre 2 e $8 \%$, sendo portanto intermediários entre os valores típicos, apontados na literatura, de matéria orgânica ligada a plantas terrestres $(0,4 \%)$ e a algas planctônicas $(8,6 \%)$. $\mathrm{O}$ aumento gradual de $\delta^{15} \mathrm{~N}$ dentro do metro superior dos dois testemunhos, até alcançar no topo valores muito próximos dos típicos de algas, pode indicar intensificação das condiçôes de saturação aquosa dos sedimentos, o que pode estar ligado à variação (elevação) de nivel de base e/ou de cobertura florística, em ambos os casos com ou sem controle climático. 

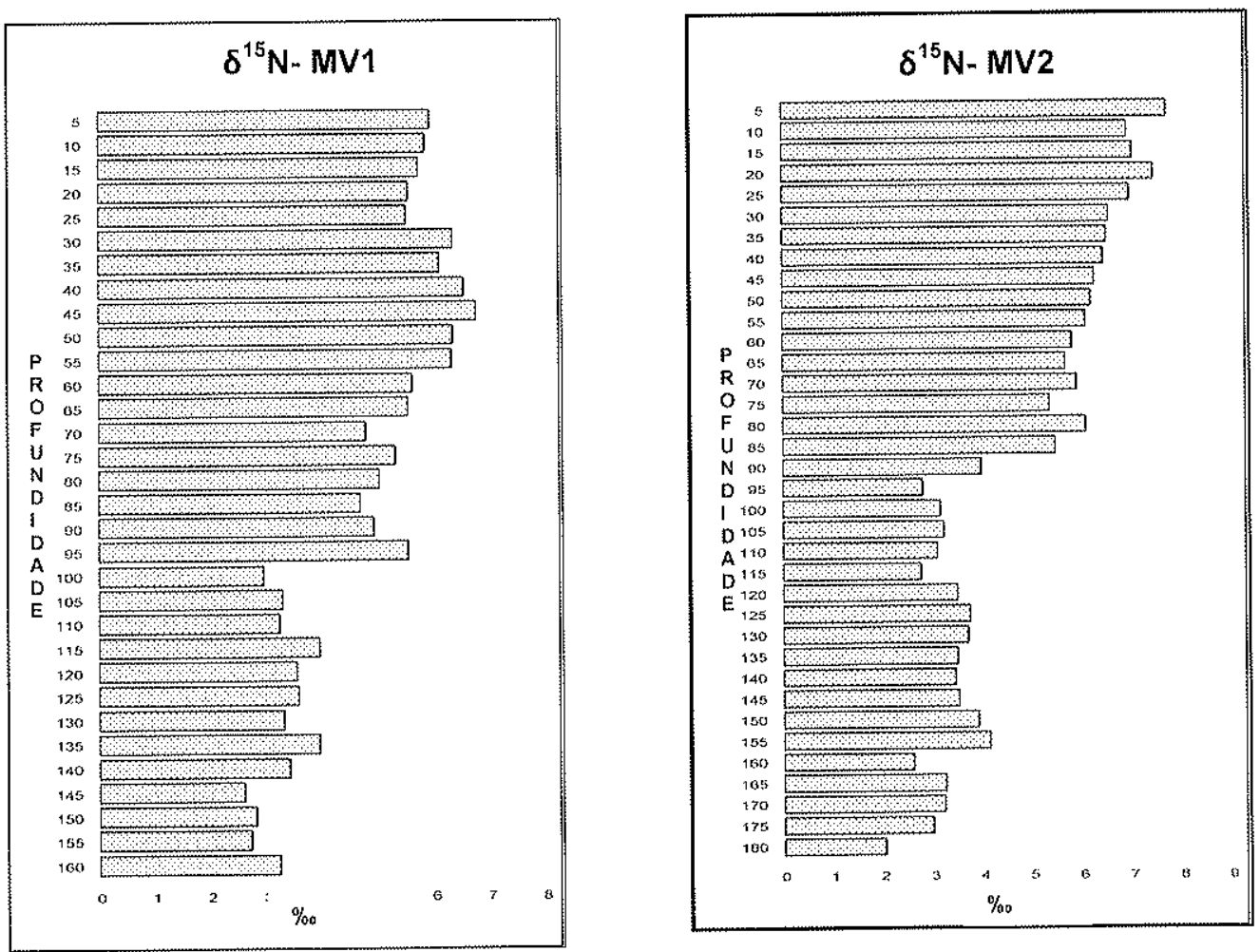

Figura 93- Teores de $\delta{ }^{15} \mathrm{~N}$ ao longo do testemunho MV1.

Figura 94- Teores de $\delta{ }^{15} \mathrm{~N}$ ao longo do testemunho MV2. 


\section{INTEGRAÇÃO E DISCUSSÃO DOS RESULTADOS}

\section{- Testemunho MV1}

A análise integrada dos resultados de análise da coluna sedimentar MV1 permitiu sua subdivisão em dois grandes intervalos. O primeiro inicia-se em 230 $\mathrm{cm}$ de profundidade e termina, dependendo do indicador utilizado, entre 95 e 110 $\mathrm{cm}$ de profundidade, com faixa de idade compreendida entre $38695-40522$ anos cal A.P. e $26260-25370$ anos A.P. (em $110 \mathrm{~cm}$ ). O segundo intervalo, acima de $110 \mathrm{~cm}$, corresponde ao período aproximado de 26000 anos A.P. a 2000 anos A.P. (idade obtida na profundidade $5 \mathrm{~cm}$ ). A subdivisão em $110 \mathrm{~cm}$ coincide com o limite de fácies observado na coluna estratigráfica (Figura 18).

O intervalo inferior corresponde à fácies de lama arenosa muito fina a média com fragmentos de raízes. Apresenta taxas de sedimentação declinantes de baixo para cima, abrangendo, no topo, a taxa mais baixa da coluna sedimentar $(0,002 \mathrm{~cm} / \mathrm{ano})$. De acordo com a análise granulométrica, distingue-se do intervalo superior pelas maiores concentrações de areia fina, areia muito fina e argila e pelas menores de areia grossa a muito grossa. Destaca-se também pelos menores valores de desvio padrão e pelos maiores de assimetria da faixa granulométrica areia. Na mineralogia de pesados, encontram-se neste intervalo as maiores proporções de titanita e hornblenda e os maiores valores do índice $\mathrm{TH}$, bem como as menores concentrações de opacos. Quanto à variação vertical dos atributos sedimentológicos, este intervalo inferior não possui uma tendência geral bem definida. Caracteriza-se, acima de $200 \mathrm{~cm}$ de profundidade (cerca de 37000 anos A.P.), por dois ciclos superpostos de padrão de McLaren com afinamento ascendente, acompanhados de redução de minerais pesados densos, o que sugere distanciamento progressivo (ou redução da influência) da fonte sedimentar.

Os resultados palinológicos deste primeiro intervalo indicam concentração e preservação comparativamente baixas de palinomorfos, com predominio de elementos arbóreos. Araucaria, embora em concentração relativamente escassa (em torno de 100 grãos por $\mathrm{cm}^{3}$, portanto menor do que nas condições atuais com base nas análises de superfície realizadas por Siqueira, 2006), mantém-se estável em todo intervalo, acompanhada de outros elementos de florestas úmidas 
e fechadas de clima subtropical como Podocarpus, llex, Drymis, Myrsine, Symplocos e Myrtaceae.

Os resultados geoquímicos deste intervalo inferior, caracterizado por razão $\mathrm{C} / \mathrm{N}$ dominantemente acima de 30 e $\delta^{15} \mathrm{~N}$ abaixo de $4 \%$, indicam fonte de matéria orgânica terrestre. Valores de $\delta^{13} \mathrm{C}$, menores que $-24 \%$, são sugestivos de contribuição de plantas do tipo $\mathrm{C} 3$ e, portanto, concordam com a interpretação de condições de florestas fechadas.

As baixas taxas de sedimentação, a distribuição granulométrica pobre nas frações extremas mais grossas, a concentração de pesados menos densos (isto é, hornblenda) em detrimento de mais densos (como opacos) e a maturidade mineralógica mais elevada, sugerida pelo índice $\mathrm{T} / \mathrm{H}$, permitem propor um contexto de sedimentação lenta, de baixa energia, com prolongada exposição a agentes intempéricos de dissolução. Em vista deste quadro e das características da área de coleta, o contexto deposicional deste primeiro intervalo seria de planície de inundação fluvial distal, em relação ao canal e às áreas com cobertura árbórea mais bem desenvolvida, provavelmente situadas nas encostas. Dois ciclos sedimentares com padrão de McLaren com afinamento ascendente associam-se a aumento da distalidade, o que, em vista das taxas de sedimentação declinantes, pode ter sido uma tendência dominante neste intervalo inferior.

Sob processo de sedimentação lento, a prolongada exposição a agentes intempéricos, sugerida pelos resultados sedimentológicos, teria contribuído para a menor concentração de palinomorfos e para seu grau de preservação relativamente baixo, haja vista a maior frequência e intensidade de sinais de corrosão de grãos de pólen e esporos.

O segundo intervalo (110/95 - $0 \mathrm{~cm}$, aproximadamene últimos 26000 anos) corresponde à fácies lama arenosa muito fina a grossa. Inclui o trecho com maior taxa de sedimentação na coluna $(0,02 \mathrm{~cm} / \mathrm{ano}$, de 80 a $10 \mathrm{~cm}$ de profundidade), mas apresenta, a exemplo do anterior, declinio dessa taxa no tempo. Do ponto de vista granulométrico, distingue-se pelas maiores concentrações de areia grossa a muito grossa, em detrimento das frações areia fina, areia muito fina e argila. Os valores mais altos das classes arenosas grossas ocorrem especialmente nos 40 $\mathrm{cm}$ superiores, o que permite detectar dentro do intervalo um grosseiro padrão 
geral granocrescente, com aumento da assimetria e do desvio padrão (McLaren invertido). No exame de detalhe, entretanto, este padrão de Mc Laren invertido é mais evidente no intervalo de 65 a $35 \mathrm{~cm}$, notando-se, acima, restabelecimento do padrão McLaren de afinamento. Na mineralogia de pesados, atingem seus maiores valores nesta fácies superior: opacos, agregados argilo-limoníticos, alterita, zircão, turmalina e indice ZTR. Os valores elevados de componentes densos, como opacos e zircão, associados ao engrossamento da granulometria, ao padrão McLaren invertido e às maiores taxas de sedimentação (no intervalo de 80 a $10 \mathrm{~cm}$ ), indicam ganho de proximalidade progressivo, tanto em relação à fácies inferior como dentro do intervalo, pelo menos até $35 \mathrm{~cm}$ (cerca de 4800 anos A.P.). Os valores elevados de turmalina, resistato de densidade relativamente baixa, e de limonita e alterita, típicos produtos de alteração química em condições oxidantes, principalmente no topo do depósito (que é o mais exposto nos últimos 2000 anos e também o de taxa de sedimentação mais baixa), podem ser atribuídos ao efeito superimposto de ação intempérica.

A concentração total de palinomorfos aumenta significativamente com relação ao intervalo anterior e varia de 400 grãos por $\mathrm{cm}^{3}$, no caso de Araucaria na profundidade $90 \mathrm{~cm}$, até 10000 grãos por $\mathrm{cm}^{3}$, no caso de Eugenia, Matayba e Cordia, nas profundidades de $90 \mathrm{~cm}, 70 \mathrm{~cm}$ e $40 \mathrm{~cm}$, respectivamente.

O $\delta^{13} \mathrm{C}$ menos negativo (até $-18,53 \%$ ) entre 95 e $45 \mathrm{~cm}$ de profundidade (cerca de 17000 a 5300 anos A.P.), intervalo acompanhado de elevação progressiva, para cima, de $\mathrm{N}$ total e $\delta^{15} \mathrm{~N}$, e de queda da razão $\mathrm{C} / \mathrm{N}$, é indício de redução da influência da matéria orgânica de plantas terrestres, em detrimento de algas, talvez em momento de abertura relativa da cobertura florestal. No final deste intervalo, entre 65 e $35 \mathrm{~cm}$, a variação vertical da distribuição granulométrica exibe padrão de McLaren invertido, compatível com o aumento de influência da fonte esperado como decorrência da abertura da mata.

Nos $40 \mathrm{~cm}$ superiores da coluna sedimentar, equivalente aos últimos 5000 anos, o $\delta^{13} \mathrm{C}$ volta a cair, ainda que não a patamares tão baixos quanto antes de 17000 anos A.P., e a razão $\mathrm{C} / \mathrm{N}$ estabiliza-se. Este intervalo superior da coluna coincide com o maior aporte de areia do registro e com picos na concentração de Araucaria. Apesar do aumento da proporção de areia no intervalo acima de $40 \mathrm{~cm}$ como todo, a variação vertical das estatísticas de granulometria, ao longo deste 
intervalo, mostra padrão de McLaren de afinamento progressivo para cima, com aumento de pesados menos densos, o que sugere redução gradual da influência da fonte. Aparecem ainda, no mesmo intervalo, picos de Cordea e Tabebuia na profundidade de $45 \mathrm{~cm}$ inversos aos de Araucaria, indicativos de sucessão florestal. Isto sugere que o momento de abertura da mata iniciado cerca de 16000 A.P. culminou com o pico de aporte de areia por volta de 5000 anos e com esta sucessão florestal. Os últimos 5000 anos seriam de restabelecimento da cobertura florestal, possivelmente já nos moldes da existente hoje, e, portanto, de redução gradual do aporte de areia. 


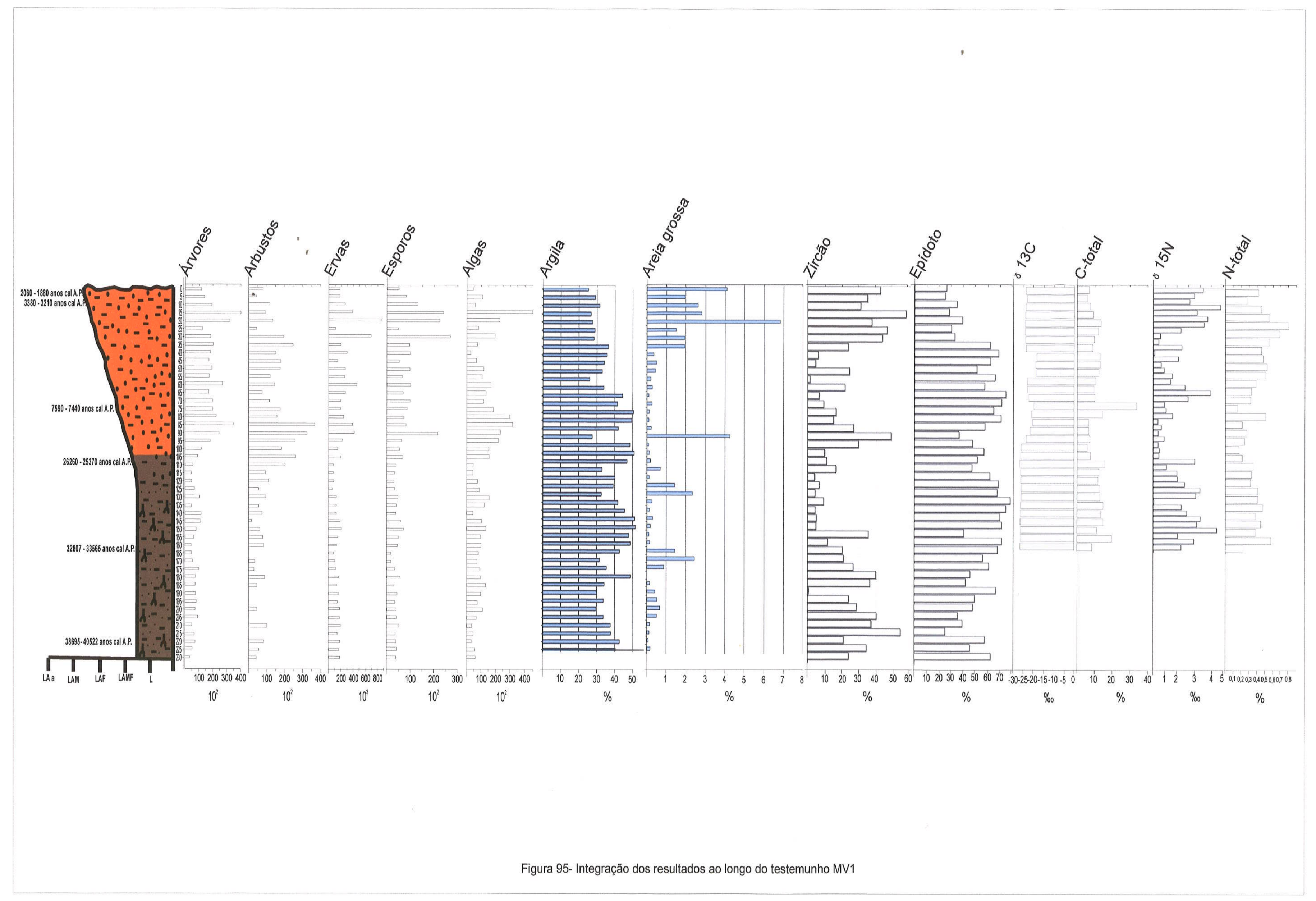


A análise integrada dos resultados do testemunho MV2 permitiu sua subdivisão em três intervalos principais: de 230 a $110 \mathrm{~cm}$ de profundidade, com idade compreendida entre 26023-26764 anos cal A.P. (obtida em $210 \mathrm{~cm}$ ) e mais de 20830-20370 anos cal A.P. (obtida na profundidade de $100 \mathrm{~cm}$ ); de 110 a 25 $\mathrm{cm}$; e acima de $25 \mathrm{~cm}$, correspondente ao periodo de 5977-5779 (idade extrapolada a partir de datação calibrada) a cerca de 2350-2150 anos cal A.P. (datação obtida em $10 \mathrm{~cm}$ ).

O primeiro intervalo, que termina pouco antes do UMG, abrange quatro fácies sedimentares: lama arenosa média a muito fina com raízes $(230-150 \mathrm{~cm})$, lama arenosa fina a muito fina rica em matéria orgânica coloidal $(150-130 \mathrm{~cm})$, areia muito fina a fina, lamosa, rica em matéria orgânica coloidal $(130-120 \mathrm{~cm})$ e lama arenosa fina a muito fina, compacta, rica em matéria orgânica coloidal (120$110 \mathrm{~cm})$.

A taxa de sedimentação deste intervalo inferior é a mais alta da coluna sedimentar, mas em padrão de variação declinante no tempo $(0,05 \mathrm{~cm} / a n o$ até $150 \mathrm{~cm}$, e $0,01 \mathrm{~cm} / a n o$, de 150 a $100 \mathrm{~cm}$ ). Análises granulométricas mostram que o intervalo possui também as maiores concentrações das classes areia muito grossa, areia grossa e areia média, em especial entre as profundidades 210 e 170 $\mathrm{cm} \mathrm{cm}$ (por volta de 26000 a 25000 anos AP). A sucessão, em maior parte deste intervalo, de dois ciclos de granodecrescência ascendente, com melhora de seleção e queda da assimetria na distribuição areia (padrão de McLaren) indica perda gradual da competência de transporte, com retenção seletiva de material mais grosso na fonte (distalidade crescente no tempo). Esta interpretação é coerente com a redução progressiva no tempo da taxa de sedimentação. $O$ indice ZE cai grosso modo para cima neste intervalo, indício adicional de seleção hidráulica crescente.

$\mathrm{O}$ intervalo concentra os menores teores de $\mathrm{C}$ e $\mathrm{N}$ totais da coluna, provavelmente ligados à diluição da matéria orgânica pelo aporte terrígeno elevado. Nele, encontram-se também as razões $\mathrm{C} / \mathrm{N}$ mais altas (em torno de 30 ), e os menores valores de $\delta^{13} \mathrm{C}$ e de $\delta^{15} \mathrm{~N}$. Resultados de $\delta^{13} \mathrm{C}$ variam de $-24,31 \%$ a $-26,85 \%$ indicativos de plantas $\mathrm{C} 3$, enquanto a concentração de $\delta^{15} \mathrm{~N}$ apresenta 
valores entre $2,07 \%$ e $4,17 \%$, sugestivos de predominio de fonte de matéria orgânica de origem terrestre.

As análises palinológicas mostraram que a concentração dos elementos arbóreos atinge em média 200 grãos por $\mathrm{cm}^{3}$, até $160 \mathrm{~cm}$ (cerca de 25000 anos A.P.), diminuindo gradativamente acima dessa profundidade, até chegar ao mínimo de 50 grãos por $\mathrm{cm}^{3}$, em $120 \mathrm{~cm}$ (cerca de 22000 anos A.P.). Acima desta profundidade, os valores mantêm-se baixos, até o topo do intervalo. Os arbustos possuem pico de 400 grãos por $\mathrm{cm}^{3}$ em $160 \mathrm{~cm}$, juntamente com as algas, que chegam a 300 grãos por $\mathrm{cm}^{3}$, mas depois desaparecem. A presença contínua de Araucaria e de elementos arbóreos acessórios deste ecossistema indicam que não houve ruptura na distribuição desses táxons neste período imediatamente anterior ao UMG, que, na localidade de estudo, seria caracterizado por cobertura vegetal densa. A parte superior do intervalo $(130 \mathrm{a} 110 \mathrm{~cm}$ ) é marcada ainda por depósito de fluxo de detritos, no topo do qual se associa o desaparecimento pontual das algas dos gêneros Debarya e Zygnema entre 135 e $130 \mathrm{~cm}$.

O segundo intervalo, de 110 a $25 \mathrm{~cm}$, possui idades de $20830-20370$ anos cal A.P. (idade obtida na profundidade de $100 \mathrm{~cm}$ ) a $5977-5779$ (idade extrapolada) e engloba, portanto, desde a iminência do UMG até o Médio Holoceno. Sua base marca mudança abrupta de área fonte, passando do franco domínio de fonte granitica próxima para a mistura de influência dessa fonte próxima com a de terreno metamórfico mais distante, o que é evidenciado pela granulometria mais fina e pelo incremento brusco da assembleia mineralógica regionalmente associada a gnaisses (zircão, sillimanita e titanita), em detrimento da assembleia atribuída a granitos (epídoto, hornblenda e turmalina). Ao longo do intervalo, as análises granulométricas indicam engrossamento da fração areia para cima, acompanhado de melhora de seleção e tendência para assimetria mais positiva, padrão sugestivo de distalidade ou retrabalhamento progressivo, porém com aumento de competência. O aumento gradual de minerais pesados menos densos (epidoto) para cima, em detrimento dos mais densos (zircão, titanita), é incompativel com o engrossamento do ponto de vista da seleção hidráulica. Mas é compatível com ele do ponto de vista da área fonte, isto é, retomada gradual da importância das fontes proximais graníticas. As taxas de 
sedimentação mais altas na parte superior do intervalo (acima de $70 \mathrm{~cm}$ ) são também coerentes com a ideia de aumento da influência destas fontes proximais.

Quanto aos resultados geoquímico-isotópicos, o intervalo caracteriza-se por valores mais altos de $\mathrm{C}$ total, $\mathrm{N}$ total, $\delta^{13} \mathrm{C}$ e $\delta^{15} \mathrm{~N}$, em comparação com o intervalo anterior, e por valores mais baixos de $\mathrm{C} / \mathrm{N}$. Este conjunto de mudanças permite interpretar elevação do aporte e/ou preservação de matéria orgânica e incremento na influência de algas. Assim, diferentemente do observado em MV1, o aumento da taxa de sedimentação e de componentes grossos estaria ligado à chegada e manutenção de matéria orgânica, o que sugere soterramento rápido, em condições pouco oxidantes, de material nela previamente enriquecido. Esta condição seria favorecida pelo incremento gradual da influência de fontes próximas, via dinâmica fluvial e/ou fluxos de encostas. Os resultados de razäo isotópica $\delta^{13} \mathrm{C}$ variam de um mínimo de $-26,9 \%$ a um máximo de $-18,6 \%$, valores sugestivos de manutenção do predomínio de plantas $\mathrm{C} 3$, porém possivelmente com vegetação mais aberta, especialmente acima de $85 \mathrm{~cm}$ (mais novo que crerca de 17000 anos $\mathrm{AP}$ ), onde os valores de $\delta^{13} \mathrm{C}$ e $\delta^{15} \mathrm{~N}$ são comparativamente mais altos. $O \delta^{15} \mathrm{~N}$ apresenta ainda aumento ascendente bem evidenciado ao longo do intervalo, variando de 2,8\% a 6,6 \%. Esta ordem de grandeza de valores é compatível com a continuidade da fonte de matéria orgânica de origem terrestre, porém, com aumento gradual da influência de algas e portanto de umidade, hipótese reforçada pela redução gradual da razão $\mathrm{C} / \mathrm{N}$, para cima.

A maior concentração de elementos arbóreos neste intervalo, em relação ao anterior, é bem representada pelo gênero Cordia, que atinge cerca de 4000 grãos por $\mathrm{cm}^{3}$. Araucaria sofre oscilações em todo intervalo, com concentração média por volta de 250 grãos por $\mathrm{cm}^{3}$. A partir de $85 \mathrm{~cm}$ (cerca de 17000 anos A.P.), ocorre um declínio gradual de Araucaria, Miconia, Myrsine, Podocarpus, Prunus e Weinmania, a qual desaparece. Em paralelo, inicia-se aumento gradativo de Cordia, Euterpe, Ilex, Lauraceae e outros elementos, que são encontrados na floresta moderna local.

Essa mudança iniciada por volta de $85 \mathrm{~cm}$, associada à elevação da taxa de sedimentação e ao aumento na concentração das algas indicado pelos valores de $\delta^{15} \mathrm{~N}$, pode refletir uma sucessão da cobertura florestal de encosta, com possivel aumento de umidade e/ou alagamento no sítio deposicional. O padrão de 
McLaren com engrossamento, verificado acima de $110 \mathrm{~cm}$, é compativel com deposição cada vez mais influenciada por fontes proximais rumo aos vales fluviais, inclusive fluxos de encosta, o que favoreceria aumento da formação e/ou preservação de matéria orgânica, manifestada na elevação dos teores de $\mathrm{C}$ e $\mathrm{N}$.

O último intervalo corresponde aos $25 \mathrm{~cm}$ superiores, com idade extrapolada mais nova que cerca de 6000 anos A.P.. Caracteriza-se por melhor seleção granulométrica da fração areia (desvio padrão menor que 2). $E m 15 \mathrm{~cm}$ (cerca de 3500 anos A.P.), evidencia-se um pico de engrossamento, com baixa maturidade textural e mineralógica, esta indicada pelo aumento na concentração de minerais pesados instáveis e metaestáveis, inclusive alteritas. Minerais transparentes atribuídos às fontes graníticas locais, como epidoto, hornblenda $\mathrm{e}$ turmalina, caem ou mantêm a proporção neste intervalo, enquanto titanita e sillimanita, atribuídos às fontes metamórficas distais, aumentam.

Araucaria apresenta neste intervalo seu máximo de concentração em toda coluna com cerca de 450 grãos por $\mathrm{cm}^{3}$ na profundidade de $20 \mathrm{~cm}$, acompanhado pelo aumento significativo de Anacardium, Bignoniaceae, Connarus, Eugenia, llex, Podocarpus, entre outros.

$\mathrm{C}$ e $\mathrm{N}$ totais caem, indicando redução do aporte ou preservação de matéria orgânica, possivelmente por diluição terrígena. Os resultados de $\delta^{13} \mathrm{C}$ são também em média ligeiramente mais baixos que no intervalo anterior $e$ apresentam declínio para cima, variando entre um máximo de $-19,8 \%$, na base, a um mínimo de $-23,8 \%$, no topo. Esses valores são compatíveis com manutenção do predomínio de plantas $\mathrm{C} 3$. Por outro lado, o $\delta^{15} \mathrm{~N}$ atinge os valores mais elevados da coluna, entre $7,0 \%$ e $7,8 \%$, o que pode ser interpretado como incremento na participação de matéria orgânica associada a algas e, portanto, da umidade. Esta interpretação é apoiada pelo aumento na representatividade das algas Debarya e Zygnema, as quais atingem concentrações de 350 e 1500 grãos por $\mathrm{cm}^{3}$, respectivamente, bem como de ervas aquáticas.

A integração dos resultados permite assim inferir um aumento do aporte terrígeno neste último intervalo, aparentemente ligado à própria dinâmica fluvial, sob presença de vegetação pouco diversa da atual. Embora as mudanças sedimentológicas sejam acompanhadas de evidências palinológicas de máximo desenvolvimento de elementos arbóreos na região, a grande quantidade de algas, 
associada à elevação de $\delta^{15} \mathrm{~N}$ a valores acima de $7,0 \%$, favorece a ideia de aumento do nivel de água e manutenção de brejos, presumivelmente associados a inundações na planície fluvial. Dessa forma, o registro seria de fase com maior frequência e/ou intensidade de inundações nos vales. 


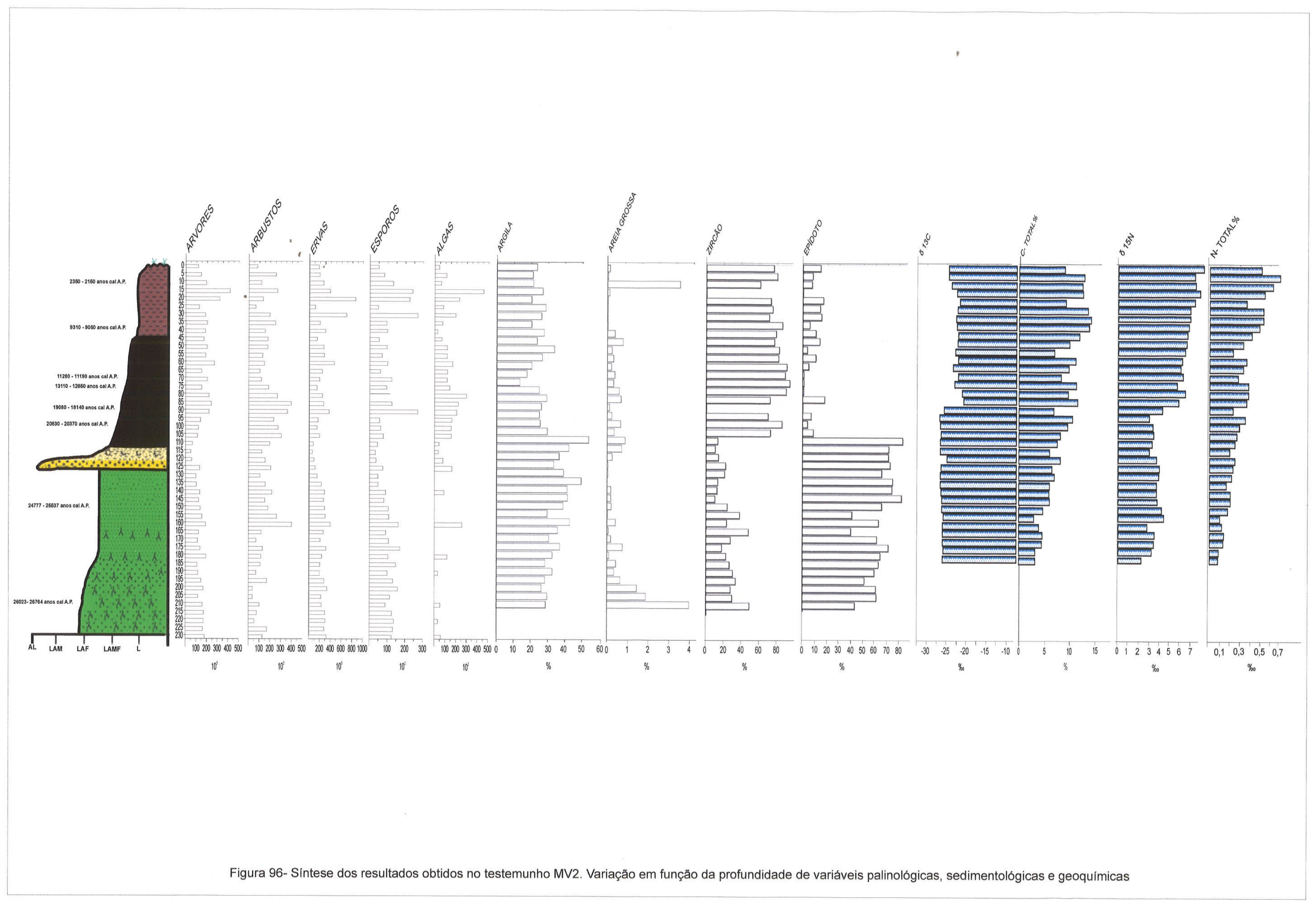


De acordo com o conjunto de resultados apresentados, é possivel inferir que o periodo equivalente ao UMG, em Monte Verde, registra a presença de pólen típico da Floresta de Araucária, tais como Araucaria, Drymis, llex e Podocarpus. Esses elementos são característicos de áreas com altitudes acima de $1500 \mathrm{~m}$, adaptados a condições climáticas frias e úmidas, conforme já encontrado, para essa mesma época, em outras áreas serranas do Sudeste do Brasil (De Oliveira, 1992; Ledru, 1993, Melhem et al., 2003).

Resultados sugestivos de vegetação fisionomicamente mais fechada de que a atual floresta de gimnospermas, com a presença de Araucária, Alchornea, Podocarpus, llex e Palmeiras, por exemplo, convergem para a interpretação de clima mais frio e úmido que o presente no início do UMG, atribuído por Ledru (1993) à intensificação das massas de ar de origem polar nas áreas montanhosas da Região Sudeste.

Climas mais frios e úmidos do que o atual durante o UMG já foram inferidos também em várias outras regiões do país. Em Volta Velha (SC), no intervalo de ca. 27500 a ca. 14500 anos A.P., Behling \& Negrelle (2001) interpretaram a ocorrência freqüente de Myrtaceae e Melastomataceae e, mais raramente, de Podocarpus, Symplocos e llex, como evidências de florestas tropicais adaptadas a clima frio, ainda que sem a presença de Araucaria angustifolia. Similarmente, e ainda no Estado de Santa Catarina, Cruz (2003) aponta para clima frio e úmido durante o UMG, baseado no estudo de razões isotópicas de $\delta^{18} \mathrm{O} \mathrm{em}$ espelotemas da caverna de Botuverá. Na região de Lagoa dos Olhos (MG), De Oliveira (1992) reconstitui a vegetação do período de 19950 a 15360 anos A.P. como um mosaico floresta-savana com a presença de Podocarpus. E, em Lagoa Bonita (DF), Barberi (2001) baseia sua interpretação de clima frio e úmido durante o período entre 26000 e 19700 anos A.P. (idades extrapoladas) na ocorrência de grande quantidade de elementos arbóreos como llex, Hedyosmum e Podocarpus. Em contraposição, Ledru (1993) e Behling (2001) defendem que nos cerrados do Planalto Central do Brasil esse mesmo período teria sido dominado por uma estação mais seca que a atual e com temperaturas em torno de 10 a $15^{\circ} \mathrm{C}$. 
Para Kerry (2009), os dados de proxies geológicos deixam claro que o clima na América do Sul foi diferente durante o UMG. A figura 97 resume as informações sobre as distribuições de temperatura e precipitação na América do Sul durante o UMG, reconstruidas a partir de pólen, espeleotemas e microfósseis, dentre outros indicadores.

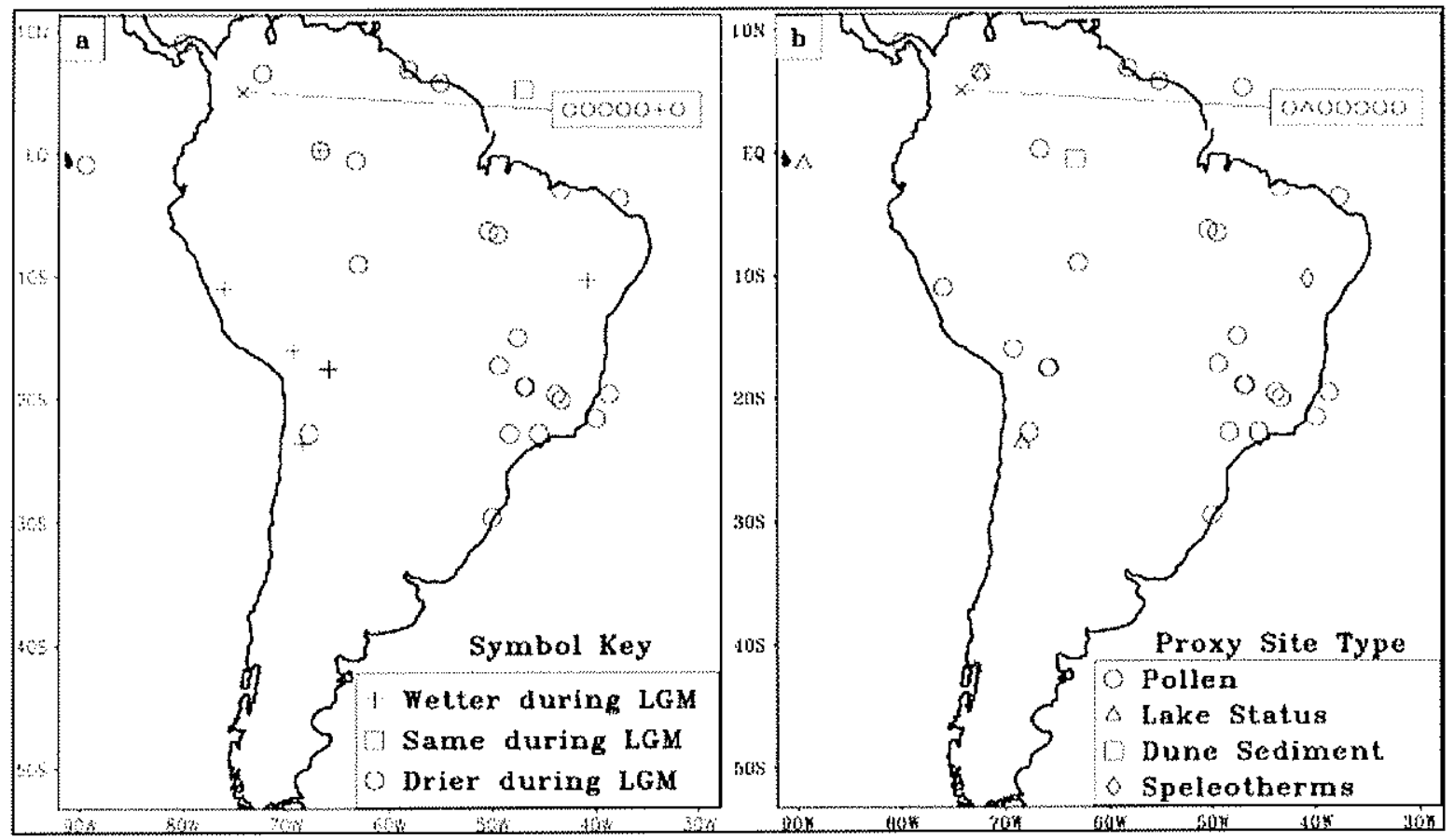

Figura 97- Sintese dos resultados obtidos para o UMG na América do Sul (a) e fontes de informação utilizadas para as reconstruções climáticas (b). Fonte: Kerry (2009).

Divergências de interpretações paleoclimáticas entre diferentes estudos paleoambientais envolvendo o UMG no Brasil podem ser interpretadas como decorrentes da compartimentação do território, quanto ao clima, pela distribuição da ZCAS, faixa de máxima nebulosidade e umidade. Como mostra a Figura 98, ao sul desta faixa o clima menos úmido é explicado pela prevalecência da massa de ar polar seca e fria enquanto que ao norte dela, o clima mais quente e seco é controlado pelas massas de ar geradas pelo sistema anticiclônico móvel do Atlântico Sul. 


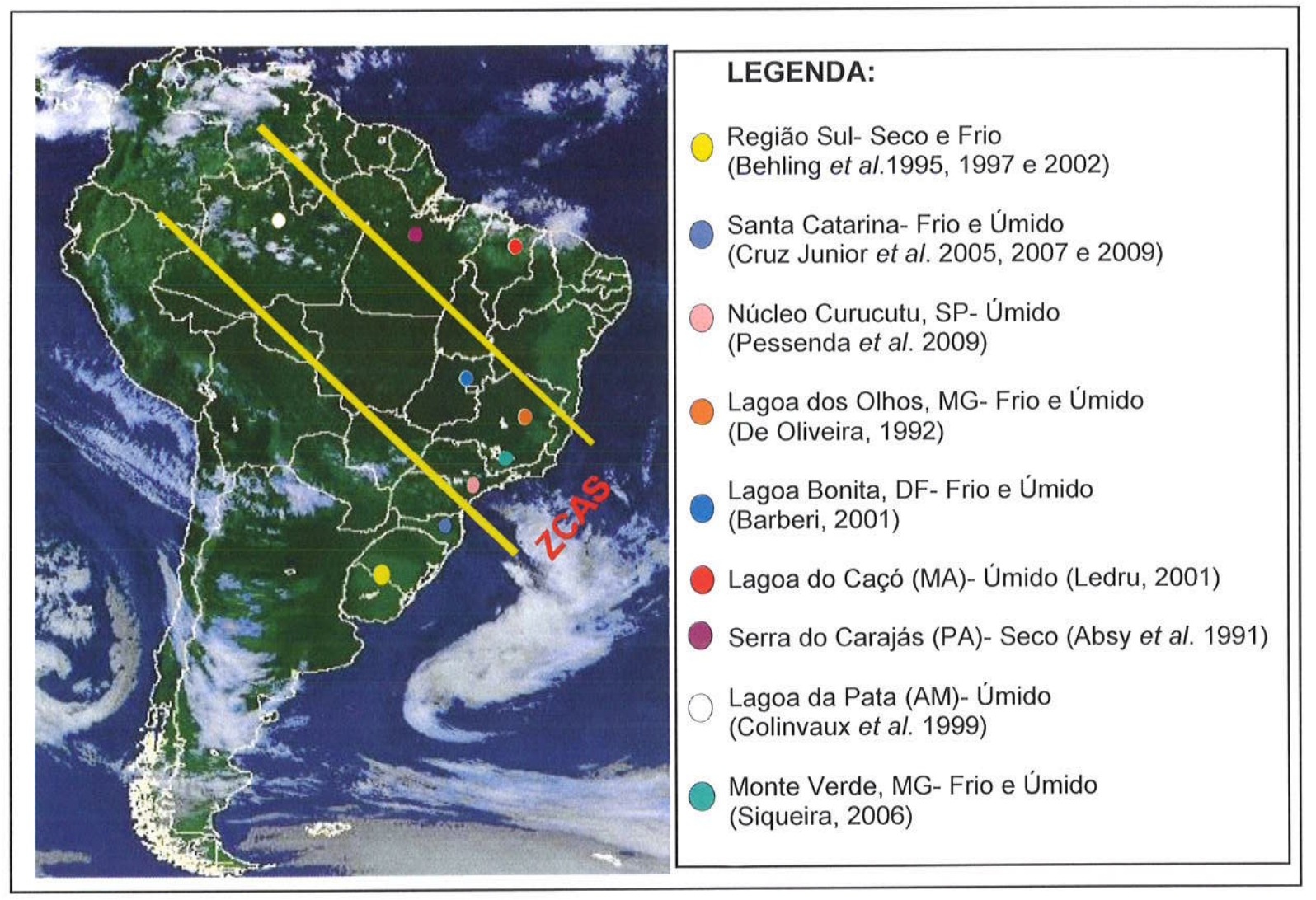

Figura 98- Clima do Último Máximo Glacial (UMG) interpretado por estudos paleoambientais em diferentes regiões do Brasil e sua possível relação com o posicionamento geográfico da ZCAS.

\section{- Sucessão ecológica}

No intervalo entre cerca de 17000 e 6000 a 5000 anos cal. A.P. (idades extrapoladas a partir de datações calibradas), observa-se nos dados de Monte Verde aqui obtidos um declínio de Araucaria e de outros elementos associados como Melastomataceae, Myrtaceae, Podocarpus, Symplocos e Weinmania, a qual chega a desaparecer nos dois testemunhos. Estas mudanças na composição florística podem ser explicadas pelo modelo aventado por Klein (1975), segundo o qual a floresta clímax de Araucaria possui composições florísticas diferentes, de acordo com o estágio de desenvolvimento em que se encontra. Esse fenômeno ecológico sucessional pode estar representado em Monte Verde pelo aumento de Drymis, Tabebuia e Cordia, além de outros elementos que são encontrados na floresta moderna local. 
Nos últimos 6000 a 5000 anos A.P., as condições de clima frio e úmido são reintensificadas com o aumento expressivo de Araucaria, Drymis, Ilex, Symplocos e Podocarpus. Este cenário climático hipotético é corroborado pelos estudos de Garcia et al. (2004), que registraram aumento de umidade e condições mais frias que as atuais no médio Holoceno, por volta de 3500 anos A.P., na região do vale do Paraíba, no Estado de São Paulo. Esta fase foi favorecida nessa região pelo aparecimento de elementos como Ilex, Podocarpus, Daphnopsis, Gaylussacia e Leucothoe.

Outra característica que merece ser discutida para a região de Monte Verde é o fato de a família Poaceae ser representada principalmente por Bambusaceae (bambus), presente na mata fechada primária de Araucaria. Esses dados concordam com Colinvaux et al. (1999) e Bush (2002), que afirmam que muitos estágios de sucessão florestal são caracterizados pela presença de bambus, excelentes produtores de um sinal polinico que pode erroneamente ser interpretado como vegetação de clima seco e árido.

\section{- Correlações entre MV1 e MV2}

As características observadas nos testemunhos MV1 e MV2 foram correlacionadas no tempo (Quadros 2 e 3) e suas interpretações permitiram a subdivisão da evolução sedimentar em dois intervalos maiores (Quadro 4).

No primeiro intervalo, correspondente ao período aproximado de 40500 a 26000/21500 anos cal A.P., a sedimentação na planície de inundação fluvial experimentou redução progressiva da taxa de sedimentação, possivelmente relacionada a distanciamento crescente da fonte sedimentar.

Neste cenário deposicional, o aporte de matéria orgânica provinha provavelmente de matas ciliares a montante e encostas, onde a vegetação terrestre era densa, com forte contribuição de plantas $\mathrm{C} 3$, incluindo elementos de Floresta de Araucária. A associação palinológica aponta assim para condições frias e úmidas.

Entre 26000 e 21500 anos A.P., mudanças acentuadas de faciologia ocorrem em ambas as colunas sedimentares estudadas. Ainda que estas mudanças representem respostas sedimentológicas diferentes a montante (MV1), 
onde ela marca o início de um ciclo de engrossamento, e a jusante (MV2), onde começa a deposição de sedimentos mais finos, a sua coincidência aproximada no tempo torna possível interpretar uma alteração de caráter regional no sistema deposicional aluvial de alvéolo serrano. Além disso, em ambas as colunas, os indícios sedimentológicos são de aumento de proximalidade em relação à área fonte, ao longo do intervalo. A importância das algas, balizada pelos valores de $\delta^{15} \mathrm{~N}$ e pela concentração de Debarya e Zygnema, aumenta em grande parte do intervalo, sobretudo após 17000 anos A.P., atingindo seu pico entre 5000 e 3500 anos A.P.. Esse periodo que vai de aproximadamente 17000 anos A.P. ao meio do Holoceno talvez seja representativo de um aumento das inundações no vale fluvial e da umidade no sítio deposicional. Ele é acompanhado por ligeiro declínio de Araucária, interpretado como abertura da floresta em fase de sucessão vegetacional. Também em ambas as colunas, nota-se incremento pronunciado no suprimento de terrígenos e de grossos na porção de topo, correspondente aos últimos 5000 a 6000 anos, com auge entre 5000 e 3500 anos A.P. Este aumento do aporte terrígeno a partir do meio do Holoceno é detectado ainda na análise geoquímica e isotópica. O mesmo periodo inclui o aumento na concentração de palinomorfos de clima frio, o que sugere o readensamento da Floresta de Araucária dentro desse intervalo de tempo.

Esses dados permitiram a reconstrução da vegetação local nos últimos 40 mil anos (Figura 99). 


\begin{tabular}{|c|c|c|c|c|}
\hline $\begin{array}{c}\text { INTERVALOS } \\
\text { MV1 }\end{array}$ & SEDIMENTOLOGIA & PALINOLOGIA & $\begin{array}{l}\text { GEOQUIIMICAE } \\
\text { ISÓTOPOS }\end{array}$ & INTERPRETAÇÃO \\
\hline \multirow{3}{*}{$\begin{array}{l}230 \text { a } 110 \mathrm{~cm} \\
\text { Fácies lama arenosa } \\
\text { muito fina a média } \\
\text { com fragmentos de } \\
\text { raizes } \\
\text { DATAÇÃO } \\
40522-38695 \text { a } \\
26260-25370 \\
\text { anos cal A.P. }\end{array}$} & \multirow{3}{*}{$\begin{array}{l}\checkmark \text { Maior concentração de areia fina, } \\
\text { areia muito fina e argila } \\
\checkmark \text { Desvio padrão mais baixo } \\
\checkmark \text { Assimetria mais positiva } \\
\checkmark \text { Maiores proporções de titanita e } \\
\text { hornblenda } \\
\checkmark \text { indice TH mais alto } \\
\checkmark \text { Dois ciclos de padrão McLaren } \\
\text { acima de } 200 \mathrm{~cm} \text {, com afinamento } \\
\text { ascendente e redução de minerais } \\
\text { pesados densos }\end{array}$} & \multirow{3}{*}{$\begin{array}{l}\checkmark \text { Baixa concentração de } \\
\text { palinomorfos } \\
\checkmark \text { Material pouco preservado } \\
\checkmark \text { Predominio de elementos } \\
\text { arbóreos } \\
\checkmark \text { Estabilidade de Araucaria em } \\
\text { torno de } 100 \mathrm{~g} / \mathrm{cm}^{3} \\
\checkmark \text { Presença significativa de } \\
\text { Podocarpus, Ilex, Drymis, } \\
\text { Myrsine, Symplocos e Mytaceae }\end{array}$} & \multirow{3}{*}{$\begin{array}{l}\checkmark / N \text { acima de } \\
30 \% \text { e } \\
\checkmark \quad \text { e } N \text { em } \\
\text { padrão } \text { de } \\
\text { variação } \\
\text { declinante no } \\
\text { tempo } \\
\checkmark \delta^{15} \mathrm{~N} \text { abaixo de } \\
4 \% \circ \\
\checkmark \delta^{13} \mathrm{C} \text { menor que } \\
-24 \%\end{array}$} & $\begin{array}{l}\text { Sedimentologia } \\
\text {-Sedimentação lenta, de baixa energia, com } \\
\text { exposição ao intemperismo } \\
\text { - Contexto de planicie de inundação fluvial } \\
\text { distal } \\
\text { - Distanciamento progressivo da fonte } \\
\text { sedimentar }\end{array}$ \\
\hline & & & & $\begin{array}{l}\text { Palinologia } \\
\text { - Pouca presenvação dos palinomorfos } \\
\text { (atuação do intemperismo) } \\
\text { - Floresta fechada } \\
\text { - Condições frias e úmidas }\end{array}$ \\
\hline & & & & $\begin{array}{l}\text { Geoquímica e isótopos } \\
\text { - Fonte de matéria orgânica terrestre } \\
\text { - Contribuição de plantas C3 }\end{array}$ \\
\hline \multirow{3}{*}{$\begin{array}{l}\text { Acima de } \\
110 \mathrm{~cm} \\
\text { Fácies lama arenosa } \\
\text { muito fina a grossa } \\
\text { DATAÇÃo } \\
\text { 26000 a } 2000 \\
\text { anos cal A.P. }\end{array}$} & \multirow{3}{*}{$\begin{array}{l}\checkmark \text { Máxima taxa de sedimentação da } \\
\text { coluna (80 a } 10 \mathrm{~cm} \text { ) } \\
\checkmark \text { Maior concentração de areia } \\
\text { grossa a muito grossa } \\
\checkmark \text { Padrão grosseiro de } \\
\text { granocresência para cima, com } \\
\text { aumento da assimetria e de desvio } \\
\text { padrão (McLaren invertido = } \\
\text { proximalidade crescente) } \\
\checkmark \text { Alta concentração de opacos, } \\
\text { agregados limoniticos, alterita, } \\
\text { zircão, turmalina e ZTR } \\
\checkmark \text { Concentração de produtos de } \\
\text { alteração no topo ( } 40 \mathrm{~cm} \text { ) }\end{array}$} & \multirow{3}{*}{$\begin{array}{l}\checkmark \text { Aumento na concentração de } \\
\text { palinomorfos } \\
\checkmark \text { Presença significativa de } \\
\text { Araucana, Eugenia, Matayba e } \\
\text { Cordia } \\
\checkmark \text { Boa representação de ervas } \\
\text { aquáticas e algas }\end{array}$} & \multirow{3}{*}{$\begin{array}{ll}\checkmark & \delta^{13} \mathrm{C} \text { menos } \\
& \text { negativo } \\
\checkmark & \text { Razão } \mathrm{C} / \mathrm{N} \\
& \text { declinante } \\
\checkmark & \mathrm{N}_{\text {total }} \mathrm{e} \delta^{15} \mathrm{~N} \\
\text { grosso modo } \\
\text { crescentes }\end{array}$} & $\begin{array}{l}\text { Sedimentologia } \\
\text { - Ganho de proximalidade progressivo } \\
\text { - Efeito de ação intempérica no topo (últimos } \\
5000 \text { anos) } \\
\text { - Maior aporte de areia na porção superior } \\
\text { (últimos } 5000 \text { anos) }\end{array}$ \\
\hline & & & & $\begin{array}{l}\text { Palinologia } \\
\text { - Aumento na concentração de palinomorfos } \\
\text { - Ligeira abertura florestal com sucessão } \\
\text { vegetacional a partir de } 17000 \mathrm{AP} \\
\text { - Posterior readensamento nos últimos } 5000 \\
\text { anos }\end{array}$ \\
\hline & & & & $\begin{array}{l}\text { Geoquímica e isótopos } \\
\text { - Aumento da influência de matéria orgânica } \\
\text { de algas, em detrimento de plantas terrestres. }\end{array}$ \\
\hline
\end{tabular}




\begin{tabular}{|c|c|c|c|c|}
\hline $\begin{array}{c}\text { INTERVALOS } \\
\text { MV2 } \\
\end{array}$ & SEDIMENTOLOGIA & PALINOLOGIA & $\begin{array}{l}\text { GEOQUIMICAE } \\
\text { ISÓTOPOS }\end{array}$ & INTERPRETAÇÃOO \\
\hline $\begin{array}{c}230 \text { a } 110 \mathrm{~cm} \\
\text { Fácies lama arenosa } \\
\text { média a muito fina com } \\
\text { raizes (até } 150 \mathrm{~cm} \text { ); lama } \\
\text { arenosa fina a muito fina } \\
\text { rica em matéria orgânica }\end{array}$ & \multirow{3}{*}{ 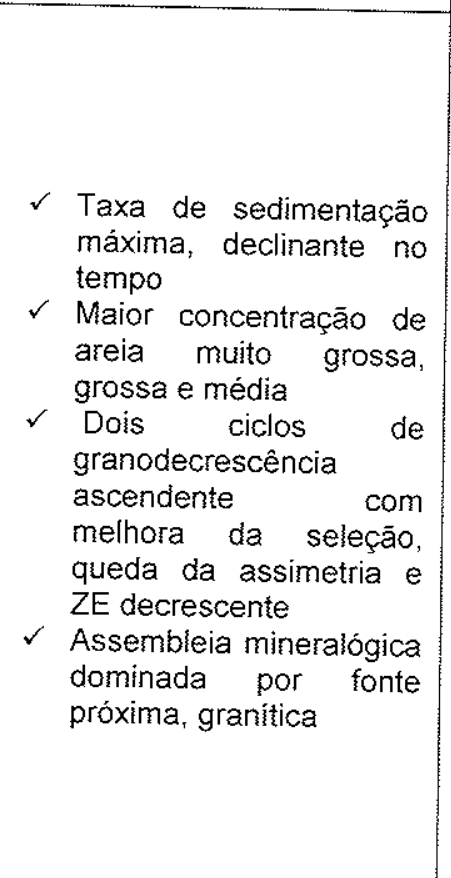 } & \multirow{3}{*}{$\begin{array}{l}\checkmark \text { Concentração média de } \\
200 \mathrm{~g} / \mathrm{cm}^{3} \\
\checkmark \text { Queda gradativa de } \\
\text { concentração para cima } \\
\text { Presença contínua de } \\
\text { Araucaria }\end{array}$} & \multirow{3}{*}{ 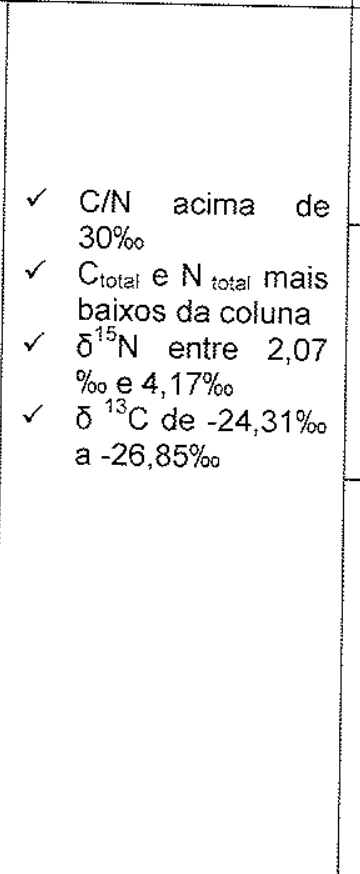 } & $\begin{array}{l}\text { Sedimentologia } \\
\text { - Dois ciclos de distalidade crescente } \\
\text { - Planície de inundação fluvial com fonte próxima } \\
\text { - Fluxo de detritos coesivo no final do intervalo }\end{array}$ \\
\hline $\begin{array}{c}\text { coloidal (até } 130 \mathrm{~cm} \text { ); } \\
\text { areia fina a muito fina, } \\
\text { lamosa, rica em matéria } \\
\text { orgânica coloidal (até } 125 \\
\mathrm{~cm} \text { ); lama arenosa fina a } \\
\text { muito fina rica em matéria } \\
\text { orgânica coloidal (até } 120\end{array}$ & & & & $\begin{array}{l}\text { Palinologia } \\
\text { - Cobertura vegetail densa } \\
\text { - Momento de abertura florestal e aumento da } \\
\text { umidade em } 160 \mathrm{~cm} \text { e/ou sucessão florestal } \\
\text { - Condições frias e úmidas }\end{array}$ \\
\hline $\begin{array}{l}\mathrm{cm} \text { ) e lama arenosa fina a } \\
\text { muito fina compacta, rica } \\
\text { em matéria orgânica } \\
\text { coloidal e particulada (até } \\
110 \mathrm{~cm} \text { ) } \\
\text { DATAÇÃo } \\
26023-26764 \text { a } \\
20830-20370 \\
\text { anos cal A.P. }\end{array}$ & & & & $\begin{array}{l}\text { Geoquímica e isótopos } \\
\text { - Diluição de matéria orgânica pelo aporte terrígeno } \\
\text { intenso } \\
\text { - Franco dominio de plantas C3 e matéria orgânica } \\
\text { terrestre }\end{array}$ \\
\hline \multirow{3}{*}{$\begin{array}{c}110 \text { a } 25 \mathrm{~cm} \\
\text { Fácies lama arenosa fina } \\
\text { a muito fina compacta até } \\
45 \mathrm{~cm} \text { seguida de lama } \\
\text { arenosa, porosa, aerada } \\
\text { DATAÇÃO } \\
20830-20370 \text { a } \\
5977-5779 \\
\text { anos cal A.P. }\end{array}$} & \multirow{3}{*}{$\begin{array}{l}\checkmark \text { Granulometria mais fina } \\
\checkmark \text { Engrossamento } \\
\text { ascendente da fração } \\
\text { areia, com melhora da } \\
\text { seleção e assimetria } \\
\text { mais positiva } \\
\checkmark \text { Assembleia mineralógica } \\
\text { de fonte distante, } \\
\text { gnáissica, e próxima, } \\
\text { granitica }\end{array}$} & \multirow{3}{*}{$\begin{array}{l}\checkmark \text { Maior concentração de } \\
\text { elementos arbóreos } \\
\checkmark \text { Oscilação da Araucaria, } \\
\text { com declinio após } 17000 \\
\text { anos AP } \\
\checkmark \text { Maior presença neste } \\
\text { intervalo dos elementos } \\
\text { presentes na fioresta } \\
\text { moderna local }\end{array}$} & \multirow{3}{*}{ 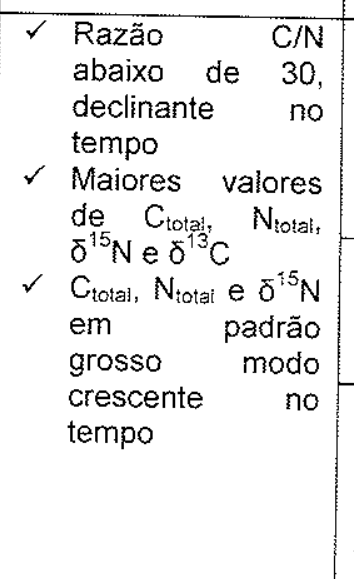 } & $\begin{array}{l}\text { Sedimentologia } \\
\text { - Estabelecimento da influência de fonte gnáissica, } \\
\text { distal, porém declinante no tempo } \\
\text { - Aumento de competência ligado a aumento gradual } \\
\text { de fonte próxima, granítica }\end{array}$ \\
\hline & & & & $\begin{array}{l}\text { Palinologia } \\
\text { - Sucessão florestal de encosta } \\
\text { - Clima frio e úmido }\end{array}$ \\
\hline & & & & $\begin{array}{l}\text { Geoquímica e isótopos } \\
\text { - Elevação do aporte elou preservação da matéria } \\
\text { orgânica } \\
\text { - Contribuição de plantas } \mathrm{C} 3 \\
\text { - Incremento na influência de algas }\end{array}$ \\
\hline
\end{tabular}




\begin{tabular}{|c|c|c|c|c|}
\hline $\begin{array}{l}\text { Acima de } 25 \mathrm{~cm} \\
\text { Fácies lama arenosa, } \\
\text { porosa, aerada rica em } \\
\text { matéria orgânica coloidal } \\
\text { DATAÇÃo }\end{array}$ & $\begin{array}{l}\checkmark \text { Melhor seleção } \\
\text { granulométrica } \\
\checkmark \text { Aumento pontual de } \\
\text { minerais atribuídos às } \\
\text { fontes gnáissicas (15 } \\
\mathrm{cm})\end{array}$ & $\begin{array}{l}\checkmark \text { Máximo concentração de } \\
\text { Araucaria (500 } \mathrm{g} / \mathrm{cm}^{3}, \\
\text { em } 15 \mathrm{~cm}) \\
\text { Aumento } \\
\text { Anacardium, } \\
\text { Bignoniaceae, } \\
\text { Connarus, Eugenia, Ilex }\end{array}$ & $\begin{array}{l}\checkmark \text { Razāo de } \mathrm{C} / \mathrm{N} \\
\text { abaixo de } 26, \\
\text { declinante } \\
\mathrm{C}_{\text {total } \mathrm{N}} \mathrm{N} \text { total } \\
\text { voltam a cair } \\
\checkmark \mathrm{O}^{15} \mathrm{~N} \text { acima de } \\
7 \% \text {, crescente }\end{array}$ & $\begin{array}{l}\text { Sedimentologia - Aumento do aporte terrigeno } \\
\text { ligado à dinâmica fluvial } \\
\text { Palinologia } \\
\text { - Aumento da umidade } \\
\text { - Clima frio e umido } \\
\text { - Readensamento da Floresta de Araucária, com pico } \\
\text { em } 3500 \text { anos AP }\end{array}$ \\
\hline $\begin{array}{c}\text { Últimos } \\
6000 \\
\text { anos cal A.P. }\end{array}$ & & $\begin{array}{l}\text { e Podocarpus } \\
\text { Pico na concentração de } \\
\text { algas (15 cm) }\end{array}$ & $\checkmark \delta{ }^{13} \mathrm{C}$ declinante & $\begin{array}{l}\text { Geoquímica e isótopos } \\
\text { - Redução do aporte ou preservação de matéria } \\
\text { orgânica por diluição terrigena } \\
\text { - Manutenção de plantas C3 } \\
\text { - Aumento de matéria orgânica associada a algas, } \\
\text { com pico em } 3500 \text { anos AP }\end{array}$ \\
\hline
\end{tabular}




\begin{tabular}{|c|c|c|}
\hline INTERVALO & INTERPRETAÇÓES MV1 & INTERPRETAÇŐES MV2 \\
\hline \multirow{3}{*}{ 40522- 23000 anos A.P. } & $\begin{array}{l}\text { Sedimentologia } \\
\text {-Sedimentação lenta, baixa energia e exposição ao } \\
\text { intemperismo; } \\
\text { - Contexto de planície de inundação fluvial distal; } \\
\text { - Distanciamento progressivo da fonte sedimentar. }\end{array}$ & $\begin{array}{l}\text { Sedimentologia } \\
\text {-Perda gradual na competência do transporte } \\
\text { - Retenção seletiva de material mais grosso na fonte } \\
\text { - Redução progressiva na taxa de sedimentação } \\
\text { - Seleção hidráulica crescente } \\
\text { - Planicie de Inundação fluvial }\end{array}$ \\
\hline & $\begin{array}{l}\text { Palinologia } \\
\text { - Pouca preservação dos palinomorfos (atuação do } \\
\text { intemperismo) } \\
\text { - Floresta fechada } \\
\text { - Condições frias e úmidas }\end{array}$ & $\begin{array}{l}\text { Palinologia } \\
\text { - Cobertura vegetal densa } \\
\text { - Momento de abertura florestal e aumento da } \\
\text { umidade em } 160 \mathrm{~cm} \text { e/ou sucessão florestal } \\
\text { - Condições frias e úmidas }\end{array}$ \\
\hline & $\begin{array}{l}\text { Geoquímica e isótopos } \\
\text { - Fonte de matéria orgânica terrestre } \\
\text { - Contribuição de plantas C3 }\end{array}$ & $\begin{array}{l}\text { Geoquimica e isótopos } \\
\text { - Diluição de matéria orgânica pelo aporte terrígeno } \\
\text { - Contribuição de plantas C3 } \\
\text { - Predominio de matéria orgânica terrestre }\end{array}$ \\
\hline \multirow{3}{*}{ Últimos 23000 anos A.P. } & $\begin{array}{l}\text { Sedimentologia } \\
\text { - Ganho de proximalidade progressivo } \\
\text { - Efeito de ação intempérica } \\
\text { - Maior aporte de areia na porção superior }(40 \mathrm{~cm}) \\
\text { - Padrão McLaren de afinamento progressivo } \\
\text { - Redução gradual da área fonte }\end{array}$ & $\begin{array}{l}\text { Sedimentologia } \\
\text { - Area fonte granitica } \\
\text { - Retrabalhamento progressivo } \\
\text { - Aumento da competência } \\
\text { - A partir de } 25 \mathrm{~cm} \text { ocorre aumento do aporte } \\
\text { terrigeno ligado à dinâmica fluvial } \\
\text { - Influência de fonte gnáissica }\end{array}$ \\
\hline & $\begin{array}{l}\text { Palinologia } \\
\text { - Aumento na concentração de palinomorfos } \\
\text { - Ligeira abertura florestal } \\
\text { - Sucessão florestal e posterior restabelecimento de } \\
\text { nos últimos } 3500 \text { anos }\end{array}$ & $\begin{array}{l}\text { Palinologia } \\
\text { - Sucessão florestal de encosta } \\
\text { - Clima frio e úmido } \\
\text { - Nos últimos } 5000 \text { anos A.P. ocorre o } \\
\text { restabelecimento da Floresta de Araucaria }\end{array}$ \\
\hline & $\begin{array}{l}\text { Geoquímica e isótopos } \\
\text { - Redução na influência de matéria orgânica de } \\
\text { plantas terrestres }\end{array}$ & $\begin{array}{l}\text { Geoquímica e isótopos } \\
\text { - Elevação do aporte e/ou preservação da matéria } \\
\text { orgânica que diminui nos últimos } 25 \mathrm{~cm} \\
\text { - Incremento na influência de algas } \\
\text { - Predominio de plantas C3 }\end{array}$ \\
\hline
\end{tabular}




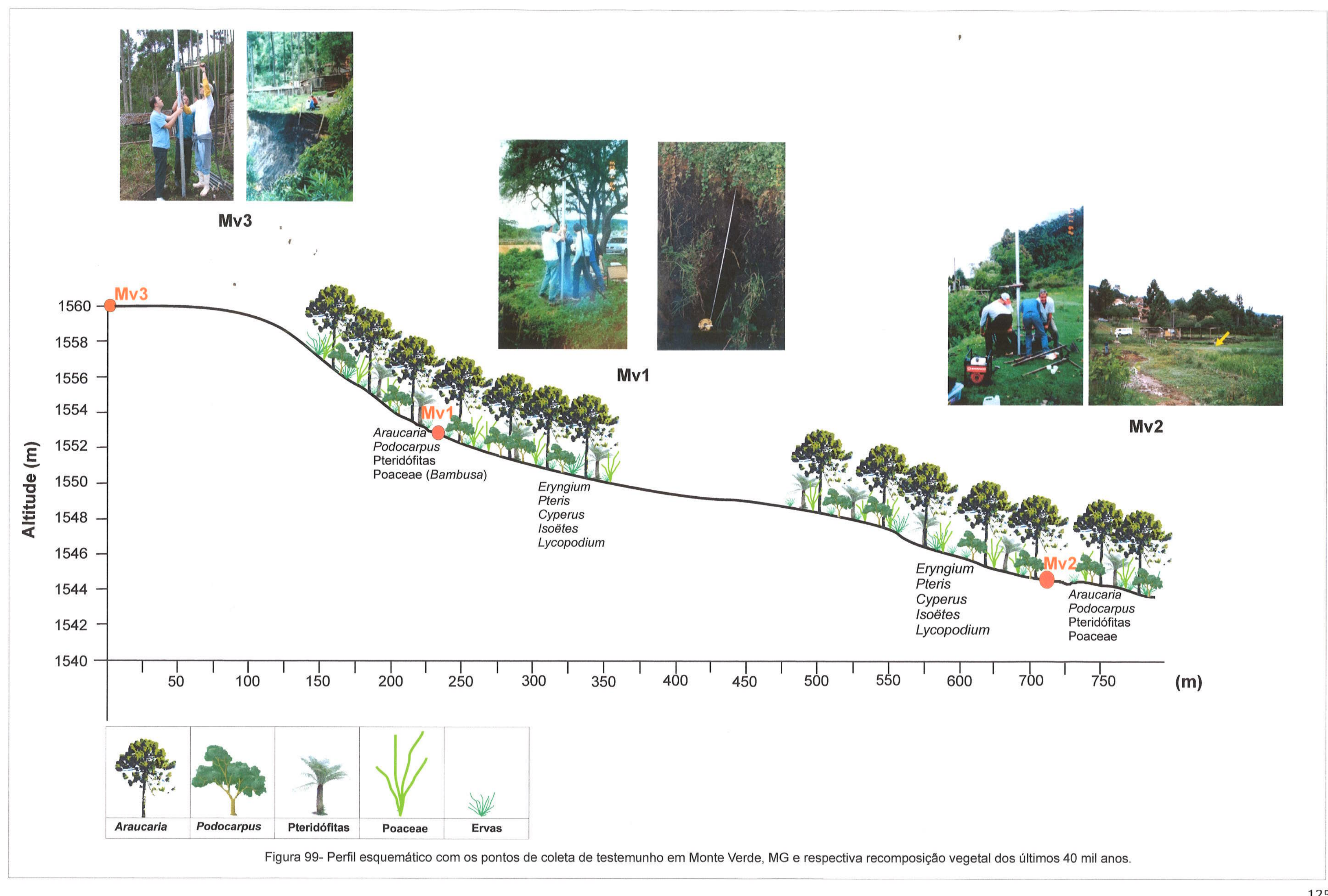




\section{CONCLUSÕES FINAIS}

A análise integrada de variáveis sedimentológicas, palinológicas, geoquímicas e isotópicas nos testemunhos MV1 e MV2, coletados no vale do Córrego do Cadete, região de Monte Verde, sul de Minas Gerais, permitiu a reconstrução da história ambiental da Floresta de Araucária nesta porção da serra da Mantiqueira, meta geral proposta para este trabalho.

As variáveis relativas a taxa deposicional, granulometria e minerais pesados apresentaram relativa sincronia com as mudanças inferidas pela concentração de palinomorfos e estas, por sua vez, com as indicadas pelas análises geoquímicas e isotópicas $\left(\delta^{15} \mathrm{~N}, \delta^{13} \mathrm{C}, \mathrm{N}_{\text {total }} \mathrm{C}_{\text {total }}\right.$ e razão $\left.\mathrm{C} / \mathrm{N}\right)$. É notável, por exemplo, a relativa coincidência entre ciclos de variação sedimentológica indicativos de aumento de proximalidade com ciclos de elevação da influência de algas, sugeridos por palinologia, aumento de $\delta^{15} \mathrm{~N}$ e redução de $\mathrm{C} / \mathrm{N}$.

O conjunto de resultados obtidos revelou informações paleoflorísticas sobre - UMG em Monte Verde, que puderam ser correlacionados com variáveis climáticas obtidas por outros estudos paleoambientais. No que se refere a esta comparação com estudos anteriores, o primeiro ponto a destacar é que os resultados palinológicos dos sedimentos depositados durante o UMG na área de estudo não apoiam a Hipótese dos Refúgios Florestais pleistocênicos, propostos para este setor da Região Sudeste por Ab'Saber (1982), uma vez que não houve troca vegetacional, por exemplo, de floresta subtropical por caatinga ou cerrados, que pudesse indicar substituição de clima úmido por semi-árido. Os dados do presente estudo demonstram que o UMG, em Monte Verde, manteve-se frio e úmido.

Estudos como os realizados por De Oliveira (1992), Colinvaux et al. (1999), Barberi (2001), Ledru (2001), Cruz et al. (2005, 2007, 2009), Siqueira (2006) e Pessenda et al. (2009) já haviam registrado clima frio e úmido durante o UMG em diferentes regiões do Brasil, em oposição ao clima seco interpretado para este mesmo período na serra dos Carajás (PA), por Absy et al. (1991), e às condições frias e mais secas que as atuais inferidas na Região Sul por Behling et al. (1995, $1997,2002)$. Esta aparente contradição entre parte dos registros palinológicos do periodo equivalente ao UMG pode ser tentativamente explicada pela 
compartimentação do clima do território brasileiro, nessa época, pela Zona de Convergência do Atlântico Sul (ZCAS), à semelhança do que se tem na dinâmica climática atual. Segundo esse modelo, as áreas ao norte e ao sul da ZCAS seriam menos úmidas que a faixa NW-SE diretamente afetada por esse cinturão de nebulosidade, o que favoreceria a troca, naquelas áreas, de floresta subtropical por vegetação de caatinga ou de cerrados. Assim, as áreas ao sul da ZCAS teriam a prevalecência no UMG de condições climáticas frias e mais secas enquanto as situadas ao norte da ZCAS indicariam clima quente e mais seco que o atual.

No presente estudo, notou-se a importância de se usar uma interpretação paleoambiental mais equilibrada da familia de ervas Poaceae, que, até recentemente, vinha sendo utilizada como indicadora de condições mais secas. Esta interpretação é incompatível com a realidade fitossociológica atual da Floresta de Araucária de Monte Verde, onde bambus ocorrem, em significativa concentração, sob o dossel fechado das árvores de Araucaria e Podocarpus. Em Monte Verde, esta familia é dominada por bambus dos gêneros Chusquea e Merostachys, tipicos de florestas fechadas e de grandes elevações no Brasil (De Oliveira, 1992; Colinvaux et al. 1999; De Oliveira et al., 2005).

Outra possibilidade de interpretação errônea está relacionada à família Asteraceae, que tem forte representatividade com o gênero Vernonia, em muitos estudos interpretado como elemento arbustivo. Nas florestas modernas de Monte Verde, entretanto, este gênero corresponde a uma árvore de grande porte, também presente na Floresta de Araucária. A correta interpretação depende da análise integrada de diferentes variáveis, estratégia que se tentou adotar neste estudo. Isso mostra a importância da utilização de multindicadores para melhor compreensão do registro sedimentar em determinada região.

As colunas sedimentares MV1 e MV2 foram depositadas em planície de inundação fluvial, em que variaram ao longo do tempo a proximidade e influência do canal e o aporte direto a partir das encostas, por rastejo e fluxos de massa, este possivelmente controlado pela densidade e porte da cobertura florestal. De acordo com os resultados analíticos obtidos, a evolução da região foi dividida em duas fases maiores, com significado paleoambiental. 
No intervalo de cerca de 40500 a $26000 / 21500$ anos A.P., os elementos polinicos indicam clima frio e úmido. A concentração de grãos de pólen arbóreos, embora com baixo grau de preservação, é suficiente para indicar a presença de vegetação florestal densa, o que se corrobora pelos dados geoquímicos indicativos de contribuição de plantas C3 com fonte de matéria orgância terrestre. A concentração relativamente baixa de $C_{\text {total }}$ e $N_{\text {total }}$ sugere diluição de matéria orgânica pelo aporte terrígeno, porém a taxas de sedimentação declinantes e com elevada exposição ao intemperismo. Estas condições teriam favorecido a destruição ou corrosão, por oxidação, de material polínico depositado neste intervalo de tempo. Os dados sedimentológicos deste intervalo indicam ainda perda gradual na competência do transporte e retenção seletiva de material mais grosso na fonte, portanto com aumento no tempo de distalidade.

Nos últimos 21500 a 26000 anos A.P., tem-se o incremento gradativo da cobertura vegetal em área e densidade, evidenciado pelo aumento na concentração de pólen arbóreo, o qual atinge média de 6000 a 8000 grãos por $\mathrm{cm}^{3}$. Fase de abertura florestal é, porém, identificada entre cerca de 17000 anos AP e o meio do Holoceno, com base na presença de gêneros característicos de sucessão florestal, caso de Cordia,Tabebuia e Alchornea, cuja variação de concentração é inversa a de Araucaria e de outros elementos encontrados na floresta moderna da região de Monte Verde, tais como Euterpe, Ilex, Lauraceae e Vernonia. Nesse mesmo intervalo de tempo, o aumento da umidade no sítio deposicional é evidenciado pelo incremento na concentração de algas, que atingem cerca de 1700 grãos por $\mathrm{cm}^{3}$, e pela elevação do $\delta^{15} \mathrm{~N}$.

Dentro dos últimos 5000 a 6000 anos A.P., tem-se o readensamento da Floresta de Araucária, com manutenção de brejos, sob condições climáticas frias e úmidas. Essa interpretação de umidade é reforçada pelo dados de $\delta^{15} \mathrm{~N}$ cujos valores são indicativos de influência relativamente forte de algas.

Os resultados sugerem que as mudanças climáticas desde o início da deposição dos sedimentos em Monte Verde não foram acentuadas a ponto de exercer grande impacto florístico e que houve predominio de Araucaria e elementos associados a essa floresta como Drymis, Eugenia, Hedyosmum, Ilex, Podocarpus, Symplocos, dentre outros, durante todo o intervalo estudado, sob condições climáticas frias e úmidas. 


\section{REFERÊNCIAS BIBLIOGRÁFICAS}

ABSY, M.L. 1979. A palynological study of Holocene sediments in the Amazon Basin. Amsterdam. Dissertation (PhD). University of Amsterdam.

ABSY, M.L.; CLEEF, A.; FOURNIER, M.; MARTIN, L.; SERVANT, M.; SIFEDDINE, A.; FERREIRA DA SILVA, M.; SOUBIES, F.; SUGUIO, K.; TURCQ, B.; VAN DER HAMMEN, T. 1991. Mise en evidence de quatre phases d'ouverture de la fôret dense dans le sud-est de l'Amazonie au tours des 60000 dernières années. Première comparaison avec d'autres dernières tropicales. Compte Rendi de l'Académie des Sciences de Paris. 312: 673678.

AB'SABER, A.N. 1982. The paleoclimatic and paleoecology of Brazilian Amazônia. In: Biological diversification in the tropics. New York: Columbia University Press, p. 41-59.

AGER, D.V. 1993. The nature of stratigraphical record. New York, J. Wiley, $151 \mathrm{p.}$

AMARAL, P.G.C.; LEDRU, M.P.; RICARDI-BRANCO, F.R.; GIANNINI, P.C.F. 2006. Late Holocene development of a mangrove ecosystem in southeastern Brazil (Itanhaém, state of São Paulo). Paleogeography, Paleoclimatology, Paleoecology, 241: 608-620.

AMARAL, P.G.C. 2008. Evolução da sedimentação lagunar Holocênica na região de Jaguaruna, estado de Santa Catarina: uma abordagem sedimentológica micropaleontológica integrada. Tese (Doutorado). 165p. Instituto de Geociências- Universidade de São Paulo.

AMARAL, P.G.C.; GIANNINI, P.C.F.; FORNARI, M.; NASCIMENTO Jr, D.R.; MENEZES, P.M.L.; SAWAKUCHI, A.O.; PESSENDA, L.C.R.; DE BLASIS, P. 2008. Evolução da sedimentação lagunar holocênica na região de Jaguaruna, Santa Catarina (Sul do Brasil): aplicação integrada de isótopos estáveis, razão $\mathrm{C} / \mathrm{N}$ e análise de diatomáceas. In: CONGRESSO DE GEOQUÍMICA DOS PAÍSES DE LÍNGUA PORTUGUESA, 9, Cabo Verde, Resumos...

AMARAL, P. G. C.; GIANNINI, P. C. F; SYLVESTRE, F.; PESSENDA, L. C. R.2011 . Paleoenvironmental reconstruction of a Late Quaternary lagoon system in Southern Brazil (Jaguaruna region, Santa Catarina statel) based on multi-proxies analysis. JQS. Journal of Quaternary Science (Print).

ANDERTON, R. 1985. Clastic facies models and facies analysis. In: BRENCHLEY, P.J. \& WILLIAMS, B.P.J. eds. Recent Developments and applied Aspects. Oxford, The Geol.Soc. - Blackwell Scientific Publ. p.31-47. 
BARBERI, M. 1994. Paleovegetação e paleoclima no Quaternário Tardio da Vereda de águas Emendadas, DF. Brasilia. Dissertação (Mestrado)Universidade de Brasília.

BARBERI, M.; SALGADO-LABORIAU, M.L.; SUGUIO, K. 2000. Paleovegetation and paleoclimate of Vereda de Águas Emendadas, central Brazil. Journal of South American Earth Sciences. 13: 241-254.

BARBERI, M. 2001. Mudanças paleoambientais na região dos cerrados do Planalto Central durante o Quaternário Tardio: o estudo da Lagoa Bonita, DF. Tese (Doutorado)- Instituto de Geociências, Universidade de São Paulo.

BAUERMANN, S.G. 2003. Análises palinológicas e evolução paleovegetacional e paleoambiental das turfeiras de Barrocadas e Águas Claras, planície costeira do Rio Grande do Sul, Brasil. Tese (Doutorado). Instituto de GeociênciasUniversidade Federal do Rio Grande do Sul. 137p.

BARROS, M.A.; BARTH, O.M.; MELLO, C.L.; MOURA, J.R.S.; PEIXOTO, M.N.O. 2000. História recente da vegetação e o uso da terra no médio vale do Rio Paraíba do Sul. Leandra, v.15, p. 47-57.

BARROSO, G.M.; PEIXOTO, A. L.; ICHASO, C.L.F.; GUIMARÃES, E.L. \& COSTA, C.G. 1991 a. Sistemática de angiospermas do Brasil. Vol. 2. Viçosa: UFV. $377 p$.

BARROSO, G.M.; PEIXOTO, A. L.; ICHASO, C.L.F.; GUIMARÃES, E.L. \& COSTA, C.G. 1991b. Sistemática de angiospermas do Brasil. Vol. 3. Viçosa: UFV. $326 p$.

BARROSO, G.M.; PEIXOTO, A. L.; ICHASO, C.L.F.; GUIMARÃES, E.L. \& COSTA, C.G. 2002. Sistemática de angiospermas do Brasil. Vol. 1, 2. ed. Viçosa: UFV. 309p.

BEHLING, H. 1995. A hight resolution Holocene pollen record from Lago do Pires, SE Brazil: vegetation, climate and fire history. Journal of Paleolimnology, v. 14, p. $253-268$.

BEHLING, H. 1995a. A high resolution Holocene pollen record from Lago do Pires, SE Brazil: vegetation, climate and fire history. Journal of Paleolimnology, 14 (3): 253-268.

BEHLING, H.; NEGRELLE, R.R.B.; COLINVAUX, P.A. 1996. Modern pollen rain data from the tropical Atlantic rain forest, Reserva Volta Velha, South Brazil. Review of Paleobotany and Palynology. 97: 287-299.

BEHLING, H. 1997 a. Late Quaternary vegetation climate and fire history of the Araucaria forest and campos region from Serra Campos Gerais, Paraná State (South Brazil). Review of Paleobotany an Palynology, 97 (1/2): 109121. 
BEHLING, H. 1998. Late Quaternary vegetational and climatic changes in Brazil. Review of Palaeobotany and Palynology, 99: 143-156.

BEHLING, H.; ARZ, H.W.; PATZOLD, J.; WEFER, G. 2000. Late Quaternary vegetational and climate dynamics in northeastern Brazil, inferences from marine core GeoB 3104-1. Quaternary Science Reviews, 19: 981-994.

BEHLING, H. \& NEGRELLE, R. 2001. Tropical rain forest and climate dynamics of the Atlantic Lowland, southern Brazil, during the Late Quaternary. Quaternary Research, v.56, p. 383-389.

BEHLING, H. 2002. South and Southeast Brazilian grasslands during Late Quaternary times: a synthesis. Palaeogeography, Palaeoclimatology, Palaeoecology, 177: 19-27.

BEHLING, H. 2002a. Late Quaternary vegetation and climate dynamics in southeastern Amazonia interfered from Lagoa da Confusão in Tocantins State, northern Brazil. Amazoniana. 17: 27-40.

BEZERRA, M.A.O.1999. O uso de multi-traçadores na reconstrução do Holoceno no Pantanal Mato Grossense, Corumbá, MS. São Carlos. Tese (Doutorado)Departamento de Química, Universidade Federal de São Carlos.

BISSA, W.M.; YBERT, J.P.; CATHARINO, E.L.M.; KUTNER, M. 2000. Evolução paleoambiental na planície costeira do Baixo Ribeira durante a ocupação sambaqueira. Revista do Museu de Arqueologia e Etnologia, v.10, p.89-102.

BISTRICHI, C. A. 2001. Análise estratigráfica e Geomorfológica do Cenozóico da Região de Atibaia-Bragança Paulista, Estado de São Paulo. Dissertação (Doutorado)- Instituto de Geociências e Ciências Exatas/UNESP. Rio Claro.184p.

BRADE, A.C. 1956. A Flora do Parque Nacional do Itatiaia. Boletim do Parque Nacional do Itatiaia. Rio de Janeiro. 5:1-113.

BRULAND, K. W.; BIENFANG, P. K.; BISHOP, J.K.B.; EGLINTON, G.; ITTEKKOT, V.A.W.; LAMPITT,R.; SARNTHEIN, M.; THIEDE, J.; WALSH, J. J.; WEFER, G. 1989. Group report: flux to the seafloor. In: Berger, W. H.; Smetacek, V. S.; Wefer, G. (eds.). Productivity of the Ocean: Present and Past. New York (Wiley), p. 193-215.

BOOM, A.; MARCHANT, R.; HOOGHIEMSTRA, H.; DAMSTÉ, J.S.S. 2002. $\mathrm{CO}_{2}$ and temperature-controlled altitudinal shifts of $\mathrm{C}_{4}$ and $\mathrm{C}_{3^{-}}$dominated grasslands allow reconstruction of paleoatmospheric $p \mathrm{CO}_{2}$. Paleogeography, Paleoclimatology, Paleoecology. 177: 151-168. 
BUSH, M.B.; MILLER, M.C.; DE OLIVEIRA, P.E.; COLINVAUX, P.A. 2000. Two histories of environmental change and human disturbance in eastern lowland Amazônia. The Holocene. 10: 543-553.

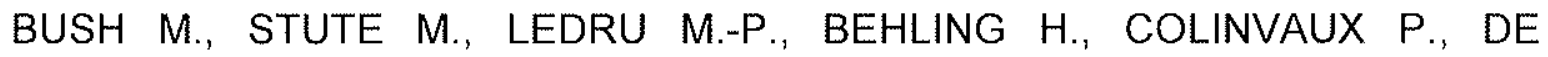
OLIVEIRA P., GRIMM E., HABERLE S., HOOGHIEMSTRA H., LEYDEN B., SALGADO-LABOURIAU M.L., WEBB, R. 2001. Paleotemperatures estimates for the lowland Americas between $30 \mathrm{~S}$ and $30 \mathrm{~N}$ at the last glacial maximum. In: Markgraf, V. (ed.) Present and Past Inter-Hemispheric Climate Linkages in the Americas and their Societal Effects. Academic Press. p.293-306.

BUSH, M.B. 2002. On the interpretation of fóssil Poaceae pollen in the lowland humid neotropics. Paleogeography, Paleoclimatology, Paleoecology. 177: $5-17$.

CARVER,R.E. 1971. Heavy mineral separation. In: CARVER, R.E. ed. Procedures in Sedimentary Petrology. New York, Wiley -Interscience. p. 427- 452.

CHAVES, S.A.M. 1997. Données palynologiques d'un milieu vegetal degradé dans la Vallée Moyenne du Rio Paraíba do Sul- Brésil. Quaternaire, v.8, n.1, p-49-54.

COLINVAUX, P. A. 1993. Pleistocene biogeography and diversity in tropical forests of South America.In: P. Goldblatt ed. Biological Reolationships Between Africa and South America. Yale University Press, New Haven, p. 473-499.

COLINVAUX, P.A.; DE OLIVEIRA, P.E.; MORENO, J.E.; MILLER, M.C.; BUSH, M.B. 1996. A long pollen record from lowland Amazônia: Forest and cooling in glacial times. Science. 274: 85-88.

COLINVAUX, P.A.; DE OLIVEIRA, P.E.; MORENO, J.E.P. 1999. Amazon pollen manual and atlas. London/New York: Gordon and Breach (Harwood). 310p.

COLINVAUX, P.A.; DE OLIVEIRA, P.E.; BUSH, M.B. 2000. Amazonian and neotropical plant communities on glacial time-scales: The failure of the aridity and refuge hypotheses. Quaternary Science. 19: 141-169.

COSTA, K.M.R. 2000. Análise palinológica e faciológica de depósitos fluviais recentes, Bananal (SP/RJ). Dissertação (Mestrado)- Departamento de Geologia, Instituto de Geologia, Universidade Federal do Rio de Janeiro. $74 \mathrm{p}$.

CRUZ, F.W. 2003. Estudo paleoclimático e paleoambiental a partir de registros geoquimicos quaternários em espeleotemas das regiões de Iporanga (SP) e Botuverá (SC). Tese (Doutorado)- Instituto de Geociências- Universidade de São Paulo. 134p. 
CRUZ, F.W.; BURNS, S.; KARMANN, I.; SHARP, W.; VUILLE, M.; CARDOSO, A.O.; FERRARI, J.A.; DIAS, P.L.S. \& VIANA-JÚNIOR, O. 2005. Isolationdriven changes in atmospheric circulation over the past $116 \mathrm{ky}$ in subtropical Brazil. Nature, 434: 63-66.

CRUZ, F.W., BURNS, S.J.; KARMANN, I.; SHARP, W.D.; VUILLE, M. 2006. Reconstruction of regional atmospheric circulation features during the late Pleistocene in subtropical Brazil from oxygen isotope composition of speleothems. Earth and Planetary Science Letters, 248: 494-506.

CRUZ, F. W; BURNS, S. J.; JERCINOVIC, M.; KARMANN, I.; SHARP, W. D. 2007. Evidence of rainfall variations in southern Brazil from trace-element ratios $(\mathrm{Mg} / \mathrm{Ca}$ and $\mathrm{Sr} / \mathrm{Ca})$ in a Late Pleistocene stalagmite. Geochimica et Cosmochimica Acta, v. 71, p. 2250-2263.

CRUZ, F.W.; VUILLE, M.; STEPHEN, J.B.; XIANFENG, W.; CHENG, $H_{\text {; }}$ WERNER, M.; LAWRENCE, E.R.; KARMANN, I.; AULER, A. NGUYEN, H. 2009. Orbitally driven east-west antiphasing of South American precipitation. Nature Geoscience. Publicação on line. 22 fevereiro de 2009.

DE OLIVEIRA, P.E. 1992. A palynological record of Late Quaternary vegetational and climatic change in Southeastern Brazil. Columbus, Ohio, USA. Tese (Doutorado)- The Ohio State University. 242p.

DE OLIVEIRA, P.E. 1996. Glacial cooling and forest disequilibrium in Western Amazonia. Anais da Academia Brasileira de Ciências. (1), 68: 130-138.

DE OLIVEIRA, P.E.; BARRETO, A.M.F.; SUGUIO, K. 1999 a. Late Pleistocene/Holocene climatic and vegetational history of the Brazilian caatinga: the fóssil dunes of the middle São Francisco river. Paleogeography, Paleoclimatology, Paleoecology. 152: 319-337.

DE OLIVEIRA, P.E.; BEZERRA, M.A.O; MOZETO, A.; ARAVENA, R. 1999b. Vegetação e clima do Quaternário Tardio do Pantanal Sul-Mato-Grossense: Palinologia da Lagoa Negra, Corumbá, MS. In: Congresso da ABEQUA, 7 , Porto Seguro. Anais.

DE OLIVEIRA, P.E. \& CURTIS, J. 2001. Vegetação e clima durante o último ciclo glacial na Amazônia equatorial: o registro palinológico da Serra do Maicuru. In: Congresso da ABEQUA, 8, Mariluz-Imbé. Boletim de Resumos.

DE OLIVEIRA, P.E.; BEHLING, H.; LEDRU, M.P.; BARBERI, M.; BUSH, M.; SALGADO-LABORIAU, M.L.; GARCIA, M.J.; MEDEANIC, S.; BARTH, O.M.; BARROS, M.A.; SCHEEL-YBERT, R. 2005. Paleovegetação e Paleoclimas do Quaternário do Brasil. In: Quaternário do Brasil. SOUZA, C.R.G.; SUGUIO, K.; OLIVEIRA, A.M.; DE OLIVEIRA, P.E. (org). Holos Ed. São Paulo-SP. p. 52-74. 
ERDTMAN, G. 1969. Pollen Morphology and Plant Taxonomy- Agiosperms. Stockholm.USA. 539 p.

EMERSON, S. \& HEDGES, J.I. 1988. Processes controling the organic carbon content of open ocean sediments. Paleoceanography, 3: 621-634.

FAEGRI, K. IVERSEN. 1989. The Principles of Pollination Ecology. 3rd. ed. Munksgaard, Copenhagen.

FERRAZ-VICENTINI, K.R. 1993. Análise Palinológica de uma Vereda em Cromínia, GO. Brasilia. Dissertação (Mestrado)- Departamento de Ecologia, Universidade de Brasilia. 87p.

FERRAZ-VICENTINI, K.R. \& SALGADO-LABORIAU, M.L. 1996. Palynological analysis of a palm swamp in Central Brazil. Journal of South American Earth Sciences. (3/4), 9: 207-219.

GAN, M. A.; V. E. KOUSKY; C. F. ROPELEWSKI. 2004. The South America Monsoon Circulation and Its Relationship to Rainfall over West-Central Brazil. J. Climate, v. 17, p. $47-66$.

GARCIA, M.J. 1994. Palinologia de Turfeiras Quaternárias do Médio Vale do Rio Paraíba do Sul, Estado de São Paulo. Tese (Doutorado) - Instituto de Geociências ,Universidade de São Paulo.354p.

GARCIA, M.J.; DE OLIVEIRA, P.E.; SIQUEIRA, E.; FERNANDES, R.S. 2004. A Holocene vegetational and climatic record from the Atlantic rainforest belt of coastal State of São Paulo, SE Brazil. Review of Palynology and Paleobotany. 131: 182-199.

GALEHOUSE,J.S. 1971b. Sedimentation analysis. In: CARVER, R.E.ed. Procedures in Sedimentary Petrology. New York, Wiley-Interscience. p.6994.

GIANNINI, P.C.F. (1993). Sistemas Deposicionais no Quaternário Costeiro entre Jaguaruna e Imbituba, SC. 2v. 439p. (Tese de Doutorado)- Instituto de Geociências, Universidade de São Paulo.

GIANNINI, P.C.F. 1999. Programa Momentos.123. Planilha Lotus.123. São Paulo, IG-USP (sem patente).

GIANNINI, P. C. F.; GUEDES, C. C. F. ; ASSINE, M. L. ; ANGULO, R. J. ; SOUZA, M. C.; PESSENDA, L. C. R. ; TATUMI, S. H. . Variação transversal e longitudinal de propriedades sedimentológicas nos cordões litorâneos da ilha Comprida, litoral sul paulista. In: IX Congresso da Associação Brasileira de Estudos do Quaternário, 2003, Recife, PE. Anais...Recife, PE : Abequa, 2003. 
GIANNINI, P. C. F. ; SAWAKUCHI, A. O. ; WARREN, L. V. ; ALMEIDA, R. P. ; BITTENCOURT, L. R. ; NASCIMENTO JR., D. R. . Análise de fácies da Formação Teresina na região entre o centro-sul do Estado de São Paulo e o norte do Paraná. In: Congresso Brasileiro de Geologia, 2004, Araxá, MG. Anais..., 2004.

GIANNINI, P.C.F.; ASSINE, M.L.; BARBOSA, L.; BARRETO, A.M.F.; CARVALHO, A.M.; CLAUDINO-SALES, V.; MAIA, L.P.; MARTINHO, C.T.; PEULVAST, J.P.; SAWAKUCHI, A.O.; TOMAZELLI, L.J. 2005. Dunas eólicas costeiras e interiores. In: SOUZA, C.R.G.; SUGUIO, K.; OLIVEIRA, P.E.; OLIVEIRA. A.M. ed. Quaternário do Brasil. Abequa, ANP, FAPESP, IG, UnG. Ribeirão Preto, SP, Holos Editora, cap. 11, p.235-257.

GIANNINI, P. C. F.; NASCIMENTO JR., D. R. 2005. Momento-expansão (calcula e tabula parâmetros estatísticos de distribuição granulométrica pela técnica dos momentos de Pearson para lotes de até 200 amostras).

GIANNINI, P.C.F. 2007. Dinâmica de Sistemas Deposicionais Eólicos Costeiros no Quaternário do Brasil. Tese (Livre-Docência) - Instituto de Geociências, Universidade de São Paulo. 205p.

GUEDES, C.C.F. 2009. Evolução Sedimentar Quaternária da llha Comprida, Estado de São Paulo. São Paulo, Programa de Pós-Graduação em Geoquímica e Geotectônica, IG-USP. Dissertação de Mestrado (ined.).

GRIMM, E. C. 1987. CONISS: A Fortran 77 program for stratigrafhically constrained cluster analysis by the method of the incremental sum of squares. Pergamon Journal, 13:13-35.

HAMMER, V. 1984. The Quaternary of Columbia. vol.10- Guia para Identificação de Palinomorfos.

HABERLE, S. G. 1997. Upper Quaternary vegetation and climate history of the Amazonian basin: correlating marine and terrestrial pollen records. In: R. D. Flood, D.J.W. Piper, Klazus, A.; Peterson (eds.). Proceedings of the Ocean Drilling Program, Scientific Results, n.155, p.381-396.

HEDGES, J.I.; CLARK, W.A.; QUAY, A.D.; RICHEY, J.E.; DEVOL, A.H.; DE SANTOS, U. 1986. Compositions and fluxes particulate organic material in Amazon River. Limnology Oceanograph. 31: 717-738.

HUBERT,J.F. 1962. A zircon-tourmaline-rutile maturity index and the interdependence of the composicion of heavy mineral assemblages with the gross composition and texture of sandstones. J.Sediment.Petrol., 32 (3):440450.

IPT. 1981. Mapa Geológico do Estado de São Paulo. São Paulo, Instituto de Pesquisas Tecnológicas. 
KERRY, H.C. 2009. South American climate variability and change: Remote and Regional forcing processes. Cap. 8. P.201-221. In: Vimeux, F.; Sylvestre, F.; Khodri, M. (eds) Past Climate Variability in South America and Surrouding regions: From the last glacial maximum to the Holocene. $421 \mathrm{p}$.

KORVIN, G. 1992. Fractal models in the earth sciences. Elsevier, Amsterdam, 396 p.

JOLLY, D. \& HAXELTINE, A. 1997. Effect of Low Glacial atmospheric $\mathrm{CO}_{2}$ on Tropical African montane vegetation. Science. 276: 786-788.

JOLY, A. B. 1998. Botânica: Introdução à taxonomia vegetal. Companhia Editora Nacional, São Paulo. $12^{\circ}$ ed. $777 p$.

KLEIN, R.M. 1975. Southern Brazilian phytogeographic features and the probable influence of Upper Quaternary climatic changes in the floristic distribution. International Symposium on the Quaternary- Curitiba- Southern Brazil. July 15-31. Boletim Paranaense Geociências. 33: 67-88.

KUHRY, P. 1977. Paleobotanical- Paleoecological studies of Tropical high Andean Peatbog Section- Colombia- Guia para Identificação de Palinomorfos. 219 p.

KRUMBEIN.W.C. 1938. Size frequency distribution of sediments and the normal phi curve. J.Sediment.Petrol.,8 (1):84-90.

LEDRU, M.P. 1993. Late Quaternary environmental and climatic changes in Central Brazil. Quaternary. 39: 90-98.

LEDRU, M.P.; BERTAUX, J.; SIFEDDINE, A. 1998. Absence of Last Glacial Maximum records in lowland tropical forests. 49: 233-237.

LEDRU, M.P.; CAMPELLO, R.C.; LANDIM, D.; DOMINGUEZ, J.M.; MARTIN, L.; MOURGUIART, P.; SIFEDDINE, A.; TURCQ, B. 2001. Late-glacial cooling in Amazonia inferred from pollen at Lagoa do Caçó, Northern Brazil. Quaternary Research. 55: 47-56.

LEDRU, M.P.; MOURGUIART, P.; CECCANTINI, G.; TURCQ, B.; SIFEDDINE, A. 2002. Tropical climates in the game of two hemispheres revealed by abrupt climatic change. Geology, v.30., p.275-278.

LORSCHEITTER, M.L.; ASHRAF, A.R.; WINDISCH, P.G. \& MOSBRUGGER, V. 1998. Pteridophyta spores of Rio Grande do Sul Flora, Brazil, Part I. Paleontographica Abt. B, 246: 1 - 113.

LORSCHEITTER, M.L.; ASHRAF, A.R.; WINDISCH, P.G.; MOSBRUGGER, V. 1999. Pteridophyta spores of Rio Grande do Sul Flora, Brazil, Part II. Paleontographica Abt. B. Bd. 251: 72 - 235. 
LORSCHEITTER, M.L.; ASHRAF, A.R.; WINDISCH, P.G.; MOSBRUGGER, V. 2000. Pteridophyta spores of Rio grande do sul flora, Brazil. Part III Stuttgart. Paleontographica Abt. B. 260: 1-165.

LORSCHEITTER, M.L.; ASHRAF, A.R.; WINDISCH, P.G.; MOSBRUGGER, V. 2001. Pteridophyta spores of Rio grande do sul flora, Brazil. Part IV. Stuttgart. Paleontographica Abt. Bd. 263: 1-159.

LORENZI, H. (1992). Árvores Brasileiras: Manual de Identificação e Cultivo de Plantas Arbóreas Nativas do Brasil. Ed. Plantarum, Nova Odessa, SP, 352 p.

MCLAREN,P. 1981. An interpretation of trends in grain size measures. J. Sediment. Petrol., 51(2):611-624.

MCLAREN, P. \& BOWLES, D. 1985. The effects of sediment transport on grainsize distributions. J. Sediment. Petrol., 55 (4): 457-470.

MAYLE, F.E. \& BEHLING, D.J. 2000. Late Quaternary changes in Amazonian ecosystems and their implications for global carbon cycling. Palaeogeography, Paleoecology, Palaeoclimatology, 214: 11-25.

MARKGRAF \& D'ANTONI, 1978. Polen Flora of Argentina- Guia para Identificação de Palinomorfos.

MARTIN, L.; BERTAUX, J.; CORRĖGE, T.; LEDRU, M.P.; MOURGUIART, P.; SIFEDDINE, A.; SOUBIĖS, F.; WIRRMANN, D.; SUGUIO, K.; TURCQ, B. 1997. Astronomical forcing of contrasting rainfall changes in tropical South America between 12,400 and 8800 cal yr B.P.Quaternary Research, 47: 117122.

MARTIN, L.; SUGUIO, K.; FLEXOR, J.M.; AZEVEDO, A.E.G. 1988. Mapa Geológico do Quaternário Costeiro dos Estados do Paraná e Santa Catarina. Brasilia, DNPM. 40 p, 2 mapas. (Série Geologia, 28).

MARCHANT, R.; BOOM, A.; HOOGHIEMSTRA, H. 2002. Pollen-based biome reconstructions for the past 450,000 years from the Funza-2 core, Colombia: comparisons with model-based vegetations reconstructions. Paleogeography, Paleoclimatology, Paleoecology. 177: 29-45.

MELO, M.S.; SINFRÔNIO, E.A.S.; GIANNINI, P.C.F.; FACHINI, M.; VICTORINO, M.C. 2004. Manual de Procedimentos Analiticos. São Paulo, IG-USP, Laboratório de Sedimentologia. 45p.

MELHEM, T.S.; CRUZ-BARROS, M.A.V.; CORREA, A.M.S.; MAKINOWATANABE, $H_{\text {.; }}$ SILVESTRE-CAPELATO, M.S.F.; ESTEVES, V.L.G. 2003. Variabilidade polínica em plantas de Campos do Jordão (São Paulo, Brasil).Boletim do Instituto de Botânica, 16:104p. 
MEYERS, P.A. 1994. Preservation of source identification of sedimentary organic matter during an after deposition. Chemical Geology, Amsterdam, v. 144, n. 3-4, p. 289-302.

MEYERS, P.A. \& LALLIER-VERGĖS, E. 1999. Lacustrine sedimentary organic matter records of Late Quaternary paleoclimates. Journal of Palaeolimnology, 21: 345-372.

MEYERS, P.A. 1997. Organic geochemical proxies of paleoceanographic, paleolimnologic and paleoclimatic processes. Org. Geochem., 5/6 (27): 213250.

MODENESI, M.C. \& MELHEM, T.S. 1992. Palynological data on a Holocene peat deposit tropical Brazil: preliminary paleoclimatic and paleoecological interpretations. Revista do Instituto Geológico, 13:7-15.

MOFATTO, M. 2005. Estudo multi/interdisciplinary de reconstrução da vegetação e clima do Parque Estadual da Serra do Mar- Núcleo Curucutu, São Paulo, SP no Quaternário tardio. Dissertação (Mestrado)- Centro de Energia Nuclear na Agricultura, Universidade de São Paulo.158p.

MORTON, A. C., HALLSWORTH, C.R. Processes controlling the composition of heavy mineral assemblages in sandstones: Sedimentary Geology, v. 124, p. 3-30. 1994.

MORTON, A.C.; HALLSWORTH, C.R. 1999. Processes controlling the composition of heavy mineral assemblages in sandstone. Sedimentary Geology, 124:3-29.

MURILLO, M.T. \& BLESS, M.J.M. (1978). Spores of recent Colombian Pteridohyta. II. Monolete spores. In: Review of Paleobotany and Palynology, 25: 319-365.

NASCIMENTO, L.R.S.L. 2008. Dinâmica vegetacional e climática holocênica da caatinga, na região do Parque Nacional do Catimbau, Buique- PE. Dissertação (Mestrado)- Centro de Tecnologia e Geociências, Universidade Federal de Pernambuco.70p.

NIMER, E. 1989. Climatologia do Brasil. $2^{a}$ edição. IBGE. Rio de Janeiro.421p.

NOGUÉS-PAEGLE, J. \& MO, K.C. 2000. Alternating wet and dry conditions over South America during summer. Monthly Weather Review, 125: 279-291.

ORSELLI, L. 1986. Climatologia. In: Gaplan - SC. Atlas de Santa Catarina. Rio de Janeiro, Aerofoto Cruzeiro. p.38-39.

PARIZZI, M.G. 1993. Dinâmica da Lagoa Santa com base em estudos palinológicos, geomorfológicos e geológicos de sua bacia. Dissertação 
(Mestrado)- Instituto de Geociências, Universidade Federal de Minas Gerais. $60 p$.

PARIZZI, M.G.; SALGADO-LABORIAU, M.L.; KOHLER, H.C. 1998. Gênesis and environmental history of Lagoa Santa: Southeastern Brazil. The Holocene, v. 8, n. 3, p. 311-321.

PARFENOFF, A.; POMEROL, C.; TOURENQ, J. 1970. Le Mineraux en Grains. Paris, Masson et Cience, 580p.

PESSENDA, L.C.R.; VALENCIA, E.P.E.; CAMARGO, P.B.; TELLES, E.C.C.; MARTINELLI, L.A.; CERRI, C.C.; ARAVENA, R.; ROZANSKI, K. 1996 a. Natural radiocarbon measurements in brazilian soils developed on basic rocks. Radiocarbon, v.38, n.2, p.203-208.

PESSENDA, L.C.R.; ARAVENA, R.; MELFI, A.J.; TELLES, E.C.C.; BOULET, R.; VALENCIA, E.P.E.; TOMAZELLO, M. 1996 b. The use of carbon isotopes (C$13, \mathrm{C}-14)$ in soil to evaluate vegetation changes during the Holocene in Central Brazil. Radiocarbon, v.38, n.2, p.191-201.

PESSENDA, L. C.; DE OLIVEIRA, P. E.; MOFATTO, M.; MEDEIROS, V. B.; FRANCISCHETTI, R.J. ; ARAVENA, R.; BENDASSOLI, J. A.; ZUNIGA, A.; SAAD, A.R.; ETCHEBEHERE, M. 2009. The evolution of a tropical rainforest/grassland mosaic in southeastern Brazil since 28,000 14C yr BP based on carbon isotopes and pollen records. Quaternary Research (Print), v. 71, p. $437-452$.

PESSENDA, L. C. R.; GOUVEIA, S. E. M.; FREITAS, H. A.; RIBEIRO, A. S.; ARAVENA, R.; BENDASSOLI, J A ; LEDRU, M. P.; SCHEEL-YBERT, R. 2005. Isótopos do carbono e suas aplicações em estudos paleoambientais. In: Quaternário do Brasil. SOUZA, C.L.; SUGUIO, K.; OLIVEIRA, A.M.S. \& DE OLIVEIRA, P.E. (org). Holos Ed. São Paulo-SP. p. 75-93.

PESSENDA , L.C.R., DE OLIVEIRA, P.E., MOFATTO, M., MEDEIROS, V.B.; GARCIA, R.J.F., ARAVENA, R., BENDASSOLI, J.A., LEITE, A.Z. SAAD, A.R., ETCHEBEHERE, M.L. 2009. The evolution of a tropical rainforest/grassland mosaic in southeastern Brazil since 28,000 yr BP based on carbon isotopes and pollen records. Quaternary Research, v. 71, p. 437452.

PETERSON, B.J. \& HOWARTH, R.W. 1987. Sulfur, carbon and nitrogen isotopes used to trace organic matter flow in the salt-marsh estuaries of Sapelo Island, Georgia. Limnology and Oceanography, 32: 1195-1213.

PETTIJOHN,F.J. 1957. Sedimentary Rocks. New York, Harper International, 3ed., $628 \mathrm{p}$.

RATTER, J.A.; BRIDGEWATER, S.; ATKINSON, R.; RIBEIRO, J.F. 1996. Analysis of the floristic composition of the Brazilian cerrado vegetation II: 
comparison of the woody vegetation of 98 areas. Edinburg Journal Botany, v. 53, p. $153-180$.

RODRIGUES, S.F.; BEHLING, H.; IRION, G.; MÜLLER, G. 2002. Evidence for Lake formation as a response to an inferred Holocene climatic transition in Brazil. Quaternary Research, San Diego, v.57, n.1, p.131-137.

ROUBIK, D.W. \& MORENO, J.E. 1991. Pollen and Spores of Barro Colorado Island. Vol.36. 268p.

SAADI, A. 1993. Neotectônica da plataforma brasileira: esboço e interpretação preliminares. Geonomos, $1(1): 1-15$.

SAIA, S.E.M.G. 2006. Reconstrução paleoambiental (vegetação e clima) no Quaternário tardio com base em estudo multi/interdisciplinar no Vale do Ribeira (sul do estado de São Paulo). Tese (Doutorado). Centro de Energia Nuclear na Agricultura- Universidade de São Paulo. 119p.

SADLER, P.M. 1981. Sediment accumulation rates and the completeness of stratigraphic sections. Journal of Geology, 89: 569-584.

SALGADO-LABORIAU, M.L. 1973. Contribuição à palinologia dos cerrados. Acad. Bras. Ciências, Rio de Janeiro. 291p.

SALGADO-LABORIAU, M.L. \& FERRAZ-VICENTINI, K.R. 1994. Fire in the Cerrado 32,000 years ago. Current Research in the Pleistocene. 11: 85-87.

SALGADO-LABORIAU, M.L.; CASSETI, V; FERRAZ-VICENTINI, K.R.; MARTIN, L.; SOUBIES, F.; SUGUIO, K.; TURCQ, B. 1997. Late Quaternary vegetational and climatic changes in cerrado and palm swamp from Central Brazil. Paleogeography, Paleoclimatology, Paleoecology. 128: 215-226.

SALGADO-LABORIAU, M.L.; BARBERI, M.; FERRAZ-VICENTINI, K.R.; PARIZZI, M.G. 1998. A dry climatic event during the Late Quaternary of tropical Brazil. Review of Palaeobotany and Palynology, v.99, p. 115-129.

SALGADO LABORIAU, M. 2007. Critérios e técnicas para o Quaternário. São Paulo. Edgar Blücher. 387p.

SANTOS, J.C. 2007. O Quaternário do Parque Nacional da Serra da Capivara, Piaui, Brasil: Morfoestrutura, Sedimentologia, Geocronologia e Paleoambientes. Tese (Doutorado). Centro de Tecnologia e Geociências, Universidade Federal de Pernambuco. 172p.

SCHWARTZ, D.; MARIOTTI, A.; LANFRANCHI, R.E.; GUILLET, C. 1986. $13 \mathrm{C} / 12 \mathrm{C}$ ratios of soil organic matter as indicator of vegetation changes in Congo. Geoderma, v.39, p. 97-103. 
SIQUEIRA, E.; GIANNINI, P.C.F.; DE OLIVEIRA, P.E. 2003. Paleoclimas do Quaternário tardio na região de Monte Verde, MG: Análises palinológicas e sedimentológicas preliminares. In: CONGRESSO DA ASSOCIAÇÃO BRASILEIRA DE ESTUDOS DO QUATERNÁRIO, IX. Recife/PE. Boletim de Resumos. (CD)

SIQUEIRA, E. 2006. Reconstrução da História Ambiental da Floresta de Araucaria, na Região de Monte Verde (MG), Setor Sul da Serra da Mantiqueira através de Análises Palinológicas e Sedimentológicas. Dissertação (Mestrado) Instituto de Geociências, Universidade de São Paulo. 142p.

STREET-PERROTT, F.A.; HUANG, Y.; PERROT, R.A.; EGLINTON, G.; BARKER, P.; KHELIFA, L.B.; HARKNESS, D.D.; OLAGO, D.O. 1997. Impact of lower atmospheric carbon dioxide on tropical mountain ecosystems. Science. 278: $1422-1426$.

STOCKMARR, J. 1971. Tablets with spores used in absolute pollen anlysis. Pollen et Spores, 13: 615-621.

SUGUIO, K. 1998. Dicionário de Geologia Sedimentar e áreas afins. Rio de Janeiro. Bertrand Brasil.

TANAKA, A.P.B. 2007. Evolução Sedimentar da Planície Retrobarreira de Campos Verdes (Laguna, SC) e os Sambaquis de Carniça. São Paulo, Instituto de Geociências da USP. 84 p. Trabalho de Formatura (inéd.).

TANAKA, A. P. B.; GIANNINI, P. C. F.; SAWAKUCHI, A. O. 2008. Rumo de crescimento progradacional e variação de minerais pesados na planicie de cordões litorâneos de Campos Verdes (Laguna, SC). In: Congresso Brasileiro de Geologia, 44, 2008, Curitiba, PR. Anais... Curitiba, PR: Sociedade Brasileira de Geologia (SBG). p. 969-969

TANAKA, A. P. B. ; GIANNINI, P. C. F. ; FORNARI, M. ; NASCIMENTO JR., D. R.; SAWAKUCHI, A. O. ; RODRIGUES, S. I. ; MENEZES, P. M. L. ; DEBLASIS, P. ; PORSANI, J. L. 2009. A planície costeira holocênica de Campos Verdes (Laguna, SC): evolução sedimentar inferida a partir de georradar (GPR), granulometria e minerais pesados. Revista Brasileira de Geociências, v. 39, p. $750-766$.

TRYON, R. M. \& TRYON, A. F. 1982. Ferns and Allied Plants - With Special Reference to Tropical América. Springer-Verlag. New York. Heidelverg. Berlin, 857p.

VAN ANDEL, T.H. 1958. Discussion: a defense of the term alterite. Journal of Sedimentary Petrology, 28: 234-235. 
VIDOTTO, E. 2008. Reconstrução paleoambiental (vegetação e clima) no Parque Estadual da liha do Cardoso- SP durante o Quaternário tardio. Tese (Doutorado). Centro de Energia Nuclear na Agricultura- Universidade de São Paulo. 199p.

ZHOU, J. \& LAU, K.M. 1998. Does a monsoon climate exist over South América? Journal of Climate, 11:1020-1040.

YAMAMOTO, J.K. 2000. A simple and practical device for wet elutriation of sediments. Journal of Sedimentary Research, 70(2): 423-426, 2000.

WALKER, R.G. 1976. Facies and facies models. General introduction. In: WALKER, R.G. ed. Facies Models. Toronto, Geosc. Canada, p.17. (Reprint Series, 1)

www.inpe.com.br (Acessado em 15 de abril de 2012)

www.earth.google.com.br (Acesado em 22 de março de 2012)

www.inmet.gov.br (Acessado em 28 de agosto de 2012) 
ANEXOS I à VII- Estampas dos principais palinomorfos quantificados nos testemunhos MV1 e MV2 


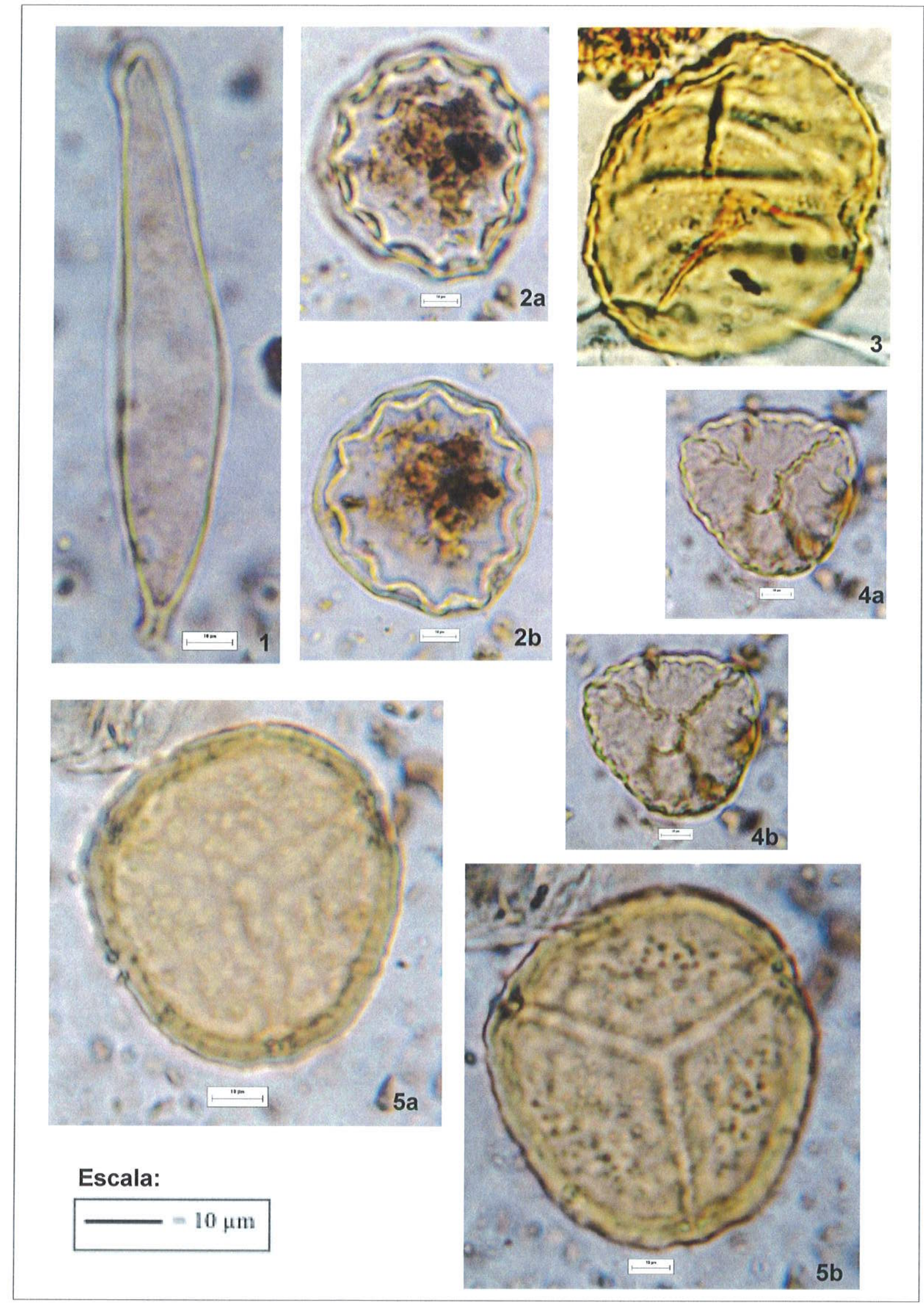

Estampa I- Figura 1 - Alga Indeterminada Tipo 01; Família ZygnemataceaeFigura 2 a/b - Zygnema sp; Família Anthocerotaceae- Figura 3- Anthoceros sp; Figura 4 a/b- Phaeoceros sp Tipo 01; Figura 5 a/b- Phaeoceros sp Tipo 02 


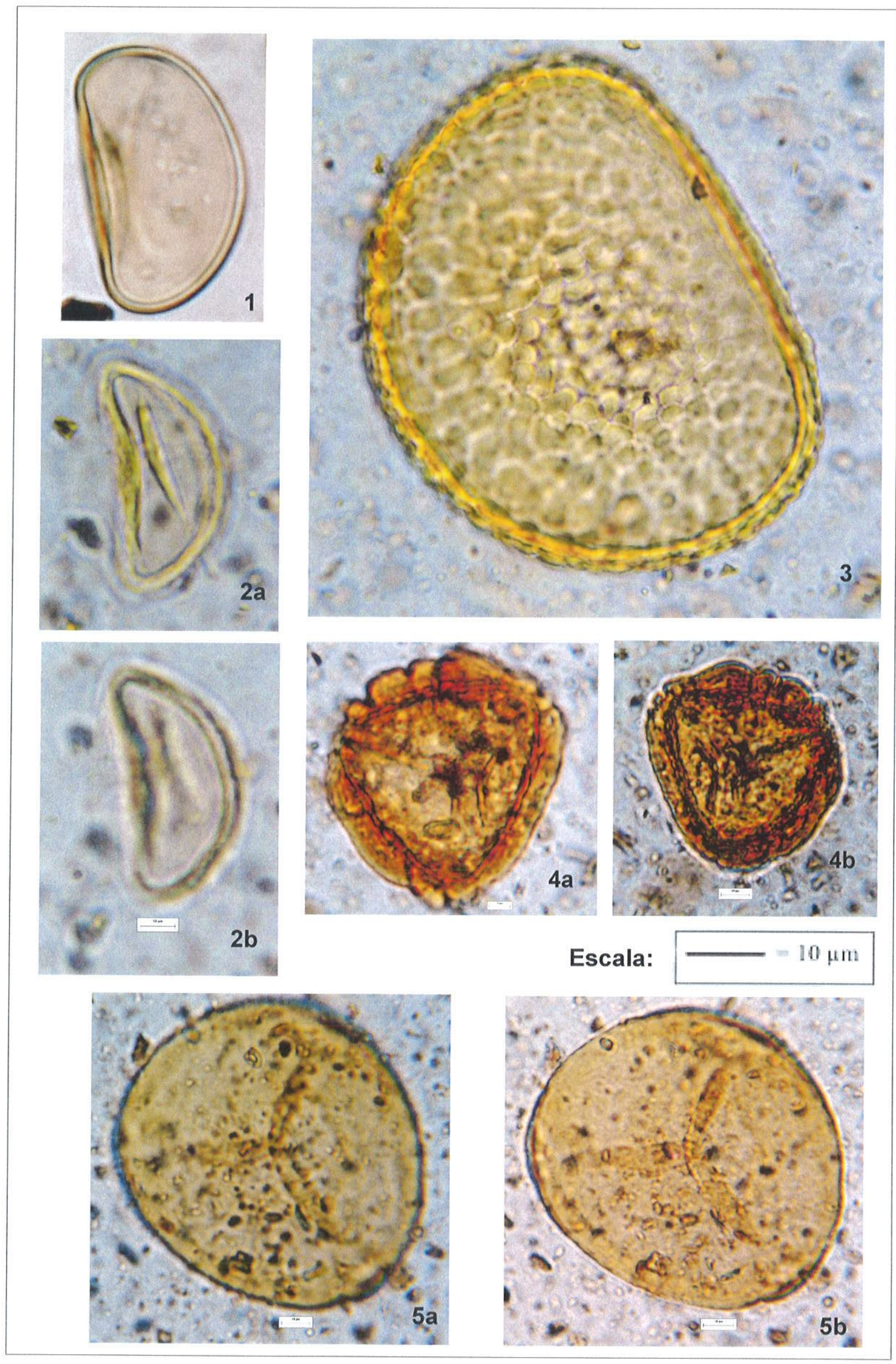

Estampa II- Família Gleicheniaceae - Figura 1 - Gleichenia sp Tipo 01; Família Isoetaceae- Figura 2a/b-Isoetes sp; Família Polypodiaceae-Figura 3-Polypodiaceae indeterminado Tipo 01; Família Cyatheaceae- Figura 04 a/b-Cyathea sp Tipo 1; Figura 5 a/b- Cyathea sp Tipo 2 


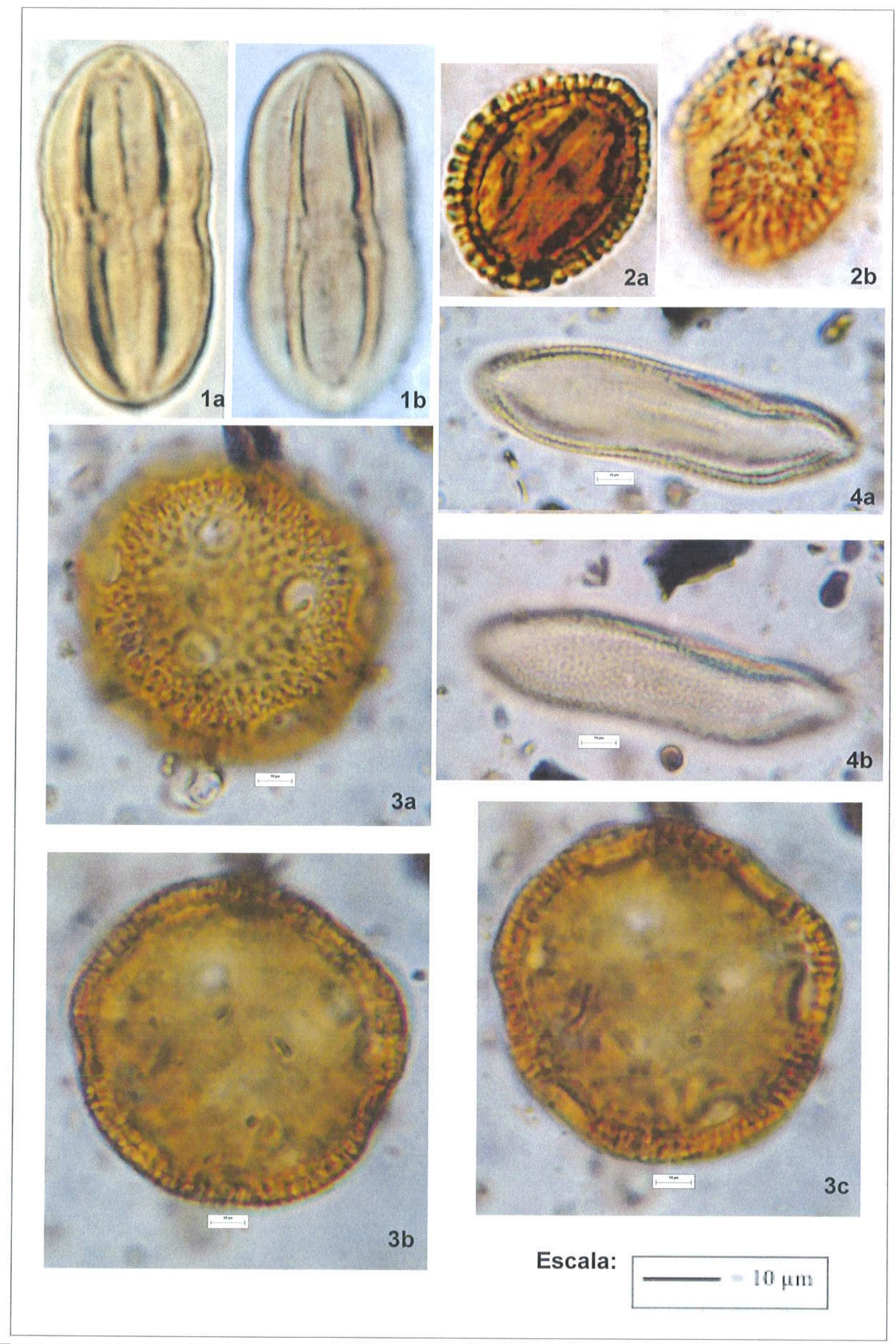

Estampa III - Família Apiaceae- Figura 1 a/b - Eryngiun sp; Família AquifoliaceaeFigura 2 a/b- Ilex sp; ;Família Allismataceae- Figura 3 a/b/c- Equinodorus sp; Família Arecaceae- Figura 4 a/b- Indeterminado $S$ 


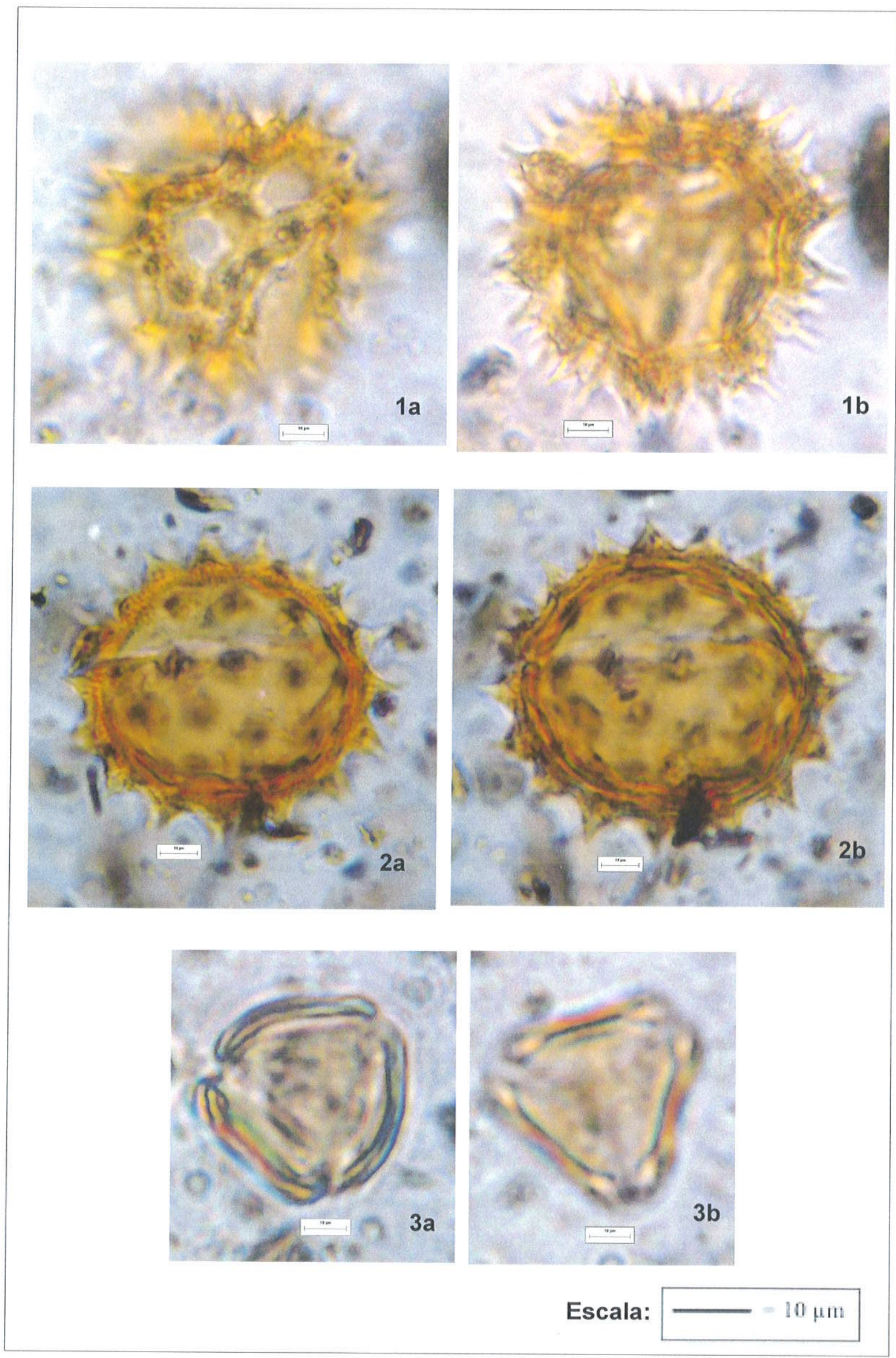

Estampa IV- Família Asteraceae - Figura 1 a/b - Asteraceae Tipo 01; Figura 2a/bAsteraceae Tipo 02; Família Begoniaceae- Figura 3 a/b- Jacaranda sp; 


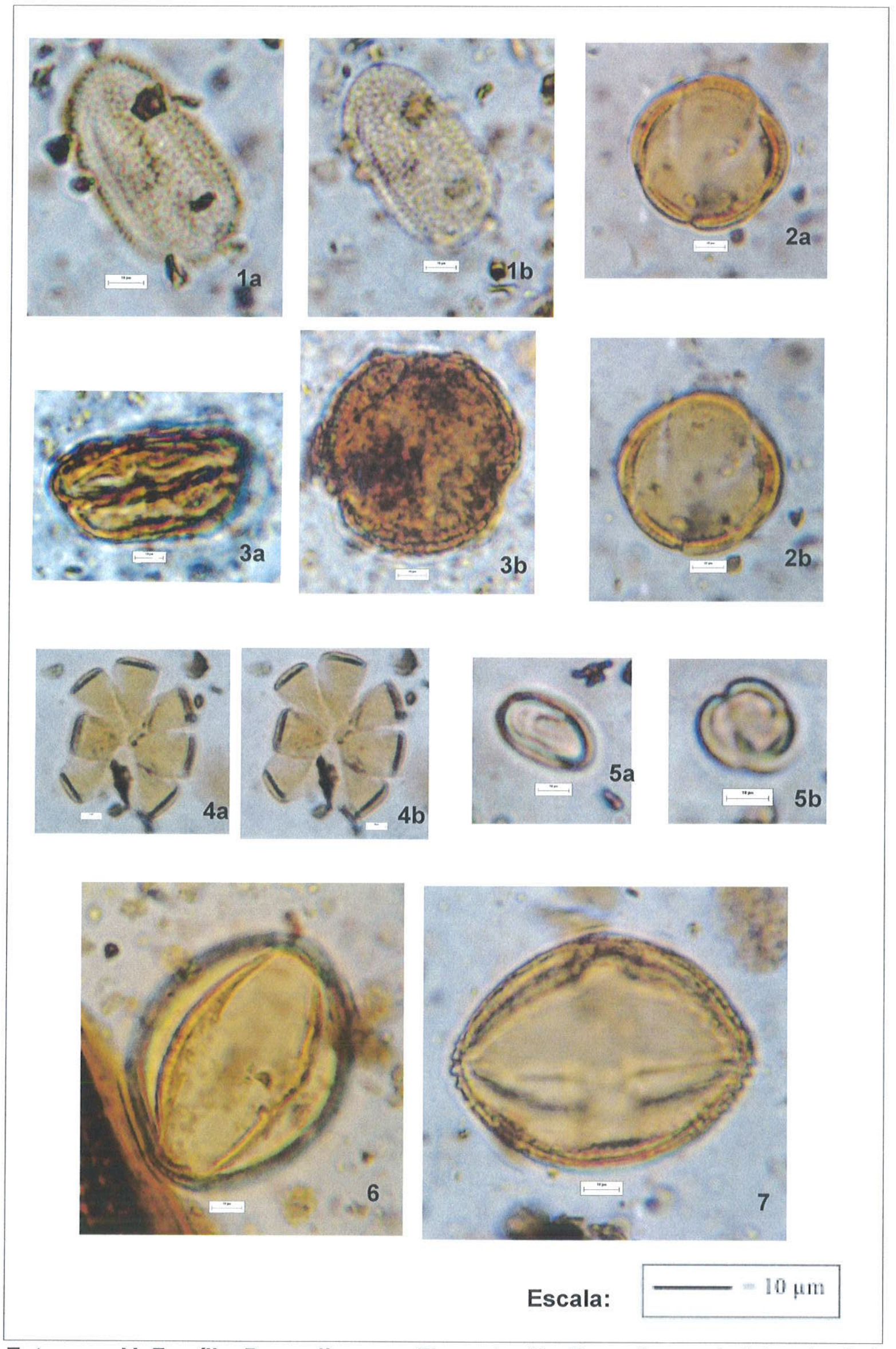

Estampa V-Família Bromeliaceae- Figura 1 a/ b- Bromeliaceae indeterminada I; Família Chloranthaceae - Figura $2 \mathrm{a} / \mathrm{b}$ Indeterminada Tipo 1; Figura $3 \mathrm{a} / \mathrm{b}$ Indeterminada Tipo II; Família Convolvulaceae- Figura 4 a/b Convolvulaceae indeterminada ; Família Cunoniaceae- Figura $5 \mathrm{a} / \mathrm{b}$ - Weinmannia sp; Família Euphorbiaceae- Figura 6- Indeterminada Tipo1l; Figura 7- Indeterminada Tipo 2 

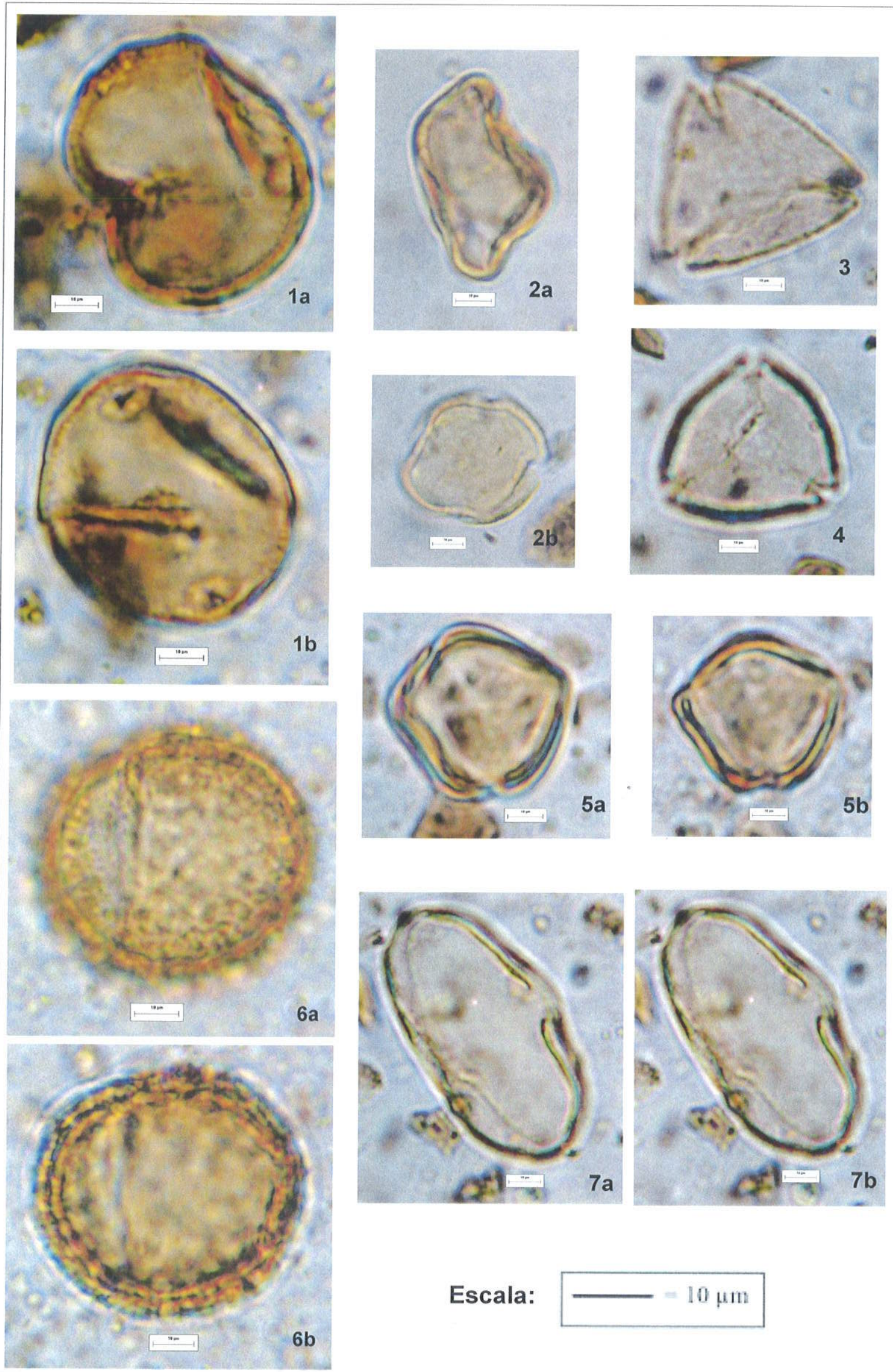

Estampa VI-Família Malphiguiaceae- Figura 1 a/b- Heteropteris sp; Família Myrsinaceae- Figura 2 a/b- Rapanea sp; Família Myrtaceae- Figura 3-Indeterminado Tipo 1; Figura 4- Indeterminado Tipo 2; Família Rhamnaceae - Figura 5 a/b- Gouania sp; Família Rubiaceae - Figura 6 a/b Indeterminada Tipo 1; Família Sapotaceae- Figura 7 a/b Pouteria sp 


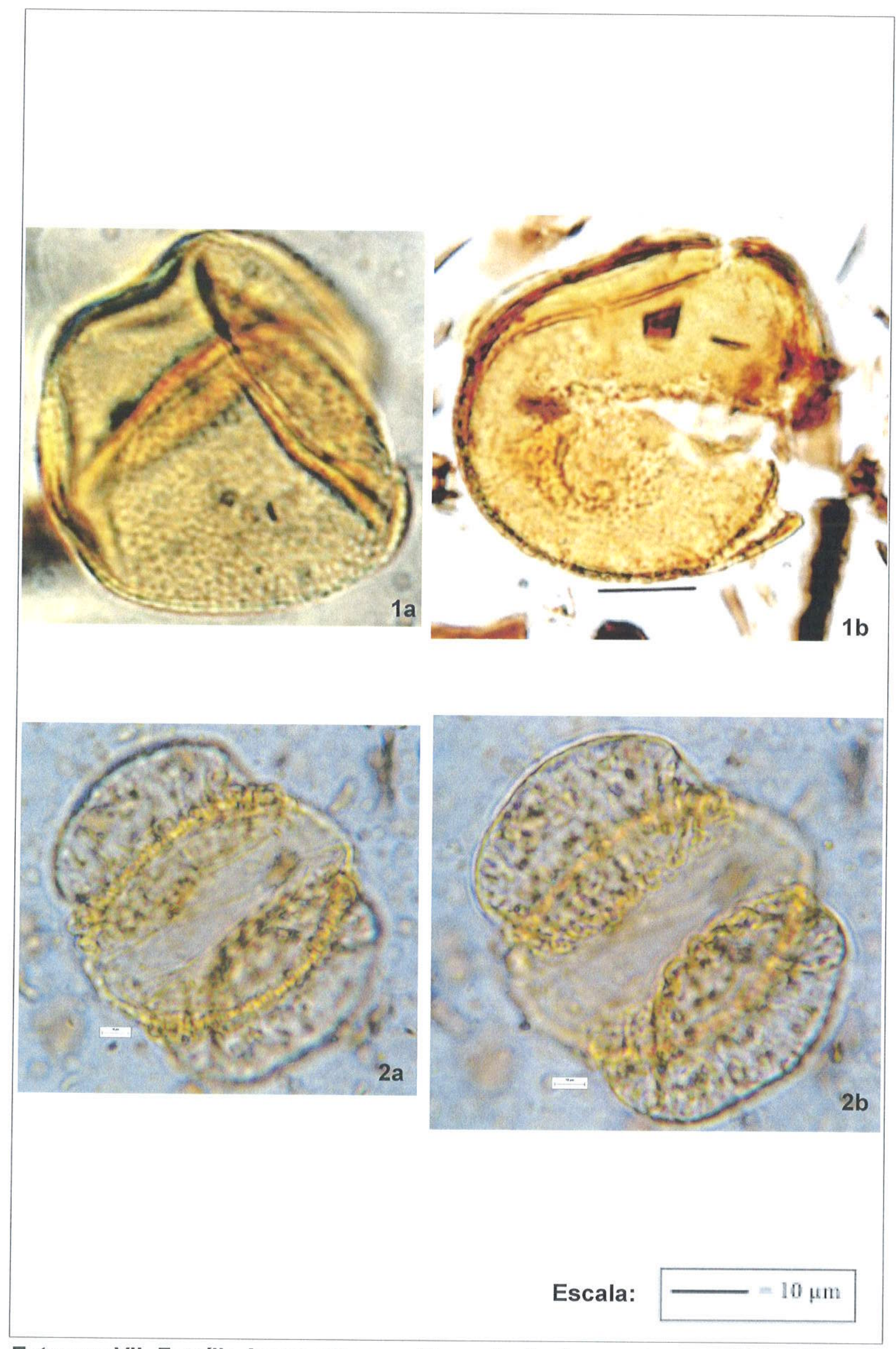

Estampa VII- Família Araucariaceae- Figura 1 a/b- Araucaria angustifolia; Figura 2 a/b/c/d- Podocarpus lambertii 


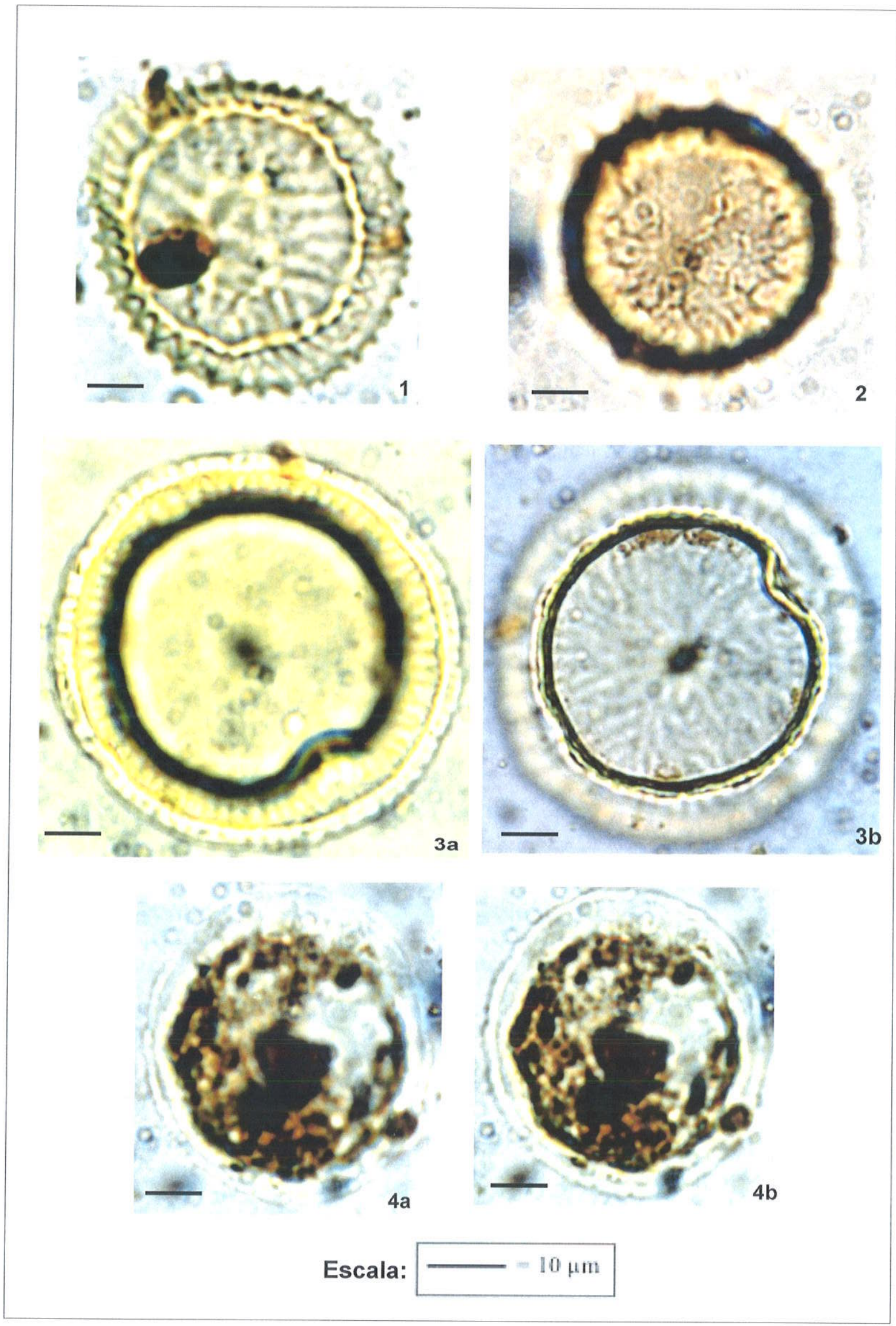

Estampa VIII- Família Zygnemataceae- Figura 1 - Debarya sp Tipo 01; Figura 2 Debarya sp Tipo 02; Figura 3 a/b- Debarya sp Tipo 3 ; Figura 4 a/b- Debarya sp Tipo 4 


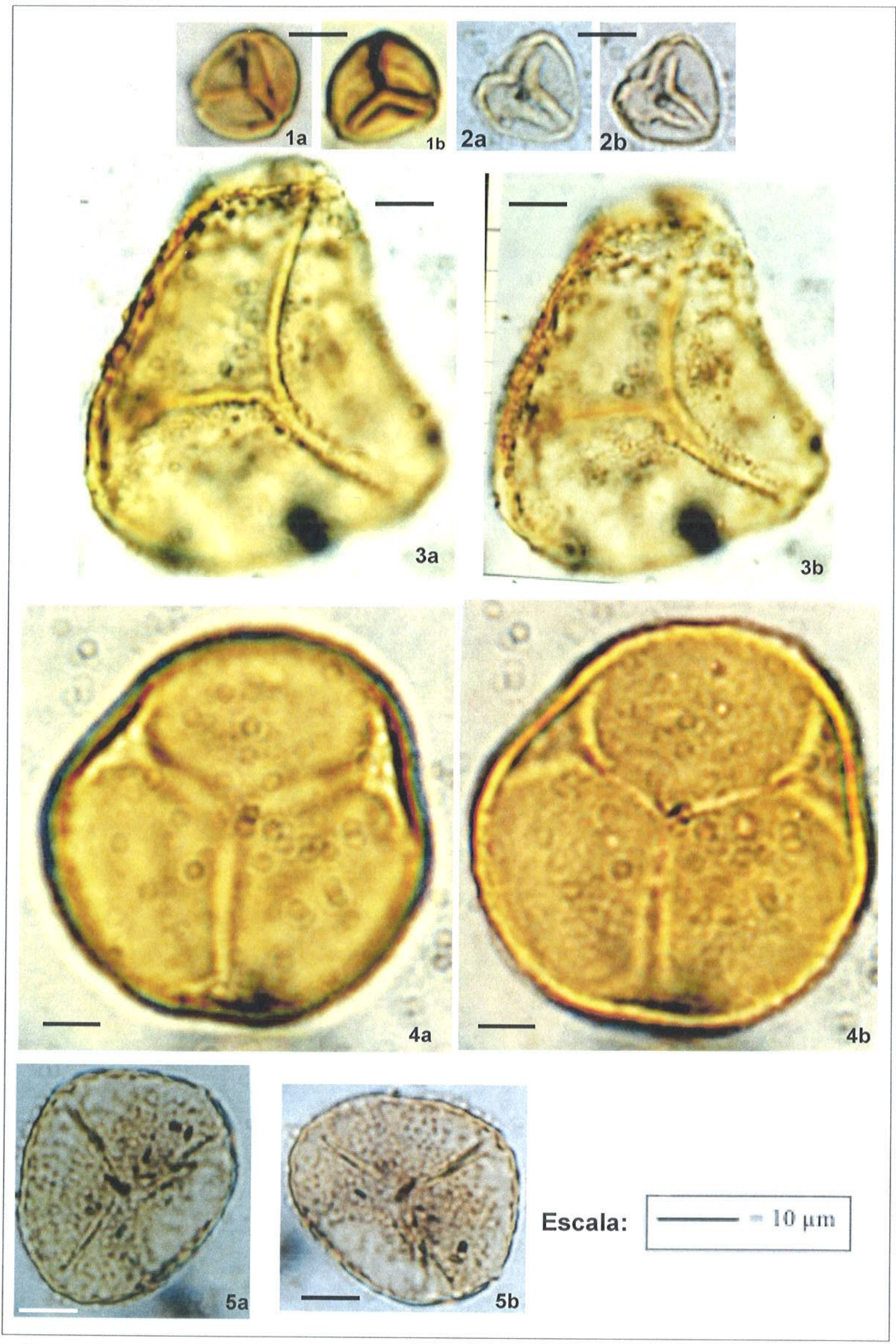

Estampa IX - Figura 1 a/b- Bryophyta indeterminada Tipo 01; Figura 2 a/bBryophyta indeterminada Tipo 02; Família Anthocerotaceae- ;Figura 3 a/bAnthoceros sp Tipo 02 ; Figura 4 a/b- Phaeoceros sp; Figura 5 a/b- Anthoceros sp Tipo 03 


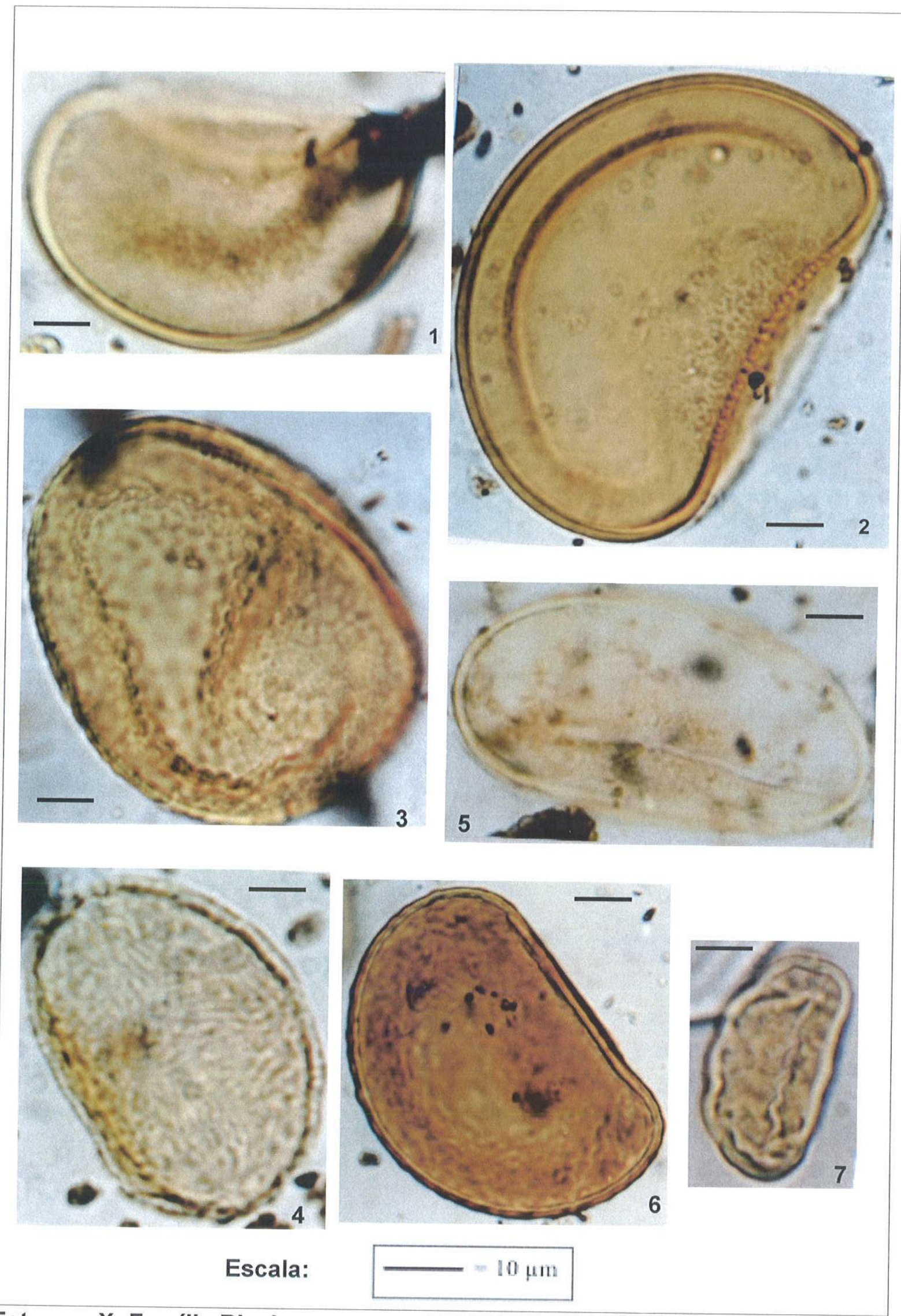

Estampa X- Família Blechnaceae- Figura 01-Blechnum sp; Família Gleicheniaceae Figura 2- Gleichenia sp Tipo 02; Família Polypodiaceae- Figuras 03- Polypodium sp; Figura 04- Polypodiaceae indeterminado Tipo 01; Figura 5- Polypodiaceae indeterminado Tipo 02 ; Figura 6- Polypodiaceae indeterminado Tipo 03; Família Denstaedtiaceae- Figura 7- Hypolepis sp 


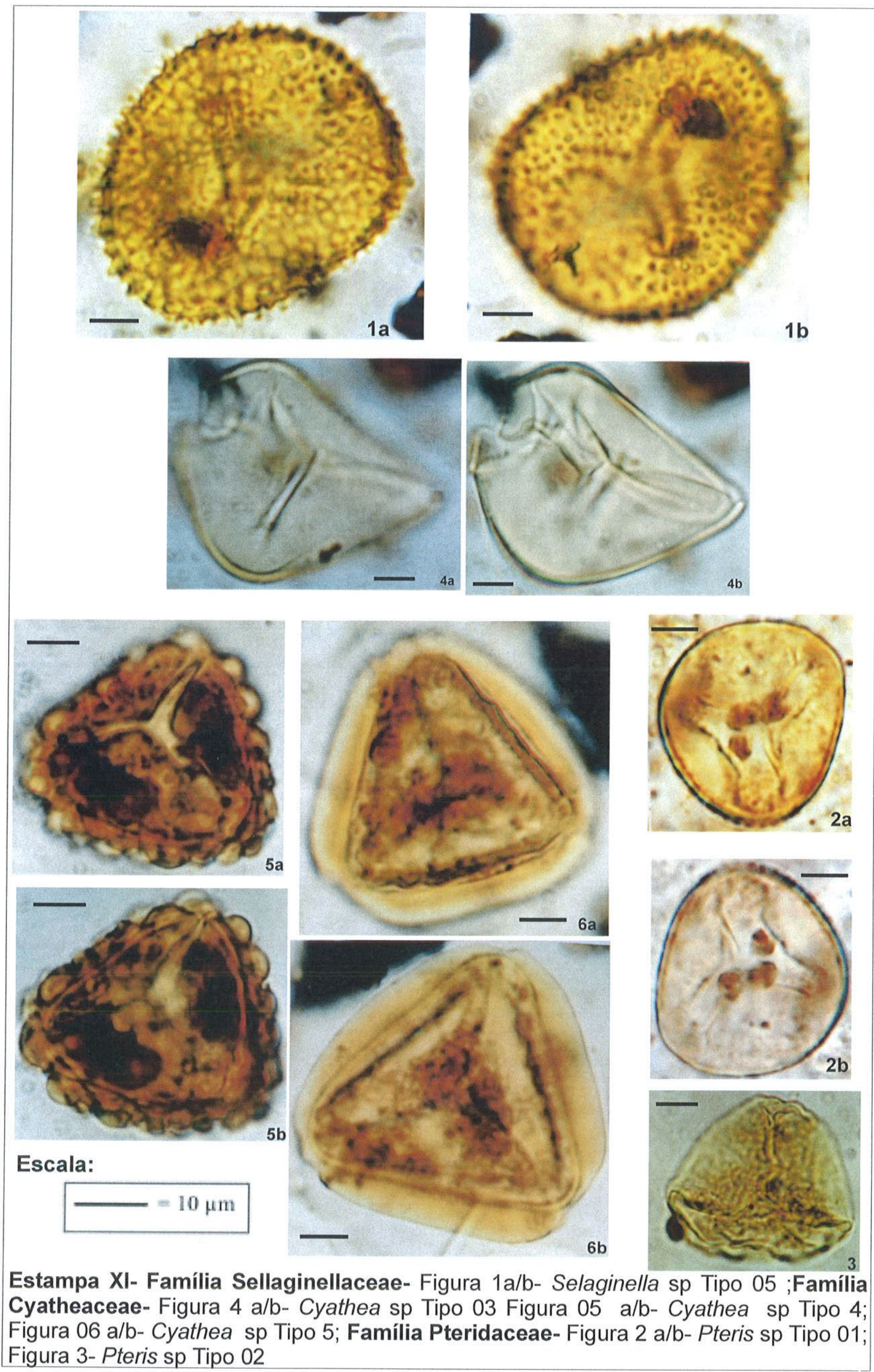



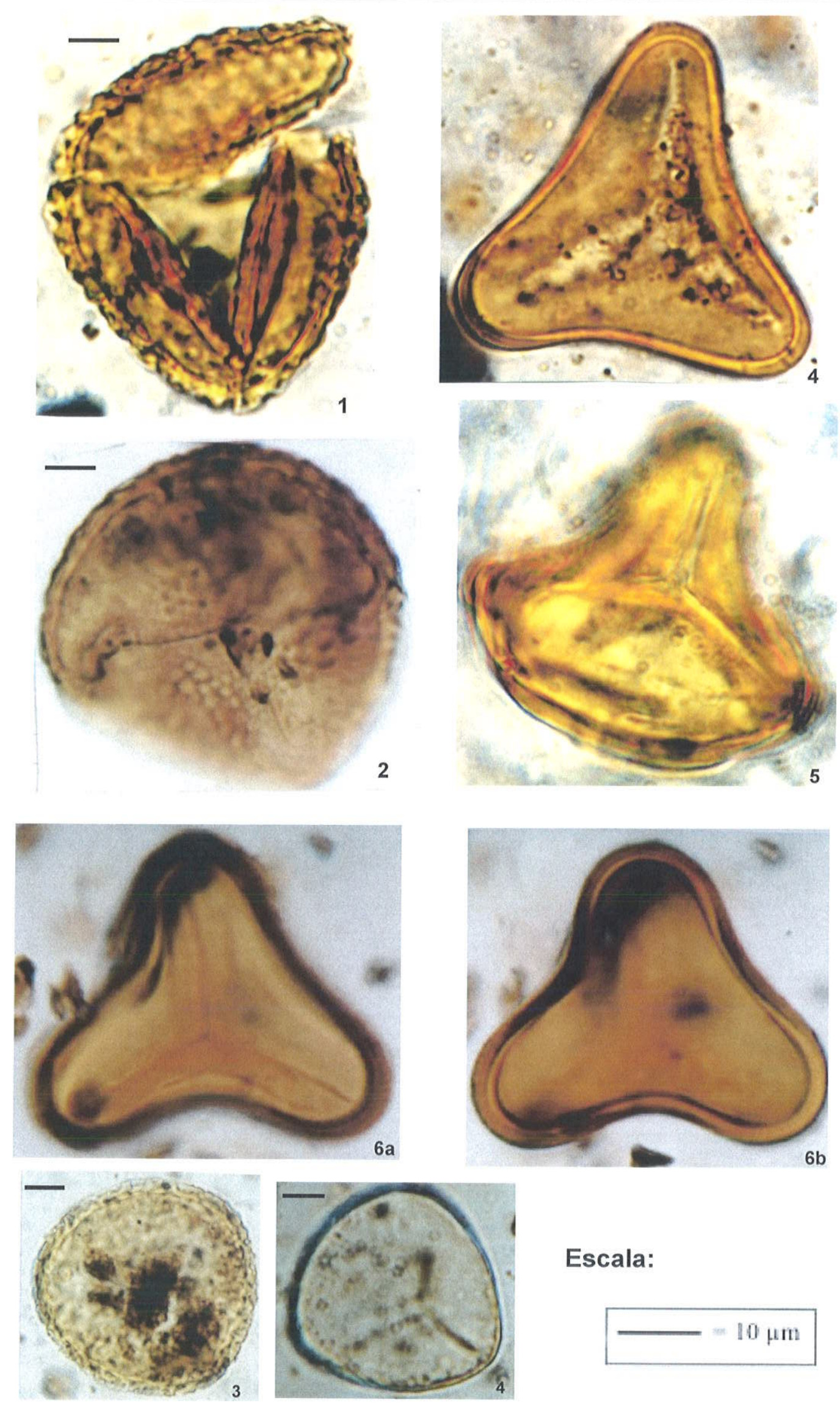

Escala:

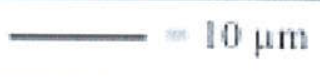

Estampa XII- Família Cyatheaceae- Figura 01 a/b- Cyathea sp Tipo 4; Figura 02 a/b- Cyathea sp Tipo 5; Figura 3 a/b- Cyathea sp Tipo 06; Figura 4 a/b- Cyathea sp Tipo07;Família Dicksoniaceae - Figura 04 a - Dicksonia sp Tipo 01; Figura 05 a- Dicksonia sp Tipo 02; Figura 6 a/b- Dicksonia sp Tipo 03 


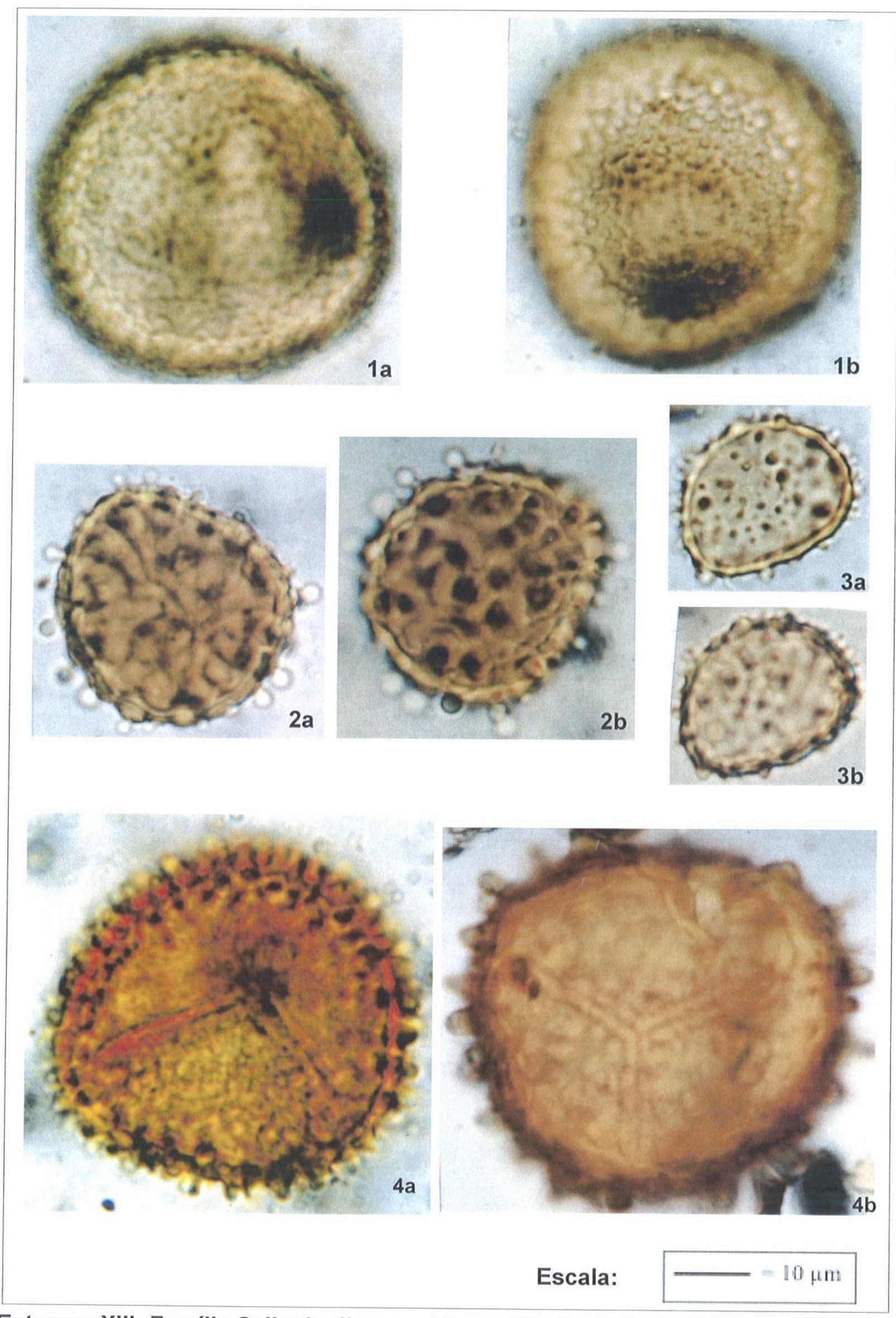

Estampa XIII- Família Sellaginellaceae- Figura 01 a/b- Sellaginella sp Tipo 01; Figura 02 a/b- Sellaginella sp Tipo 02; Figura 3 a/b- Selaginella sp Tipo 03; Figura 4 a/ bSellaginella sp Tipo 04 


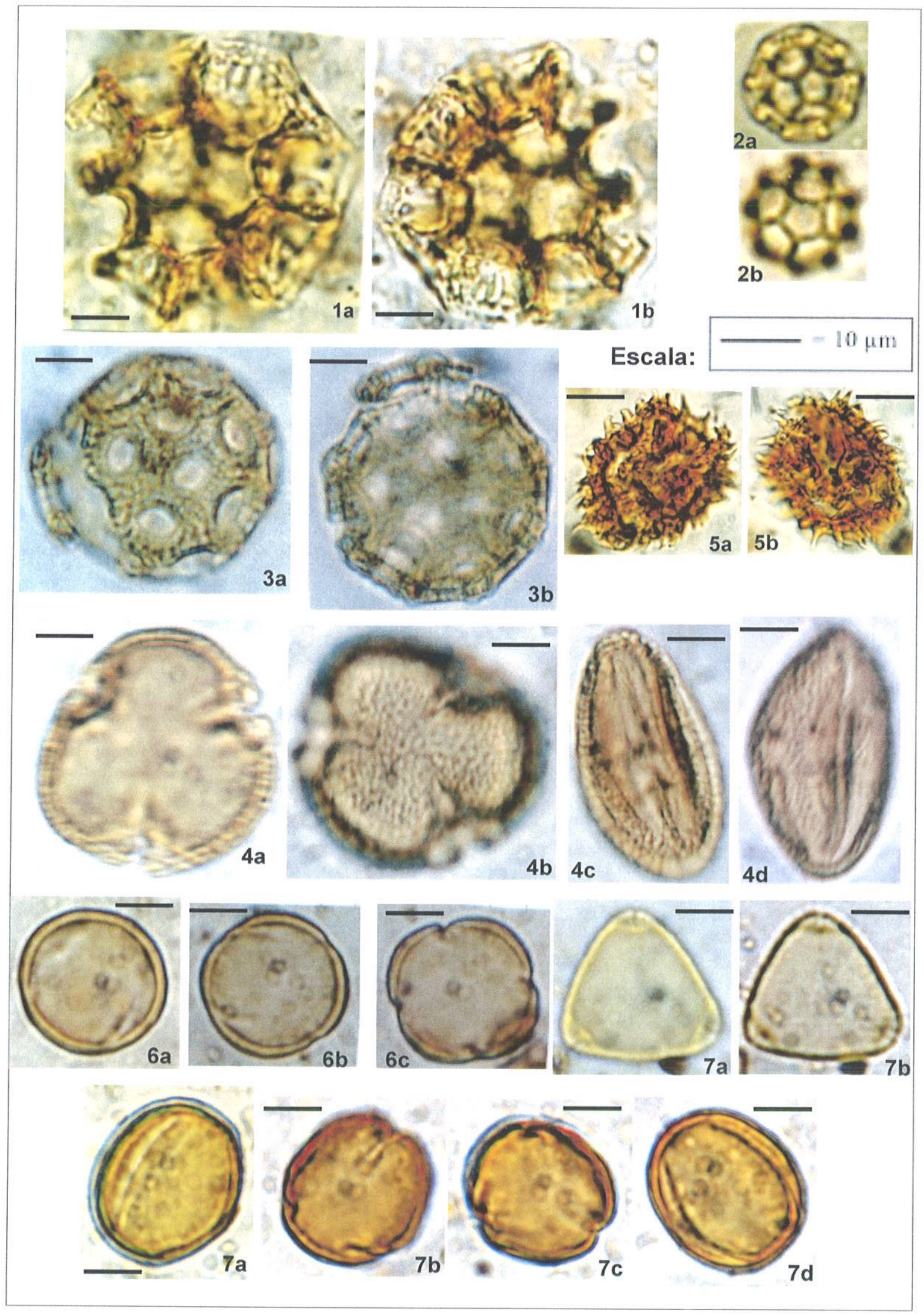

Estampa XIV- Família Amaranthaceae- Figura 1 a/b- Alternanthera sp; Figura 2 a/bPfaffia sp; Figura 3 a/b- Amaranthaceae Tipo 01 aff. Gomphrena sp; Família Anacardiaceae- Figura 4 a/b/c/d- Anacardium sp; Família Asteraceae-Figura 5 a/bVernonia sp Tipo 01;Família Myrsinaceae- Figura 2 a/b/c-Rapanea sp; Família Myrtaceae- Figura 7 a/b- Psidium spTipo 01; Família Begoniaceae-Jacaranda sp 


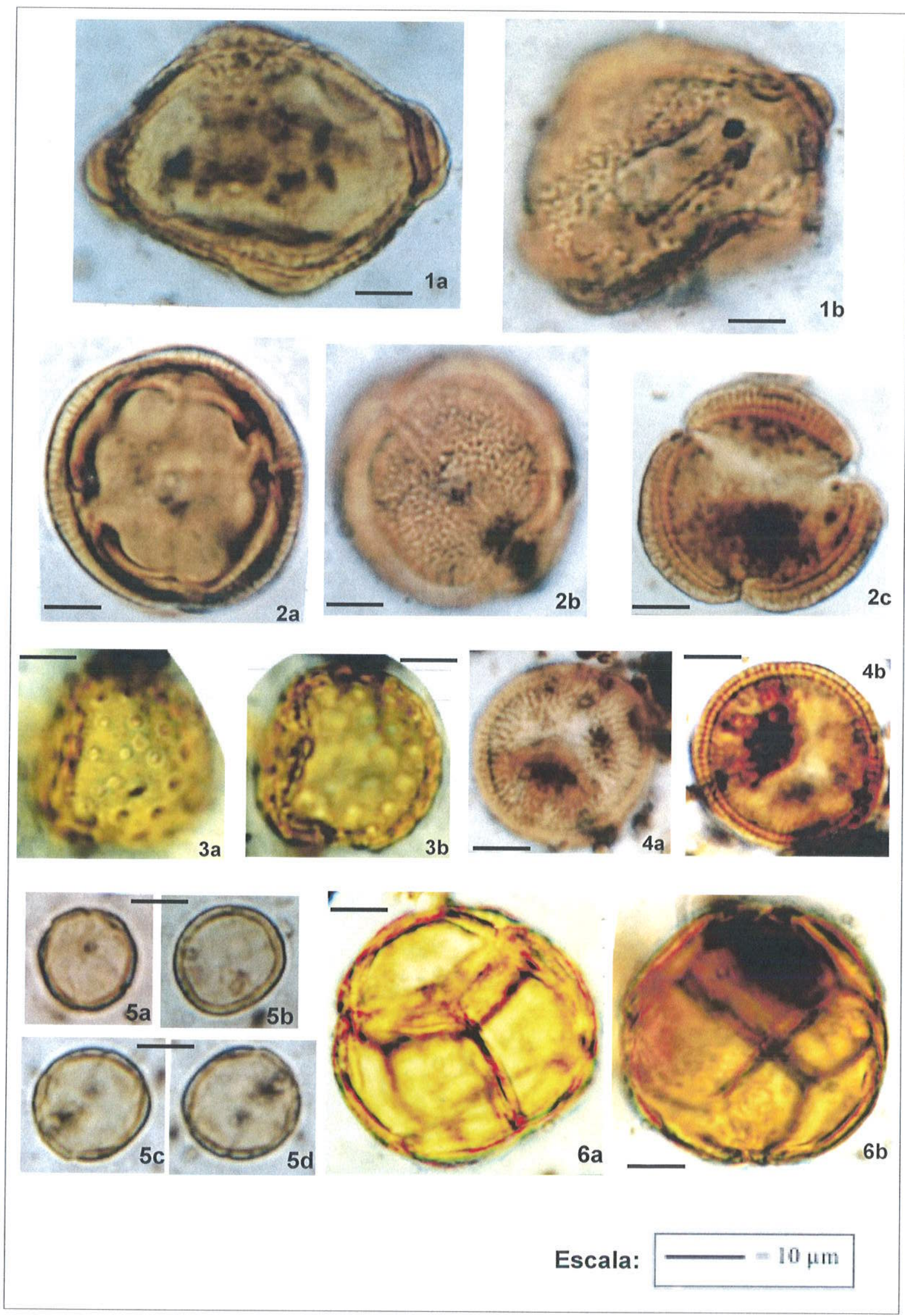

Estampa XV- Família Caryocaraceae- Figura 1 a/b- Caryocar sp; Família Celastraceae- Figura 2 a/b/c- Maytenus sp;Família Chenopodiaceae- Figura 3 a/bChenopodium sp; Família Chloranthaceae- Figura 4 a/b- Hedyosnum sp; Família Cunoniaceae- Figura 5 a/b/c/d- Weinmannia sp; Família Ericaceae- Figura 6 a/bAgarista sp 


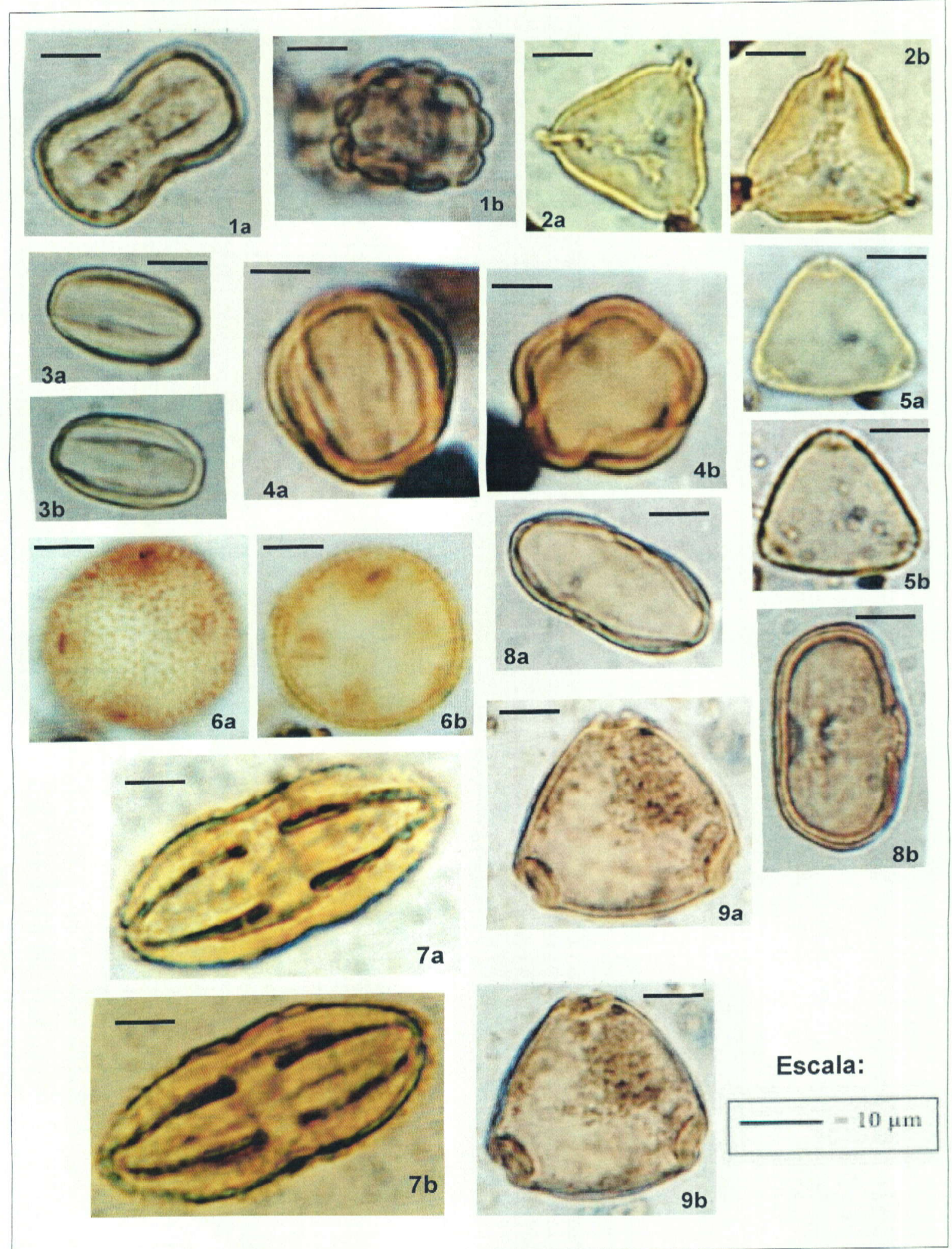

Estampa XVI- Família Lentibulariaceae- Figura 1 a/b- Utricularia sp ; Familia LythraceaeFigura 2 a/b-Cuphea sp; Familia Melastomataceae- Figura 3 a/b- Miconia sp; Figura 4 a/bMelastomataceae indeterminada;Família Myrtaceae- Figura5 a/b- Psidium sp; Família RubiaceaeFigura 6 a/b- Rubiaceae indeterminada;Família Rutaceae- Figura 7a/b-Rutaceae indeterminada; Família Sapotaceae- Figura 8 a/b- Pouteria sp; Família SymplocaceaeFigura 9 a/b - Symplocos sp Tipo 0 


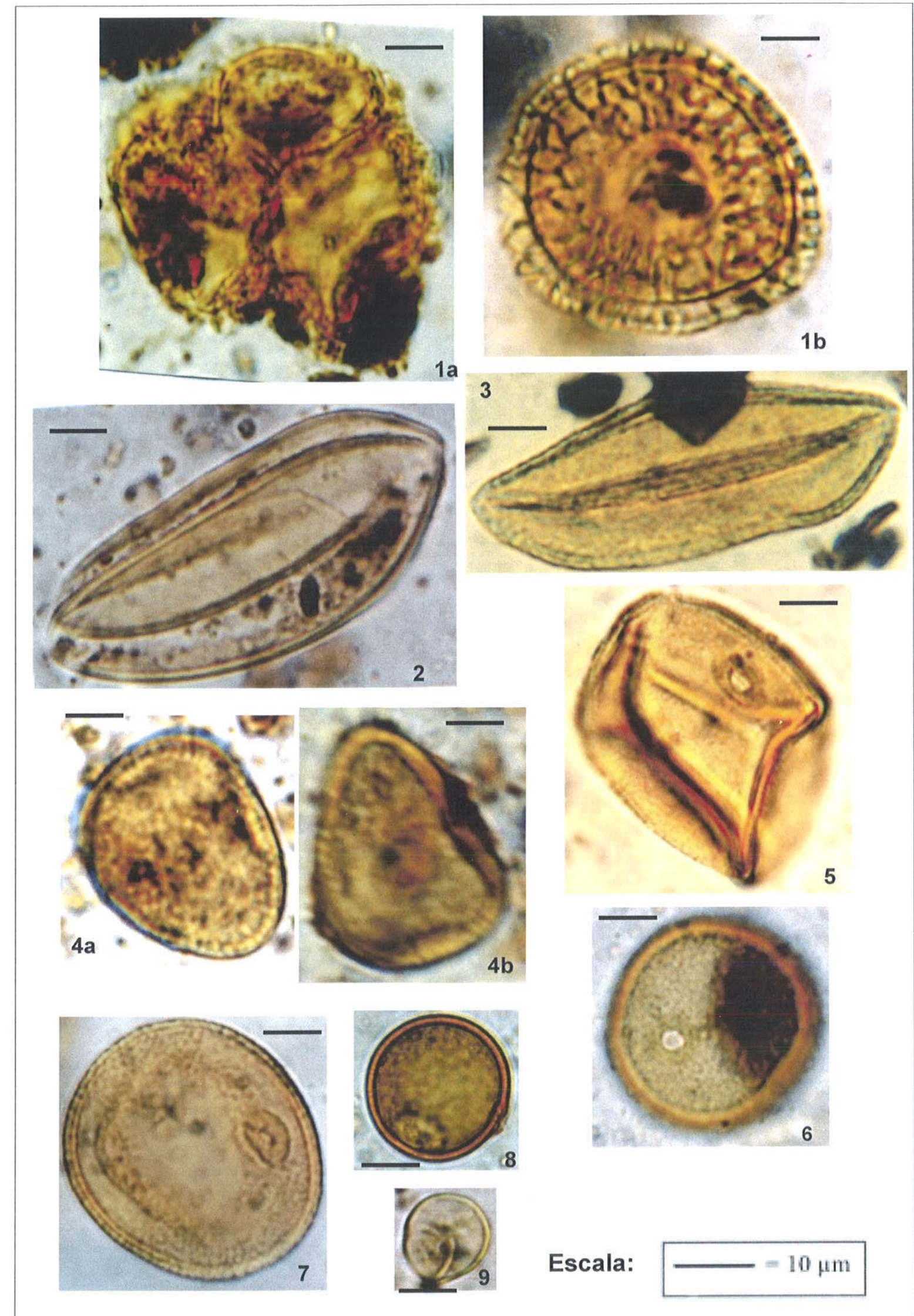

Estampa XVII- Família Winteraceae Figura 1a/b- Drymis sp; Família Arecaceae- Figura 2Acrocomia sp Tipo 02; Figura 3- Acrocomia sp Tipo 03 ; Família Cyperaceae- Cyperus sp; Família Poaceae- Figura 5 -Poaceae Tipo 01 aff. Zea mays; Figura 6- Poaceae Tipo 02; Figura 7- Poaceae Tipo 03 aff. Chusquea; Figura 8- Poaceae Tipo 04; Figura 9- Poaceae Tipo 05 
ANEXO IX

\begin{tabular}{|c|c|c|c|c|c|c|c|c|c|c|c|c|c|c|c|c|}
\hline \multicolumn{9}{|c|}{$\begin{array}{l}\text { Deseja computar os pelíticos (silte/argila) no cálculo dos momentos? Se a resposta for sim, digite "s" na célula em azul (L2); } \\
\text { se for não, digite "n". }\end{array}$} & \multicolumn{8}{|c|}{$s$} \\
\hline \multicolumn{5}{|c|}{$\begin{array}{l}\text { PARAMETROS ESTATISTICOS DA DISTRIBUIÇAO GRANULOMETRICA } \\
\text { (Phi) }\end{array}$} & \multicolumn{11}{|c|}{$\begin{array}{lll}\text { FAIXA GRANULOMÉTRICA }(\%) \\
\end{array}$} & \multirow{3}{*}{$\begin{array}{l}\text { RELAÇÃO FINOI } \\
\text { GROSSO }\end{array}$} \\
\hline CODIGO DA & DIAMETRO & DESVIO & & & & CASCALHO & & & & AREIA & & & & PELITI & $\cos$ & \\
\hline AMOSTRA & MÉDIO & PADRÃO & ASSIMEIRIA & CURTOSE & SEIXOS & GRÂNULOS & TOTAL & MUITO GROSSA & GROSSA & MÉDIA & FINA & MUITO FINA & TOTAL & ARGILA & TOTAL & \\
\hline $0-5 \mathrm{~cm}$ & 5,48 & 2,83 & $-0,33$ & 2,16 & 0,00 & 1,37 & 1,37 & 1,67 & 4,09 & 5,12 & 8,66 & 8,74 & 28,28 & 25,41 & 70,35 & 2,37 \\
\hline $5-10 \mathrm{~cm}$ & 5,95 & 2,51 & $-0,25$ & 2,13 & 0,00 & 0,18 & 0,18 & 0,70 & 1,95 & 2,33 & 6,62 & 12,25 & \begin{tabular}{|l|}
23,85 \\
\end{tabular} & 29,30 & 75,97 & 3,16 \\
\hline $10-15 \mathrm{~cm}$ & 6,20 & 2,48 & $-0,54$ & 2,58 & 0,00 & 0,23 & 0,23 & 0,84 & 2,61 & 2,48 & 4,40 & 6,83 & \begin{tabular}{|l|}
17,16 \\
\end{tabular} & 31,78 & 82,61 & 4,75 \\
\hline $15-20 \mathrm{~cm}$ & 5,46 & 2,83 & $-0,34$ & 2,42 & 0,00 & 2,98 & 2,98 & 1,36 & 2,80 & 3,45 & 7,18 & 12,12 & \begin{tabular}{|l|}
26,91 \\
\end{tabular} & 26,95 & 70,11 & 2,35 \\
\hline $20-25 \mathrm{~cm}$ & 5,06 & 3,27 & $-0,30$ & 1,93 & 0,00 & 4,44 & 4,44 & 3,74 & 6,82 & 5,28 & 7,27 & 10,15 & \begin{tabular}{|l|}
33,25 \\
\end{tabular} & 27,62 & 62,31 & 1,65 \\
\hline $25-30 \mathrm{~cm}$ & 5,74 & 2,59 & $-0,15$ & 2,14 & 0,00 & 0,94 & 0,94 & 0,65 & 1,50 & 2,08 & 7,17 & 14,26 & \begin{tabular}{|l|}
25,67 \\
\end{tabular} & 28,97 & 73,39 & 2,76 \\
\hline $30-35 \mathrm{~cm}$ & 5,78 & 2,62 & $-0,20$ & 1,96 & 0,00 & 0,10 & 0,10 & 0,88 & 1,93 & 4,65 & 9,42 & 8,41 & \begin{tabular}{|l|}
25,28 \\
\end{tabular} & 28,57 & 74,62 & 2,94 \\
\hline $35-40 \mathrm{~cm}$ & 6,50 & 2,35 & $-0,49$ & 2,24 & 0,00 & 0,01 & 0,01 & 0,16 & 1,93 & 1,14 & 5,20 & 8,09 & 16,52 & 36,56 & 83,47 & 5,05 \\
\hline $40-45 \mathrm{~cm}$ & 6,55 & 2,21 & $-0,32$ & 1,99 & 0,00 & 0,01 & 0,01 & 0,17 & 0,37 & 0,70 & 4,31 & 7,94 & 13,48 & 35,78 & 86,51 & 6,41 \\
\hline $45-50 \mathrm{~cm}$ & 6,60 & 2,15 & $-0,42$ & 2,34 & 0,00 & 0,05 & 0,05 & 0,22 & 0,51 & 0,87 & 3,37 & 7,76 & \begin{tabular}{l|}
12,73 \\
\end{tabular} & 34,39 & 87,22 & 6,83 \\
\hline $50-55 \mathrm{~cm}$ & 6,51 & 2,16 & $-0,31$ & 2,11 & 0,00 & 0,02 & 0,02 & 0,20 & 0,44 & 0,64 & 3,48 & 7,97 & 12,74 & 33,04 & 87,24 & 6,84 \\
\hline $55-60 \mathrm{~cm}$ & 6,55 & 1,95 & $-0,30$ & 2,22 & 0,00 & 0,02 & 0,02 & 0,07 & 0,20 & 0,30 & 2,61 & 6,32 & 9,51 & 26,17 & 90,46 & 9,48 \\
\hline $60-65 \mathrm{~cm}$ & 6,45 & 2,22 & $-0,25$ & 2,03 & 0,00 & 0,19 & 0,19 & 0,12 & 0,29 & 0,52 & 4,10 & 8,16 & 13,18 & 34,04 & 86,62 & 6,48 \\
\hline $65-70 \mathrm{~cm}$ & 7,21 & 1,89 & $-0,62$ & 2,34 & 0,00 & 0,00 & 0,00 & 0,04 & 0,11 & 0,15 & 1,47 & 3,81 & 5,58 & 44,48 & 86,47 & 15,49 \\
\hline $70-75 \mathrm{~cm}$ & 6,83 & 2,14 & $-0,46$ & 2,14 & 0,00 & 0,06 & 0,06 & 0,16 & 0,27 & 0,37 & 2,55 & 6,63 & 9,98 & 41,62 & 89,96 & 8,96 \\
\hline $75-80 \mathrm{~cm}$ & 7,33 & 1,94 & $-0,77$ & 2,53 & 0,00 & 0,01 & 0,01 & 0,05 & 0,13 & 0,31 & 1,81 & 3,10 & 5,40 & 50,54 & 94,59 & 17,48 \\
\hline $80-85 \mathrm{~cm}$ & 7,36 & 1,90 & $-0,78$ & 2,47 & 0,00 & 0,01 & 0,01 & 0,04 & 0,11 & 0,19 & 1,04 & 3,89 & 5,27 & 49,65 & 94,72 & 17,93 \\
\hline $85-90 \mathrm{~cm}$ & 6,83 & 2,20 & $-0,51$ & 2,09 & 0,00 & 0,03 & 0,03 & 0,11 & 0,23 & 0,93 & 3,78 & 5,73 & 10,78 & 42,08 & 89,19 & 8,25 \\
\hline $90-95 \mathrm{~cm}$ & 5,38 & 2,75 & 0,08 & 1,63 & 0,00 & 0,02 & 0,02 & 0,03 & 4,26 & 5,41 & 16,04 & 9,06 & 34,80 & 27,55 & 65,18 & 1,87 \\
\hline $95-1,00$ & 6,99 & 2,31 & $-0,69$ & 2,06 & 0,00 & 0,00 & 0,00 & 0,04 & 0,10 & 0,80 & 6,14 & 8,53 & 15,61 & 48,51 & 84,39 & 5,41 \\
\hline $1,00-1,05$ & 7,24 & 2,13 & $-0,88$ & 2,59 & 0,00 & 0,01 & 0,01 & 0,14 & 0,13 & 0,52 & 3,33 & 5,84 & 9,97 & 50,94 & 90,02 & 9,02 \\
\hline $1,05-1,10$ & 6,78 & 2,45 & $-0,57$ & 1,82 & 0,00 & 0,01 & 0,01 & 0,05 & 0,18 & 1,12 & 8,18 & 12,15 & 21,67 & 46,98 & \begin{tabular}{|l|}
78,33 \\
\end{tabular} & 3,61 \\
\hline $1,10-1,15$ & 5,64 & 2,73 & 0,05 & 1,50 & 0,00 & 0,01 & 0,01 & 0,09 & 0,68 & 5,48 & 16,95 & 16,09 & 39,29 & 32,98 & \begin{tabular}{|l|}
60,70 \\
\end{tabular} & 1,54 \\
\hline $1,15-1,20$ & 6,36 & 2,50 & $-0,23$ & 1,52 & 0,00 & 0,01 & 0,01 & 0,04 & 0,13 & 0,93 & 9,95 & 14,98 & 26,03 & 40,18 & \begin{tabular}{|l|}
73,96 \\
\end{tabular} & 2,84 \\
\hline $1,20-1,25$ & 6,13 & 2,71 & $-0,29$ & 1,67 & 0,00 & 0,02 & 0,02 & 0,43 & 1,43 & 2,59 & 13,85 & 11,16 & 29,45 & 39,38 & \begin{tabular}{|l|}
70,52 \\
\end{tabular} & 2,39 \\
\hline $1,25-1,30$ & 5,70 & 2,81 & $-0,13$ & 1,58 & 0,00 & 0,02 & 0,02 & 0,11 & 2,34 & 6,96 & 14,92 & 11,10 & 35,43 & 32,60 & \begin{tabular}{|l|}
64,55 \\
\end{tabular} & 1,82 \\
\hline $1,30-1,35$ & 6,39 & 2,52 & $-0,25$ & 1,58 & 0,00 & 0,04 & 0,04 & 0,12 & 0,26 & 1,48 & 8,69 & 12,00 & 22,55 & 41,84 & 77,41 & 3,43 \\
\hline $1,35-1,40$ & 6,79 & 2,27 & $-0,36$ & 1,65 & 0,00 & 0,00 & 0,00 & 0,06 & 0,14 & 0,42 & 3,54 & 7,09 & 11,25 & 45,65 & \begin{tabular}{|l|}
88,74 \\
\end{tabular} & 7,88 \\
\hline $1,40-1,45$ & 7,24 & 2,14 & $-0,92$ & 2,84 & 0,00 & 0,05 & 0,05 & 0,17 & 0,31 & 0,65 & 3,39 & 5,98 & 10,50 & 51,23 & \begin{tabular}{|l|}
83,61 \\
\end{tabular} & 7,93 \\
\hline $1,45-1,50$ & 7,10 & 2,25 & $-0,70$ & 2,09 & 0,00 & 0,00 & 0,00 & 0,08 & 0,19 & 0,55 & 4,01 & 7,44 & 12,27 & 51,80 & \begin{tabular}{|l|}
87,73 \\
\end{tabular} & 7,15 \\
\hline $1,50-1,55$ & 7,08 & 2,21 & $-0,69$ & 2,05 & 0,00 & 0,01 & 0,01 & 0,06 & 0,11 & 0,25 & 3,61 & 7,21 & 11,24 & 47,91 & \begin{tabular}{|l|}
88,75 \\
\end{tabular} & 7,89 \\
\hline $1,55-1,60$ & 7,14 & 2,23 & $-0,90$ & 2,53 & 0,00 & 0,03 & 0,03 & 0,09 & 0,17 & 0,47 & 5,54 & 10,50 & 16,78 & 48,90 & \begin{tabular}{|l|}
83,20 \\
\end{tabular} & 4,95 \\
\hline $1,60-1,65$ & 6,15 & 2,87 & $-0,34$ & 1,52 & 0,00 & 0,01 & 0,01 & 0,05 & 1,46 & 6,63 & 12,60 & 12,59 & 33,32 & 42,75 & \begin{tabular}{|l|}
66,67 \\
\end{tabular} & 2,00 \\
\hline $1,65-1,70$ & 5,70 & 2,79 & $-0,14$ & 1,62 & 0,00 & 0,03 & 0,03 & 0,09 & 2,44 & 7,27 & 13,74 & 11,44 & 34,98 & 31,69 & \begin{tabular}{|l|}
65,00 \\
\end{tabular} & 1,86 \\
\hline $1,70-1,75$ & 5,87 & 2,77 & $-0,14$ & 1,50 & 0,00 & 0,02 & 0,02 & 0,47 & 0,88 & 4,03 & 16,34 & 15,17 & 36,89 & 35,52 & \begin{tabular}{|l|}
63,09 \\
\end{tabular} & 1,71 \\
\hline $1,75-1,80$ & 24,34 & 3,00 & 3,00 & 2,00 & 0,00 & 0,00 & 0,00 & 0,00 & 0,00 & 0,00 & 0,00 & 0,00 & 0,00 & 48,86 & 100,00 & 1,92 \\
\hline $1,80-1,85$ & 5,99 & 2,61 & $-0,11$ & 1,48 & 0,00 & 0,01 & 0,01 & 0,06 & 0,17 & 2,18 & 15,93 & 14,16 & 32,49 & 34,30 & \begin{tabular}{l|}
67,50 \\
\end{tabular} & 2,08 \\
\hline $1,85-1,90$ & 5,85 & 2,59 & $-0,08$ & 1,56 & 0,00 & 0,01 & 0,01 & 0,07 & 0,41 & 3,26 & 16,14 & 13,44 & 33,33 & 30,01 & 66,66 & 2,00 \\
\hline $1,90-1,95$ & 5,87 & 2,72 & $-0,12$ & 1,47 & 0,00 & 0,00 & 0,00 & 0,04 & 0,54 & 4,60 & 17,80 & 11,51 & 34,50 & 33,94 & 65,50 & 1,90 \\
\hline $1,95-2,00$ & 5,63 & 2,70 & 0,02 & 1,49 & 0,00 & 0,01 & 0,01 & 0,07 & 0,67 & 5,31 & 18,19 & 14,12 & 38,37 & 29,80 & 61,62 & 1,61 \\
\hline $2,00-2,05$ & 5,86 & 2,70 & $-0,08$ & 1,47 & 0,00 & 0,01 & 0,01 & 0,05 & 0,51 & 3,95 & 16,69 & 13,64 & 34,84 & 33,90 & 65,15 & 1,87 \\
\hline $2,05-2,10$ & 6,26 & 2,57 & $-0,28$ & 1,55 & 0,00 & 0,02 & 0,02 & 0,03 & 0,17 & 2,25 & 12,74 & 12,72 & 27,90 & 37,78 & 72,08 & 2,58 \\
\hline $2,10-2,15$ & 6,35 & 2,50 & $-0,29$ & 1,58 & 0,00 & 0,02 & 0,02 & 0,03 & 0,12 & 1,38 & 10,87 & 13,35 & 25,75 & 38,02 & 74,22 & 2,88 \\
\hline $2,15-2,20$ & 6,48 & 2,52 & $-0,34$ & 1,54 & 0,00 & 0,01 & 0,01 & 0,04 & 0,09 & 1,17 & 9,89 & 13,82 & 25,00 & 42,74 & 63,82 & 2,55 \\
\hline $2,20-2,25$ & 6,45 & 2,48 & $-0,32$ & 1,61 & 0,00 & 0,00 & 0,00 & 0,06 & 0,18 & 1,36 & 9,47 & 11,22 & 22,29 & 40,47 & 77,71 & 3,49 \\
\hline
\end{tabular}


ANEXO $X$

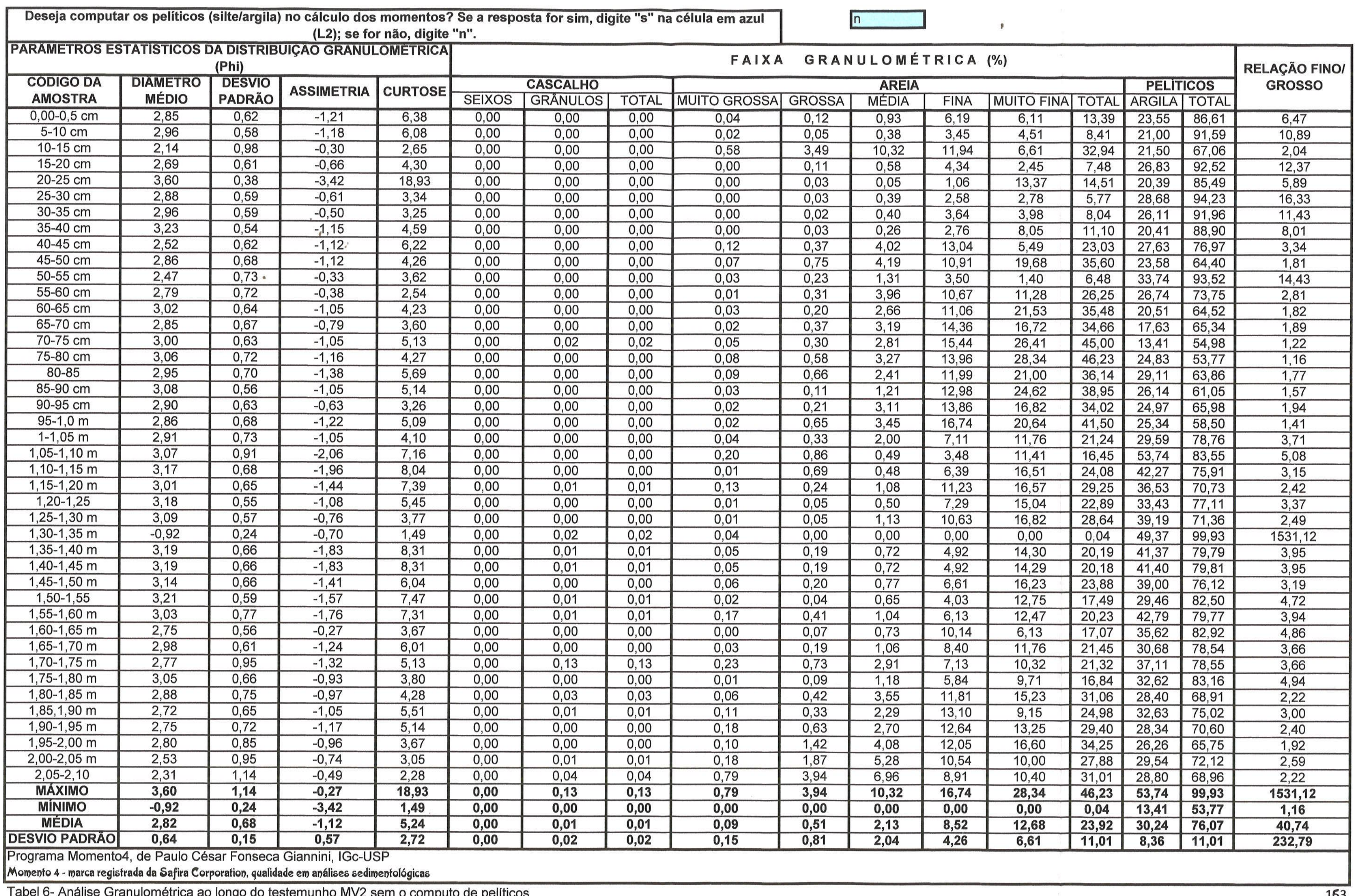


ANEXO XII- Tabela 8- Resultados de quantificação de minerais pesados $(d>2,85)$ ao microscópio petrográfico na classe areia muito fina: MV1

\begin{tabular}{|c|c|c|c|c|c|c|c|c|c|c|c|c|c|c|c|c|c|c|c|c|c|c|c|c|c|c|c|c|}
\hline \multirow{3}{*}{$\frac{\text { CODIGO DA }}{\text { AMOSTRA }}$} & \multicolumn{4}{|c|}{\begin{tabular}{|l|} 
GRUPO DOS MINERAIS \\
OPACOS E SEMI-OPACOS
\end{tabular}} & \multicolumn{16}{|c|}{$\begin{array}{l}\text { GRUPO DOS MINERAIS TRANSPARENTES NÃO MICACEOS: } \\
\text { FREQUENCIAS DE CONTAGEM NO GRUPO (\%) }\end{array}$} & \multicolumn{5}{|l|}{$\theta$} & \multicolumn{3}{|c|}{$\begin{array}{l}\text { INDICES DE } \\
\text { MATURIDADE }\end{array}$} \\
\hline & \multicolumn{4}{|c|}{\begin{tabular}{|c|} 
FREQÜENCIASDE \\
CONTAGEM NO ENSAIO (\%)
\end{tabular}} & & & & & & & & & & & & & & & & & & & & & \multirow{2}{*}{$\begin{array}{l}\text { TOTAL } \\
\text { NO } \\
\text { ENSAIO }\end{array}$} & \multicolumn{3}{|c|}{ QUIMICA } \\
\hline & OPAC & IEUC & LIMO & \begin{tabular}{|l|l|} 
TOTAL \\
\end{tabular} & ZIRC & TURM & RUTT & ANAT & EPID & $\mathrm{ZOIS}$ & DATI & PERO & TITA & SILL & CIAN & ESTA & GRAN & HORN & TREM & HIPE & TDIOP & AUGI & ALTE & TOTAL & & \begin{tabular}{|l|l|} 
IZTR \\
\end{tabular} & IMET & ilNS \\
\hline 5 & 51,0 & 4,0 & 14,0 & 69,0 & 42,7 & 3,6 & 1,8 & 0,0 & \begin{tabular}{|l|}
26,4 \\
\end{tabular} & 0,9 & 1,8 & 0,0 & 0,9 & 3,6 & 0, & 0,0 & & 14,5 & 0,0 & 0,9 & 0 & 0,0 & & & 42 & 48,2 & $\mid 34,5$ & 17,3 \\
\hline 10 & 29,0 & 7,0 & 53,0 & 89,0 & 35,2 & 1,9 & 0,4 & 0,0 & 25,3 & 0,0 & 0,0 & 0,0 & 0,0 & \begin{tabular}{|l|}
4,6 \\
\end{tabular} & 0,4 & 0,0 & 1,1 & 8,8 & 0,0 & 0,8 & 0,0 & 0,0 & 21,5 & 100 & 58 & 37,5 & \begin{tabular}{|l|}
31,4 \\
\end{tabular} & 31,0 \\
\hline 15 & 36,0 & 0,0 & 22,0 & 58,0 & 31,2 & 37 & 0,9 & 0,0 & 34,9 & 0,0 & 0,9 & 0,0 & 0,0 & 3,7 & 0,0 & 0,0 & 0,9 & 22,0 & 00 & 0,9 & 0,0 & 0,0 & 0,9 & 100 & 53 & 35,8 & 40,4 & 23,9 \\
\hline 20 & 45,0 & 2,0 & 22,0 & 69,0 & 57,8 & 2,8 & 2,8 & 0,0 & 28,4 & 0,0 & 0,0 & 0,0 & \begin{tabular}{|l|}
0,9 \\
\end{tabular} & 1,8 & 0,0 & 0,0 & 0,0 & 4,6 & 0,0 & 0,9 & 0,0 & 0,0 & 0,0 & 00 & 45 & 63,3 & $\mid$\begin{tabular}{|l|}
31,2 \\
\end{tabular} & 5,5 \\
\hline 25 & 57,0 & 1,0 & \begin{tabular}{|l|}
12,0 \\
\end{tabular} & 70,0 & \begin{tabular}{|l|}
37,5 \\
\end{tabular} & 1,0 & 0,0 & 1,0 & \begin{tabular}{|l|}
39,4 \\
\end{tabular} & 0,0 & 1,0 & 0,0 & 0 & 1,9 & 1,0 & 0,0 & 2,9 & 10,6 & 0,0 & 1,0 & 0,0 & 0,0 & 2,9 & 100 & 38 & 38,8 & 46,6 & 14,6 \\
\hline 30 & 67,0 & 2,0 & 9,0 & 78,0 & 46,6 & 0,9 & 2,6 & 0,0 & 30,2 & 0,0 & 0,9 & 0,0 & 0,0 & \begin{tabular}{|l|}
0,0 \\
\end{tabular} & 0,0 & 0,9 & 3,4 & 9,5 & 0,0 & 0,9 & 0,0 & 0,0 & 4,3 & 00 & 30 & 50,0 & 35,3 & 14,7 \\
\hline 35 & 24,0 & 4,0 & 15,0 & 43,0 & 43,8 & 3,6 & 0,0 & 0,0 & 33,0 & 0,0 & $\begin{array}{l}1,8 \\
\end{array}$ & 0,0 & \begin{tabular}{|l|}
0,9 \\
\end{tabular} & \begin{tabular}{|l|}
4,5 \\
\end{tabular} & 0,0 & 0,0 & 0,9 & 8,0 & 0,0 & 0,0 & 0,0 & 0,0 & $\frac{7,6}{3,6}$ & 100 & 65 & 47,3 & $\frac{1,1}{41,1}$ & $\frac{11,6}{11,6}$ \\
\hline 40 & 33,0 & 3,0 & 3,0 & $39,0_{7}$ & \begin{tabular}{|l|}
23,8 \\
\end{tabular} & 0,8 & 0,0 & 0,0 & 62,3 & 0,0 & 0,0 & 0,0 & 1,5 & \begin{tabular}{|l|}
3,1 \\
\end{tabular} & 0,0 & 0,0 & 0,0 & 6,2 & 0,0 & 0,8 & 0,0 & 0,0 & 1,5 & 100 & 64 & 24,6 & 66,9 & 8,5 \\
\hline 45 & 29,0 & 7,0 & 4,0 & 40,0 & 6,2 & 2,3 & 3,8 & 0,0 & \begin{tabular}{|l|}
69,2 \\
\end{tabular} & 0,0 & 0,0 & 0,0 & 0,0 & \begin{tabular}{|l|}
2,3 \\
\end{tabular} & 0,0 & 0,0 & 0,8 & 12,3 & 0,0 & 0,0 & 0,0 & 0,0 & 3,1 & 50 & 65 & 12,3 & 72,3 & 15,4 \\
\hline 50 & 60,0 & 12,0 & 4,0 & 76,0 & 4,6 & 2,0 & 1,3 & 0,7 & 62,7 & 0,0 & 0,0 & 0,0 & 0,7 & \begin{tabular}{|l|}
0,0 \\
\end{tabular} & 0,0 & 0,0 & 0,0 & 11,1 & 0, & 0,0 & 0,0 & 0,0 & 17,0 & 100 & 36 & 7,9 & 63,8 & 28,3 \\
\hline 55 & 39,0 & 4,0 & 9,0 & 52,0 & \begin{tabular}{|l}
24,5 \\
\end{tabular} & 0,6 & 0,0 & 0,0 & 51,6 & 0,0 & \begin{tabular}{|l|}
0,0 \\
\end{tabular} & 0,0 & 0,0 & \begin{tabular}{|l|}
0,6 \\
\end{tabular} & 0,0 & 0,0 & 0,0 & 11,6 & 0,0 & 0,0 & 0,0 & 0,0 & 11,0 & 10 & 56 & 25,2 & 52,3 & 22,6 \\
\hline 60 & 24,0 & 17,0 & 5,0 & 46,0 & 1,3 & 1,3 & 0,0 & 0,0 & 66,5 & 0,0 & \begin{tabular}{|l|}
0,0 \\
\end{tabular} & 0,0 & 0,6 & \begin{tabular}{|l|}
0,6 \\
\end{tabular} & 0,0 & \begin{tabular}{|l|l|}
0,0 \\
\end{tabular} & 1,3 & 13,9 & 0,0 & 0,6 & 0,0 & 0,0 & 13,9 & 1 & 67 & 2,5 & 69,0 & 28,5 \\
\hline 65 & 35,0 & 6,0 & 1,0 & 42,0 & 21,8 & 2,0 & 0,0 & 0,7 & 57,8 & 0,0 & \begin{tabular}{|l|}
0,0 \\
\end{tabular} & \begin{tabular}{|l|}
0,7 \\
\end{tabular} & 0,0 & \begin{tabular}{|l|}
0,7 \\
\end{tabular} & 0,0 & 0,0 & 0,7 & 6,1 & 0 & 0,0 & 0,0 & 0,0 & 9,5 & & 62 & 24,0 & 60,3 & 15,8 \\
\hline 70 & 21,0 & 18,0 & 2,0 & 41,0 & 6,7 & 0,7 & 0,0 & 0,0 & 75,3 & 0,0 & 0,0 & 0,0 & 0,0 & \begin{tabular}{|l|}
2,7 \\
\end{tabular} & 0,0 & 0,0 & 0,7 & 5,3 & 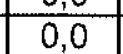 & 0,7 & 0,0 & 0,0 & $\frac{1,2}{8,0}$ & & 70 & 7,3 & \begin{tabular}{|l|}
78,7 \\
\end{tabular} & 14,0 \\
\hline 75 & 26,0 & 11,0 & 6,0 & 43,0 & 9,4 & 0,6 & 0,0 & 0,0 & 71,8 & 0,0 & \begin{tabular}{|l|}
0,6 \\
\end{tabular} & \begin{tabular}{|l|}
0,0 \\
\end{tabular} & 0,0 & \begin{tabular}{|l|}
1,7 \\
\end{tabular} & 0,0 & 0,0 & 0,0 & 5,0 & 0, & 0,0 & 0,6 & 0,6 & 9,4 & & 68 & 9,9 & 74,0 & 16,0 \\
\hline 80 & 34,0 & 11,0 & 4,0 & 49,0 & \begin{tabular}{|l}
6,5 \\
\end{tabular} & 0,8 & 0,8 & 0,0 & 65,4 & 0,0 & 0,0 & \begin{tabular}{|l|}
0,0 \\
\end{tabular} & 0,8 & 1,6 & 0,8 & 0,0 & 1,6 & 4,7 & 0, & 0,0 & 0,0 & 0,0 & 7,1 & & 59 & 18,1 & 70,1 & 11,8 \\
\hline 85 & 19,0 & 7,0 & 3,0 & 29,0 & 15,1 & 0,0 & 0,7 & 0,0 & 71,2 & 0,0 & 0,0 & 0,0 & 0,7 & 0,7 & 0,0 & 0,0 & 0,0 & 6,5 & 0 & 0,0 & 0,0 & 0,0 & 5,0 & 11 & 76 & 15,8 & 72,7 & 11,5 \\
\hline 90 & 23,0 & 5,0 & 3,0 & 31,0 & 27,2 & 1,5 & 2,2 & 0,0 & 58,1 & 0,0 & 0,0 & 0,0 & 0,0 & \begin{tabular}{|l|}
0,7 \\
\end{tabular} & 0,0 & 0,0 & 0,0 & 5,1 & 0 & 0,0 & 0,0 & 0,0 & 5,1 & 10 & 73 & 30,9 & 58,8 & 10,3 \\
\hline 95 & 15,0 & 9,0 & 5,0 & 29,0 & 49,2 & 0,8 & 0,8 & 0,0 & 36,7 & 0,0 & 0,0 & 0,0 & 0,8 & 2,3 & 0 & 0,0 & 0,0 & 5,5 & 0 & 0,0 & 0,0 & 0,0 & 3,9 & 10 & 77 & 50,8 & 39,8 & 9,4 \\
\hline 100 & 52,0 & 7,0 & 1,0 & 60,0 & 29,8 & 0,8 & 0,0 & 0,0 & 47,9 & 0,0 & \begin{tabular}{|l|}
0,0 \\
\end{tabular} & 0,0 & 0,8 & 0,8 & 0, & 0,0 & 0,0 & 6,6 & 0, & 0,0 & 0,0 & 0,0 & 13,2 & 1 & 45 & 30,6 & 49,6 & 19,8 \\
\hline 105 & 9,0 & 0,0 & 1,0 & 10,0 & 9,9 & 0,8 & 0,0 & 0,0 & 57,3 & \begin{tabular}{|l|}
0,0 \\
\end{tabular} & 0,0 & 0,8 & 0,8 & 0,8 & 0 & 0,0 & 0,0 & 27,5 & 0 & & 0,0 & 0,0 & 2,3 & & 90 & $\mid$ & \begin{tabular}{|l|}
59,5 \\
59,
\end{tabular} & 29,8 \\
\hline 110 & 25,0 & 1,0 & 0,0 & 26,0 & 11,2 & 1,4 & \begin{tabular}{|l|}
0,7 \\
\end{tabular} & 0,0 & 51,7 & \begin{tabular}{|l|}
0,0 \\
\end{tabular} & \begin{tabular}{|l|l}
0,0 \\
\end{tabular} & 0,0 & 0,0 & 0,7 & 0 & 0,0 & 0,0 & 32,9 & 0 & 0,0 & 0,0 & 0,0 & 1,4 & 1 & 74 & 13,3 & 52,4 & 34,3 \\
\hline 115 & 57,0 & 3,0 & 0,0 & 60,0 & \begin{tabular}{|l}
16,7 \\
\end{tabular} & 0,7 & 0,7 & 0,0 & 47,3 & \begin{tabular}{|l|}
0,0 \\
\end{tabular} & \begin{tabular}{|l|}
0,0 \\
\end{tabular} & 0,0 & 0,7 & 0,7 & 0, & 0,0 & 0,0 & 13,3 & 0 & 0,0 & 0,0 & 0,0 & 20,0 & & 42 & 18,0 & 48,7 & 33,3 \\
\hline 120 & 52,0 & 2,0 & $\overline{1,4}$ & 55,0 & 4,0 & 1,3 & 0,0 & 0,0 & 62,0 & \begin{tabular}{|l|}
0,0 \\
\end{tabular} & 0,0 & 0,0 & 0,7 & 0,7 & 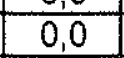 & 0,0 & 0,0 & 13,3 & 0 & 0. & 0,0 & 0,0 & 18,0 & & 47 & 5,3 & $\mid$\begin{tabular}{|l|}
$\mid 63,3$ \\
\end{tabular} & 31,3 \\
\hline 1 & 41,0 & 1,0 & 0 & 42,0 & 7,0 & 1,2 & \begin{tabular}{|l|}
0,0 \\
\end{tabular} & 0,0 & 69,2 & 0,0 & 0,0 & 0,0 & 1,2 & 0,6 & 0 & 0,0 & 0,0 & 12,8 & 0 & 0,0 & 0,0 & 0,0 & 8,1 & & 59 & 8,1 & $|70,9|$ & 20,9 \\
\hline 13 & 20,0 & 1,0 & 1,0 & 22,0 & 4,3 & 0. & 0,0 & 0,0 & 68,1 & 0,0 & 0,0 & 0,0 & 1,2 & 0, & & 0,0 & 0,0 & 24,1 & 0, & 0 & 0,0 & 0,0 & 1,2 & 1 & 79 & 4,7 & 70,0 & 25,3 \\
\hline 1 & 1,0 & 1,0 & 2 & 4,0 & 9,3 & 0,6 & 0,3 & 0,0 & 79,0 & \begin{tabular}{|l|}
0,0 \\
\end{tabular} & 0,0 & 0,0 & 1,1 & 0,6 & 0, & 0,0 & 0,0 & 5,1 & 0 & 0 & 0,0 & 0,0 & 4,0 & & 98 & 10,2 & \begin{tabular}{|l|}
80,7 \\
\end{tabular} & 9,1 \\
\hline 1 & 1,0 & 3,0 & 1, & 5,0 & 4,3 & 0,5 & 0,5 & 0,0 & 75,4 & \begin{tabular}{|l|}
0,0 \\
\end{tabular} & 0,0 & 0,0 & 4,3 & 1,4 & 0, & 0,0 & 0,0 & 4,8 & 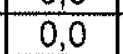 & 0 & 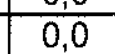 & 0,0 & 8,7 & & 97 & 5,3 & \begin{tabular}{|l|}
81,2 \\
\end{tabular} & $\frac{11}{13,5}$ \\
\hline 145 & 13,0 & 2,0 & 0 & 15,0 & 5,2 & 0,0 & 0 & 0,0 & 70 & \begin{tabular}{|l|}
0,0 \\
\end{tabular} & 0,0 & 0,0 & 3,1 & \begin{tabular}{|l|}
$T_{1}$ \\
\end{tabular} & 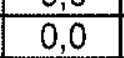 & 0,0 & 0 & 17,9 & 0 & 0 & 0,0 & 0,0 & $\frac{2,1}{2,2}$ & & 86 & 5,2 & \begin{tabular}{|l|}
74,7 \\
\end{tabular} & 20,1 \\
\hline & 14,0 & 1,0 & 1. & 16,0 & 4,8 & 0,4 & 0 & 0,0 & \begin{tabular}{|l|}
$71,9,9$ \\
\end{tabular} & \begin{tabular}{|l|}
0,0 \\
\end{tabular} & 0,0 & 0,0 & 0,4 & $\frac{1,}{1,}$ & 0 & 0,0 & 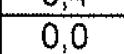 & 18,0 & $\frac{\pi}{0}$ & 0 & 0,0 & 0,0 & $\frac{1, k}{2,2}$ & & 85 & $\frac{1,2}{5,7}$ & \begin{tabular}{|l|}
$\mid 74,1$ \\
44,1
\end{tabular} & $\frac{0,11}{20,2}$ \\
\hline 155 & 8,0 & 6,0 & 0, & 14,0 & 35,6 & 0 & 0 & 0,0 & 40,8 & \begin{tabular}{|l|}
0,0 \\
\end{tabular} & 0,5 & 0,0 & 5 & 3,7 & 0 & 0,0 & 0,0 & 1,0 & 0 & 0 & 0 & 0,0 & 12,0 & & 89 & 36,6 & $\mid 50,3$ & $\frac{1,2}{13,1}$ \\
\hline & 1,0 & 7,0 & 1 & 9 & 11,6 & 1, & 0 & 0,0 & 71,7 & \begin{tabular}{|l|}
0,0 \\
\end{tabular} & 0,0 & 0,0 & n & 2,4 & & 0,0 & 0 & 3,6 & 0 & 0 & 0,0 & 0,0 & 8,0 & & 96 & 13,5 & \begin{tabular}{|l|}
74,9 \\
\end{tabular} & 11,6 \\
\hline 165 & 18,0 & 2,0 & 2,0 & 22,0 & 20,4 & 0,5 & 0, & 0,0 & 68,4 & 0,0 & 0,0 & 0,0 & 0 & 1 & 0 & 0,0 & 0 & 1,5 & 0 & 0 & 0,0 & 0,0 & 7,1 & & 80 & 20,9 & 70,4 & 87 \\
\hline 1 & 20,0 & 3,6 & 2, & 25,0 & 21,1 & & 0 & 0 & 56,3 & 0,0 & 0,0 & 0,0 & 0 & 1, & 0 & 0,0 & 0 & 7,2 & 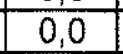 & 0 & - & 0,0 & 11,8 & & 79 & 22,9 & 58,1 & 19,0 \\
\hline 175 & 29,0 & 3,0 & 1, & 33,0 & 26,9 & 1,1 & 0, & 0,0 & 61,1 & \begin{tabular}{|l|}
0,0 \\
\end{tabular} & 0,0 & 0,0 & 0, & 0 & 0 & 0,0 & 0 & 7,1 & 0 & 0 & 0,0 & 0,0 & 2,8 & & 70 & 28,3 & \begin{tabular}{|l|}
61,8 \\
\end{tabular} & 9,9 \\
\hline 180 & 41,0 & 3,6 & 1, & & 40,2 & 0,8 & 0 & 0 & 46,2 & 0,0 & 0,0 & 0 & 0 & 0 & & 0,0 & & 85 & 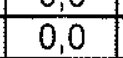 & $\frac{\pi}{n}$ & & $\frac{1,0}{0,0}$ & 3,4 & & 57 & \begin{tabular}{|l|l|} 
& 41,0 \\
\end{tabular} & \begin{tabular}{|l|}
47,0 \\
4
\end{tabular} & $\frac{1,0}{12,0}$ \\
\hline 18 & 6,0 & 4, & 2 , & & 36,6 & 0,6 & 0,6 & 0 & 42,2 & 0,0 & 1,2 & 0,0 & 1,9 & 0,6 & 0 & 0,0 & 0 & 10,6 & 0 & 0 & 0,0 & 0,0 & 5,6 & & 91 & \begin{tabular}{|l|l|}
37,9 \\
\end{tabular} & $|46,0|$ & $\frac{12,1}{16,1}$ \\
\hline 190 & 21,0 & 1,0 & 1 & 23,0 & 0,6 & 1 & 0 , & 0 & 67,1 & \begin{tabular}{|l|}
0,0 \\
\end{tabular} & 0,0 & 0, & 0 & 0 & 0 & 0,0 & 0 & 27,7 & 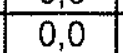 & 0 & & 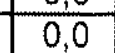 & 2 & & 79 & 2,0 & $\mid$\begin{tabular}{|c|}
$\mid 67,9$ \\
$\mid$
\end{tabular} & $\frac{10,1}{30,0}$ \\
\hline & 15,0 & 2,0 & 2 & 19,0 & 24,1 & 0,1 & 0,2 & 0,0 & 49,8 & \begin{tabular}{|l|}
0,0 \\
\end{tabular} & 0,0 & 0,0 & 2, & 0 & 0 & 0,0 & 0,0 & 22,1 & 0 & 0 & 0,0 & 0,0 & 0,2 & & 84 & 25,0 & \begin{tabular}{|l|}
52,7 \\
\end{tabular} & 22,3 \\
\hline 200 & 14,0 & 3,0 & 10 & 18,0 & $\begin{array}{l}28,1 \\
28,8\end{array}$ & 1,8 & 0,6 & 0,0 & 48,2 & \begin{tabular}{|l|}
0,0 \\
\end{tabular} & 0,0 & 0,0 & 0 & 0 & & & & 1. & 0 & 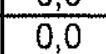 & 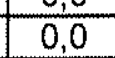 & 0,0 & 4,7 & & 84 & \begin{tabular}{|l}
1,2 \\
\end{tabular} & \begin{tabular}{|l|}
49,4 \\
\end{tabular} & 19,4 \\
\hline 205 & 0 & $\frac{\pi, 0}{2,0}$ & 1, & & 40,4 & $\frac{11}{10}$ & $\frac{1,5}{0,5}$ & 0,0 & 35,5 & \begin{tabular}{|l|}
0,0 \\
\end{tabular} & 0,0 & 0, & $\frac{\sqrt{2}}{2}$ & $\frac{1}{1 .}$ & 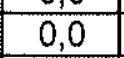 & 0,0 & 0,0 & 15,8 & 0 & 0 & 0,0 & 0,0 & 3 & & 59 & \begin{tabular}{|l}
41,5 \\
\end{tabular} & \begin{tabular}{|l|}
39,7 \\
39,
\end{tabular} & $\frac{19,1}{19,1}$ \\
\hline 210 & 39,0 & 4,0 & 3, & 46,0 & 37,3 & 0,7 & 0,7 & 0,0 & 39,4 & \begin{tabular}{|l|}
0,0 \\
\end{tabular} & 0,0 & 0,0 & 0,7 & 1. & 0 & 0,0 & 0,0 & 16,2 & 0, & 0 & 0,0 & 0,0 & 3,5 & & 58 & \begin{tabular}{|l|l}
18,7 \\
\end{tabular} & $|4|, \mid$ & 19,7 \\
\hline & 27,0 & 4, & $\frac{1}{2,}$ & & 54,7 & $\frac{1}{0}$ & 0,6 & 0,0 & 25,0 & $|0,0|$ & 0,0 & 0,0 & 0 & 1 & & 0 & & 12,8 & 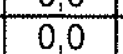 & 0 & 0,0 & 0,0 & 4,1 & & 71 & \begin{tabular}{|l}
55,8 \\
\end{tabular} & \begin{tabular}{|l|}
41,0 \\
27,3
\end{tabular} & $\frac{1,1}{16,9}$ \\
\hline 220 & 28,0 & 4,0 & 2,0 & 34,0 & 21,0 & 4 & 0,0 & 0,0 & 58,0 & \begin{tabular}{|l|}
0,0 \\
\end{tabular} & 0,0 & 0,0 & 1,7 & 0 & 0 & 0,0 & 0,0 & 10,1 & $\frac{1}{0,1}$ & 0 & 0,0 & 0,0 & 4,2 & 10 & 69 & 25,2 & \begin{tabular}{|l|}
$\mid 60,5$ \\
60,
\end{tabular} & 14,3 \\
\hline 225 & 28,0 & 6,0 & 3,0 & 37,0 & 34,7 & 5,6 & 0,7 & 0,0 & 45,8 & \begin{tabular}{|l|}
0,0 \\
\end{tabular} & 0,0 & 0, & 0,0 & 0, & 0 & 0,0 & 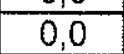 & 2,8 & 0 & $\frac{\pi}{0}$ & 0,0 & 0 & 9,7 & & 68 & 41,0 & \begin{tabular}{|l|}
46,5 \\
\end{tabular} & 12,5 \\
\hline 232 & 26,0 & 2,0 & \begin{tabular}{|l|}
4,0 \\
\end{tabular} & 32,0 & 24,0 & 0,7 & 0,7 & 0,0 & 62,7 & \begin{tabular}{|l|}
0,0 \\
\end{tabular} & 0,0 & 0,0 & 2,7 & 1 & 0,0 & 0,0 & 0 & 4,0 & 0, & 0 & 0,0 & 0,0 & 4,0 & 1 & 71 & 25,3 & \begin{tabular}{|l|}
66,7 \\
\end{tabular} & 8,0 \\
\hline MÁXIM & 67,0 & 18,0 & \begin{tabular}{|l|}
53,0 \\
\end{tabular} & 89,0 & 57,8 & 5,6 & 3,8 & 1,0 & 79,0 & \begin{tabular}{|l|}
0,9 \\
\end{tabular} & 1,8 & 0,8 & 5,2 & 4 & 1 & 0.9 & 3 & 32,9 & 0 & 1 & & & 21,5 & & 98,2 & 63,3 & \begin{tabular}{|l|}
81,2 \\
\end{tabular} & 34,3 \\
\hline$M$ & 1,0 & 0,0 & 0,0 & 4,0 & 0,6 & 0,0 & 0,0 & 0,0 & 25,0 & \begin{tabular}{|l|}
0,0 \\
\end{tabular} & 0,0 & 0,0 & 0,0 & 0,0 & $U_{1}$ & 0,0 & 0,0 & 1,0 & 0,1 & 0 & 0,0 & 0,0 & 0,0 & 10 & 30,1 & 2,0 & \begin{tabular}{|l|}
27,3 \\
\end{tabular} & \begin{tabular}{|l|}
5,5 \\
\end{tabular} \\
\hline MÉDIA & 28,5 & 4,5 & \begin{tabular}{|l|}
5,0 \\
\end{tabular} & 38,1 & 23,2 & 1,3 & 0,6 & 0,0 & 54,0 & \begin{tabular}{|l|}
0,0 \\
\end{tabular} & 0,2 & 0,0 & 0,9 & 1,4 & 0,0 & 0,0 & 0,3 & 11,2 & 0,0 & 0,2 & 0,0 & 0 & 6,5 & 100 & $\frac{1,1}{67,6}$ & $\frac{2,0}{25,1}$ & $\mid$\begin{tabular}{|l|}
$\mid 2,1$ \\
57,1
\end{tabular} & 17.8 \\
\hline SVIO PADR & 16,1 & 4,0 & 8,8 & 20,4 & 15,4 & 1,2 & 0,8 & 0,2 & 15,4 & \begin{tabular}{|l|}
0,1 \\
\end{tabular} & 0,5 & 0,1 & 1,1 & 1,1 & 0,2 & 0,2 & 0,7 & 7,3 & 0,1 & 0,3 & 0,1 & 0,1 & 5,3 & 0 & 16,8 & $\frac{1.1}{16,0}$ & \begin{tabular}{|l|}
14,7 \\
\end{tabular} & 7,5 \\
\hline
\end{tabular}


ANEXO XIII- Tabela 9- Resultados de quantificação de minerais pesados $(\mathrm{d}>2,85)$ ao microscópio petrográfico na classe areia muito fina: MV2

\begin{tabular}{|c|c|c|c|c|c|c|c|c|c|c|c|c|c|c|c|c|c|c|c|c|c|c|c|c|c|}
\hline \multirow[t]{2}{*}{$\begin{array}{l}\text { CÓDIGO DA } \\
\text { AMOSTRA }\end{array}$} & \multicolumn{4}{|c|}{$\begin{array}{l}\text { GRUPO DOS MINERAIS } \\
\text { OPACOS E SEMI-OPACOS } \\
\text { FREQUENNCIAS DE } \\
\text { CONTAGEM NO ENSAIO (\%) } \\
\end{array}$} & \multicolumn{17}{|c|}{$\begin{array}{l}\text { GRUPO DOS MINERAIS TRANSPARENTES NÄO MICACEOS: } \\
\text { FREQUENCIAS DE CONTAGEM NO GRUPO ( } \%)\end{array}$} & \multirow{2}{*}{\begin{tabular}{|c} 
TOTAL \\
NO \\
ENSAIO \\
\end{tabular}} & \multicolumn{3}{|c|}{$\begin{array}{l}\text { INDICES DE } \\
\text { MATURIDADE } \\
\text { QUIMICA }\end{array}$} \\
\hline & OPAC & LEUC & LIMO & TOTAL & ZIRC & TURM & RUTI & ANAT & EPID & $\mathrm{ZOIS}$ & APAT & CHA & TITAT & SILL & ANN & & RAN & ज1 & TREM & IALTE & OTAL & & \begin{tabular}{|l|} 
ZZTR \\
\end{tabular} & IMET & IINS \\
\hline 5 & 16,0 & 4,0 & 3,0 & 23,0 & 77,1 & 0,0 & 0,9 & 0,9 & 14,7 & 0,0 & 0,0 & 0,0 & 0,0 & 2,8 & 0,9 & 0,0 & 0,0 & 0,9 & 0,9 & 0,9 & 100 & 79 & 78,7 & 18,5 & 2,8 \\
\hline 10 & 12,0 & 12,0 & 1,0 & 25,0 & 81,3 & 0,0 & 0,0 & 0,0 & 8,1 & 0,0 & 0,0 & 0,0 & 0,8 & 7,3 & 0,0 & 0,0 & 0,8 & 0,0 & 0,0 & 1,6 & 100 & 80 & 81,3 & 17,1 & 1,6 \\
\hline 15 & 70,0 & 5,0 & 1,0 & 76,0 & 61,5 & 0,0 & 0,0 & 0,0 & 7,7 & 0,0 & 0,0 & 0,0 & 7,7 & 15,4 & 0,0 & 0,0 & 0,0 & 0,0 & 0,0 & 7,7 & 100 & 21 & 61,5 & 30,8 & 7,7 \\
\hline 20 & & & & & & & & & & & & & & & & & & & & & & & & & \\
\hline 25 & 23,0 & 12,0 & 0,0 & 35,0 & 73,9 & 0,0 & 0,9 & 0,0 & 17,1 & 0,0 & 0,0 & 0,0 & 1,8 & 4,5 & 0,0 & 0,0 & 0,9 & 0,9 & 0,0 & 0,0 & 100 & 69 & \begin{tabular}{|l|l|} 
\\
\end{tabular} & 24,3 & 0,9 \\
\hline 30 & 8,0 & 0,0 & 0,0 & 8,0 & 76,2 & 0,0 & 0,0 & 0,0 & 14,3 & 0,0 & 0,0 & 0,0 & 0,0 & 9,5 & 0,0 & 0,0 & 0,0 & 0,0 & 0,0 & 0,0 & 100 & 92 & 76,2 & 23,8 & 0,0 \\
\hline 35 & 6,0 & 13,0 & 1,0 & 20,0 & 72,1 & 0,0 & \begin{tabular}{|c|}
0,0 \\
\end{tabular} & 0,0 & 15,5 & 0,0 & 0,0 & 0,0 & 1,6 & 4,7 & 0,0 & 0,0 & 0,0 & 5,4 & 0,0 & 0,8 & 100 & 85 & 72,1 & \begin{tabular}{|l|}
21,7 \\
\end{tabular} & 6,2 \\
\hline 40 & 5,0 & 4,0 & 0,0 & 9,0 & 87,1 & 0,0 & 4,0 & 0,0 & 5,6 & 0,0 & 0,0 & 0,0 & 0,8 & 0,8 & 0,0 & 0,0 & 0,0 & 0,8 & 0,0 & 0,8 & 100 & 92 & 91,1 & 7,3 & 1,6 \\
\hline 45 & 5,0 & 16,0 & 1,0 & 22,0 & 79,8 & 0,0 & \begin{tabular}{|l|}
0,0 \\
\end{tabular} & 0,0 & 10,9 & 0,0 & 0,0 & \begin{tabular}{|l|}
0,0 \\
\end{tabular} & 2,3 & 3,1 & 0,0 & 0,0 & 0,0 & 0,0 & 0,0 & 3,9 & 100 & 84 & 79,8 & 16,3 & 3,9 \\
\hline 50 & 46,0 & 4,0 & 0,0 & 50,0 & 78,0 & 0,0 & 0,0 & 0,0 & 14,0 & 0,0 & 0,0 & \begin{tabular}{|l|}
0,0 \\
\end{tabular} & 2,0 & 0,0 & 0,0 & 0,0 & 2,0 & 2,0 & 0,0 & 2,0 & 100 & 50 & 78,0 & 18,0 & 4,0 \\
\hline 55 & 2,0 & 2,0 & 0,0 & 4,0 & 83,6 & 0,0 & 0,0 & 0,0 & 3,6 & 0,0 & 0,0 & 0,0 & 0,9 & 10,0 & 0,0 & 0,0 & 0,0 & 0,0 & 0,0 & 1,8 & 100 & 96 & \begin{tabular}{|l|}
83,6 \\
\end{tabular} & \begin{tabular}{|l|}
14,5 \\
\end{tabular} & 1,8 \\
\hline 60 & 35,0 & 12,0 & 1,0 & 48,0 & 82,9 & 0,0 & 0,0 & 0,0 & 10,8 & 0,0 & 0,0 & \begin{tabular}{|l|}
0,0 \\
\end{tabular} & 1,8 & 2,7 & 0,0 & 0,0 & 0,9 & 0,0 & 0,0 & 0,9 & 100 & 58 & 82,9 & 16,2 & 0,9 \\
\hline 65 & 2,0 & 0,0 & 0,0 & 2,0 & 92,4 & 0,0 & 0,0 & 0,0 & 4,8 & 0,0 & 0,0 & \begin{tabular}{|l|}
0,0 \\
\end{tabular} & 0,0 & 2,9 & 0,0 & 0,0 & 0,0 & 0,0 & 0,0 & 0,0 & 100 & 98 & 92,4 & 7,6 & 0,0 \\
\hline 70 & 2,0 & 5,0 & 0,0 & 7,0 & 90,3 & 0,0 & 0,0 & 0,0 & 1,0 & 0,0 & 0,0 & \begin{tabular}{|l|}
0,0 \\
\end{tabular} & 2,9 & 4,9 & 0,0 & 0,0 & 0,0 & 1,0 & 0,0 & 0,0 & 100 & 93 & 90,3 & 8,7 & 1,0 \\
\hline 75 & 2,0 & 2,0 & \begin{tabular}{|l|}
0,0 \\
\end{tabular} & 4,0 & 95,5 & 0,0 & 1,8 & 0,0 & 0,9 & 0,0 & 0,0 & \begin{tabular}{|l|}
0,0 \\
\end{tabular} & 0,0 & 0,9 & 0,0 & 0,0 & 0,0 & 0,0 & 0,0 & 0,9 & 100 & 96 & \begin{tabular}{|l|}
97,3 \\
\end{tabular} & 1,8 & 0,9 \\
\hline 80 & 2,0 & 3,0 & 1,0 & 6,0 & 91,4 & 0,7 & 1,4 & 0,0 & 0,7 & 0,0 & 0,0 & \begin{tabular}{|l|}
0,0 \\
\end{tabular} & 0,7 & 2,1 & 0,0 & 0,0 & 0,0 & 0,7 & 0,0 & 2,1 & 100 & 95 & \begin{tabular}{|c|}
93,6 \\
\end{tabular} & 3,6 & 2,9 \\
\hline 85 & 1,0 & 12,0 & 0,0 & 13,0 & 73,3 & 0,0 & 0,0 & 0,8 & 18,3 & 0,0 & 0,8 & 0,0 & 1,7 & 3,3 & 0,0 & 0,0 & 0,0 & 0,0 & 0,0 & 1,7 & 100 & 90 & \begin{tabular}{|l|l}
73,9 \\
\end{tabular} & \begin{tabular}{|l|l}
24,4 \\
\end{tabular} & 1,7 \\
\hline 90 & & & & & & & & & & & & & & & & & & & & & & & & & \\
\hline 95 & 2,0 & 14,0 & 1,0 & 17,0 & 70,9 & 0,9 & 0,9 & 0,0 & 6,8 & 0,0 & 0,0 & 0,0 & 3,4 & \begin{tabular}{|l|}
11,1 \\
\end{tabular} & 0,0 & 0,0 & 0,0 & 0,9 & 0,0 & 5,1 & 100 & 87 & 72,6 & 21,4 & 6,0 \\
\hline 100 & 1,0 & 1,0 & \begin{tabular}{|l|}
0,0 \\
\end{tabular} & 2,0 & 86,9 & 0,0 & 0,8 & 0,0 & 4,1 & 0,0 & \begin{tabular}{|l|}
0,0 \\
\end{tabular} & \begin{tabular}{|l|}
0,8 \\
\end{tabular} & 2,5 & 2,5 & 0,0 & 0,0 & 0,0 & 0,8 & 0,0 & 1,6 & 100 & 98 & 87,7 & 9,8 & 2,5 \\
\hline 105 & 7,0 & 20,0 & 1,0 & 28,0 & \begin{tabular}{|l}
73,8 \\
\end{tabular} & 1,0 & 1,0 & 0,0 & 8,7 & 0,0 & 0,0 & 1,0 & 3,9 & 6,8 & 0,0 & 0,0 & 1,0 & 1,0 & 0,0 & 1,9 & 100 & 77 & 75,7 & 21,4 & 2,9 \\
\hline 110 & 1,0 & 7,0 & 3,0 & 11,0 & 13,4 & 0,7 & \begin{tabular}{|l|}
0,0 \\
\end{tabular} & 0,0 & 83,2 & 0,0 & 0,0 & 0,0 & 0,0 & 0,7 & 0,0 & 0,0 & 0 & 0 & 0 & 1,3 & 100 & 93 & 14,1 & \begin{tabular}{|l|}
83,9 \\
\end{tabular} & 2,0 \\
\hline 115 & 4,0 & 14,0 & \begin{tabular}{|l|}
3,0 \\
\end{tabular} & 21,0 & 10,4 & 0,3 & 0,0 & 0,0 & \begin{tabular}{|l}
71,8 \\
\end{tabular} & 0,0 & \begin{tabular}{|l|l}
0,0 \\
\end{tabular} & \begin{tabular}{|l|}
0,0 \\
\end{tabular} & 0,3 & 0,3 & 0,0 & $0,0,0$ & 0,0 & 5,5 & 0,0 & 11,4 & 100 & 91 & 10,7 & \begin{tabular}{|l|}
72,4 \\
\end{tabular} & 16,9 \\
\hline 120 & 5,0 & 10,0 & 1,0 & 16,0 & 14,2 & 0,6 & 0,6 & 0,0 & 71,6 & 0,0 & 0,0 & \begin{tabular}{|l|}
0,0 \\
\end{tabular} & 0,0 & 0,6 & 0, & 0,0 & 0,0 & 4,7 & 0,0 & 7,7 & 100 & 89 & 15,4 & 72,2 & 12,4 \\
\hline 125 & 4,0 & 8,0 & 4,0 & 16,0 & 22,3 & 0,7 & 0,4 & 0,0 & 73,0 & 0,0 & 0,0 & \begin{tabular}{|l|}
0,0 \\
\end{tabular} & 0,4 & 0,4 & 0,0 & 0,0 & 0,0 & 1,8 & 0,0 & 1,1 & 100 & 92 & 23,4 & 73,7 & 2,9 \\
\hline 130 & 2,0 & 6,0 & 1,0 & 9,0 & \begin{tabular}{|l}
21,2 \\
\end{tabular} & 2,1 & 0,7 & 0,0 & 65,8 & 0,0 & \begin{tabular}{|l|}
0,0 \\
\end{tabular} & \begin{tabular}{|l|}
0,0 \\
\end{tabular} & 0,7 & 0,7 & 0, & 0,0 & 0,7 & 2,1 & 0 & 6,2 & 100 & 94 & 24,0 & \begin{tabular}{|l|}
67,8 \\
\end{tabular} & 8,2 \\
\hline 135 & 2,0 & 17,0 & 5,0 & 24,0 & 13,1 & 1,5 & \begin{tabular}{|l|}
0,7 \\
\end{tabular} & 0,0 & \begin{tabular}{|l|}
75,2 \\
\end{tabular} & 0,7 & 0,0 & 0,0 & 0,7 & 1,5 & 0,0 & 0,0 & 0 & 2,9 & 0, & 3,6 & 100 & 84 & 15,3 & \begin{tabular}{|l|}
78,1 \\
\end{tabular} & 6,6 \\
\hline 140 & 2,0 & 1,0 & 1,0 & 4,0 & 12,5 & 1,1 & 0,0 & 0,0 & 74,4 & 00 & 0,0 & 0,0 & 0,6 & 0,6 & 0 & 0,0 & 0 & 8 & 0 & 2,8 & 100 & 97 & 13,6 & \begin{tabular}{|l|}
75,6 \\
\end{tabular} & 10,8 \\
\hline 145 & 3,0 & 4,0 & \begin{tabular}{|l|}
3,0 \\
\end{tabular} & 10,0 & 10,0 & 0,4 & 0,8 & 0,0 & 82,4 & 0,0 & 0,0 & 0,0 & 0,4 & 0,8 & 0,0 & 0,0 & 0,0 & 3,8 & 0,0 & 1,3 & 100 & 94 & 11,3 & \begin{tabular}{|l|}
83,7 \\
\end{tabular} & 5,0 \\
\hline 150 & 1,0 & 6,0 & \begin{tabular}{|l|}
0,0 \\
\end{tabular} & 7,0 & \begin{tabular}{|l|l}
24,3 \\
\end{tabular} & 2,6 & 0,7 & 0,0 & \begin{tabular}{|l|}
65,8 \\
\end{tabular} & 0,0 & 0,0 & 0,0 & 1,3 & 1,3 & 0,0 & 0,0 & 0,0 & 0,7 & 0, & 3,3 & 100 & 95 & 27,6 & \begin{tabular}{|l|}
68,4 \\
\end{tabular} & 3,9 \\
\hline 155 & 1,0 & 12,0 & 2,0 & 15,0 & \begin{tabular}{|l}
38,7 \\
\end{tabular} & 3,2 & 0,8 & 0,0 & \begin{tabular}{|l|}
41,1 \\
\end{tabular} & 0,0 & 0,0 & \begin{tabular}{|l|l|}
0,0 \\
\end{tabular} & 0,8 & 1,6 & 0 & 0 & 0 & 3 & 0 & 10,5 & 100 & 89 & 42,7 & \begin{tabular}{|l|}
43,5 \\
\end{tabular} & 13,7 \\
\hline 160 & 8,0 & 3,0 & \begin{tabular}{|l|}
2,0 \\
\end{tabular} & 13,0 & \begin{tabular}{|l}
23,8 \\
\end{tabular} & 1,6 & 0,0 & 0,0 & \begin{tabular}{|l|}
63 \\
\end{tabular} & 0,0 & \begin{tabular}{|l|}
0,0 \\
\end{tabular} & \begin{tabular}{|l|}
0,0 \\
\end{tabular} & 0,8 & 0,8 & 0, & 0,0 & 0 & 6,6 & 0 & 3,3 & 100 & 88 & 25,4 & \begin{tabular}{|l|l}
64,8 \\
\end{tabular} & 9,8 \\
\hline 165 & 7,0 & 10,0 & 5,0 & 22,0 & 48,5 & 1,5 & 0,0 & 0,0 & 40,0 & 0,0 & 0,0 & 0,0 & 0,0 & 0,8 & 0,0 & 0,0 & 0,0 & 4,6 & 0, & 4,6 & 100 & 83 & 50,0 & 40,8 & 9,2 \\
\hline 170 & 20,0 & 10,0 & 3,0 & 33,0 & 28,1 & 2,4 & 0,0 & 0,0 & 61,7 & 00 & \begin{tabular}{|l|}
0,6 \\
\end{tabular} & 0,0 & 0,6 & 0,0 & 0, & 0 & 0 & 5,4 & 0, & 1,2 & 100 & 74 & 30,5 & 62,9 & 6,6 \\
\hline 175 & 1,0 & 4,0 & 2,0 & 7,0 & 18,0 & 3,8 & 0,0 & 0,0 & 71,4 & 0,0 & 0,0 & \begin{tabular}{|l|}
0,0 \\
\end{tabular} & 0,8 & 0,8 & 0,0 & 0,0 & 0 & 2,3 & 0,0 & 3,0 & 100 & 95 & 21,8 & 72,9 & 5,3 \\
\hline 180 & 5,0 & 1,0 & 1,0 & 7,0 & 22,9 & 3,1 & 0,0 & 0,0 & 64,8 & 0,0 & 0,0 & 0,0 & 0,9 & 0,9 & 0,0 & 0,0 & 0 & - & 0 & 2,2 & 100 & 94 & 26,0 & 67,0 & 7,0 \\
\hline 185 & 4,0 & 6,0 & 1,0 & 11,0 & \begin{tabular}{|l}
26,7 \\
\end{tabular} & 1,6 & 0,0 & 0,0 & \begin{tabular}{|l|}
63,1 \\
\end{tabular} & 0,0 & \begin{tabular}{|l|}
0,5 \\
\end{tabular} & \begin{tabular}{|l|}
0,0 \\
\end{tabular} & 1,1 & 0,5 & 0,0 & 0,0 & 0, & 4,3 & 0,0 & 2,1 & 100 & 93 & 28,3 & \begin{tabular}{|l}
65,2 \\
\end{tabular} & 6,4 \\
\hline 190 & 1,0 & 9,0 & 3,0 & 13,0 & 30,8 & 2,5 & 0,0 & 0,0 & 59,7 & 0,0 & 0,0 & 0,0 & 0,6 & 0,3 & 0,0 & 0,0 & 0 & 4 & 0,0 & 1,3 & 100 & 95 & 33,3 & 60,6 & 6,0 \\
\hline 195 & 1,0 & 10,0 & 2,0 & 13,0 & 33,9 & 1,8 & 0,0 & 0,0 & 51,3 & 0,0 & 0,0 & 0,0 & 2,2 & 0,9 & 0, & 0,0 & 0 & 7,6 & 0,0 & 2,2 & 100 & 94 & 35,7 & 54,5 & 9,8 \\
\hline 200 & 1,0 & 3,0 & 1,0 & 5,0 & 27,8 & 1,3 & 0,6 & 0,0 & 60,8 & 0,0 & 0,0 & 0,0 & 0,6 & 1,3 & 0, & 0,0 & 0 & 3,8 & 0,0 & 3,8 & 100 & 97 & \begin{tabular}{|l|}
29,7 \\
\end{tabular} & 62,7 & 7,6 \\
\hline 205 & 1,0 & 0,0 & \begin{tabular}{|l|}
1,0 \\
\end{tabular} & 2,0 & \begin{tabular}{|l}
30,0 \\
\end{tabular} & 2,7 & 0,0 & 0,0 & \begin{tabular}{|l}
61,3 \\
\end{tabular} & 0,0 & \begin{tabular}{|l|}
0,7 \\
\end{tabular} & \begin{tabular}{|l|}
0,0 \\
\end{tabular} & 1,3 & 0,7 & 0,0 & 0,0 & \begin{tabular}{|l|}
0,0 \\
\end{tabular} & 1,3 & 0,0 & 2,0 & 100 & 98 & 32,7 & \begin{tabular}{|l|l|}
64,0 \\
\end{tabular} & 3,3 \\
\hline 210 & 1,0 & 6,0 & 1,0 & 8,0 & \begin{tabular}{|l}
49,7 \\
\end{tabular} & 1,1 & 0,0 & 0,0 & \begin{tabular}{|l|}
43,4 \\
\end{tabular} & 0,0 & \begin{tabular}{|l|}
0,0 \\
\end{tabular} & 0,0 & 0,6 & 0,6 & 0,0 & 1,1 & 0,0 & 2,3 & 0,0 & 1,1 & 100 & 95 & 50,9 & \begin{tabular}{|l|}
45,7 \\
\end{tabular} & 3,4 \\
\hline MÁXIM & 70,0 & 20,0 & 5,0 & 76,0 & \begin{tabular}{|l}
95,5 \\
\end{tabular} & 3,8 & 4,0 & 0,9 & \begin{tabular}{|l|}
83,2 \\
\end{tabular} & \begin{tabular}{l|l}
0,7 \\
\end{tabular} & \begin{tabular}{|l|}
0,8 \\
\end{tabular} & 1,0 & 7,7 & \begin{tabular}{|l|}
15,4 \\
\end{tabular} & 0, & 1,1 & 2,0 & 8,0 & 0,9 & 11,4 & 100 & 98,3 & 97,3 & \begin{tabular}{|l|l|}
83,9 \\
\end{tabular} & 169 \\
\hline MíNIMO & 1,0 & 0,0 & 0,0 & 2,0 & \begin{tabular}{|l}
10,0 \\
\end{tabular} & 0,0 & 0,0 & 0,0 & 0,7 & 0,0 & 0,0 & 0,0 & 0,0 & \begin{tabular}{|l|}
0,0 \\
\end{tabular} & 0 & 0,0 & 0,0 & 0,0 & 0,0 & 0,0 & 100 & 20,5 & \begin{tabular}{|l|}
10,7 \\
\end{tabular} & \begin{tabular}{|l|l|}
1,8 \\
\end{tabular} & 0,0 \\
\hline MÉDIA & 8,1 & 7,2 & 1,4 & 16,7 & \begin{tabular}{|l|}
51,2 \\
\end{tabular} & 1,0 & 0,4 & 0,0 & 37,8 & 0,0 & \begin{tabular}{|l|}
0,1 \\
\end{tabular} & 0,0 & 1,2 & 2,8 & 0,0 & 0,0 & \begin{tabular}{|l|}
0,2 \\
\end{tabular} & 2,4 & 0,0 & 2,7 & 100 & 86,7 & \begin{tabular}{|l|}
52,7 \\
\end{tabular} & \begin{tabular}{|l|l}
42,2 \\
\end{tabular} & 5,2 \\
\hline DESV.PADRÃO & 13,6 & 5,1 & 1,4 & 14,8 & 29,5 & 1,1 & 0,7 & 0,2 & 29,1 & 0,1 & \begin{tabular}{|l|}
0,2 \\
\end{tabular} & 0,2 & 1,4 & 3,5 & 0,1 & 0,2 & 0,4 & 2,3 & 0,1 & 2,6 & 0 & 14,8 & 29,0 & 26,7 & 3,9 \\
\hline
\end{tabular}

